UNIVERSIDADE DE SÃO PAULO

FACULDADE DE ECONOMIA, ADMINISTRAÇÃO E CONTABILIDADE DEPARTAMENTO DE ADMINISTRAÇÃO PROGRAMA DE PÓS-GRADUAÇÃO EM ADMINISTRAÇÃO

MÉTRICAS DE AVALIAÇÃO DE COMUNICAÇÃO DE MARKETING OFFLINE E ONLINE: UM ESTUDO SOBRE O SETOR DE BANCOS

Valéria Leal Marinho de Andrade Freundt

Orientador: Prof. Dr. Edson Crescitelli 
Prof. Dr. João Grandino Rodas

Reitor da Universidade de São Paulo

Prof. Dr. Reinaldo Guerreiro

Diretor da Faculdade de Economia, Administração e Contabilidade

Prof. Dr. Adalberto Américo Fishmann

Chefe de Departamento de Administração

Prof. Dr. Lindolfo Galvão de Albuquerque

Coordenador do Programa de Pós-Graduação em Adminstração 
Valéria Leal Marinho de Andrade Freundt

\section{MÉTRICAS DE AVALIAÇÃO DE COMUNICAÇÃO DE MARKETING OFFLINE E ONLINE: UM ESTUDO SOBRE O SETOR DE BANCOS}

Tese de Doutorado apresentada ao Departamento de Administração da Faculdade de Economia, Administração e Contabilidade da Universidade de São Paulo, como requisito para obtenção do título de Doutor em Ciências.

Orientador: Prof. Dr. Edson Crescitelli

\section{Versão Corrigida}

(versão corrigida disponível na Faculdade de Economia, Administração e Contabilidade) 
FICHA CATALOGRÁFICA

Elaborada pela Seção de Processamento Técnico do SBD/FEA/USP

Freundt, Valéria Leal Marinho de Andrade

Métricas de avaliação de comunicação de marketing offline e online :

um estudo sobre o setor de bancos / Valéria Leal Marinho de Andrade

Freundt. -- São Paulo, 2012.

$237 \mathrm{p}$.

Tese (Doutorado) - Universidade de São Paulo, 2012.

Orientador: Edson Crescitelli.

1. Comunicação em marketing 2. Marketing 3. Marketing on-line 4. Métricas de comunicação 5. Métricas de marketing 6. Bancos I. Universidade de São Paulo. Faculdade de Economia, Administração e Contabilidade II. Título.

CDD -658.8 


\section{FOLHA DE APROVAÇÃO}

Valéria Leal Marinho de Andrade Freundt

MÉTRICAS DE AVALIAÇÃO DE COMUNICAÇÃO DE MARKETING OFFLINE E ONLINE: UM ESTUDO SOBRE O SETOR DE BANCOS

Tese de Doutorado apresentada ao Departamento de Administração da Faculdade de Economia, Administração e Contabilidade da Universidade de São Paulo, como requisito para obtenção do título de Doutor em Ciências.

Área: Comunicação de Marketing

Banca Examinadora:

Prof. Dr. Edson Crescitelli

Orientador

Prof. Dr.

Profa Dra.

Prof Dr.

Prof Dr. 
"Quando o discípulo estiver pronto, o mestre aparecerá". Provérbio budista 
A Bernd, meu amor, companheiro e melhor amigo, por tudo.

À Clara, minha mãe, pela inspiração em tornar-me professora e por estar aqui neste momento.

A Luciano, meu pai, in memoriam, mas sempre presente. 


\section{AGRADECIMENTOS}

A Deus por ter me dado luz e força para concluir este ciclo e superar as adversidades. Ao professor, orientador Dr. Edson Crescitelli pelo apoio, dedicação e inestimável contribuição e incentivo para a realização desta tese.

Ao professor e membro da banca Dr. Marcos Campomar, por ter compartilhado conhecimento, inspiração e experiência profissional e de como extrair o melhor da vida.

À professora Thelma Rocha, membro da banca, pelas suas valiosas contribuições, aprimorada revisão e verdadeira disposição para ajudar.

Aos professores Ana Ikeda, Geraldo Toledo e José Affonso Mazzon, pelos conhecimentos compartilhados em suas aulas.

À minha irmã Aracy que incentivou este projeto e deu-me todo o apoio emocional nos momentos de necessidade.

Aos meus queridos filhos Stephan e Thomas que, mesmo nos momentos de privação de atenção, entenderam a importância deste projeto.

Aos amigos Joanília Cia, Ricardo Machado e Luciano Crocco, pela amizade e pelo incentivo, antes e durante o doutorado, assim como pelo apoio para a realização das entrevistas e elaboração deste estudo.

À amiga Carmen Costa pela inestimável ajuda com a revisão e apoio em momentos críticos da realização da tese.

A Rogério Barbosa por compartilhar seu conhecimento e experiência com a técnica de análise de conteúdo.

A todos os amigos que me ajudaram na marcação as entrevistas: André Lóes, Cândida Sevilhano, Deli Brandão e Otto Nogami.

Aos funcionários das secretarias e biblioteca pela força e apoio.

Por último, mas não menos importante, a todos os executivos e profissionais que concordaram em participar da pesquisa e contribuíram para o entendimento do tema. 


\section{RESUMO}

O presente estudo tem como objetivos contribuir para um melhor entendimento de como as empresas lidam com a diversidade de decisões de comunicação de marketing offline e online e de métricas de avaliação destes investimentos e propor um modelo de adoção de métricas para a avaliação dos resultados de ações de comunicação offline e online.

Para isso foi realizado um estudo exploratório dividido em duas etapas. A primeira parte foi constituída de revisão de literatura sobre as ferramentas de comunicação de marketing offline e online, métricas e métricas das ações de comunicação offline e online. A segunda etapa foi uma pesquisa empírica exploratória baseada em entrevistas em profundidade com profissionais de comunicação de marketing representantes do Banco do Brasil, Banco Votorantim, Bradesco, Citibank, Itaú, HSBC e Santander.

O procedimento analítico adotado foi análise de conteúdo. Foram analisadas as ações de comunicação offline e online mais significativas para a amostra e as métricas adotadas para sua avaliação. Concluiu-se haver uma diversidade de caminhos para a avaliação das ações de comunicação, desde a adoção de métricas únicas como avaliação das marcas e índices de satisfação ou de relacionamento com clientes, até casos de empresas que perseguem métricas de ROI para cada ação offline e online isolada.

Foi proposto um modelo de adoção de métricas de avaliação dos resultados das ações de comunicação offline e online apontadas pela amostra como as mais importantes. Neste modelo, estas ações e suas respectivas métricas foram organizadas segundo três públicosalvo: a grande massa, segmentos específicos e indivíduos.

Palavras-chave: Marketing, planejamento de comunicação e métricas. 


\begin{abstract}
The present study aims to contribute to a better understanding of how companies deal with the diversity of offline and online marketing communication decisions, a large range of metrics to evaluate these investments and also propose a model of offline and online communication metrics.

In order to achieve that aim an exploratory study organized in two phases was conducted. The first phase encompassed a review of the literature related to offline and online communication tools, metrics and metrics of evaluation of offline and online communication tools. It was followed by an exploratory empirical research based on indepth interviews with marketing communication professionals representing Banco do Brasil, Banco Votorantim, Itaú, Bradesco, Citibank, HSBC and Santander.

The analytical procedure implemented was content analysis, which allowed analyzing the most significant offline and online communication tools mentioned by the sample and the metrics used to their evaluation. It was concluded that there is a variety of ways to evaluate communication tools, from the adoption of unique metrics such as brand evaluation, customer satisfaction indexes and customer relationship, to situations on which it is applied ROI metric for each offline and online communication tool.

It was proposed a model regarding metrics for evaluating offline and online communication tools considered most important by the professional interviewed. In this model, the communication tools and their metrics were organized according to three audiences: the great mass, specific segments and individuals.
\end{abstract}

Keywords: Marketing, marketing communication planning and metrics. 


\section{SUMÁRIO}

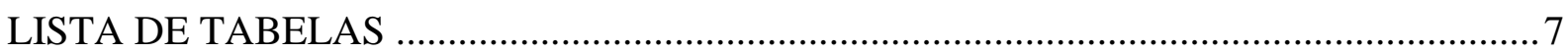

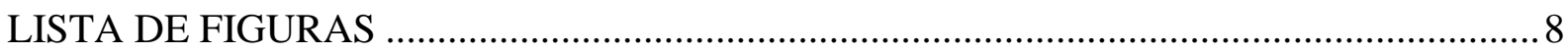

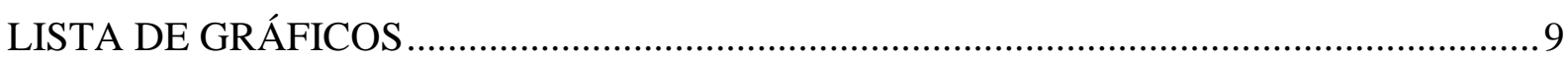

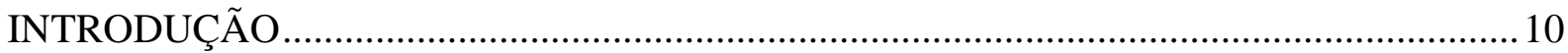

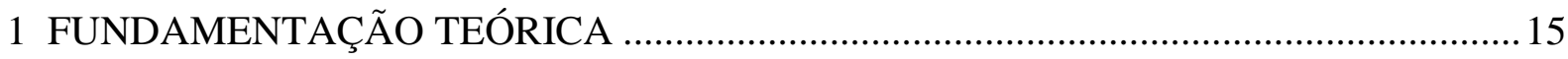

1.1 Comunicação de marketing ........................................................................... 15

1.1.1. Ferramentas do mix de comunicação de marketing offline e online .......................20

1.1.2 Comunicação integrada de marketing .............................................................. 78

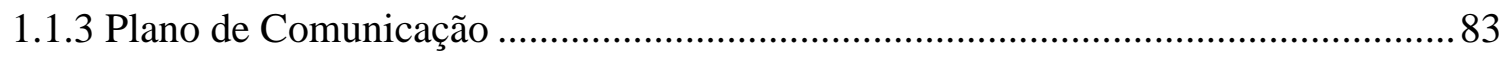

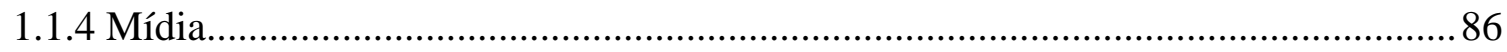

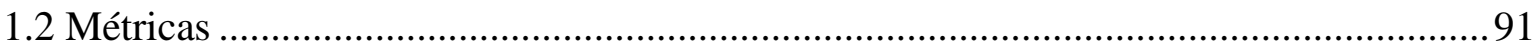

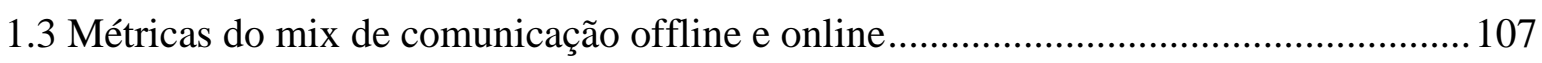

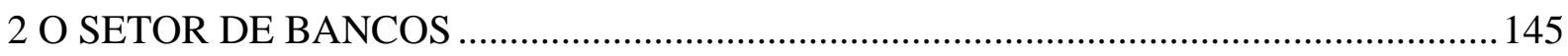

2.1 A importância da internet para o setor bancário no Brasil ........................................ 147

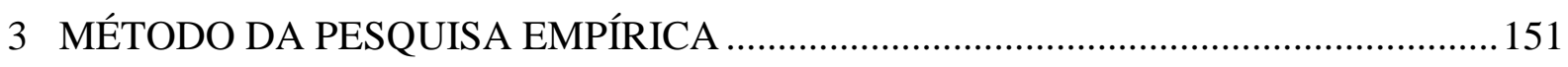

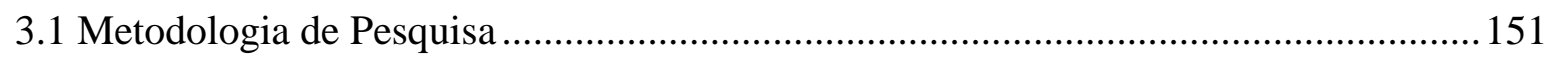

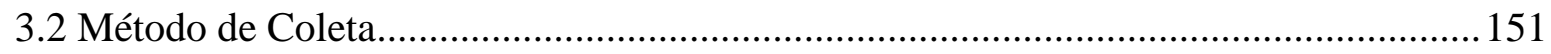

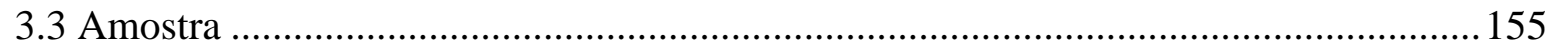

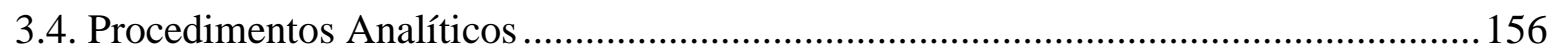

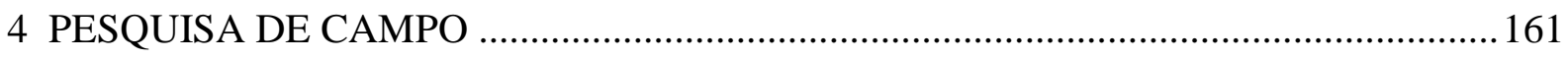

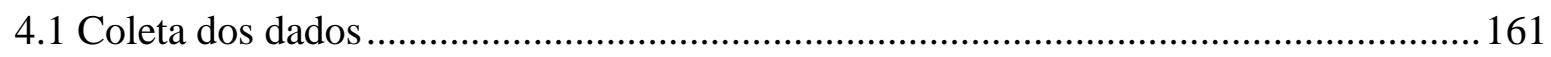

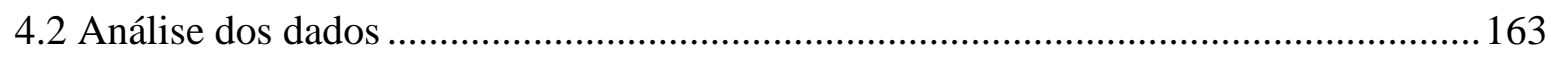

4.2.1 Ferramentas de comunicação offline e online mais significativas ........................ 164

4.2.2 Ferramentas de comunicação por mercado-alvo e objetivos.................................177

4.2.3 Métricas das ferramentas de comunicação offline e online mais significativas....178

4.2.4 Comparação de métricas de avaliação de ações de comunicação offline com ações online

4.2.5 Considerações sobre a adoção de métricas de avaliação dos investimentos em comunicação offline e online.

4.2.6 Modelo de adoção de métricas de avaliação dos resultados das ações de comunicação offline e online apontadas como as mais importantes ...............................198

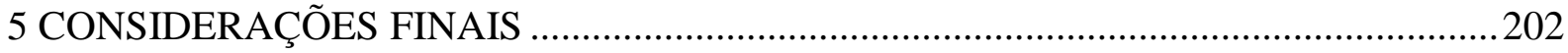




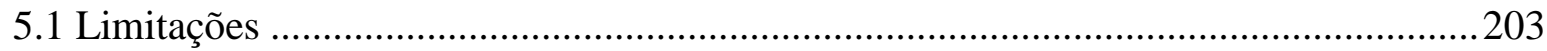

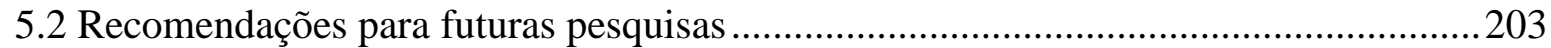

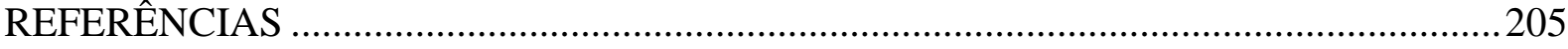

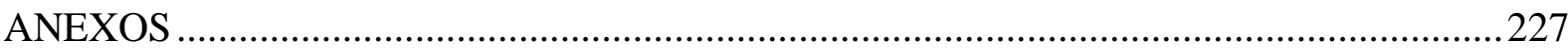




\section{LISTA DE ABREVIATURAS E SIGLAS}

ABA - Associação Brasileira de Anunciantes

ABEMD - Associação Brasileira de Marketing Direto

$\mathrm{ATL}-$ Above the line

AMA - American Marketing Association

ATM - Automated Teller Machine - caixas eletrônicos de autoatendimento

BB - Banco do Brasil

Bacen - Banco Central do Brasil

$\mathrm{BTL}-$ Below the line

BNH - Banco Nacional de Habitação

B2B - Business to Business - Negócios voltados para empresas

B2C - Business to Consumer - Negócios voltados para consumidores finais

CCBB - Centro Cultural Banco do Brasil

CEF - Caixa Econômica Federal

CGM - Consumer Generated Media

CIM - Comunicação Integrada de Marketing

CIM - Chartered Institute of Marketing

CME - Custo por mil exposições

CLV - Customer Life Value - Valor do Cliente no seu ciclo de vida

CoRM - Community Relationship Management

CPM - Custo por mil

CPR - Custo por Resposta

CPP - Custo por pedido

CPPP - Custo Permissível por pedido

CPV - Custo por venda

CRM - Customer Relationship Management - Gestão do relacionamento com clientes

CRV - Customer Referral Value - Valor das referências do cliente

DAGMAR - Defining Advertising Goals for Measured Advertising Response

DVR - Digital Video Recorder

EMIS - Emerging Markets Information Service

EVA - Economic Value Added

FEBRABAN - Federação Brasileira dos Bancos 
FGTS - Fundo de Garantia do Tempo de Serviço

GRP - Gross Rating Point

IBOPE - Instituto Brasileiro de Opinião Pública e Estatística

ITU - International Telecommunication Union

IVC - Instituto de Verificador de Circulação

KAM - Key Account Managers

KEY - Ketchum Effectiveness Yardstick

KPIs - Key Performance Indicators ou Indicadores-chave de desempenho

LTV - Lifetime Value do cliente, ou Valor do cliente ao longo do tempo

MSI - Marketing Science Institute

ODV - Oportunidades de Ver

ONGs - Organização Não Governamentais

OWOM - Online Word-of-Mouth ou Online Word-of-Mouse

PAA - Postos Avançados de Atendimento

PAB - Postos de Atendimento Bancário

PACRE - Postos Avançados de Crédito Rural

PAC - Postos de Atendimento Cooperativo

PAM - Postos de Atendimento ao Microcrédito

PAP - Postos de Arrecadação e Pagamentos

PAR - Programa de Arrendamento Residencial

PCO - Postos de Compra de Ouro

PDC - Processo de Decisão de Compra

PDV - Ponto de Venda

PF - Pessoa Física

PJ - Pessoa Jurídica

PIMS - Profit Impact of Market Strategies

PIS - Programa de Integração Social

POPAI - Point-Of-Purchase Advertising International

ROI - Return on Investiments

RP - Relações Públicas

RPM - Relações Públicas aplicadas ao Marketing

SBPE - Sistema Brasileiro de Poupança e Empréstimo

SFH - Sistema Financeiro de Habitação

TGI - Target Group Index 
TRP - Target Rating Point

VBC - Value-based communication

VDC - Valor de Duração do Cliente

VPL - Valor Presente Líquido

WOMMA - Word of Mouth Marketing Association

Y\&R - Young and Rubicam 


\section{LISTA DE QUADROS}

Quadro 1 Ações de comunicação de marketing..................................................... 78

Quadro 2 Definições para a CIM..................................................................... 80

Quadro 3 Histórico das dimensões de métricas de marketing.................................. 99

Quadro 4 Feramentas do mix de comunicação, objetivos e dificuldade de 109

Quadro 5 Avaliação de ações de RP.............................................................. 113

Quadro 6 Métricas de rentabilidade do cliente...................................................... 135

Quadro 7 Métricas do mix de comunicação offline e online ................................... 140

Quadro 8 $\begin{array}{ll}\text { Diversidade e intensidade de uso das ferramentas de comunicação } \\ \text { offline e online pelos bancos brasileiros }\end{array}$

Quadro 9 Domínios de aplicação da análise de conteúdo...................................... 159

Quadro 10 Dados referenciais das entrevistas ....................................................... 162 


\section{LISTA DE TABELAS}

Tabela 1 Bancos Patrocinadores Culturais - Valores relativos às Leis Rouanet $\mathrm{e}$ Audiovisual 2006-2008 (em mil R\$)

Tabela 2 Participação das mídias (\%) no faturamento do mercado de comunicação (período) 2006 -2010

Tabela 3 Efetividade de diferentes mídias de marketing direto nos EUA -2010.....

Tabela 4 Categorias consideradas na análise de conteúdo das ferramentas do mix de comunicação

Tabela 5 Atuação dos bancos nas mídias sociais.

Tabela 6 Métricas adotadas para ações de comunicação offline e online e categorias de análise de conteúdo.

Tabela 7 Métricas de avaliação de propaganda.

Tabela 8 Métricas de avaliação de marketing de relacionamento... 183

Tabela 9 Métricas de avaliação de patrocínio. 185

Tabela 10 Métricas de avaliação de marketing direto 187

Tabela 11 Métricas de avaliação de mídias sociais 


\section{LISTA DE FIGURAS}

Figura 1 Modelo do comportamento do consumidor.............................................. 16

Figura 2 Fluxo de Comunicação de Marketing - forma e meio.............................. 19

Figura 3 Mix de comunicação de marketing.......................................................... 21

Figura 4 Objetivos genéricos da propaganda..................................................... 25

Figura $5 \quad$ O patrocínio como construtor de marca................................................... 32

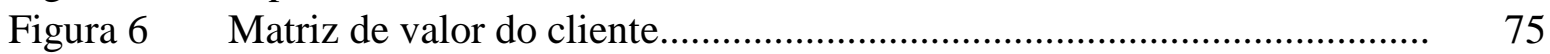

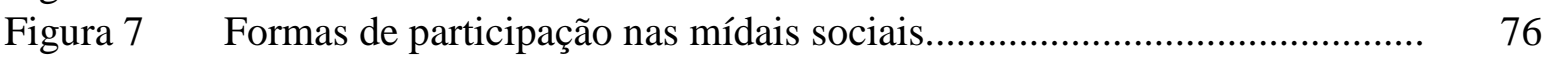

Figura $8 \quad$ Plano de Comunicação.................................................................... 84

Figura 9 O processo de decisão da comunicação de marketing............................... 85

Figura 10 Modelo de hierarquia de efeitos de Lavidge e Steiner............................. 102

Figura 11 Classificação de métricas por Farris et al ................................................ 103

Figura 12 Propaganda e pesquisa de propaganda aplicada ao modelo de hierarquia 110 de efeitos.

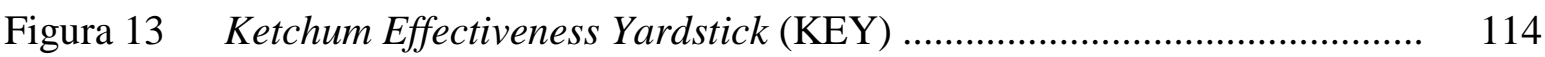

Figura $14 \quad$ O mapa do patrocínio.......................................................................... 116

Figura 15 Fluxo de visitas de um visitante identificado........................................ 128

Figura 16 Origem das visitas aos sites das três maiores instituições financeiras 132 2004-2011.

Figura 17 Estatísticas comportamentais disponíveis no YouTube............................. 133

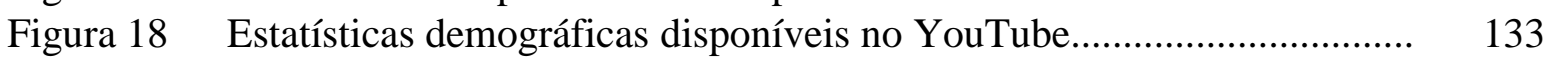

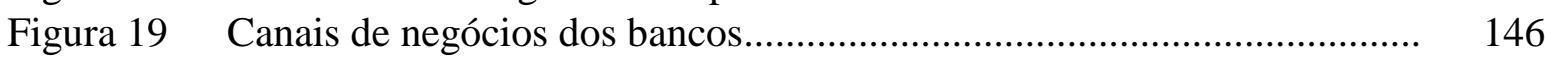

Figura 20 Processo de análise do conteúdo............................................................ 157

Figura 21 Ações de comunicação offline e online segundo mercados-alvo e objetivos....................................................................................... 177

Figura 22 Modelo de adoção de métricas de avaliação dos resultados das ações de comunicação offline e online mais importantes e suas respectivas métricas. 


\section{LISTA DE GRÁFICOS}

Gráfico 1 Ferramentas de promoção de vendas ao longo do ciclo de vida do produto.............................................................................................. 41

Gráfico 2 Facebook supera Orkut no Brasil - número de usuários (MM)................. 72

Gráfico 3 Penetração de mídia na população brasileira............................................... 90

Gráfico 4 Exemplo revalidação de cartões de crédito............................................. 121

Gráfico 5 Eficácia cumulativa de comerciais........................................................... 128

Gráfico 6 Visitas aos sites das três maiores instituições financeiras do Brasil 2004-2011 ......................................................................... 131 


\section{INTRODUÇÃO}

Mudanças, tanto de oferta, quanto de demanda por produtos e serviços vêm estimulando a intensificação do uso de métricas de avaliação dos resultados de investimentos em comunicação de marketing. Do lado da oferta, destacam-se o acirramento da concorrência, o surgimento de novas categorias e versões de produtos e a proliferação de marcas. Além disso, a ascensão e a consolidação da internet e de novas mídias que permitem o consumidor do século XXI estar conectado vêm trazendo mais complexidade às decisões de comunicação de marketing.

Na esfera da demanda, os consumidores, público-alvo dos esforços de comunicação de marketing, estão cada vez mais saturados pelo aumento da quantidade de informações e mídias vêm se tornando mais exigentes e críticos em relação às ações de comunicação e menos dispostos a dedicar atenção à enxurrada de informações à qual são expostos, mostrando-se menos suscetíveis aos apelos de persuasão para a compra.

$\mathrm{Na}$ era digital, as mídias que permitem acesso à internet surgem e se renovam aceleradamente, incluindo entre outros netbooks, smartphones e tablets. Em função destas novas mídias de acesso à dimensão online, o consumidor e as empresas vêm lidando também com diferentes formas de comunicação e relacionamento, tais como redes sociais, torpedos e e-mails.

A internet agilizou o processo de comunicação e permitiu uma nova forma de participação do consumidor neste processo. Enquanto as ações de comunicação de marketing offline caracterizavam-se por serem de mão única - anunciante para o consumidor, a comunicação de marketing online permite a comunicação em mão dupla, com interação. O consumidor passou a ter um papel mais ativo na comunicação de marketing (STEWART e PAVLOU, 2002, p. 376). Neste cenário de crescente complexidade na relação anunciante-consumidor, os profissionais de comunicação de marketing lidam com o desafio de inovar suas ações de comunicação a fim de atrair a disputada atenção deste consumidor, tanto na dimensão offline, quanto no crescente universo online. 
A fim de obter a atenção de seus clientes, despertar o interesse e desenvolver valor para suas marcas, as empresas investem cada vez mais na divulgação de suas ofertas. De acordo com projeções da Reuters (FALKE INFORMATION, 2011, p. 32) o investimento publicitário mundial deverá atingir cerca de meio trilhão de dólares em 2011 e deverá ampliar cerca de 5\% ao ano nos próximos anos. Este aumento será impulsionado, principalmente, pelos mercados em desenvolvimento e pela mídia digital. No Brasil os investimentos em comunicação de marketing também vêm crescendo. No período 2007/2008, houve um incremento de $12 \%$ nos investimentos desta natureza e, em 2010, o faturamento do mercado publicitário cresceu 17,7\% (BATOCHIO, 2011, p. 24).

O aumento e diversificação dos investimentos em comunicação offline e online é acompanhado por maior cobrança em relação aos resultados atingidos. A preocupação com o aumento de gastos e a busca da eficiência dos investimentos em comunicação é antiga e associada à procura de respostas a questões fundamentais, tais como "quanto investir em comunicação?", "qual o efeito associado ao investimento em comunicação sobre vendas?" e " qual o retorno que este investimento traz ao negócio? ". No intuito de aumentar a eficiência dos investimentos em comunicação de marketing, há alguns anos as empresas vêm dedicando esforços para integrarem seus gastos por meio da Comunicação Integrada de Marketing (CIM), que visa otimizar os diferentes gastos em comunicação (SCHULTZ et al, 1993; SHIMP, 2002, BELCH; BELCH, 2008).

Apesar de a CIM oferecer benefícios quanto à otimização dos investimentos em comunicação, sua adoção não é suficiente para garantir o melhor uso dos recursos. Emfunção disso, as empresas anunciantes vêm buscando melhorar sua capacidade de avaliação da eficácia dos investimentos em comunicação, por meio da utilização de métricas de avaliação dos resultados destes investimentos.

\section{O problema em estudo}

Os profissionais de comunicação de marketing lidam com uma diversidade de decisões de comunicação e de mídias com distintas características e potencial de impacto junto aos diferentes públicos - TV, rádio, revista, jornal, outdoor, internet, celulares, elevadores, encosto das poltronas de aviões e tantas outras. 
Tantas alternativas são acompanhadas por uma ampla diversidade de métricas de avaliação de resultados. Devido às particularidades das ações de comunicação offline e online e das mídias escolhidas para estas ações, as métricas também são, em sua grande maioria, específicas às decisões de comunicação das dimensões offline e online.

O meio acadêmico também dedica esforços a aprimorar o entendimento e a eficiência da mensuração dos resultados dos investimentos desta natureza. Farris et al (2007) propuseram que todo executivo deveria dominar 50 métricas essenciais de marketing, dentre as quais métricas de comunicação. Queiroz (2008, p. 18) identificou mais de 100 métricas de avaliação de resultados em estudo realizado no Brasil.

Alguns autores, no intuito de estruturar a avaliação dos resultados e suportar os profissionais de marketing na justificativa de seus investimentos, criaram ferramentas como o Modelo de Métricas de Marketing (MCDONALD; MOUCEY, 2011, p. 228) e a Metodologia ComValor (GUISSONI; NEVES, 2011, p. 18-19). Schultz e Schultz (2003, p. 269-276) propuseram dois modelos, um centrado no Customer Life Value (CLV) e outro focado no conceito de Brand Equity (SCHULTZ; SCHULTZ, 2003, p. 321-348).

Em decorrência do panorama apresentado, gerenciar as decisões de comunicação offline e online e escolher quais métricas adotar para a avaliação dessa variedade de investimentos tornaram-se um desafio para os profissionais de comunicação de marketing do século XXI.

\section{Objetivos do estudo}

Tendo em vista o descrito, o objetivo principal deste estudo é analisar as métricas de resultados de investimentos em comunicação de marketing offline e online.

Os objetivos específicos são:

- propor um modelo de adoção de métricas de avaliação dos resultados das ações de comunicação offline e online apontadas pela amostra como as mais importantes. 
- identificar se as empresas comparam as métricas de avaliação de investimentos em comunicação de marketing offline e online.

\section{Método adotado}

Este estudo caracteriza-se por ser uma pesquisa exploratória dividida em duas etapas: pesquisa bibliográfica, seguida de uma pesquisa de campo, por meio de entrevista em profundidade.

De acordo com definição de Marconi e Lakatos (2010, p. 205), no que tange à coleta de dados, esta pesquisa foi constituída por duas etapas: documentação indireta e documentação direta.

A etapa inicial do estudo teve como objetivo levantar um arcabouço teórico sobre os temas do estudo: comunicação de marketing offline e online e métricas de avaliação de resultados das decisões de comunicação offline e online. O levantamento de fontes de informações secundárias foi feito a partir de livros, artigos, periódicos acadêmicos, anais de congressos acadêmicos, teses, dissertações, revistas, jornais e sites.

Tendo em vista os objetivos desta pesquisa e o estágio de conhecimento sobre o tema, este estudo adotou uma metodologia exploratória, pois segundo Godoy (1995, p. 58):

(...) a pesquisa qualitativa não procura enumerar e/ou medir os eventos estudados, nem emprega instrumental estatístico na análise de dados. Parte de questões ou focos de interesse amplos, que vão se definindo à medida que o estudo se desenvolve.

A segunda etapa da coleta consistiu de levantamento de campo para verificação de como as empresas estudadas avaliam em condições empíricas os resultados dos investimentos em comunicação offline e online. A coleta de dados foi efetuada por meio de entrevista em profundidade, com sete, das dez maiores instituições financeiras que atuam no Brasil, segundo avaliação do Banco Central do Brasil (BACEN, 2011).

O procedimento analítico adotado foi o método de análise de conteúdo: 
(...) conjunto de técnicas de análise das comunicações que utiliza procedimentos sistemáticos e objetivos de descrição de conteúdo das mensagens. (...) A intenção da análise de conteúdo é a inferência de conhecimentos relativos às condições de produtos, inferência que recorre a indicadores quantitativos ou não. (BARDIN, 2007, p. 40).

Por meio deste instrumento, chega-se a um entendimento mais profundo do texto analisado. No caso desta pesquisa, o texto estudado foi a transcrição das entrevistas realizadas com profissionais envolvidos nas decisões de comunicação de marketing das sete instituições estudadas.

\section{Estrutura da tese}

A tese está organizada em cinco capítulos. No primeiro, é apresentada a fundamentação teórica, com os resultados do levantamento bibliográfico sobre comunicação de marketing e suas respectivas ferramentas de comunicação offline e online; métricas e métricas de avaliação de resultados dos investimentos em comunicação offline e online.

O segundo capítulo aborda características e particularidades do setor de bancos, escolhido para esta pesquisa.

O terceiro capítulo apresenta a descrição e a justificativa do método adotado na pesquisa empírica e engloba a metodologia da pesquisa, o método de coleta, a amostra e os procedimentos analíticos. A pesquisa de campo foi realizada com instituições financeiras, devido ao volume e à diversidade de investimentos que estas instituições fazem em comunicação de marketing offline e online.

O quarto capítulo trata da análise da pesquisa empírica e apresenta o processo de coleta e a análise dos dados.

O quinto capítulo da pesquisa apresenta as considerações finais do estudo, as contribuições, as limitações do estudo e as recomendações para estudos futuros. 


\section{FUNDAMENTAÇÃO TEÓRICA}

Neste capítulo é apresentada a fundamentação teórica a partir do levantamento bibliográfico sobre comunicação de marketing offline e online e suas respectivas ferramentas; métricas e métricas de avaliação de resultados dos investimentos em comunicação offline e online.

\subsection{Comunicação de marketing}

O conjunto de ações que permitem às empresas comunicar suas ofertas também é conhecido, no meio acadêmico e no mercado, por "promoção" devido ao ato de promover a oferta. Segundo McCarthy (1960, p. 480), “os objetivos da promoção são informar, persuadir ou lembrar os consumidores sobre o marketing mix da empresa".

Apesar de, ao longo dos anos, o termo promoção estar sendo substituído por comunicação, encontram-se ambas as expressões na literatura sobre o tema. Neste estudo será adotado o termo comunicação de marketing para referenciar as decisões de marketing desta natureza. Apesar de ter sido encontrado na literatura o acrônimo Marcom (SCHULTZ; SCHULTZ, 2003; SCHULTZ, 2004b,) para comunicação de marketing, a autora optou por utilizar as expressões "comunicação de marketing" e "comunicação".

A comunicação envolve a coordenação de todos os esforços para estabelecer canais de informação que conduzam à persuasão dos consumidores a comprar bens e serviços de uma organização convencendo-os da capacidade de essa oferta preencher suas necessidades e desejos. A comunicação corresponde ao processo pelo qual pensamentos, conceitos ou informações são transmitidos e o significado é compartilhado entre pessoas ou entre organizações e pessoas (SHIMP; 2002, p. 31; BELCH; BELCH, 2008, p. 137).

$\mathrm{Na}$ literatura de negócios, designou-se que empresas que atendem diretamente o mercado consumidor são empresas B2C. Hutt e Speh (2010, p.4-6) definem que as empresas que atendem outras empresas, instituições de ensino, hospitais e governo são denominadas B2B. Diversas empresas atendem a ambos os mercados e lidam com 
desafio de atender às particularidades de cada mercado e de estabelecer diferentes formas de comunicação de marketing com estes dois mercados.

Mowen e Minor (2003, p. 192), Blackwell et al (2005, p. 73) e Solomon (2008, p. 325), estudiosos do comportamento do consumidor indicam que o consumidor B2C percorre um processo de decisão de compra, ilustrado na Figura 1 em que são apresentadas as dimensões que compõem o Modelo do comportamento do consumidor.

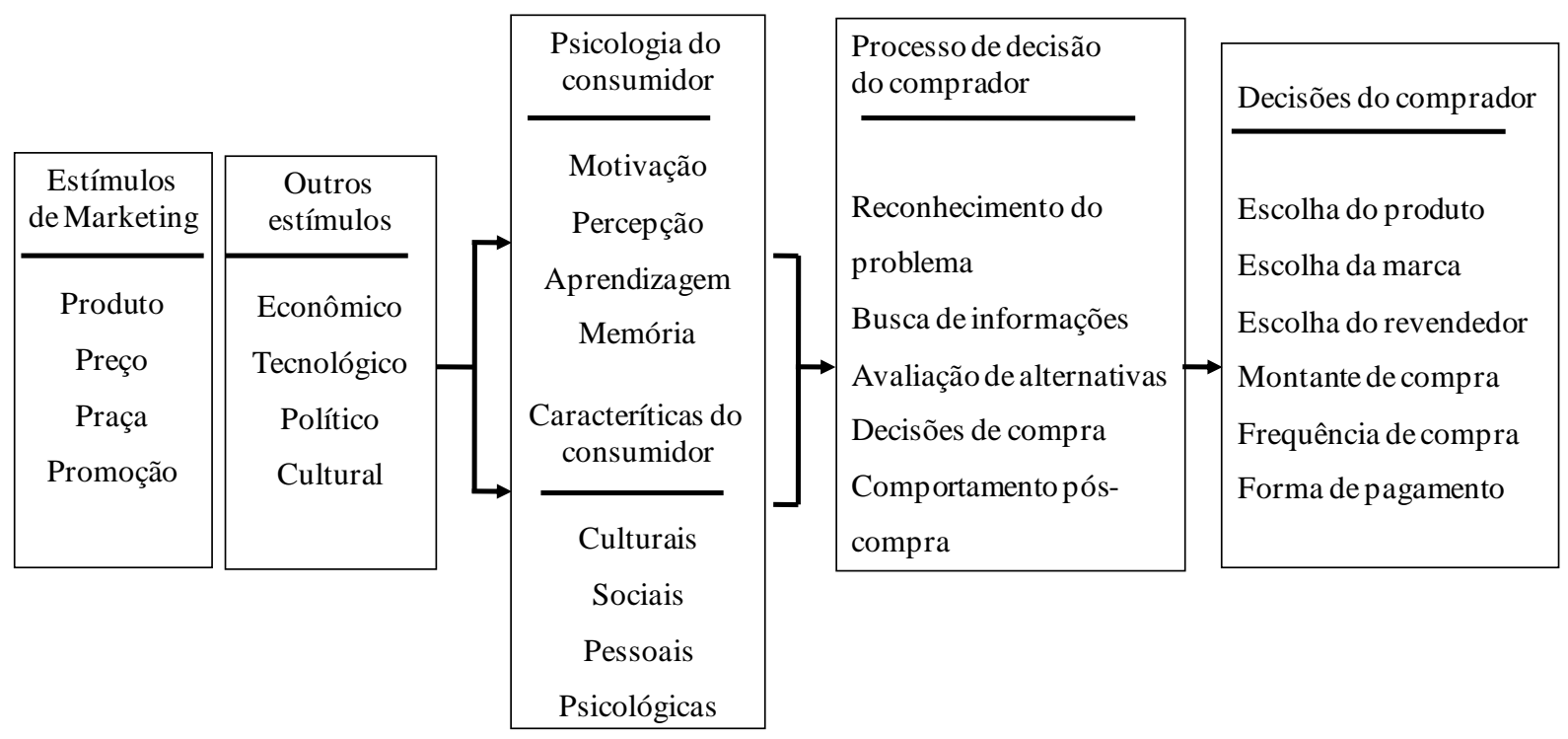

Figura 1 - Modelo do comportamento do consumidor FONTE: KOTLER; KELLER; 2006, p. 183.

De acordo com a Figura 1, ao longo do processo de decisão de compra, a comunicação de marketing pode influenciar a primeira etapa - reconhecimento do problema ao gerar interesse por uma oferta. A segunda etapa também pode ser impactada pela comunicação, na medida em que as empresas exercem controle sobre as ferramentas de comunicação de marketing. Nesta etapa do processo de decisão de compra, os consumidores recorrem à sua memória como fonte interna de informação. A memória é um dos quatro elementos que compõem a psicologia do consumidor: Motivação, Percepção, Aprendizagem e Memória do Modelo do comportamento do consumidor apresentado na Figura 1.

Blackwell et al (2005, p. 456) assinalam que a comunicação tem a capacidade de influenciar o processo de decisão de compra quando existe proximidade física com algum estímulo que permita que um ou mais sentidos sejam ativados. 
Mowen e Minor (2003, p. 166) exploram a dimensão do sentido ao definirem que

a comunicação consiste no uso de um sinal para transmitir um significado. Este sinal pode ser uma verbalização, expressão vocal, um movimento do corpo, uma palavra escrita, uma figura, um odor, um toque ou até mesmo pedras no chão para denotar um limite de propriedade.

A posição de Mowen e Minor é reforçada por Schmitt (1999), que lançou o conceito de marketing das experiências. Segundo este autor, o consumidor deseja mais do que atributos, benefícios, qualidade e imagem positiva de uma marca, ele deseja comunicações e campanhas que deslumbrem e estimulem seus sentidos, toquem seus corações e estimulem suas mentes (SCHMITT, 1999, p. 22). Este autor cita o exemplo de como a Coca-Cola adota tanto a comunicação tradicional, baseada em elementos gráficos, quanto a comunicação experiencial, quando recorre à exploração dos sentidos (SCHMITT, 1999, p. 25).

\section{Objetivos da comunicação de marketing}

De acordo com Shimp (2002, p. 112), os esforços de comunicação de marketing podem ter ao menos um destes objetivos:

i) gerar desejo pela categoria do produto;

ii) criar consciência de marca;

iii) melhorar atitudes e influenciar intenções;

iv) facilitar a compra.

Gerar desejo pela categoria do produto, também denominado demanda primária, trata de situações de lançamento de uma categoria desconhecida pelo consumidor. A comunicação de marketing é útil para introduzir o consumidor à nova oferta e despertarlhe desejo em experimentá-la.

Os dois demais objetivos - criar consciência de marca, melhorar atitudes em relação à oferta e influenciar intenções - envolvem uma situação de demanda secundária por uma marca e ocorrem após o consumidor estar familiarizado com a categoria. Estes objetivos envolvem a disputa do interesse e desejo dos consumidores pelas marcas que concorrem 
numa mesma categoria. Belch e Belch (2008, p. 19) tratam como demanda seletiva o que Shimp chama de demanda secundária.

Para Shimp (2002, p. 112) o último objetivo da comunicação, referente a facilitar a compra, é preenchido em situações em que a comunicação pode superar impedimentos criados pelas demais variáveis do composto de marketing - produto, preço e praça.

Para que os objetivos de comunicação sejam atingidos, Shimp (2002, p. 112) ressalta que é necessária a melhora contínua do valor da marca e sua gestão ao longo de seu ciclo de vida. Esta gestão começa com a definição inicial de uma identidade de marca e de um conceito. Este conceito, também chamado de significado de marca, deve apelar para uma das três categorias básicas de necessidade: funcional, simbólica e experimental, ou experiencial, que se refere a uma experiência, conforme definição de Schmitt (1999, p. 22).

Para Belch e Belch (2008, p. 31), os objetivos da comunicação são relacionados ao que a empresa procura realizar com seu plano promocional, podendo incluir:

i) criação de consciência ou conhecimento sobre um produto e seus atributos ou benefícios;

ii) criação de imagem;

iii) desenvolvimento de atitudes favoráveis, preferências ou intenções de compra.

\section{O fluxo de comunicação de marketing}

Ikeda e Crescitelli (2003, p. 7) aplicam ao modelo clássico de comunicação conceitos da comunicação de marketing, conforme exposto na Figura 2. Os autores indicam a importância da distinção da forma de comunicação, ou ferramenta de comunicação, do meio de comunicação e incorporaram ao tradicional modelo de comunicação as diferentes ferramentas ou elementos do mix de comunicação, tais como propaganda, promoção de vendas, merchandising e comunicação no ponto de venda, vendas pessoais, marketing direto, relações públicas, publicidade, marketing digital e patrocínio. 


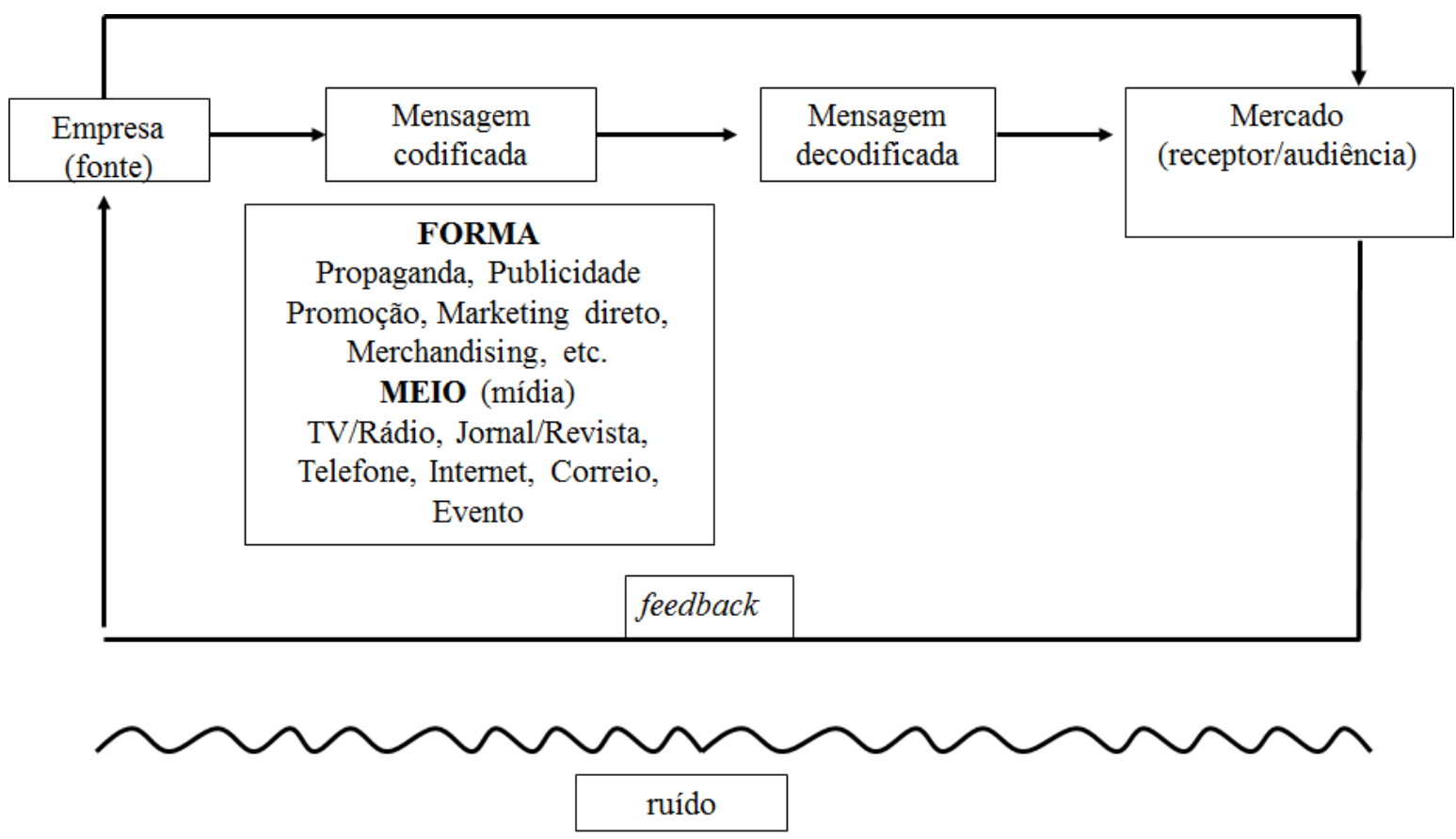

Figura 2 - Fluxo de comunicação de marketing - forma e meio FONTE: IKEDA; CRESCITELLI; 2003, p. 7.

Ikeda e Crescitelli (2003, p. 7) alertam sobre a confusão entre formas e meios. Tenta-se classificar inadequadamente, as formas de comunicação entre comunicações de massa e segmentadas. Esta classificação aplica-se, no entanto, aos meios/mídia. Os meios são as diferentes mídias ou veículos existentes para as ferramentas de comunicação, tais como televisão, rádio, jornais, revistas, eventos, internet ou correio, entregarem a mensagem da comunicação e será aprofundada no item 1.1.1.

Na Figura 2, a forma corresponde aos elementos do mix de comunicação, ou decisões de comunicação, as quais serão discutidas mais detalhadamente no item 1.1.1.

Além da mídia e da forma, outra decisão essencial à comunicação de marketing é sobre o conteúdo da mensagem. Para Sargeant e West (2001, p. 17) relevância e efeito de ser uma novidade são elementos fundamentais da mensagem. Quem desenvolve a mensagem, na maioria dos casos, são profissionais dos diversos fornecedores de serviços de comunicação de marketing: relações públicas, agências de publicidade, de promoção no ponto de venda e agências especializadas em marketing digital. Além disso, pode haver distintos agentes que participam da escolha da mensagem. Numa agência de publicidade offline, por exemplo, os profissionais envolvidos podem ser de atendimento ao cliente, planejamento, mídia e criação. 
Para garantir o entendimento dos objetivos de comunicação de marketing do cliente pelos diferentes agentes envolvidos no desenvolvimento da comunicação, algumas agências de publicidade baseiam-se num briefing escrito pelo cliente, no qual, de forma geral, são descritos a situação, características do público-alvo e os objetivos da ação de comunicação, a fim de serem propostas mídias e mensagens adequadas (SARGEANT; WEST, 2001, p. 2).

\subsubsection{Ferramentas do mix de comunicação de marketing offline e online}

Há diferentes definições na literatura para o conjunto das ações relativas à divulgação dos produtos e serviços de uma empresa: "mix promocional" (AAKER; BIEL, 1993, LAWRENCE et al, 2002, BELCH; BELCH, 2008) e "mix de comunicação" (SHIMP, 2002; IKEDA; CRESCITELLI, 2003).

As atividades que integram o mix da comunicação de marketing são: propaganda; publicidade; relações públicas; patrocínio, promoção de vendas; marketing direto; merchandising; marketing interativo, pela internet ou marketing digital; eventos; merchandising e venda pessoal (BELCH; BELCH, 2008, p. 17-23; SHIMP, 2002, p. 32). Nesta pesquisa optou-se por adotar o termo marketing digital, em substituição a marketing interativo/pela internet, utilizado por alguns autores.

Para McDonald e Moucey (2011, p. 59), despesas de marketing correspondem aos gastos destinados à função de marketing. Para Farris et al (2007, p. 91), despesas de marketing correspondem ao gasto total com atividade de marketing, que incluem propaganda e promoção não relacionadas a preço.

Nesta pesquisa serão adotadas as expressões "despesas", "gastos" ou "investimentos" em comunicação de marketing, para os gastos com finalidade de comunicar um produto, serviço ou marca.

Além das atividades de comunicação de marketing mencionadas por Belch; Belch (2008) e Shimp (2002), Ogden e Crescitelli (2007) propõem ações de comunicação adicionais. 
Conforme pode ser observado na Figura 3, estes autores classificam o conjunto das ferramentas do mix de comunicação em três grupos: i) tradicionais; ii) complementares e; iii) inovadoras. Conforme esta figura, os diferentes componentes de cada grupo são diferenciados segundo o maior nível de massificação ou de segmentação. Ou seja, a propaganda é uma alternativa adequada para objetivos de comunicação de massa, estando no extremo das ferramentas de comunicação. Por outro lado, a venda pessoal é indicada para uma situação em que se busque uma segmentação extrema, ou mais especificamente uma comunicação customizada.

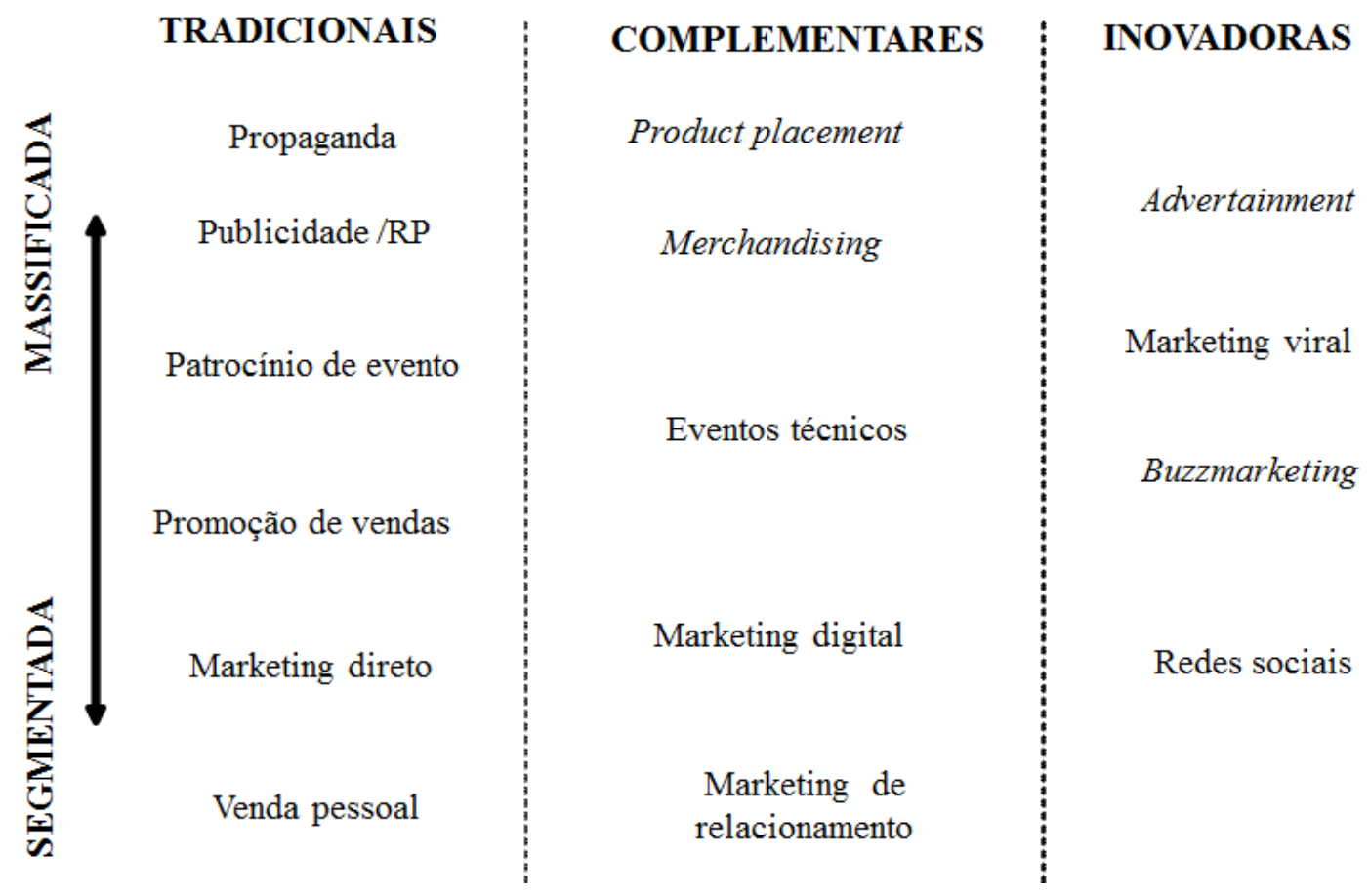

Figura 3 - Mix de comunicação de marketing

FONTE: Adaptado de OGDEN; CRESCITELLI; 2007, p. 24.

Day (2011, p. 183) destaca o aumento da importância de ações de comunicação inovadoras como mídias sociais, product placements, eventos técnicos e marketing viral frente aos veículos tradicionais. Devido à importância das redes sociais, a autora incluiu esta ferramenta entre as mídias inovadoras da Figura 3 que sumariza, segundo Ogden e Crescitelli (2007, p. 24) as ações de comunicação mais relevantes.

Kliathcko (2009, p. 11-12) ressalta que, nas últimas décadas, tem havido uma troca de mídias de massa para modelos de comunicação um a um e, mais recentemente para 
mídias de convergência. A convergência tem possibilitado que o consumidor possa engajar-se em diferentes mídias num único produto como o celular, laptops ou tablets.

Dias (2003) e Quelch e Cannon-Bonventre (1983) incluem a embalagem como elemento de do mix de comunicação, ao contrário de outros autores para quem embalagem é uma decisão relativa ao produto. Kotler e Keller (2006, p. 385) classificam a embalagem como decisão de produto, no entanto, destacam que “embalagens bem desenhadas podem criar valor de conveniência e promocional". Churchill e Peter (2003, p. 275) também incluem embalagem como produto, mas afirmam que "a embalagem pode ser usada para promover o produto". Neste estudo a embalagem não será incluída no mix de comunicação.

A seguir serão apresentadas as definições para as ferramentas do mix de comunicação considerando a classificação proposta por Ogden e Crescitelli (2007 p. 24), ou seja, segundo o agrupamento de tradicionais, complementares e inovadoras.

\section{Propaganda}

A propaganda é uma das ferramentas essenciais para a sustentação do posicionamento, que segundo Ries e Trout (2001, p. 2), corresponde à posição que este produto ocupa na mente do potencial cliente consumidor. As funções da propaganda são informar, agregar valor e persuadir (SHIMP, 2002, p. 221).

Esta ação de comunicação de marketing envolve toda forma paga de comunicação sobre uma organização, produto, serviços ou ideia. Por ser paga, uma característica da propaganda é a possibilidade de identificação de seu patrocinador.

A principal função da propaganda é criar imagem que possa transmitir o posicionamento desejado pela empresa (OGDEN; CRESCITELLI, 2007, p.24).

Para Belch e Belch (2008, p.52),

(...) a posição de produto, serviço, ou loja é a imagem que vem à memória, além dos atributos que os consumidores percebem como relacionado ao produto, serviço ou loja. A 
comunicação desta posição ocorre por meio da própria mensagem, a qual explica os benefícios e a estratégia de mídia das empresas para alcançar o público-alvo.

Para Shimp (2002, p.180),

(...) a comunicação de marketing pode facilitar o processo de comunicar as vantagens relativas de um novo produto, mostrando como ele é compatível com as preferências de compra já existentes do consumidor e com seus valores, reduzindo a complexidade real ou percebida.

Um aspecto inerente a este elemento do composto de comunicação é o benefício de envolver uma mensagem de conteúdo controlado para um grande número de pessoas ao mesmo tempo e de forma padronizada. Por outro lado, a propaganda não permite a personalização da mensagem e é uma comunicação de via única, não sendo possível uma interação com o público-alvo (OGDEN; CRESCITELLI, 2007, p. 25).

Outra característica da propaganda é sua impessoalidade, decorrente do fato de envolver mídias de massa, como televisão, rádio, revista e jornais (BELCH; BELCH; 2008; SHIMP, 2002). Por esta característica, a propaganda é a forma de comunicação mais conhecida e é reconhecida como uma das melhores formas de construção de marca. Para Shimp (2002, p. 218), "a propaganda é um investimento no banco do valor da marca".

Para Ogden e Crescitelli (2007, p. 24), a propaganda consiste,

(...) no desenvolvimento e na execução de qualquer mensagem de lembrança, informação ou persuasão comunicada a um mercado ou público-alvo, geralmente de forma não pessoal, ou seja, de maneira massificada. Sua principal característica é criar a imagem, ajudando no posicionamento do produto. Portanto seus efeitos são de médio e longo prazo.

A propaganda é inspirada em características do comportamento do consumidor, a partir deste entendimento são exploradas ideias, imagens e sentimentos relativos à análise das motivações, atitudes favoráveis ou desfavoráveis às marcas e ofertas e às características psicográficas do mercado-alvo (MOWEN; MINOR; 2003, p. 29-30).

Para Lavidge e Steiner (1961, p. 59) uma das funções da propaganda é produzir vendas. Mas este não deve ser o único objetivo, a propaganda detém o poder de influenciar o consumidor ao longo de um processo de longo prazo que permite a passagem por três estágios: conhecimento, afetivo e comportamental. 
De acordo com Belch e Belch (2008, p. 19), a propaganda nacional dirigida para o mercado de consumidores tem como objetivo informar ou lembrar sobre uma empresa ou marca, seus diferenciais e benefícios, vantagens ou usos para criar ou reforçar sua imagem de modo que os consumidores se predisponham a comprá-la.

Os anunciantes que atuam no mercado B2B podem ser prestadores de serviços como instituições financeiras, planos de saúde, transportadoras ou ainda fabricantes de matérias-primas e partes dos componentes. Estes anunciantes recorrem à propaganda para construção de imagem e geração de contatos para a força de vendas. O públicoalvo da propaganda B2B são os profissionais que compram ou influenciam o processo de decisão de compra, na etapa de "atribuição de responsabilidades" indicada na Figura 1. A propaganda para profissionais, como médicos, consultores, engenheiros ou professores, além dos objetivos de imagem e lembrança, pode estimulá-los ao uso da oferta ou para recomendar a oferta aos usuários finais (BELCH; BELCH, 2008, p. 19).

Hutt e Speh (2010, p.390) apontam que "a propaganda industrial possui restrições como o fato de não dever substituir a venda pessoal efetiva - devendo suplementar, dar apoio e complementar aquele esforço".

De acordo com a Figura 4, Ogden e Crescitelli (2007 p. 57) indicam que os objetivos da propaganda são agrupados em três categorias relacionadas às situações de:

i) introdução de uma nova categoria;

ii) institucional de reforço de produto;

iii) de manutenção, que busca provocar uma reação favorável ou oferecer um estímulo.

Belch e Belch (2008, p. 570) consideram que ações de propaganda corporativa ou institucional são uma extensão de relações públicas. Portanto, apesar da denominação propaganda, este tipo de ação será tratado no tópico relativo a relações públicas. 
SITUAÇÃO

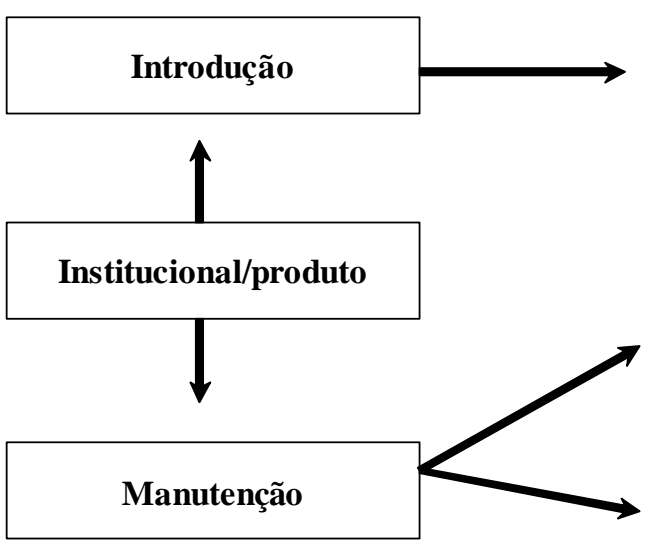

\section{OBJETIVO}

\section{Cognitivo}

Percepção (atenção e reconhecimento)

Conhecimento (informações e orientações)

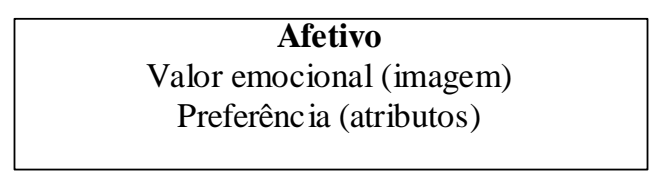

Comportamental

Reação (atitude favorável)

Estímulo (ofertas e benefícios)

\section{Figura 4 - Objetivos genéricos da propaganda}

FONTE: OGDEN; CRESCITELLI; 2007, p. 57.

Um setor com concorrentes estabelecidos, como no caso dos bancos adota propaganda com objetivos institucionais e de manutenção e também de introdução nos casos de lançamentos de novos serviços.

Historicamente e ainda nos dias atuais, empresas de diferentes ramos de negócio adotam a propaganda, que é efetiva tanto para públicos de consumidores quanto para organizações (B2C e B2B). Segundo Toledo (1978, p. 74), na décade de 70 a propaganda e relações públicas eram os veículos de comunicação de marketing mais adotados pelos bancos.

Cobra (2000, p. 198), vinte anos após Toledo (1978), salientou a importância da propaganda no composto de comunciação dos bancos, pois por meio desta ação: “(...) uma instituição torna-se mais bem aceita e respeitada pela comunidade com a qual interage direta e indiretamente (...)".

O’Cass e Grace (2004, p. 250) concordam com a importância da propaganda para o setor bancário e concluíram num estudo com clientes de bancos que a propaganda atua como fonte de informação e como formadora de imagem da marca no que tange à qualidade e ao profissionalismo, sendo uma importante ferramenta para essas finalidades. 
Para Corrêa (2007, p. 224), a propaganda dos bancos pode ter objetivos institucionais para definir e construir a imagem da corporação, junto aos diversos públicos interessados, ou de produto para destacar os diferenciais e vantagens de cada oferta. Estudo realizado pelo autor sobre 102 comerciais de TV de 17 bancos em período não especificado indicou que quase $60 \%$ das mensagens eram de cunho institucional e o restante de produto. Este resultado sugere a importância da formação da imagem da marca para o setor bancário.

\section{Relações Públicas}

Kotler e Mindak (1978, p. 17-19) foram uns dos primeiros a identificar uma relação entre relações públicas (RP) e marketing. A despeito de suas distintas origens e de as funções desempenhadas por profissionais com diferentes perfis - comunicação e marketing e jornalistas -, Kotler e Mindak (1978) sugeriram cinco possíveis arranjos entre as duas funções num espectro que começa com duas funções separadas e independentes até outro extremo em que ambas as funções são gerenciadas conjuntamente por um mesmo departamento. Os autores também propuseram classificar as empresas segundo sua orientação para marketing e o uso de RP, chegando a categorias que iam desde baixa orientação para marketing e uso de RP até intensa orientação e utilização de RP.

Tedlow (1979, p. 193), pesquisou sobre a aplicação desta ferramenta de comunicação de marketing ao longo de 50 anos e concluiu que a sobrevivência de RP, ao longo de tantos anos, deveu-se ao fato de oferecer dois benefícios fundamentais aos negócios. O primeiro é o aumento de vendas e o segundo e mais importante, é a proteção que oferece contra riscos de impopularidade que possam acarretar efeitos desfavoráveis junto ao governo e agências reguladoras.

Segundo Shimp (2002, p. 480), RP “constituem uma atividade organizacional voltada para a promoção de boa vontade entre uma empresa e seus diversos públicos", sendo orientada para os empregados, fornecedores, acionistas, governo, público em geral, sindicatos, ONGs e consumidores. Pelo fato de ter como alvo todos os públicos importantes de uma organização, nem todas as atividades de RP estão relacionadas a 
ações de marketing propriamente ditas. RP podem ser adotadas tanto por empresas B2B quanto B2C.

RP promove a empresa e seus produtos com abordagens que variam desde a perspectiva tradicional de instrumento para a manutenção de relações favoráveis com os stakeholders, até o novo paradigma de que seja uma ferramenta de comunicação de marketing. RP avalia as atitudes públicas e executa plano para desenvolver percepção favorável à empresa.

Ogden e Crescitelli (2007, p. 125) apontam como objetivos de RP:

i) o gerenciamento da reputação, da empresa;

ii) o lobby, que devido à conotação negativa da palavra, é denominado gerenciamento de interesses públicos e envolve o gerenciamento das comunicações com funcionários, públicos e entidades reguladoras;

iii) o gerenciamento de eventos especiais planejados no plano de CIM. A gestão e objetivos destes eventos serão explicados no item patrocínio de evento.

Segundo Belch e Belch (2008, p. 544), este elemento do mix de comunicação vem sendo adotado com alguns objetivos como aumento da consciência de marca, informação e educação do mercado, obtenção de entendimento, construção de confiança, oferecimento aos consumidores de uma razão para comprar e para motivar a aceitação do consumidor.

Para Kotler e Keller (2006, p.593-594), o papel do RP envolve divulgar empresas, seus produtos e construir suas imagens por meio de algumas tarefas:

i) apoio em lançamento de novos produtos ou serviços;

ii) reposicionamento de um produto ou serviço maduro;

iii) captação do interesse por uma categoria de produtos;

iv) influência sobre grupos-alvo específicos;

vi) defesa de produto;

vi) construção de imagem corporativa. 
A construção de imagem corporativa é um dos tipos de propaganda corporativa, que “(...) é uma extensão da função de relações públicas.” (BELCH; BELCH, 2008, p. 563).

Além da construção de imagem, Belch e Belch (2008, p. 565-568) apontam mais dois outros tipos de propaganda corporativa:

i) patrocínio de eventos esportivos e artísticos, turnês de entretenimento, festivais, feiras, eventos e causas, tema que será tratado do item relativo a patrocínio de evento;

ii) Advocacy Advertising, dirigida às questões sociais, de negócios ou ambientais, maneira de " (...) adotar muito mais um posicionamento sobre uma questão particular do que promover a própria organização” (BELCH; BELCH, 2008, p. 568)

Kitchen e Schultz (2003, p. 67) defendem que haja uma distinção entre esforços de relações públicas de produtos e relações públicas corporativas, sobretudo nos casos de empresas com diferentes marcas. No entanto, ressaltam os autores, esta orientação requer uma análise pontual e ajustes em situações de empresas com um único produto ou B2B.

Para Ogden e Crescitelli (2007, p. 125) as ferramentas de RP são publicações, eventos, patrocínios, notícias na mídia, palestras e aparições, atividades de prestação de serviços de interesse público e identidade de mídia.

Grunig e Grunig (1998, p. 144-145) ressaltam a importância do planejamento estratégico de RP. Os autores propõem que sejam identificados os públicos aos quais serão direcionados os esforços de comunicação e que estes esforços tenham o intuito de desenvolver relacionamentos estáveis, abertos e baseados em confiança. Smith (2010, p. 55) reforça o foco que RP deve ter no desenvolvimento de relacionamentos.

Grunig e Grunig (1998, p. 145) indicam que, para aumentar a efetividade das comunicações corporativas, estas ações devem ser integradas pelo departamento de RP para garantir a inclusão da comunicação na gestão da estratégia.

Em termos de classificação, as relações públicas aplicadas ao marketing, ou RPM podem envolver ações proativas ou reativas (SHIMP, 2002, p. 480). As RPM proativas 
são orientadas pelos objetivos de marketing e podem ser adotadas em conjunto com propaganda, promoções e venda pessoal. Shimp (2002, p. 480-481), aponta três formas de RPM proativas:

i) comunicados sobre produtos relativos à comunicação de um lançamento de produto ou ajuste de produto existente;

ii) declarações executivas, comunicados que reproduzem falas de executivos;

iii) artigos informativos, que são descrições detalhadas de produtos ou outros programas, escritos por empresas de RP para veiculação em mídia impressa, de difusão ou sites.

As RPM reativas envolvem ações de RP em resposta a influências externas resultantes de pressões ou a desafios decorrentes de iniciativas da concorrência, mudanças nas atitudes do consumidor, novas políticas governamentais ou outra influência do ambiente de marketing (SHIMP, 2002, p.480).

Sobre a gestão das ações de RP nas organizações, Grunig e Grunig (1998, p. 148) indicam que as funções de RP são desempenhadas por uma área independente da que gerencia as decisões de comunicação de marketing. Os autores sugerem que para garantir o alinhamento estratégico e evitar dicotomias, a área de comunicação de marketing reporte-se ao departamento de RP ou seja por ele coordenada.

\section{Publicidade}

Esta ferramenta de comunicação está relacionada à geração de notícias sobre uma empresa, pessoa, produto ou serviço em diferentes mídias, sendo considerada um subconjunto dos esforços de relações públicas (SMITH, 2010, p. 50; KITCHEN; PROCTOR, 1991, p. 266; KOTLER; MINDAK, 1978, p. 14).

De acordo com Shimp (2002, p. 79), a publicidade envolve a propagação de informações positivas sobre uma empresa, produto ou serviço. Como a propaganda, a publicidade também tem a função de criar imagem e é uma forma de comunicação de massa, mas dela difere por sua veiculação envolver comunicações impessoais relativas à organização, ao produto, ao serviço ou às ideias que não são pagas diretamente ou 
veiculadas por patrocinador que possa ser identificado pelo leitor ou telespectador. Além de a publicidade criar imagem, Smith (2010, p. 50) salienta sua capacidade de persuadir o consumidor.

Para Loda et al (2005, p. 363), Cameron (1994, p. 186), Hallahan (1999, p. 294) e Shimp (2003, p. 79), a publicidade tem mais credibilidade que a propaganda, recebe o endosso do veículo no qual é veiculada, podendo beneficiar-se da imagem e reputação deste veículo, sobretudo em se tratando de uma publicidade positiva à empresa ou oferta. Hunt e Grunig (1993, apud LODA et al, 2005, p. 363) apresentam uma posição contrária ao afirmar que há poucas evidências científicas de que as pessoas, quando leem uma matéria num jornal, realmente acreditem que os jornalistas endossem um produto.

Hallahan (1999, p. 295) salienta que a publicidade apresenta a desvantagem de não ser controlada, pois ao contrário da propaganda, não há controle sobre o conteúdo publicado, nem a possibilidade de repetição da informação no mesmo veículo.

A publicidade também é adotada como uma forma de as empresas reagirem à publicidade negativa, quando uma empresa ou sua oferta é envolvida numa situação desfavorável à sua imagem. Esta situação pode ser um acidente ambiental, associação a envenenamentos e usos de matérias-primas que possam trazer algum risco à saúde ou segurança de seus usuários.

Para Shimp (2002, p. 480), a publicidade é a principal ferramenta das RPMs proativas, tendo como objetivo principal aumentar o valor de uma marca de duas formas:

i) facilitando a consciência da marca;

ii) melhorando a imagem da marca por meio de associações fortes e favoráveis feitas pelos consumidores.

\section{Patrocínio de evento}

Convém ressaltar que o patrocínio de um evento é diferente do patrocínio de um programa de TV como Big Brother, que é classificado como propaganda (BELCH; 
BELCH, 2008, p. 349), ou ainda do patrocínio de conteúdo na internet, em que o patrocinador paga pela associação de uma palavra a seu nome e pela aprovação do conteúdo (BELCH; BELCH, 2008, p. 476).

Kotler e Keller (2006, p. 594) e Shimp (2002, p. 485) classificam esta ferramenta de comunicação como uma ação de RP. O patrocínio “(...) é uma forma de promoção de marca em que esta é associada a um evento atlético, de lazer, cultural social ou outro tipo de atividade de interesse público.” (SHIMP, 2002, p. 485).

Para Ogden e Crescitelli (2007, p. 26), “patrocínio é a prática de promover os interesses de uma empresa e suas marcas a um evento específico ou uma causa".

A origem de ações de patrocínio esteve associada com a filantropia. Aos poucos os patrocínios foram sendo ampliados para outras áreas, mas há uma forte concentração em esportes, artes e eventos sociais.

Neste tipo de ação, o mercado participa do evento, o que permite a oportunidade de interação social entre os participantes e a geração de uma experiência. Quanto mais engajado o público for com o tema do evento patrocinado, tanto melhor será sua opinião sobre o patrocinador (CLOSE et al, 2006, p. 420).

Para funcionar, o evento patrocinado deve atender a alguns requisitos. O primeiro é que o público corresponda ao mercado-alvo desejado. O evento também deve gerar uma atenção que justifique o investimento e reflita a imagem da marca patrocinadora.

Apesar de patrocínio não ser propaganda, esta ação de comunicação de marketing preenche os três estágios propostos por Lavidge e Steiner (1961, p. 61) atendidos pela propaganda: conhecimento, afetivo e comportamental.

Esta ação visa criar uma imagem como a propaganda e a publicidade, porém por meio da associação com uma imagem já existente. O patrocínio vem se mostrando uma alternativa num momento em que a mídia de massa para divulgação de ofertas e marcas vem perdendo espaço para mídias mais segmentadas. 
Aaker e Joachimsthaler (2000, p. 217) indicam que patrocínios são um meio para a construção de marcas, devido aos fatores descritos na Figura 5.

O primeiro fator ilustrado nesta figura refere-se ao fato de que, além do público-alvo, os funcionários são afetados pelo orgulho de pertencer a uma organização que apoia determinada iniciativa.

Sobre "fornecer uma experiência", segundo fator, relativo à construção de imagem, os patrocínios permitem um contato direto com os clientes. Esta posição é defendida por Schmitt (1999, p. 26) para quem patrocínio é uma forma de as empresas proporcionarem experiências a seus clientes e experiências costumam envolver "aspectos sensoriais, emocionais, cognitivos, comportamentais e valores relacionais que substituem valores funcionais“.

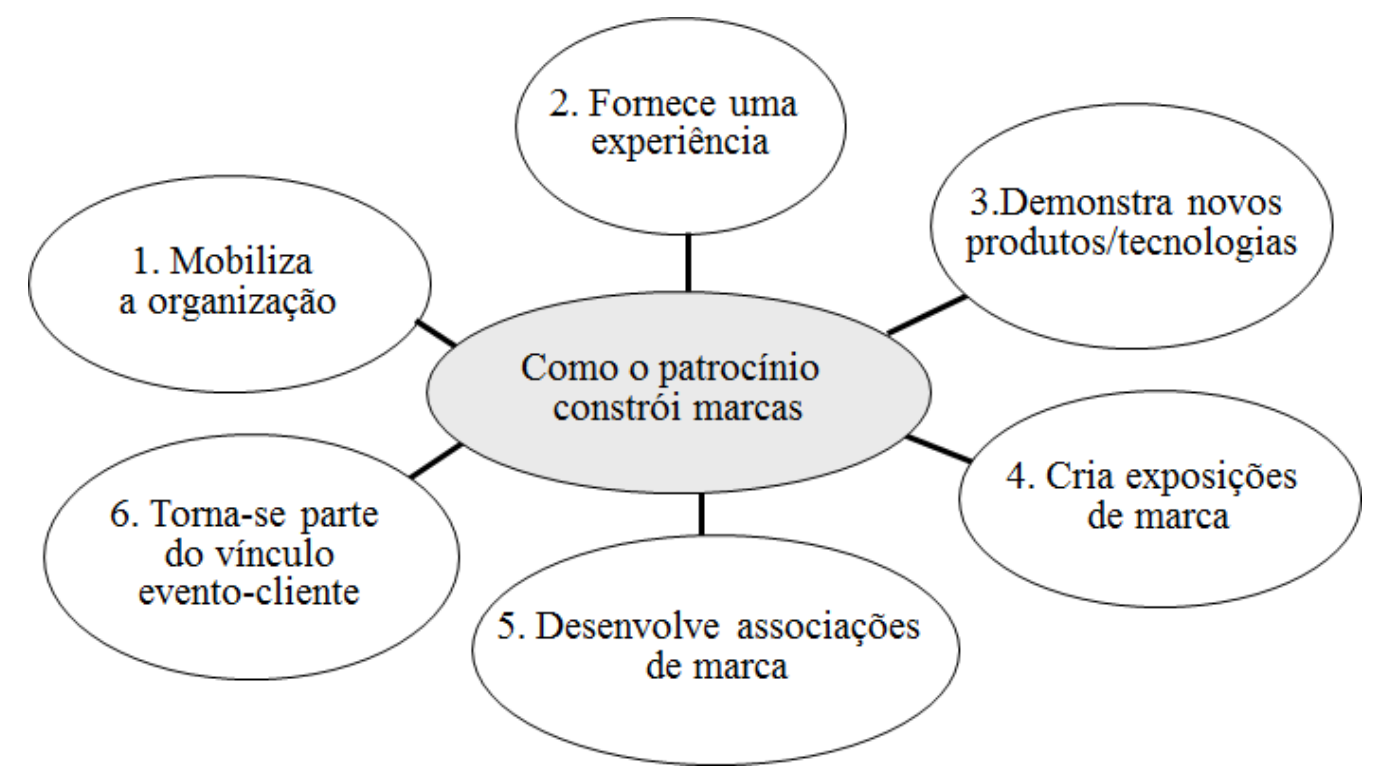

Figura 5 - O patrocínio como construtor de marca

FONTE: Adaptado de AAKER; JOACHIMSTHALER; 2000, p. 217.

Para Aaker e Joachimsthaler (2000, p. 219), o terceiro fator decorre de que "(...) um patrocínio pode ser a alavanca necessária para elevar o valor de notícia de um produto ou tecnologia de forma que o resultado seja a cobertura por parte da imprensa (...)”.

O patrocínio também pode criar exposições de marca - quarto fator de criação de marca - em decorrência da cobertura que a mídia dará ao evento. 
Sobre o quinto fator - Desenvolve associações de marca - , Aaker e Joachimsthaler (2000, p. 222-224) apontam que os patrocínios podem desempenhar papel crítico nas associações de características funcionais do produto, sustentação de posição de liderança e reconhecimento de posição global.

No que tange à possibilidade de tornar-se parte do vínculo evento-cliente,

(...) o evento patrocinado pode ser uma parte significativa de suas vidas e um veículo para expressar suas identidades - para alguns fazer parte da audiência de uma ópera (...) é importante para seu autoconceito. (AAKER; JOACHIMSTHALER, 2000, p. 230).

Jensen e Hsu (2011, p. 361) desenvolveram estudo sobre os resultados atingidos por ações de patrocínio feitas pelas 50 empresas norte-americanas que mais investiram nesta ferramenta de comunicação de marketing no período 2005-2009. Neste estudo foi identificada uma relação entre patrocínio e valor de marca, uma vez que houve uma presença significativa das empresas estudadas no ranking anual global da pesquisa da Interbrand. Este ranking levanta as marcas mais valiosas, segundo o que Kotler e Keller (2006, p. 284) denominaram avaliação do valor da marca.

Kotler e Keller (2006, p. 284) explicam que a relação ocorre devido ao fato de as ações de patrocínio serem recomendadas para marcas estabelecidas que, normalmente, possuem maior nível de conhecimento e são menos dependentes de mídias tradicionais para tornar suas marcas conhecidas, podendo investir um percentual maior de seu orçamento em ações táticas como patrocínio. Novas marcas, por outro lado, não podem arriscar deixar de dedicar uma proporção significativa de seu orçamento a mídias de massa tradicionais para estabelecer suas marcas. Esta posição é reforçada por Deane $e t$ al (2003, p. 197), que recomendam que ações de patrocínio sejam adotadas por empresas que já tenham suas marcas conhecidas e objetivem reforçar a personalidade destas marcas.

Para Belch e Belch (2008, p. 523), neste tipo de comunicação uma empresa ou marca é ligada a um evento cuja atividade temática é desenvolvida com o propósito de criar experiências para os consumidores, bem como promover um produto ou serviço. Os mesmos autores indicam que no patrocínio, uma empresa oferece apoio financeiro para a realização de um evento em troca do direito de exibir sua marca, logotipo ou 
mensagem publicitária. Muitas vezes as decisões de patrocínio fazem parte das atividades de RP, por este motivo, alguns autores o tratam como subconjunto de decisões de RP. (BELCH; BELCH 2008, p. 524). Para Drengner et al (2008, p. 144) a avaliação da imagem de um evento influenciará a imagem da marca da empresa organizadora.

Ogden e Crescitelli (2007, p. 26) apontam o risco de que uma empresa seja prejudicada pela imagem de um patrocinado, por exemplo, um atleta. Para evitar transtornos, os autores recomendam a celebração de um contrato e o monitoramento das atividades do patrocinado.

Cobra (2000, p.198) salienta a importância do patrocínio no composto de marketing de instituições financeiras: “(...) uma instituição torna-se mais bem aceita e respeitada pela comunidade (...), sobretudo quando ela patrocina alguma instituição filantrópica de interesse da comunidade".

Em 2009, os gastos globais com esta ferramenta de comunicação somaram US\$44 bilhões, sendo aproximadamente $40 \%$ concentrados nos Estados Unidos (JENSEN; HSU, 2011, p. 353).

No Brasil, os gastos em patrocínio para atividades esportivas e culturais também são significativos. Na última categoria, a Lei Rouanet e a Lei de Audiovisual, promulgadas respectivamente em 1991 e 1993, impulsionaram os patrocínios culturais no Brasil ao fornecer incentivos fiscais a atividades culturais como shows, eventos culturais, centros culturais, a produção e distribuição de filmes.

O setor bancário é bastante ativo em patrocínios esportivos e culturais. De acordo com a Tabela 1, relativa ao período 2006-2008 e formulada a partir de dados do Ministério da cultura, a maioria dos bancos considerados nesta pesquisa utiliza os incentivos das Leis Rouanet e de audiovisual.

Somados todos os incentivos de todas as instituições relacionadas, Itaú, Bradesco e Banco do Brasil, figuram entre os cinco maiores incentivadores das Leis Rouanet e de audiovisual no Brasil no período 2006-2008. 
Dentre as atividades culturais patrocinadas pelos bancos considerados nesta pesquisa, o Banco do Brasil dispõe dos centros culturais, Centros Culturais Banco do Brasil (CCBB) em São Paulo, Rio de Janeiro, Distrito Federal e Belo Horizonte. O Itaú possui o Instituto Itáu Cultural em São Paulo. A Caixa Econômica Federal (CEF) tem Espaços Caixa Cultural em oito localidades: Brasília, Curitiba, Fortaleza, Porto Alegre, Recife, Rio de Janeiro, Salvador e São Paulo. O Santander disponibiliza o Santander Cultural em Porto Alegre e Recife. Estes espaços culturais oferecem ao longo do ano diferentes manifestações culturais, tais como exposições, palestras e peças de teatro. Alguns contam com bibliotecas para consulta.

Tabela 1 - Bancos Patrocinadores Culturais Valores relativos às Leis Rouanet e Audiovisual 2006-2008 (em mil R\$)

\begin{tabular}{|c|c|c|c|c|}
\hline Banco & $\mathbf{2 0 0 6}$ & $\mathbf{2 0 0 7}$ & $\mathbf{2 0 0 8}$ & Total \\
\hline ABN AMRO Real & 5270 & 8165 & 2784 & 16219 \\
\hline Banco do Brasil & 25093 & 21536 & 24833 & 71462 \\
\hline Bradesco & 23453 & 33341 & 38811 & 95605 \\
\hline Caixa Econômica Federal & 2111 & 1897 & 3021 & 7029 \\
\hline Citicard & 2240 & 0 & 0 & 2240 \\
\hline HSBC & 2468 & 4122 & 7791 & 14381 \\
\hline Itaú & 20953 & 31700 & 21185 & 73838 \\
\hline Unibanco & 1528 & 1878 & 1610 & 5016 \\
\hline Total & 83116 & 102639 & 100035 & 285790 \\
\hline
\end{tabular}

Bradesco - Somatório Banco Bradesco, Bradesco Capitalização, Bradesco Saúde, Bradesco Capitalização, Banco Bradesco BBI e Bradesco Consórcios e Bradesco Leasing

Itaú - Somatório dos apoios de: Instituto Itaú Cultural, Itaú Previdência e Seguros S/A, Banco Itaú Cartões S/A, CIA. Itaú

Unibanco - Somatório Unicap Unibanco, Unibanco AIG Seguros, Unibanco AIG e Previdência, Unibanco Companhia de Capitalização e Unibanco Holding S/A

2008 - Ano da fusão Itaú - Unibanco

FONTE: MINISTÉRIO DA CULTURA; [2011]; BANCO CULTURAL; [2011]

Há também salas de cinema e teatros patrocinados, como Teatro Bradesco em São Paulo e Cinemas Itaú/Unibanco em Curitiba, Fortaleza, Porto Alegre, Rio de Janeiro, Salvador, Santos e São Paulo, que dão visibilidade frequente aos patrocinadores e associação a atividades culturais. 
Além de atividades culturais, os bancos patrocinam esportes. A CEF, banco não entrevistado nesta pesquisa, mas que faz parte da população estudada, foi patrocinadora oficial dos Jogos Pan-americanos Rio 2007 e das seleções de Atletismo e de Ginástica Artística, Rítmica e Trampolim. Além disso, as loterias administradas pela CEF patrocinaram nos últimos anos o Comitê Paraolímpico Brasileiro (CPB) e a Delegação Paraolímpica Brasileira nos Jogos Paraolímpicos de Pequim 2008.

Em 2011, a CEF é a patrocinadora oficial dos atletas da Confederação Brasileira de Atletismo, dos ginastas da Confederação Brasileira de Ginástica, dos lutadores da Confederação Brasileira de Lutas Associadas e dos atletas paraolímpicos brasileiros.

Desde 1991, o Banco do Brasil (BB) patrocina atividades esportivas. Segundo o site da instituição, em 2006 e 2007, foram investidos em marketing esportivo, respectivamente $\mathrm{R}$ \$ 45,6 milhões e R\$ 60 milhões. O destaque dos últimos anos têm sido as seleções brasileiras de vôlei masculina e feminina, que garantiram importantes títulos ao longo de 20 anos em competições exclusivas desta modalidade esportiva e nas Olimpíadas e Jogos Pan-americanos. Além do vôlei de quadra, o BB patrocina e investe no vôlei de praia e no futsal. Outra iniciativa de patrocínio é o iatista Robert Scheidt, octacampeão mundial e bicampeão olímpico, que acumulou ao longo de 16 anos de patrocínio 154 títulos. Segundo o site do BB, “(...) o Banco do Brasil acredita que Scheidt agrega valor à imagem da empresa." (BANCO DO BRASIL, 2011). O BB também investe desde 2000 no patrocínio ao tênis por meio do projeto TênisBrasil.

\section{Promoção de vendas}

Este elemento do mix de comunicação trata de atividades que correspondem a um estímulo direto que oferece um valor extra ou incentivo para a força de vendas do produto ou serviço, para os intermediários de marketing (como distribuidores atacadistas e varejistas) e para o consumidor final com o principal objetivo de venda imediata (SHIMP, 2002, p. 32; BELCH; BELCH, 2008, p. 22; OGDEN; CRESCITELLI, 2007, p. 78). 
A promoção de vendas vem ampliando sua participação no plano de comunicação integrada. A partir da segunda metade da década de 1980, a proporção do orçamento destinado à promoção de vendas subiu em detrimento dos investimentos em propagada.

Estudo mencionado por Schultz e Schultz (2003, p. 7) apontava que, na virada do século, a participação da promoção de vendas no orçamento de comunicação era de $52 \%$ contra $48 \%$ na década de 1980 . Outra pesquisa referida por BELCH; BELCH (2008, p. 497), indicava que, em 2005, 60 a 75\% da verba de comunicação era destinada a gastos com promoção de vendas.

A relevância da promoção de vendas é reforçada por outra pesquisa da Point-OfPurchase Advertising International (POPAI), associação comercial dedicada ao marketing de varejo. De acordo com esta pesquisa, $85 \%$ das compras são decididas no ponto de venda (BLESSA, 2005, p. 1).

Segundo Ogden e Crescitelli (2007, p. 77), a promoção de vendas é uma atividade complementar aos outros elementos do mix de comunicação e deve apoiar os objetivos gerais do plano de CIM e do Plano de Marketing.

Além da venda imediata no curto prazo, a promoção de vendas pode ter outros objetivos como a experimentação de lançamentos, atingir novos segmentos de mercado, regularizar excesso de estoques, neutralizar ações da concorrência e divulgar e reforçar o valor de uma marca (OGDEN; CRESCITELLI, 2007, p. 77).

De acordo com Belch e Belch (2008, p. 497-501), o incremento nos gastos com promoção de vendas é motivado por situações ou objetivos específicos para o fabricante, o intermediário varejista e o consumidor final. Segundo estes autores as razões que justificam o aumento dos gastos em promoção de vendas pelo fabricante são:

i) saturação de mídias tradicionais;

ii) maior orientação para resultados de vendas de curto prazo;

iii) maior facilidade de avaliação do desempenho das ações de promoção, do que outras ferramentas do mix de comunicação como a propaganda;

iv) forma mais fácil de reagir e criar barreiras às ações da concorrência; 
v) fragmentação do mercado consumidor, que faz com que os fabricantes busquem abordagens mais segmentadas e direcionadas.

Para Belch e Belch (2008, p. 497-501), a justificativa para a adoção de promoção de vendas pela ótica do intermediário varejista é o aumento de seu poder de compra em relação aos fabricantes. Pela ótica do consumidor, os motivos que explicam o incremento em promoção de vendas são relacionados:

i) ao aumento da sensibilidade do consumidor às promoções no ponto de venda;

ii) à intensificação da concorrência com a consequente proliferação de marcas nas diversas categorias;

iii) ao declínio da lealdade do consumidor à marca.

A promoção de vendas ocorre tanto no mundo real, quanto no virtual. No mundo real, o varejo é um intermediário representativo para a aplicação de promoções de vendas.

Segundo Blackwell et al (2005, p. 136), no processo de decisão de compra, entender onde comprar os produtos está relacionado às decisões de qual tipo de loja - física, internet, catálogo ou mala direta, o tipo de loja - hipermercado, supermercado, loja de departamento, etc. - para, subsequentemente, ser definido qual o varejo. Para os profissionais de marketing, entender esta decisão implica a adoção de uma estratégia de distribuição e de promoções de vendas apropriadas.

A seguir serão apresentados os tipos mais comuns de promoção de vendas, segundo Belch e Belch (2008, p. 496 e p. 501-533).

i) O uso de amostras ou sampling gera a mais alta taxa de experimentação dentre as alternativas de ações de promoção de venda. Seu uso é indicado para produtos com valor unitário baixo, divisíveis e com ciclo de compra curto. Podem ser feitas amostragens por porta a porta, correio, no ponto de venda (PDV), na embalagem, revistas, jornais ou num evento.

ii) Cupons são amplamente adotados nos Estados Unidos e sem relevância no mercado brasileiros, os tipos mais comuns de cupons são de recompra, vale-troca, instantâneo e 
na loja, quando há uma embalagem cooperada com o varejo. Apesar da influência que a cultura e os hábitos da sociedade norte-americana exercem no Brasil, esta modalidade de promoção de vendas não é bem-sucedida no país.

iii) Os brindes podem ser gratuitos ou a preços baixos também denominados de autoliquidação. Nestes últimos, em que é cobrado um valor ao consumidor, o objetivo não é ganhar dinheiro, mas cobrir os custos destes brindes. Ogden e Crescitelli (2007, p. 85), denominam este tipo de brinde de compra subsidiada e ressaltam a importância de que os brindes sejam realmente desejáveis pelo consumidor a fim de aumentar o retorno da promoção.

iv) Concursos são uma promoção em que os consumidores concorrem a prêmios ou dinheiro com base no julgamento de suas capacidades ou habilidades.

v) Sorteios tratam de situações em que os agraciados são determinados ao acaso e são mais comuns que concursos. Belch e Belch (2008, p. 520) apontam como restrições ao uso de concursos e sorteios:

a) o fato de agregarem pouco valor à marca, podendo até prejudicá-la;

b) a existência de questões legais complicadoras;

c) a possibilidade de atrair pessoas que consideram um hobby participar destas promoções, ao invés de consumidores ou potenciais consumidores.

vi) Reembolsos, também conhecidos como descontos e mais adotados para produtos, consistem numa promoção de vendas em que o fabricante devolve uma parte do preço de compra ao consumidor. Esta ação tem como objetivo gerar a experimentação e a repetição de compra, quando a comprovação de compra implica o envio de comprovante de compra, podendo tanto manter quanto conquistar novos usuários. Como ponto fraco, os reembolsos requerem esforço do usuário para usufruir do benefício (BELCH; BELCH, 2008, p. 521).

vii) Embalagem bônus oferece ao consumidor uma quantidade extra de um produto ao preço regular da embalagem padrão. É capaz de gerar recompra, mas não atrai novos 
usuários, pode retardar recompra e impedir a volta do consumidor ao PDV. É indicada para bens de consumo (BELCH; BELCH, 2008, p. 522).

viii) Descontos diretos ao consumidor são oferecidos diretamente na embalagem. Este tipo de promoção permite maior controle pelo fabricante e pode influenciar o volume comprado pelo usuário, mas corre o risco de não ser aceito pelo varejista por impactar em sua margem de lucro. Seu impacto é maior para recompra. (BELCH; BELCH, 2008, p. 522).

ix) Belch e Belch (2008, p. 522-523) apontam que programas de fidelidade, também conhecidos como programas de frequência ou continuidade, são populares para a fidelização do cliente, tendo como objetivo pelo fabricante a recompra pelo fabricante.

Nesta pesquisa não será feita distinção entre as expressões "fidelidade de cliente" e "lealdade do cliente", que serão adotadas com o mesmo sentido.

Amplamente adotado por empresas de serviços de viagem e hospedagem, também têm se popularizado entre varejistas, como supermercados e livrarias. Para o consumidor, o principal benefício é a obtenção de descontos decorrentes de acúmulo de pontos.

Instituições financeiras aplicam programas de fidelidade ao fornecerem descontos progressivos nas taxas de manutenção das contas decorrentes da contratação de serviços como cartões de crédito, débito automático de contas de consumo, títulos de capitalização, aplicações financeiras, dentre outros.

Ogden e Crescitelli (2007, p. 86-87) apontam outras promoções de vendas. Member get member, atividade em que um cliente recebe uma recompensa pela indicação de outro cliente e a demonstração, promoção que envolve a experimentação de um produto, como degustações em supermercados ou test drive de veículos. Os autores apontam que a diferença básica da demonstração para a amostragem é que nesta última não há garantia de que o consumidor experimente o produto, uma vez que a promoção é controlada por um promotor. 
Outro tipo de promoção de vendas apontado por Ogden e Crescitelli (2007, p. 87) é o comprador misterioso, também denominado comprador oculto ou fantasma. Esta modalidade é destinada aos intermediários e envolve a presença de uma pessoa que se faz passar por um cliente. Este indivíduo avalia o comportamento do vendedor. Caso seu desempenho seja bem avaliado ele pode ganhar um prêmio. Outra modalidade de promoção de vendas são os eventos que serão tratados no tópico de eventos técnicos.

Belch e Belch (2008, p. 501-533) propõem que as diversas ações de promoção de vendas sejam planejadas tendo em vista as diferentes etapas do ciclo de vida do produto - introdução, crescimento, maturidade e declínio. O Gráfico 1 ilustra a proposição destes autores quanto à adoção das diferentes formas de promoção de vendas ao longo do ciclo de vida.

Tendo em vista a natureza do produto oferecido pelos bancos - serviços - , nem todas as modalidades de ações de promoção de vendas apresentadas neste tópico se aplicam ao setor. As que se aplicam são: promoções de incentivos para os gerentes de conta, concurso, sorteio, brindes e programa de fidelidade. Estes últimos são exemplificados pelos descontos concedidos aos correntistas para manutenção de contas especiais. A medida que são contratados mais serviços, como investimento, colocação de contas em débito automático, seguros de vida e automóvel, financiamento, cartão de crédito, previdência privada ou empréstimos, o correntista tem uma redução na taxa cobrada.

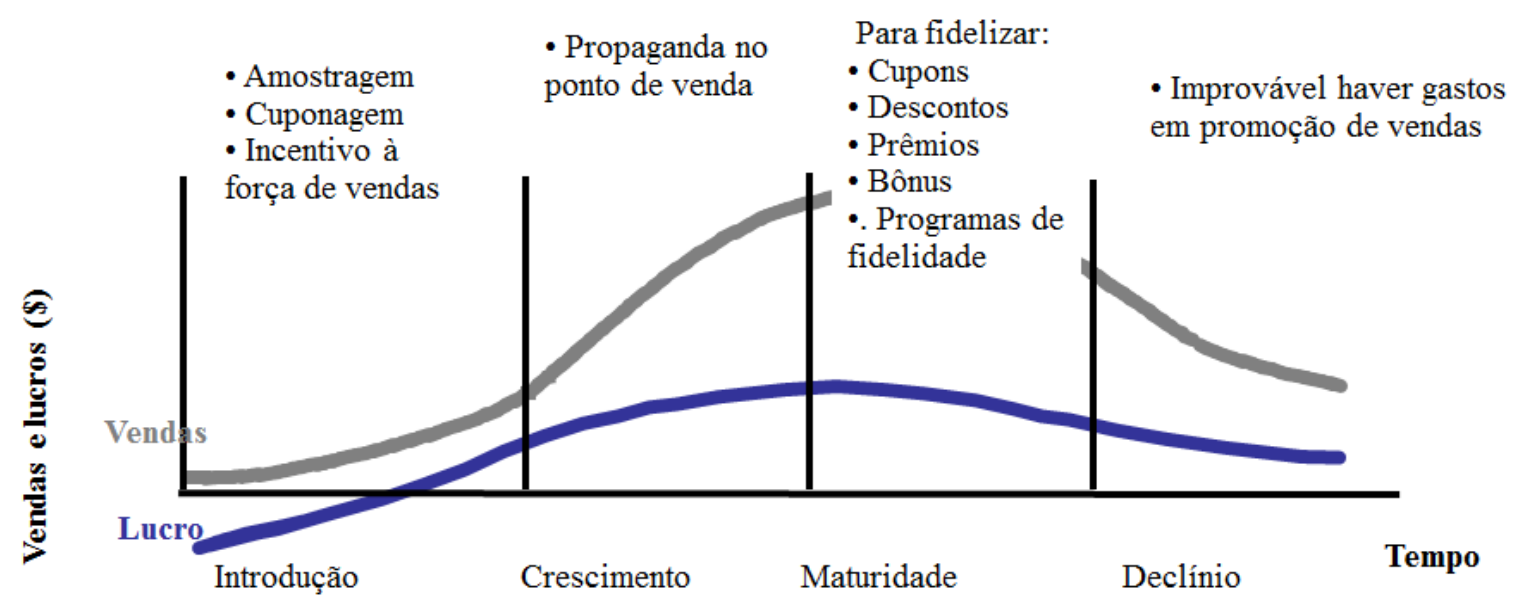

Gráfico 1 - Ferramentas de promoção de vendas ao longo do ciclo de vida do produto

FONTE: Adaptado de BELCH; BELCH; 2008, p. 501-533. 
Em relação ao Gráfico 1, nem todas as ações de comunicação indicadas por Belch e Belch (2008, p. 501-533) aplicam-se ao setor bancário, tais como cupons e descontos. Os bancos no Brasil encontram-se no estágio de maturidade do ciclo de vida de seus serviços. No entanto, cada novo serviço introduzido experimenta a etapa de introdução do ciclo de vida apresentada nesta figura.

\section{Marketing direto}

Segundo Belch e Belch (2008, p. 18), marketing direto refere-se à comunicação direta com o cliente-alvo para gerar resposta e/ou provocar uma transação por meio de mala direta, catálogos, database, venda direta, telemarketing, internet, dentre outras mídias. Envolve contato personalizado e interativo.

Tendo em vista a relevância e as particularidades do marketing direto por meio da internet, este tipo de comunicação será retomado no item relativo ao marketing digital.

De acordo com definição da Direct Marketing Association (SHIMP, 2002, p. 325), marketing direto "é um sistema interativo de marketing que usa uma ou mais mídias de propaganda para gerar uma resposta mensurável e/ou uma transação em qualquer local”. $\mathrm{O}$ aspecto interativo deve-se ao fato de envolver uma comunicação personalizada com o potencial cliente ou cliente. O marketing direto pode ocorrer por correio, telefone, quiosque, internet ou até por visitas pessoais com o uso da mala direta, incluindo catálogo, telemarketing e venda direta.

Em conjunto com vendas pessoais, o marketing direto forma o grupo de comunicações pessoais, distintos dos demais elementos de comunicação, que são considerados ações de massa (KOTLER; KELLER, 2006, p. 606-618).

O marketing direto é considerado uma ferramenta de comunicação que usa uma ou mais mídias de propaganda para gerar uma resposta mensurável e/ou uma transação em qualquer local (SHIMP, 2002, p. 325).

Segundo Belch e Belch (2008, p. 447), o marketing direto existe desde a invenção da imprensa, conforme apontam alguns usuários desta ação de promoção, como Ben 
Franklin e Warren Sears. Seus grandes impulsionadores foram, no entanto, o aprimoramento do serviço postal e, posteriormente, o avanço tecnológico que viabilizou o desenvolvimento dos bancos de dados com o registro e a manutenção dos dados de clientes e clientes em portencial (BELCH; BELCH, 2008, p. 450). O banco de dados é peça fundamental para a adoção do marketing direto e deve ser atualizado continuamente.

Na década de 1970, Lester Wunderman cunhou a expressão marketing direto, definindo-a como propaganda mensurável (ROSENWALD, 2005, p. 2). À medida que o marketing direto foi se consolidando, algumas empresas substituíram as custosas vendas pessoais, por telemarketing e pela venda pelo correio, por meio da mala direta. Outras empresas adotaram o marketing direto para complementar a função da equipe de vendas (SHIMP, 2002, p. 327; ROSENWALD, 2005, p. 2).

Apesar da forte relação entre o marketing direto e vendas, este não é o único objetivo deste elemento de comunicação, “(...) algumas organizações o utilizam para construir uma imagem, manter a satisfação do cliente e informar e/ou instruir os clientes na tentativa de levá-los a ações futuras”. (BELCH; BELCH, 2008, p. 449-450).

Shimp (2002, p. 328) aponta como características favoráveis à adoção da mala-direta:

i) mensurabilidade, inerente ao marketing direto.

ii) precisão, por permitir atingir um segmento específico.

iii) responsabilidade, ao permitir aos gestores que utilizam a mala-direta justificar seus orçamentos;

iv) flexibilidade para alteração do conteúdo para diferentes segmentos ou para os mesmos em momentos distintos;

v) eficiência de poder focar esforços de comunicação para um segmento selecionado.

Além destes pontos fortes do marketing direto, Belch e Belch (2008, p. 463-464) indicam a possibilidade de esta ferramenta permitir o alcance de diferentes níveis de frequência, a rapidez com que podem ser desenvolvidas as ações desta natureza e os baixos custos envolvidos. Por outro lado, os autores apontam algumas desvantagens, como a imagem negativa gerada pelo excesso de marketing direto que justificou a 
expressão junk mail e o risco da baixa precisão, caso a listagem adotada seja inadequada ou ultrapassada.

Pesquisa nos Estados Unidos sobre preferência de mídia para ações de marketing direto indicou que em 2010, a despeito da consolidação da internet como meio de comunicação, $73 \%$ dos consumidores norte-americanos preferiam receber informações sobre novos produtos ou empresas com as quais têm relacionamento por meio do correio, em seguida por e-mail (18\%), por meio de telefone $(1 \%)$ e outros ou sem resposta (8\%) (MILLER; WASHINGTON, 2011, p. 352).

Schulaka (2010, p. 8) cita pesquisa realizada em 2010, com 300 empresas sobre a efetividade de geração de pedidos de propostas a qual constatou que o resultado é maior quando são adotadas e-newsletters. Ou seja, clientes B2B e B2C preferem, respectivamente, a internet e o correio como mídia para adoção de marketing direto.

Dados da Abemd (Associação Brasileira de Marketing Direto) indicam que o marketing direto vem crescendo nos últimos anos. Em 2009 o mercado de marketing direto movimentou R\$ 19,3 bilhões. Ao longo do período 2000-2007, houve um crescimento médio anual de $11 \%$. Este resultado superou a expansão registrada no mercado publicitário no mesmo período no Brasil, que foi de $9 \%$. Vale destacar que o levantamento dessa associação considera tanto marketing direto offline quando online.

Segundo dados da Abemd, dentre os serviços relacionados a esta modalidade de comunicação, a internet e e-commerce, incluídas no levantamento de gastos com marketing direto, movimentaram $25 \%$ do faturamento. Neste ano, no que tange ao público-alvo das ações de marketing direto, a maioria (66\%) foi destinada ao mercado B2C.

O setor bancário oferece um serviço de massa para uma grande quantidade e variedade de clientes, com diferentes perfis socioeconômicos e demandas específicas. A combinação destas características à necessidade de precisão e controle internos e externos das operações efetuadas tornaram necessários contínuos investimentos tecnológicos para criação e atualização frequente dos bancos de dados de operações. 
Estes fatores devem explicar o fato de que, segundo Belch e Belch (2008, p. 455), as instituições financeiras foram um dos primeiros setores a adotarem o marketing direto.

No Brasil, dados de pesquisa anual da Abemd, relativos a 2009 indicam que, a exemplo de anos anteriores, as instituições financeiras foram as que mais utilizaram o marketing direto. Cerca de um quarto do que é movimentado com marketing direto foi proveniente deste setor. A utilização é explicada pelo fato de o setor bancário ser um dos que mais adotam relacionamento online com seus clientes. Em seguida vêm os setores de telecomunicações $(15 \%)$ e publicações/assinaturas $(11 \%)$. As instituições financeiras adotam o marketing por meio de telemarketing, e-mail marketing e mala direta.

\section{Venda pessoal}

É a forma de comunicação mais persuasiva, porém sua abrangência é limitada. Referese ao contato imediato entre comprador e vendedor face a face ou por meio de canal de telecomunicação, como telefone e internet podendo envolver um pequeno número de consumidores ou somente um consumidor, mas não um grande número, como no caso da propaganda (OGDEN; CRESCITELLI, 2007, p. 115).

A venda pessoal representa um importante papel para as instituições B2B e para o marketing de relacionamento. A definição de um plano promocional que considere a venda pessoal envolve a identificação de qual papel assumirá em relação aos outros elementos do mix promocional. Apesar de vantajosa em situações que envolvam clientes industriais, não se recomenda o uso da venda pessoal isoladamente, sem estar combinada a outras ferramentas.

Segundo Hutt e Speh (2010, p. 390), a venda pessoal não deve ser adotada para atingir os objetivos de conscientização ou disseminação de informações, que cabem à ação de propaganda.

Belch e Belch (2008, p. 575); Ogden e Crescitelli (2007, p. 115) e Shimp (2002, p. 496) apontam algumas vantagens da venda pessoal, como a possibilidade de o emissor receber, avaliar imediatamente o feedback de sua mensagem emitida e adequar sua mensagem ao longo do processo de comunicação, conforme os interesses e as 
características dos clientes, ou seja de forma customizada. Outro ponto forte é a possibilidade de a comunicação ocorrer simultaneamente à exibição da oferta, aumentando as chances da venda. Uma terceira vantagem é o fato de a venda pessoal beneficiar-se da atenção dada pelo cliente ao vendedor. Outra vantagem, decorrente da atenção, é a possibilidade de a venda direta permitir a transmissão de uma quantidade de informações técnicas e complexas, inviável em outras formas de promoção. Por último, a venda pessoal permite um relacionamento de longo prazo entre vendedor e cliente, o que facilita as vendas no médio e longo prazo.

Em relação a desvantagens, Belch e Belch (2008, p. 576); Ogden e Crescitelli (2007, p. 115) e Shimp (2002, p. 496) destacam o alto custo por contato da venda pessoal, em comparação à propaganda que atinge um número maior de pessoas. Hutt e Speh (2010, p. 390) salientam que apesar da importância da venda pessoal no mercado B2B, esta ação é inadequada para criar conscientização ou disseminar informações.

Wotruba (1991, p. 4) indica haver cinco estágios na evolução do papel desempenhado pela venda pessoal. O primeiro corresponde ao do vendedor provedor, ou tirador de pedido. No segundo estágio, o vendedor começa a ter um papel de persuasão e passa a tentar convencer os membros do mercado a adquirirem as ofertas disponíveis. No estágio seguinte, o vendedor tenta identificar os compradores, suas necessidades e recursos disponíveis para aquisição das ofertas de produtos ou serviços. No próximo estágio, o vendedor assume uma posição de solucionador de problema e tenta identificar de que forma as ofertas que vende podem atender seus clientes e potenciais clientes. No último estágio, o vendedor atua como um criador da solução por meio de um processo de colaboração entre o vendedor e o cliente que culminará numa solução customizada.

Nos últimos anos, surgiu nas empresas a função Key Account Manager (KAM) ou gerente de contas especiais que para McDonald et al (1997, p. 737), são vendedores adotados por empresas para atender e coordenar a interação rotineira com clientes-chave B2B. Os KAM permitem o desenvolvimento de pacotes de soluções customizadas e trazem ganhos em termos de oportunidades contínuas tanto para as empresas que os adotam quanto para seus clientes. Estes profissionais enquadram-se no último estágio proposto por Wotruba (1991, p. 4). 
Anderson (1996, p. 22-23) destaca o impacto da tecnologia no desempenho das funções de venda pessoal, sobretudo na automação da força de vendas, a venda por meio de escritórios virtuais e os canais de venda eletrônicos. Para o autor, automação da força de vendas corresponde ao uso de cada vez mais tecnologia - celular, laptop, e-mail e softwares de gestão de informação de clientes, dentre outros. O uso de escritórios virtuais está se propagando devido aos benefícios de evitar longos deslocamentos e à economia que traz às empresas que os adotam. Os canais de venda eletrônicos são sustentados pela internet, que será tratada no tópico de marketing digital.

No setor bancário, além do marketing direto, vigora a venda pessoal pelo gerente da agência, numa intensidade maior ou menor, conforme a relevância e potencial de seus clientes. Em função da complexidade do processo de decisão de compra de um cliente B2B, a venda pessoal poderá ser exercida por profissionais que atuem num dos cinco estágios descritos anteriormente.

Dando continuidade à abordagem das ferramentas de comunicação conforme a classificação apresentada na Figura 3, proposta por Ogden e Crescitelli (2007 p. 24), concluiu-se a explanação das ferramentas de comunicação tradicionais e serão introduzidos os elementos do mix de comunicação complementares.

\section{Product placement}

Primeira das ferramentas de comunicação classificadas como complementares, segundo Ogden e Crescitelli (2007, p. 28), é entendido como a inserção de produtos em programas de TV ou filmes e no Brasil, é denominado merchadising.

Nesta pesquisa, quando for feita referência a ações no ponto de venda, será adotado o termo merchandising e a expressão product placement para situações de inserção de produtos e marcas em programas, jogos, blogs, músicas, vídeos, DVDs, revistas, livros, filmes na televisão, celulares, filmes veiculados no varejo e internet (WILLIAMS et al, 2011, p. 2).

A origem do product placement é antiga, data do final do século XIX, quando os estúdios pediam produtos emprestados para baratear as produções de filmes 
(WILLIAMS et al, 2011, p. 3). O consumo do cigarro também foi alavancado pelo product placement do produto nos filmes de Hollywood em que estrelas compunham personagens fumantes (BALASUBRAMANIAN, 1994, p. 33). Nos anos 1930, a Procter \& Gamble veiculava nas rádios suas pequenas novelas nas quais estavam inseridos seus sabonetes - soaps -, daí a denominação de soap opera para novelas nos EUA (THE ECONOMIST, 2005).

Apesar de tratar-se de ação antiga, o estudo de seus efeitos foi iniciado na década de 1990. Balasubramanian (1994, p. 30) foi um dos primeiros a dar atenção a ela, enquadrando-a no que denominou de "mensagem híbrida", uma combinação de propaganda com publicidade.

Esta ferramenta de comunicação é uma forma de co-branding e vem atraindo mais empresas anunciantes à medida que filmes como Missão Impossível, Matrix, 007, ET, dentre outros, tornam-se, cada vez influenciadores do comportamento e do consumo (SCHMITT, 1999, p. 86-87; WILLIAMS et al, 2011, p. 9).

Tsai et al (2007, p. 6) atribuem alguns benefícios ao uso de product placement, tais como maior consciência e conhecimento do produto ou marca expostos, desenvolvimento de atitude positiva e intenção de compra do produto ou da marca

Balasubramanian (1994, p. 38-39) apontou algumas desvantagens de mensagens híbridas, como product placement, tais como não gerar um impacto direto e imediato como outras ações de comunicação, ser de difícil mensuração e não ser possível avaliar sua capacidade de persuasão.

De acordo com Russell e Stern (2006, p. 7), esta ação de comunicação movimentou mais US\$ 3,6 bi nos EUA, dos quais mais da metade é investido na TV. O Product Placement tem se tornado estratégico para mais de mil marcas nos EUA, incluindo algumas das 100 maiores conforme ranking da revista Fortune, que inclui empresas como Procter \& Gamble, Pepsico e Anheurser-Busch. Os autores indicam que o interesse por essa ação de comunicação vem aumentando também entre os acadêmicos havendo uma concentração de estudos em três áreas de conhecimento: memória, atitude e comportamento. 
Van Reijmersdal (2009, p. 151) relata que na maioria dos casos de brand placement, quando o foco é a marca, há efeitos favoráveis desta ferramenta de comunicação sobre a memória. No entanto, em algumas circunstâncias pode haver efeitos negativos sobre a atitude do consumidor frente à marca quando, por exemplo, há um excesso de exposição de marcas num filme, programa ou jogo cuja audiência tem pouco envolvimento com o que assiste.

Em termos de cuidados, Cowley e Barron (2008, p. 96-97) alertam que a retenção do product placement será influenciada pelo interesse do público em relação ao programa a que assistiu. É necessário não haver um excesso de exposição para não criar uma atitude desfavorável à marca, bem como que se busque inserir o produto ou serviços em programas que provoquem interesse num público com as características do serviço ou produto objeto da ação.

Russell (2002, p. 314) ressalta que o product placement dentro do enredo da situação pode ser uma fonte significativa de influência sobre a atenção e atitude da audiência, caso não seja possível, melhor inserir o produto num segundo plano.

Segundo Ogden e Crescitelli (2007, p. 28) esta forma de comunicação pode ser classificada em três níveis, conforme a intensidade da mensagem. No primeiro nível, de inserção, o produto é mostrado dentro de um contexto. No segundo, a inserção do produto é acompanhada de uma demonstração de seu uso. No terceiro nível, além da inserção e demonstração, é incluído um testemunho favorável. Este último nível é o mais próximo de uma propaganda. Para Williams et al (2011, p. 8) o product placement é mais bem sucedido nos casos em que o produto é inserido de forma planejada e espontânea, fazendo parte do script original.

Pode haver uma grande oscilação no preço cobrado pelo product placement, mas nem toda inserção é paga, pois em alguns casos os estúdios ou canais de TV recorrem a produtos e marcas consagradas para compor personagens e situações (WILLIAMS et al, 2011, p. 3).

Thomasch (2007) aponta que os EUA lideram o mercado de product placement mundial, seguido do Brasil, Austrália, França e Japão. No Brasil, em cujos lares as 
telenovelas têm penetração significativa, o product placement em novelas foi adotado em diferentes momentos como na década de 1990 para disseminar o uso de caixas eletrônicos e, no século XXI, para educar o consumidor quanto à forma de utilização da internet, recorrendo ao terceiro nível de product placement. A Rede Globo transmite novelas desde os anos 1970, algumas delas vistas por 80 milhões de pessoas. (ADVERTISING AGE, 2010).

\section{Merchandising}

As ações de merchandising referem-se às ações de comunicação no ponto de venda. Neste item da pesquisa serão apresentadas conjuntamente as ações cooperadas com o trade e as ações de comunicação no ponto de venda, também denominadas no Brasil de merchandising.

Segundo o POPAI Brasil, merchandising é "qualquer técnica, ação ou material promocional usado no ponto de venda, que proporcione informação e melhor visibilidade a produtos, marcas ou serviços, com o propósito de motivar e influenciar as decisões de compra dos consumidores" (POPAI, 2011).

O merchandising envolve o conjunto de atividades de marketing e comunicação destinadas a identificar, controlar, ambientar e promover marcas, produtos e serviços nos pontos de venda. O merchandising permite apresentar de forma destacada os produtos na loja, criando espaço e visibilidade, de maneira tal que acelere sua rotatividade (POPAI, 2011).

As ações de comunicação no ponto de venda visam dar maior visibilidade ao produto ou marca no ponto de venda. A intenção não é formar a imagem, mas reforçá-la.

Para Ogden e Crescitelli, (2007, p. 29), as ações cooperadas com o trade envolvem campanhas de comunicação de varejo desenvolvidas em conjunto pelo fabricante e pelo varejista e assinadas por ambos com a participação explícita de um deles na ação.

Devido à intensificação da concorrência, à diversificação das marcas e ao aumento do poder de barganha do varejo e a fim de aprimorar os serviços de comunicação no ponto 
de venda e a promoção de vendas, as empresas fabricantes de bens de consumo duráveis têm investido na criação da área de trade marketing.

Originado da área de vendas, o trade marketing permitiu a adequação da estratégia, da estrutura e da operação do fabricante às particularidades do varejo com a finalidade de garantir a disponibilidade dos produtos para o consumidor e a interação dos departamentos de marketing e vendas.

Motta et al (2008, p. 49) indicam que antes das transformações que vêm ocorrendo no cenário do varejo, o departamento de marketing era responsável pelo composto de marketing, enquanto o de vendas respondia pela negociação com os varejistas, com a finalidade de garantir a disponibilidade dos produtos para os consumidores finais.

De acordo com Alvarez (2008, p. 73), o trade marketing pode ser entendido como:

\footnotetext{
o planejamento e controle das ações de venda e de mercado e dos benefícios oferecidos ao consumidor final (marketing), por meio da verificação das relações de vendas estabelecidas com os varejistas (trade).
}

Segundo Mathes (2004, p. 1), apesar de bancos estarem criando marcas sólidas, alguns ainda falham em realizar vendas num importante ponto de contato com o cliente: as agências. O autor ressalta a necessidade de que haja uma integração entre os esforços de comunicação externos e os realizados nas agências, que com o tempo vêm se tornando importante canal para a venda de serviços. O mesmo autor aponta que a comunicação nas agências tenha como público-alvo não somente o cliente, mas também os funcionários, que devem estar aptos a responder sobre as demais ações de comunicação externas à agência.

Apesar da intensificação do uso da internet e do telefone para realização de operações financeiras, o número de agências continua a crescer, reforçando a adequação de esforços de comunicação nas agências bancárias. Além das agências, outro importante canal entre os bancos e seus clientes são os caixas eletrônicos, ou postos eletrônicos de autoatendimento também denominados ATM (automated teller machine). Assim como as agências, esses canais são importantes para a realização de transações, bem como divulgação de ofertas e contratação de serviços. 
As instituições financeiras são prestadores de serviços e buscam criar a identidade de sua marca também no ponto de venda e para tanto investem em diversas peças decorativas que apoiam suas campanhas de massa nas agências e reforçam sua identidade. Algumas peças adotadas nas agências bancárias são luminosos, back lights, front light, luminosos, móbiles, pôsters, cartaz aéreo, cartazetes, blimps, totem e take ones para folhetos. (OGDEN; CRESCITELLI, 2007, p. 158-160).

Ogden e Crescitelli (2007, p. 31) apontam que folhetos e catálogos são modalidades de comunicação relevantes para alguns setores como o bancário, cuja contratação dos serviços requer planejamento e é feita posteriormente à visita ao ponto de venda.

\section{Marketing digital}

A internet ocupa um espaço importante na vida do consumidor atual, tem sido responsável por significativas mudanças em seu comportamento e sua ascensão vem desempenhando um impacto radical sobre as funções de marketing. Nos últimos anos é possível constatar que a internet vem assumindo papéis que extrapolam a comunicação e exercendo a função de entretenimento, fonte de busca de informação, educação e canal de venda. Algumas empresas da internet vêm se tornando referência na vida do consumidor contemporâneo, como Google, que inspirou em países de língua inglesa o verbo "to Google"; outros sites de relacionamento bem-sucedidos são o Facebook, YouTube, LinkedIn e Twitter.

Na carona das inovações, a internet vem possibilitando também o surgimento de novas ações de comunicação, como o buzz marketing, o marketing viral e o advertainment e novas maneiras de consumo como o recente fenômeno dos sites de relacionamento. Por outro lado, como em qualquer setor com dinamismo de inovações, alguns produtos têm vida curta, como o Second Life, que no seu auge foi adotado por diversas corporações como Bradesco, HP e IBM.

Além do consumidor, as grandes corporações vêm aderindo às novidades da internet como redes sociais e Twitter. As redes sociais permitem a criação de uma nova forma de consumidores e organizações se relacionarem e compartilharem informação, bem como de gerar boca a boca, ou marketing viral. 
Colliander e Dahlén (2011, p. 318) realizaram estudo comparativo entre os efeitos da publicidade em versões online de consagradas revistas e blogs de destaque. Os resultados indicaram que a publicidade dos blogs online é mais efetiva que a gerada em publicações online. A isenção da fonte geradora do marketing viral nas redes sociais tem mais impacto do que as revistas tradicionais. As empresas deveriam identificar os blogueiros, responsáveis pela atualização de blogs, capazes de gerar um marketing viral de alto impacto e desenvolver um relacionamento genuíno com estas pessoas que dedicam tempo e empenho em promover as marcas em que acreditam.

Segundo Belch e Belch (2008, p. 469), o marketing digital envolve fluxo de mão dupla permitindo ao usuário participar e modificar a forma e conteúdo da informação de marketing e dar feedback imediato. Outra característica apontada pelos autores é a possibilidade de um contato personalizado com os usuários. Além disso, a internet distingue-se das demais alternativas adotadas num plano de comunicação, por cumprir a função híbrida de mídia de comunicação e também de canal de venda, viabilizando a comercialização eletrônica de mercadorias de diferentes naturezas e atuando como um catálogo online tanto para empresas B2B quanto B2C.

Em termos de custos de compras offline e online, Hutt e Speh (2010, p. 45) apontam que a compra pela internet é mais barata. Os pedidos online têm um custo estimado de US $\$ 5,00$ contra um valor de US $\$ 100,00$ de pedidos offline.

Para Baker (2005, p. 409-410), o marketing digital é o marketing direto aplicado à mídia internet, mas diferencia-se pela possibilidade de funcionamento 24 horas por dia ao longo dos sete dias da semana, pela interação, pela maior personalização, pela quantidade e integração de dados e pela capacidade de viabilizar a manutenção de contato a custo bem inferior ao do marketing direto por telefone ou correspondência.

Stern e Stalk Jr (2002, p. 161-164) ressaltam que a internet oferece uma combinação positiva do que denominam riqueza e alcance de transferência de informações. Para os autores, riqueza está relacionada a três aspectos. O primeiro aspecto refere-se à quantidade de informação capaz de ser distribuída nesta mídia. O segundo fator é pertinente à extensão com que a informação pode ser personalizada e o terceiro aspecto repousa na sua interatividade entre o transmissor e o receptor. A internet preenche 
favoravelmente estas três dimensões. Em relação ao alcance, entendido como o número de pessoas em diferentes ambientes - casa ou trabalho - que trocam informações, a internet também oferece um alcance positivo.

Anderson (1996, p. 25) destacou a importância da internet para a venda pessoal, pois atua como uma fonte de informações para identificação de potenciais clientes e também como canal de venda para clientes de pequeno porte que não justificariam a alocação de um vendedor dedicado. Além destas funções, a internet pode ser adotada como canal para suporte ao cliente e de apoio à venda.

Fan et al (2007/2008, p. 155) definem mídia digital como conteúdos de áudio e vídeo em formatos digitais distribuídos pela mídia internet. Segundo esses autores, as empresas continuarão adotando esta mídia devido aos avanços tecnológicos que trazem aumento da velocidade de transmissão e melhoria na definição dos monitores, conferindo avanço na experiência de visualização do conteúdo. Além disso, o baixo custo de transmissão por esta mídia desperta o interesse dos anunciantes, pois o valor cobrado para transmissão na mídia digital é irrisório frente aos custos de produção de filmes e áudios para veiculação em mídias offline. Por último, à medida que a internet passa a ampliar sua importância na sociedade, as empresas de mídia e network não podem restringir-se aos meios tradicionais de veiculação.

Outro aspecto apontado por Fan et al (2007/2008, p. 157) que alavancará a adoção da mídia digital é o DVR, equipamento que permite ao telespectador ver somente o conteúdo de seus programas na hora de sua conveniência, pulando os comerciais de TV.

Em relação ao DVR, estudos apontaram que este equipamento geraria um impacto desfavorável sobre a propaganda na TV. Pesquisa da Jupiter Media (GREENE, 2007 apud BRONNENBERG et al, 2010) indicou que, numa amostra de detentores de DVR, 47\% pulam os comerciais. Outro estudo feito pela Advertising Research Foundation identificou que $76 \%$ dos anunciantes acreditavam que DVRs impactariam o mercado da propaganda (MADDOX, 2006b).

Em reação ao impacto do DVR, as empresas de mídia e entretenimento estão investindo na veiculação de programas na internet. A ABC lançou um site onde o público com 
conexões de banda larga pode assistir gratuitamente a episódios de "Desperate Housewives", "Lost" e outros programas. É possível pausar, rebobinar e avançar. Os usuários, no entanto, não podem pular os comerciais dos programas (FAN et al 2008, p. 144).

Estudo da Advertising Age (2010) sobre hábitos de consumo de mídia indica que cada vez mais a internet substitui a TV. Em 2009, um terço do que foi veiculado na internet eram vídeos. Em 2010, este percentual passou para 40\%. Projeções da Cisco apontam que em 2014, o porcentual atinja 90\%. Segundo o mesmo estudo, Brasil, Rússia, Índia, China e Indonésia têm os consumidores mais ávidos por vídeos online. Na China e Indonésia, os internautas são $26 \%$ mais propensos a assistir a vídeos nesta mídia do que a média global de internautas. Os indianos são $21 \%$ mais inclinados e os internautas do Brasil e Rússia são $11 \%$ mais propensos a utilizar esta mídia.

Bronnenberg et al (2010, p. 1009) refutaram a posição da maioria dos estudos de que o DVR prejudica a capacidade de persuasão da TV sobre o consumidor. Num estudo com uma amostra longitudinal, desenvolvido durante 13 meses, em que foi comparado o comportamento antes e após a aquisição de um DVR, constatou-se não haver evidências de que portadores de DVR pulem comerciais de forma significativa.

Belch e Belch (2008, p. 470) indicam que as empresas vêm recorrendo à internet para que esta cumpra os seguintes objetivos:

i) ser ferramenta de divulgação e criação de uma marca;

ii) sustentar o posicionamento de uma marca;

iii) atuar como canal para comunicação com clientes e stakeholders;

iv) estimular a experimentação;

v) ser canal de venda pessoal;

vi) funcionar como meio de relacionamento com clientes;

vii) viabilizar o marketing direto.

Segundo a International Telecommunication Union (ITU, 2011), dados de 2010 relativos a 72 países desenvolvidos e em desenvolvimento, indicam que $30 \%$ de sua população tinha acesso à rede. Apesar de baixo, quando comparado à década anterior, 
este valor representa um avanço significativo, pois em 2000, a penetração da internet era inferior $1 \%$ e, em 2010, somente seis países tinham taxa de penetração menor que 1\%. (CHADE, 2011).

Comparando a penetração dos países em desenvolvimento com os desenvolvidos, temse que, em média, somente $21 \%$ da população do primeiro grupo tem acesso à rede, contra uma maioria da população nos países desenvolvidos. A posição do Brasil é acima da média mundial, mas bem abaixo da penetração europeia. Aqui $37 \%$ da população tem acesso à internet (CHADE, 2011).

No Brasil, apesar de as mídias tradicionais como $\mathrm{TV}$, revista e rádio manterem participação significativa no orçamento dos anunciantes, de acordo com a Tabela 2, a internet triplicou, ampliando sua participação nos últimos anos, tendo passado de $2 \%$ para 6\% no período 2006-2010.

Tabela 2 - Participação das mídias (\%) no faturamento do mercado da comunicação (período 2006-2010)

\begin{tabular}{|l|c|c|c|c|c|}
\hline \multicolumn{1}{|c|}{ Mídia } & $\mathbf{2 0 0 6}$ & $\mathbf{2 0 0 7}$ & $\mathbf{2 0 0 8}$ & $\mathbf{2 0 0 9}$ & $\mathbf{2 0 1 0}$ \\
\hline Cinema & 0,3 & 0,5 & 0,4 & 0,4 & 0,4 \\
\hline Guias e Listas & 2,6 & 1,2 & 1,1 & 0,9 & 1,1 \\
\hline Internet & 2 & 3,4 & 4,4 & 5 & 6 \\
\hline Jornal & 12,8 & 16,5 & 13,9 & 12,3 & 11,3 \\
\hline Mídia exterior & 3,1 & 2,5 & 2,9 & 2,8 & 3 \\
\hline Rádio & 3,9 & 4,3 & 4,4 & 4,2 & 4 \\
\hline Revista & 8,1 & 9,4 & 8,4 & 8 & 8,8 \\
\hline Televisão & 63,5 & 58,3 & 60,5 & 62,4 & 61,3 \\
\hline TV por assinatura & 3,6 & 3,7 & 4 & 3,9 & 4,1 \\
\hline Total & 100 & 100 & 100 & 100 & 100 \\
\hline
\end{tabular}

FONTE: Adaptado de pesquisa do INTER MEIOS; 2011.

A televisão permanece por larga margem como a mídia mais significativa ao longo do período 2006-2010. Sua participação está em torno de 60\% do total investido em propaganda, enquanto a de jornal permaneceu como a segunda mais significativa, seguida de revista. A quarta posição tem sido de rádio, acompanhada de perto e superada a partir de 2008 pela internet, que vem avançando sua participação 
consistentemente, passando de $2 \%$ para $6 \%$ do total de gastos em propaganda ao longo do período analisado. Apesar da importância e de diversos benefícios a ela associados, a internet ainda não representa uma ameaça para as mídias tradicionais - TV, jornal e revista - exceto rádio, à qual se igualou, em 2008 e desde então a vem superando.

\section{Desafios inerentes à mídia digital}

Apesar do potencial da internet, alguns autores assinalam desafios a serem enfrentados pelos profissionais de comunicação de marketing. Day (2011, p. 183) indica haver uma lacuna entre a capacidade das organizações, sobretudo a área de marketing, e o aumento exponencial de informações sobre o consumidor na internet. Segundo projeções do IDC (apud DAY, 2011, p. 184), o volume de dados teria passado de 100 bilhões de gigabytes em 2005, para 1000 bilhões em 2010.

Com o advento de mídias de comunicação na internet, diversas instituições passaram a usar esta mídia para comunicação e relacionamento com seus clientes conectando-se às redes sociais, criando blogs, recorrendo a blogueiros para falarem de suas ofertas ou marcas e oferecendo podcasts.

Stewart e Pavlou (2002, p. 376) destacam que até a ascensão da internet, as métricas tradicionais de efetividade de comunicação focavam no alcance dos resultados dos objetivos que impulsionaram a decisão de comunicação. Com esta nova mídia, os profissionais de comunciação de marketing passaram a lidar com um novo paradigma. A comunicação de marketing não é mais somente persuasiva e baseada no modelo de mão única: anunciante - público-alvo. Na era da internet, a comunicação tem dois sentidos e envolve a interação da empresa com os diversos públicos que passaram a criar conteúdo.

Ogden e Crescitelli (2007, p. 33) ressaltam que, apesar de ser uma mídia promissora, a internet representa uma ameaça às empresas devido à falta de controle do conteúdo das mensagens entre a empresa, seus clientes e a sociedade, em todos os sentidos e com conteúdos diversos. As manifestações desfavoráveis dos consumidores nas redes sociais e a velocidade e capacidade de cobertura destas informações na internet são um exemplo do que foi apontado por estes autores. 
A consolidação da internet tem tornado o mercado cada vez mais centrado no cliente que utiliza esta mídia não só para expor e propagar ideias, mas também para disseminar insatisfações, gerando rapidamente epidemias, como nos casos de marketing viral. Um caso real da força da internet foi protagonizado pelo achocolatado Nescau em 2008, quando foi lançada nova embalagem em substituição a uma que estava no mercado havia mais de 20 anos. Após diversas manifestações online, a Nestlé, detentora do produto decidiu atender às manifestações de consumidores e manter a versão tradicional do Nescau (MISMETTI, 2008). Outro exemplo foi a tentativa fracassada de troca do logo da marca de vestuário Gap. Tendo em vista as reações desfavoráveis dos consumidores nas redes sociais, em quatro dias de vida do novo logo, a empresa voltou atrás e retomou a versão anterior (HAMPP, 2010).

Segundo Day (2011, p. 184) vem surgindo uma nova indústria para acompanhar e entender as manifestações dos consumidores sobre os produtos e serviços das empresas e de seus concorrentes nas redes sociais. Das características e mudanças provocadas pela internet no comportamento do consumidor, emerge a questão de como a área de marketing, e sobretudo a de comunicação, lida com estes aspectos.

\section{Convergência}

Outro ponto do marketing digital que impõe desafios aos profissionais é a convergência de mídias. Segundo Costella (2001, p. 166), a convergência é uma evolução tecnológica que reduz as fronteiras dos meios de comunicação tradicionais e permite sua conversão para a rede.

A indústria de celulares tem papel decisivo para a expansão do acesso e uso da internet. Dados da Agência Nacional de Telecomunicações (Anatel) de junho de 2010 indicam que havia 217,3 milhões de acessos móveis no País, ou seja, mais celulares que habitantes no Brasil. Em 2002, a penetração de celulares era de $20 \%$ da população. (CHADE, 2011). A mobilidade será cada vez maior seja para celulares, notebooks ou tablets. O crescimento da venda de smartphones com planos de dados crescentemente acessíveis oferecidos pelas operadoras popularizará ainda mais a internet móvel. (FALKE INFORMATION, 2011). 
Dados da UIT indicam que 97 países, dentre os quais o Brasil, apresentam uma penetração de celulares superior ao número de habitantes. Em 2010, quatro bilhões de pessoas de países em desenvolvimento possuíam um celular e a taxa de penetração do produto nestes países chegou a 70\%, mesma taxa atingida em 2004 pelos países desenvolvidos (CHADE, 2011). Estudo da Advertising Age (2010) aponta que 81 milhões de indianos (7\% da população) usavam a internet em 2010, contra 507 milhões detentores de celulares. O mesmo cenário repete-se na China (20\% contra 57\%) e Indonésia (5\% ante $66 \%)$.

A inserção da mídia celular tem impactado a forma como as empresas se comunicam e relacionam com seus públicos-alvo e, a partir dela, foram criados dois novos conceitos: o M-commerce e o M-advertising, respectivamente, comércio e propaganda pela mídia celular. Sua importância é ilustrada também pelo percentual de usuários da rede social Facebook. Segundo dados do site da empresa em novembro de 2011, a rede contava com mais de 800 milhões de usuários ativos, dentre os quais 350 milhões acessavam a rede por meio de seus celulares.

Barwise e Strong (2002, p. 15) realizaram estudo numa época em que havia poucos smartphones como os atuais que permitem ao detentor de um celular navegar na internet com uma velocidade tão boa quanto num desktop ou laptop. Há quase 10 anos, a maioria dos detentores de celulares os utilizava para chamadas e envio de mensagens. $\mathrm{O}$ público mais significativo eram os jovens entre 18 e 24 anos e $80 \%$ dos usuários revelaram passar ao menos uma mensagem por dia.

Mir (2011, p. 2) aponta que, apesar do aumento do uso da mídia celular, ainda são insatisfatórios os resultados de ações de comunicação por esta mídia no que tange à capacidade de influenciar atitude e intenção de compra dos consumidores.

Snader (2012) indica estudo mais recente relaizado pela Editora Abril sobre a classe C aponta que em decorrência da facilidade ao crédito, esta é a classe que mais consome conteúdo de celular, jogos e vídeos, por ser este seu primeiro recurso de acesso à internet. Outras classes sociais já possuem desktops ou laptops.

$\mathrm{O}$ acesso à internet por membros da classe $\mathrm{C}$ deve intensificar-se, uma vez que $25 \%$ dos consumidores planeja comprar um smartphone nos próximos 12 meses e $27 \%$ esperam comprar um tablet. 
De acordo com pesquisa realizada junto a 5000 usuários de tablets na Inglaterra, 35\% da amostra assiste a videos on demand em tablets e não mais no PC ou TV; $40 \%$ acompanham programação de TV nesta mídia em detrimento da TV e $60 \%$ dos donos de tablets efetuaram transações de $M$-commerce nesta mídia contra, $47 \%$ dos donos de smartphones (SHIELDS, 2011).

Segundo Barwise e Strong (2002, p. 18), a efetividade do M-advertising repousa na adoção de mensagens concisas, atraentes e com linguagem adequada ao público-alvo e seu conteúdo ser informativo ou com cunho de entretenimento.

Pesquisa realizada por Haghirian (2005, p. 261) concluiu que a atitude do consumidor frente à propaganda em celulares - M-advertising - é mais favorável e percebe-se mais valor quando o conteúdo é relacionado a entretenimento. Segundo o autor, a qualidade da mensagem também é essencial para melhor aceitação desta ação de comunicação.

Outro estudo realizado em 2007, nos EUA, por empresa especializada em métricas de comunicação de marketing digital, identificou que 64\% dos principais decisores liam emails em Blackberrys ou produtos similares. Nos últimos cinco anos, este percentual deve ter aumentado devido à maior sofisticação do smartphones em ternos de visualização de conteúdo, bem como ao aprimoramento dos sites que incorporaram recursos que permitem melhor visualização nesta mídia (EMAIL MARKETING METRICS, 2007).

\section{Eventos técnicos}

Segundo definição de Belch e Belch (2008, p. 523), “(...) eventos correspondem à modalidade de promoção de vendas em que uma empresa ou marca é ligada a uma atividade temática com o propósito de promover um produto ou serviço (...)”. Este evento pode ser relacionado a esporte, ser um concerto, uma feira ou um festival e foi tratado no tópico sobre patrocínio de evento.

Ogden e Crescitelli (2007, p. 30), apresentam definição um pouco distinta. Para os autores esta modalidade de comunicação complementar inclui feiras, congressos, seminários, shows, dentre outras ações e são classificadas em duas categorias. Os autores classificam eventos em duas categorias: eventos com orientação técnica e eventos destinados ao público geral. O primeiro grupo é voltado para a área técnica e de negócios do mercado B2B e é constituído por congressos e feiras. O segundo é 
voltado para o público em geral, incluindo consumidores, é adotado por empresas de produtos de consumo e tem impacto nos diversos públicos interessados. Alguns exemplos apontados pelos autores são torneios de surfe, rodeios, salão de automóvel, feira do livro, eventos musicais e exposições, que se se encaixam no tópico relativo a patrocínio e sobre os quais há variada produção científica.

Adotou-se o termo "evento técnico" para distingui-lo de evento patrocinado, descrito no item de patrocínio e do evento desenvolvido nas ações de advertainment, que serão abordados no respectivo tópico.

Sobre o primeiro grupo de eventos mencionado por Ogden e Crescitelli (2007, p. 24), apesar de envolver atividades tradicionais e amplamente difundidas pelas empresas, há uma literatura escassa sobre os eventos com orientação técnica.

Nos EUA, estimativa da empresa Veronis Suhler Stevenson relativa ao ano de 2005 apontava que haviam sido gastos em eventos desta natureza quase US\$28 bilhões (HERSCH, 2007).

Schulaka (2010, p. 8-9) indica que, segundo pesquisa realizada com 300 empresas em 2010, seminários figuravam entre as três ferramentas mais adotadas para identificação de potenciais clientes.

Hersch (2007) aponta que este tipo de evento propicia a oportunidade de encontro de pessoas numa situação favorável ao fechamento de negócios. Após o evento, deve ser feito o contato com clientes potenciais.

Good (2010, p. 58) recomenda que esta ação de comunicação seja planejada e propõe uma lista do que deve ser considerado no planejamento:

i) definição do objetivo do evento;

ii) plano de comunicação do evento, considerando identificação do público-alvo, convite, confirmação escrita, confirmação telefônica, agradecimento pela participação, comunicação para casos de ausência de convidados; 
iii) plano de produção - checagem das instalações, mensuração do local do evento frente ao público esperado; fluxo de acompanhamento da lista de convidados; checagem dos materiais e demais aspectos para a realização do evento;

iv) cronograma de cada etapa;

v) pós-realização do evento.

Não foram identificadas aplicações de eventos técnicos no setor de bancos. Provavelmente, isso se deve ao fato dos serviços prestados não envolverem informações técnicas.

\section{Marketing de relacionamento}

Última ferramenta de comunicação do grupo de ações complementares, marketing de relacionamento refere-se ao conjunto de esforços das empresas em desenvolverem relacionamento com seus clientes (VAVRA, 1993; GORDON, 1998, ZEITHMAL; BITNER, 2003), que envolve a retenção e é baseada na satisfação que possibilita a fidelização dos clientes.

Segundo Peppers e Rogers (1997, p. 125-126), devem-se dedicar mais esforços aos clientes que trazem maior valor à empresa. Este valor pode ser devido tanto ao faturamento, quanto ao fato de trazerem novos clientes ao sugerirem produtos de uma empresa.

De acordo com Ogden e Crescitelli (2007, p. 31), à primeira vista o marketing de relacionamento não estaria integrado ao conjunto das modalidades de comunicação, no entanto, propõem sua inserção, devido ao fato de a comunicação ser inerente ao processo de relacionamento e à importância da criação e manutenção de um canal de comunicação com clientes para a existência do marketing de relacionamento. Os autores ressaltam que, na prática, a estrutura e as ações de um programa de relacionamento não precisam ser desenvolvidos de acordo com as diretrizes da CIM, mas que a integração dos programas de relacionamento aos demais esforços de comunicação da empresa é fundamental para a eficácia da CIM. 
Schultz e Schultz (2003, p. 129) também consideram haver uma relação entre o marketing de relacionamento e a CIM, mas na dimensão do relacionamento do cliente com a marca.

Belch e Belch (2008, p. 578), relacionam o marketing de relacionamento ao estágio mais avançado de venda pessoal, no qual o vendedor busca desenvolver um relacionamento em que atua como um provedor de soluções.

Para Gummesson (2010, p. 23), o Customer Relationship Management (CRM) "representa os valores e estratégias do Marketing de Relacionamento com ênfase no relacionamento entre um cliente e um fornecedor (...)".

De acordo com Rosenwald (2005, p. 83), CRM é "o conjunto de uma série de ações e inciativas criadas para reforçar a decisão de compra inicial do cliente e manter sua relação com a empresa."

Segundo Rocha et al (2004, p. 6),

(...) para que haja uma comunicação focada no relacionamento, verifica-se nas características do Marketing Direto a relação intrínseca existente: interatividade - interação um a um, ou seja, é personalizado entre a empresa e o consumidor, utiliza, de forma integrada, uma ou mias mídias, obtendo um índice maior de resposta: mensuração da resposta: todas as ações podem ser mensuradas (...).

A ação de relacionamento é, portanto correlata ao marketing direto e relevante para o setor bancário, uma vez que os clientes pessoas física e jurídica de serviços financeiros tendem a desenvolver uma relação duradoura com os bancos.

ROCHA et al (2004, p.6) apontam haver uma relação entre manutenção e retenção dos clientes e sua satisfação com o produto ou serviço ofertado.

Em seguida serão apresentadas as ações de comunicação classificadas no grupo de "ações inovadoras", segundo classificação apresentada na Figura 3 (OGDEN; CRESCITELLI, 2007, p. 24). 


\section{Advertainment}

O advertainment é uma das formas de comunicação criadas recentemente e a primeira do grupo de ações de "comunicação inovadoras" (OGDEN; CRESCITELLI, 2007, p. 24).

Este tipo de ação de comunicação é um desdobramento de patrocínio exposto no item relativo ao tema. Drengner et al (2008, p. 138-139) indicam que uma restrição do evento patrocinado é a impossibilidade de passar muitas informações. Por outro lado, num evento em que é possível a participação da audiência e interação do público-alvo com a empresa, é viável passar mais informações e detalhes sobre produtos.

Os primeiros artigos sobre o tema datam da década de 1990 (COOK, 1990; KLAHR, 1999) e tratavam da ação como uma iniciativa de empresas em oferecer uma ação promocional que proporcionasse diversão a seus públicos-alvo. Cook (1990, p. 37) define que o advertainment tem como objetivo primário a propaganda e secundário o entretenimento.

Ogden e Crescitelli (2007, p. 32) explicam que o advertainment, tal como o nome sugere, remet à inserção de uma mensagem dentro de uma atividade de entretenimento. Trata-se de uma evolução da tradicional propaganda com um toque de diversão e pode ser adotada em programas de TV, filmes, eventos, jogos ou mesmo nos vídeos publicitários na internet (BELCH; BELCH, 2008, p. 256).

Nos últimos anos tem havido ações de advertainment em locais públicos como estações de trem, aeroportos e praças; um espetáculo de alguns minutos patrocinado por uma empresa é filmado e postado na internet, tornando-se um marketing viral, próxima ação do grupo de ferramentas de comunicação inovadora.

Os vídeos, uma das manifestações de advertainment têm importância na internet e têm maior chance de serem propagados devido a sua capacidade narrativa, bastante valorizada na Web (JENSEN, 2006, p. 361).

Para Belch e Belch (2008, p. 256), 
(...) aqueles que criam anúncios e outros conteúdos online observam que o melhor trabalho interativo deveria engajar o público sem exigir muito dele, ser contagiante, lembrar o público da promessa da marca e ser algo que os consumidores realmente procurarão. Devese dar ao consumidor os sentimentos de que ele está descobrindo sua própria experiência de entretenimento.

Na literatura há outras denominações, além de advertainment, para este tipo de ação de comunicação. Wohlfeil e Whelan (2006) e Drengner et al (2008) chamam de “marketing de eventos", Schmitt (1999), denomina "marketing experiencial" e Miloski (2005, p. 25) aponta a existência de “advergaming” voltado para o público entre 18 e 34 anos e que permite uma interação individual ou com um grupo.

Drengner et al (2008, p. 138) apontam que, nos últimos anos, o advertainment tem sido utilizado para descrever fenômenos diferentes, como eventos, produtos, promoções de vendas, ou patrocínios. Os autores sugerem sua adoção como ferramenta de comunicação com o objetivo de divulgar as mensagens de uma empresa, envolvendo os grupos-alvo em atividades experienciais, em linha com a classificação de Schmitt (1999).

Wohlfeil e Whelan (2006, p. 644) definem este tipo de evento de marketing como a "comunicação interativa de valores da marca que envolve uma situação hiper-real e tridimensional em que a marca e os consumidores estão ativamente envolvidos de forma a gerar um apego emocional do público com a marca".

Para Schmitt (1999, p. 85), este tipo de evento permite aos consumidores terem uma experiência com as marcas que vai além da observação ou audição do logo. Os participantes experimentam emoções e sentimentos que podem criar um vínculo. Este tipo de ferramenta de comunicação pode ser mais barato que propaganda e, dependendo do formato do evento pode gerar oportunidades de negócios ou até mesmo venda.

Em termos de origem, Wohlfeil e Whelan (2006, p. 645) identificam que esta ação surgiu na Alemanha no final dos anos 1980 em resposta a mudanças significativas na forma de comercialização e comportamento do consumidor, que passou a ser menos vulnerável aos apelos da propaganda e de outras ações de comunicação. 
Estes eventos de marketing são organizados pelas próprias empresas e podem concentrar-se em diferentes "objetos de evento", tais como marcas, linhas de produto, ou a própria empresa. Um exemplo de evento de marketing indicado por Drengner et al (2008, p. 138) é a série mundial de Red Bull Flugtag, organizada pela empresa fabricante de bebidas energéticas. Neste evento, os participantes saltam de uma rampa de máquina voadora em um lago, ação que expressa a mensagem publicitária "Red Bull revitaliza o corpo e a mente" por meio de uma experiência divertida.

Outro exemplo foi a apresentação de bailarinos numa estação de trem na Antuérpia ao som da música da película "A noviça rebelde", no $40^{\circ}$ aniversário do filme. O advertainment por ser um exemplo de marketing viral, pois, em pouco mais de dois anos, o vídeo postado no YouTube foi visto 22 milhões de vezes. (THE SOUND OF MUSIC - CENTRAL STATION ANTWERP, 2011).

\section{Marketing viral}

O marketing viral é uma modalidade de comunicação moderna do boca a boca com o diferencial de utilização da internet para a propagação da mensagem (OGDEN; CRESCITELLI, 2007, p. 32). Devido a sua rápida transmissão, foi feito um paralelo com o contágio de um vírus, que neste caso ocorre por e-mails, blogs ou redes sociais.

\footnotetext{
O marketing viral é uma forma de boca a boca online e pode se reproduzido por e-mail, vídeo, áudio, jogos, websites, redes sociais, fotografias ou documentos. Dentre estes, o mais usado para marketing viral é o e-mail, que pode transpor distâncias e atingir regiões remotas do mundo. (JENSEN, 2006, p. 360-361).
}

Antes de abordar o marketing viral, será feita uma explanação sobre o boca a boca. Dichter (1966, p. 166) publicou um dos primeiros artigos sobre o tema e apontou que, apesar da propaganda de massa ser suficiente para tornar um produto conhecido, estimular interesse e até vender, em alguns casos, quando há risco psicológico ou financeiro, a recomendação pessoal por meio do boca a boca exerce papel fundamental no processo de decisão de compra.

Feick e Price (1987, p. 83-84) apontaram que este tipo de comunicação interpessoal remonta a meados da década de 1950, quando foram publicados os primeiros estudos sobre o tema e propuseram a existência de consumidores que cumprem a função de 
market maven, ou sábios do mercado, para designar aqueles que têm conhecimento sobre tipos de produtos, tecnologias e locais onde podem ser feitas compras, mesmo não tendo adquirido o produto. Estes autores os distinguem dos "líderes de opinião", agentes que intervêm entre a mídia e a população.

Para Blackwell et al (2005, p. 422) o boca a boca é uma transmissão informal e amadora de comunicação de opiniões, ideias e informações entre duas pessoas, sem o envolvimento de nenhuma delas com funções de marketing do objeto da comunicação.

Segundo Bortoli e Campomar (2009, p. 3) os envolvidos no boca a boca podem ser usuários e não usuários, como amigos, familiares e líderes de opinião. Estes últimos são especialistas em uma determinada categoria de produto e seus julgamentos possuem considerável valor para novos consumidores.

Gladwell (2000, p.14) identificou além dos market mavens e líderes de opinião, dois tipos adicionais de propagadores do boca a boca: o conector e o vendedor. O primeiro tem a habilidade de ligar as pessoas que serão críticas à divulgação do tema do boca a boca e o último tem a capacidade de convencer ou vender aos outros sua ideia. $\mathrm{O}$ desafio para as empresa é identificar quem são os consumidores que exercem esses papeis. Com as redes sociais esta tarefa ficou um pouco mais fácil.

Em relação à origem, East et al (2011, p. 338) indicam que o boca a boca negativo é gerado por ex-clientes e consumidores que nunca foram clientes. O positivo, por outro lado, é provocado por clientes atuais.

Comparado à comunicação boca a boca, o marketing viral pode ter maior pode ter maior poder de persuasão e impacto, pois a comunicação pessoal tem mais credibilidade, dependendo da fonte. Por ser propagada por e-mail, a comunicação pode conter informações mais extensas, ser disseminada com mais rapidez e conveniência e multiplicar-se mais rapidamente e sem a pressão social presente numa comunicação face a face (PHELPS et al, 2004, p. 334-335).

Enquanto a comunicação boca a boca consiste na troca de palavras, numa situação face a face, o marketing viral costuma envolver a troca de experiências na forma escrita, o 
que pode ser uma vantagem, uma vez que cada pessoa pode absorver a informação no seu ritmo e no momento de preferência.

O termo word of mouse, traduzido para o português como marketing viral, foi criado por Steve Jurvetson e Tim Draper, em 1997 (KNIGHT, 1999). O marketing viral, ou boca a boca online, outra denominação para o boca a boca com uso da internet foi proposto por Sun et al (2006), que o definem como uma ferramenta para o estabelecimento de relações com as comunidades online. Os autores destacam que este tipo de comunicação oferece menos exibição pessoal, reduz a ansiedade social e permite maior facilidade para tratar de assuntos intimidadores.

A fim de regulamentar as práticas que envolvam a adoção do boca a boca, foi criada nos Estados Unidos, em 2004, a Word of Mouth Marketing Association (WOMMA). Esta entidade oferece a seus associados e ao público interessado, por meio do site, serviços como definições de ações de comunicação boca a boca, marketing boca a boca, buzz marketing e marketing viral. Também são oferecidos treinamentos, workshops, livros e compartilhados casos de boca a boca. Um dos temas tratados nos livros oferecidos na livraria da WOMMA é a medição do boca a boca.

Taylor (2005, p. 27) apresenta algumas definições da WOMMA, que distinguem boca a boca, marketing boca a boca, buzz marketing e marketing viral. $\mathrm{O}$ boca a boca é tido como "o ato de os consumidores fornecerem informação para outros consumidores". O marketing boca a boca é o caso de "dar às pessoas razões para falarem sobre seus produtos e serviços, facilitando a realização dessa conversa". Outra definição da WOMMA é a do marketing viral que é "a criação de entretenimento ou mensagens informativas feitas para serem passadas de forma multiplicadora, normalmente por meio eletrônico ou por e-mail".

\section{Buzz marketing}

Para Belch e Belch (2008, p. 12-14) o termo buzz marketing é usado para o que costumava ser chamado simplesmente de boca a boca e ambos pertencem ao grupo de marketing de guerrilha, os quais abrangem formas não tradicionais para alcançar os clientes. 
Segundo Ogden e Crescitelli (2007, p. 32-33) o buzz marketing assemelha-se ao marketing viral, por vezes sendo confundidos. O buzz da palavra buzz marketing é uma onomatopeia do zumbido que as abelhas fazem, referindo-se ao burburinho em torno de um tema que se torna relevante e sobre o qual as pessoas passam a falar.

De acordo com a WOMMA, o buzz marketing, consiste no "uso de entretenimentos notáveis ou notícias que levam as pessoas a falarem de sua marca". A principal distinção entre o buzz marketing e o marketing viral é que o primeiro pode ser difundido por meios convencionais como o boca a boca, não estando restrito à internet.

Para Ogden e Crescitelli (2007, p. 33), o marketing de guerrilha é uma variação do buzz. marketing e envolve o uso de ideias criativas a fim de atingir as pessoas de forma impactante em seus ambientes e não numa mídia tradicional ou internet.

De acordo com Belch e Belch (2008, p. 12),

(...) muitas empresas estão se voltando para uma estratégia discreta conhecida como buzz marketing por meio da qual a marca torna-se parte da cultura popular e os próprios consumidores são seduzidos para difundirem a mensagem.

A consolidação da internet e das redes sociais como meio de comunicação e relacionamento do século XXI, vem alavancando o buzz marketing, pois permite às empresas alcançarem muitas pessoas com baixo investimento.

Alguns autores reconhecem o buzz marketing online. Tao et al (2005, p. 27), referem-se às modalidade buzz online como Online Word-of-Mouth ou Online Word-of-Mouse (OWOM) e que o buzz seria gerado tanto pelos líderes de opinião quanto por quem busca informação online.

Niederhoffer et al (2007, p. 420) classificam esta ação de comunicação como pertencente à categoria de Consumer Generated Media (CGM) ou mídia gerada pelo consumidor. Em estudo realizado entre 2006 e 2007, estes autores identificaram que $85 \%$ das ações de buzz marketing em blogs estavam relacionadas a $10 \%$ dos lançamentos de bens de consumo ocorridos nesse período. Os autores também relacionaram o sucesso do buzz marketing a dois fatores: envolvimento do blogueiro 
com a categoria e investimento em propaganda, sendo este segundo aspecto mais importante que o anterior. Portanto uma conclusão desse estudo, é que a propaganda é importante para a geração de buzz marketing (NIEDERHOFFER et al, 2007, p. 425).

Segundo Khermouch e Green (2001, p. 52), buzz marketing ocorre quando a marca aparece disfarçada, tornando-se sutil, e quando os próprios consumidores se colocam como propagadores da mensagem. Para os autores, o que torna o buzz marketing atrativo é seu preço baixo e a credibilidade que os consumidores podem conferir à mensagem.

Tal como em qualquer comunicação pertinente ao grupo de ações de boca a boca, as comunidades na internet servem como um meio para os consumidores compartilharem suas experiências sobre um conjunto de produtos. No entanto esta mídia deve ser adotada com cuidado, pois o consumidor pode sentir-se traído ao perceber que está conversando com pessoas pagas por empresas para expressarem opiniões positivas sobre um produto (VRANICA, 2005, p. B9). Caso isso corra, devido à agilidade da comunicação na internet, será fácil começar um boca a boca negativo.

Segundo Bortoli e Campomar (2008, p. 9), é importante ressaltar que o uso da comunicação boca a boca, buzz marketing e marketing viral pelas empresas visa comunicar aos consumidores a existência das empresas, seus produtos e serviços. No entanto é difícil para as empresas controlar as mensagens disseminadas pelos internautas, sejam elas distorções de mensagens ou testemunhos desfavoráveis.

\section{Redes sociais}

Apesar de as redes sociais serem um desdobramento do marketing digital e representarem canais para outras decisões de comunicação de marketing como marketing viral, buzz marketing e advertainment, devido a sua importância nas relações e processo de comunicação entre consumidores e empresas, foi dedicado um tópico a esta ferramenta de comunicação de marketing e mídia.

Num momento da história em que inexistia a possibilidade de comunicação online e muito menos as redes sociais, Dichter $(1966$, p. 166) identificou que o consumidor 
desempenha um papel ativo no processo de comunicação de marketing por meio da troca de ideias, formulação de perguntas e respostas trocadas de maneira informal e com mais poder de influência do que a propaganda formal.

As redes sociais, junto de blogs e outros canais de comunicação online permitiram a intensificação do papel do consumidor na formação de opinião de outros consumidores a respeito de marcas e produtos. Há mais de 40 anos, o autor exortava os publicitários a identificarem e fornecerem aos geradores e influenciadores do processo de boca a boca informações favoráveis a seus produtos e marcas (DICHTER, 1966, p. 166).

No século XXI, as empresas estão investindo no mesmo processo, mas no mundo online, onde o papel e poder de influência dos consumidores são avaliados mais facilmente a partir da análise de seu perfil e número de seguidores. Apesar da importância das redes sociais na comunicação com o mercado, segundo estudo publicado recentemente (ANG, 2011, p. 32), ainda há poucas empresas que as adotam formalmente: menos de $7 \%$ das centrais de atendimento das empresas envolve redes sociais.

Batista (2011, p. 58-59) indica que, além de redes sociais digitais, há duas outras nomenclaturas vigentes na literatura: comunidades virtuais e mídias sociais. No entanto a autora propõe uma distinção entre as três:

Redes sociais: são representações estabelecidas na internet das relações e interações entre indivíduos de um grupo.

Comunidades virtuais: são grupos formados por indivíduos que compreendem e possuem um compromisso com um senso de valores, crenças e convenções que são compartilhadas entre si e que estabelecem uma relação que vai além do objetivo utilitário de uma particular interação, sem haver, necessariamente, uma interação face a face.

Mídias sociais: são ambientes disponibilizados na internet que permitem aos indivíduos compartilhar opiniões, ideias, experiências e perspectivas com os outros indivíduos. Essas mídias podem permitir tanto a construção das redes sociais como a construção de comunidades virtuais (BATISTA, 2011, p.61).

Segundo dados do Ibope Net Ratings publicados na revista Época (2010), as redes sociais mais acessadas pelo brasileiro em 2010, seguiam esta ordem: Orkut, YouTube, Twitter e Facebook. 
Conforme ilustrado no Gráfico 2, esta situação mudou em meados de 2011, quando, segundo dados do Ibope Nielsen Online (MARTINS, 2011), o Facebook assumiu a liderança entre as redes sociais mais acessadas no mercado brasileiro.

Estatísticas oficiais do Facebook em novembro de 2011, indicavam que a rede contava nesta ocasião com mais de 800 milhões de usuários ativos, dos quais $75 \%$ fora dos EUA, país de origem da rede. Um usuário médio do Facebook tinha 130 amigos e estava conectado a 80 comunidades, grupos ou eventos. Mais da metade de seus usuários acessa a rede a qualquer dia (FACEBOOK, 2011).

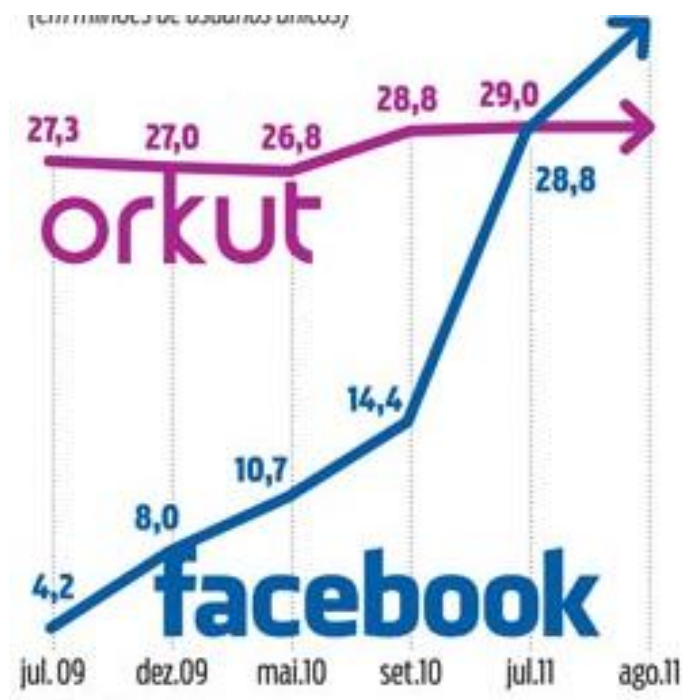

Gráfico 2 - Facebook supera Orkut no Brasil - número de usuários (MM) FONTE: MARTINS; 2011.

Ang (2011, p. 32) propõe que as empresas tratem as redes sociais como um canal de relacionamento com comunidades e sugere o conceito de Community Relationship Management (CoRM), uma vez que o que ocorre nas redes sociais não envolve exclusivamente clientes das empresas e suas motivações são, na maioria dos casos, de origem não comercial. O CoRM abarca a utilização de softwares de Customer Relationship Management (CRM) que viabilizem a gestão de informações sobre fóruns, relatos de clientes, blogs e wikis com os tradicionais sistemas de CRM.

Reichheld (2003, p. 51) indica haver três tipos de clientes: os promotores, os neutros e os detratores. Os promotores insistem para que seus amigos façam o mesmo. Os clientes neutros estão satisfeitos com os serviços ou produtos da empresa, mas pouco 
entusiasmados, podendo ser seduzidos pelo concorrente. As taxas de recompra e recomendação desse grupo são mais baixas que a dos promotores, muitas vezes inferior a 50\%. Os clientes detratores são consumidores infelizes que se sentem presos a uma relação ruim e são responsáveis por mais de $80 \%$ da propaganda negativa de uma empresa. Reichheld (2003, p. 53) recomenda que as empresas calculem sua taxa de netpromoter por meio da subtração do percentual de clientes detratores do percentual de clientes promotores. Por exemplo, se uma empresa possui $41 \%$ de clientes promotores e $32 \%$ de detratores, sua taxa de net-promoters será $9 \%$.

Para Kumar et al (2007, p. 140), a opinião do consumidor e o que ele está disposto a contar a outros consumidores sobre produtos e marcas têm impacto direto sobre vendas e lucros das empresas. Os autores indicam o exemplo da operadora de celulares Sprint, que oferece um crédito de US\$20 para todo cliente que referenciá-la para um cliente potencial. Os clientes potenciais que se tornarem clientes efetivos receberão um crédito de US\$10. De olho no potencial das redes, algumas empresas estão presentes no Facebook e Twitter e monitoram o comportamento do consumidor quanto a seus produtos e marcas. Da amostra entrevistada, todos os bancos estão presentes.

Wilson et al (2011, p. 23) alertam que as empresas devem avaliar seus clientes não somente por seu potencial de consumo e geração de receita, mas também por sua capacidade de influenciar o comportamento de compra de outros consumidores, distinguindo-os, por exemplo, pelo número de seguidores no Twitter. Por meio de um estudo sobre a estratégia de mais de mil empresas e 70 entrevistas com executivos, os autores identificaram que as empresas estão divididas em quatro estágios:

i) praticante preditivo, empresa cuja iniciativa de atuação em mídias sociais está restrita a um departamento específico, como atendimento a cliente;

ii) experimentador criativo, empresa que já começa a dar um passo no sentido de ouvir os consumidor e também seus funcionários nas mídias sociais;

iii) campeões de mídia social, exemplificada por empresas em que há iniciativas envolvendo diversas funções e níveis internos e que inclui parcerias externas; 
iv) transformador de mídia social, abordagem que permite interações em grande escala com diferentes públicos interessadas, tornando possível a adoção de práticas inesperadas.

É cada vez mais relevante a influência das referências no processo de decisão de compra. Dunningham (2011) menciona relatório da Berkeley, em parceria com o Boston Consulting Group, segundo o qual, 80 milhões de pessoas com idades entre 16 e 34, buscam ajuda de amigos e familiares para tomar qualquer decisão. Em termos de mídia - desktops, netbooks, smartphones e tablets - o usuário das redes sociais recorrem predominatemte à tecnologia móvel para receber opiniões e, antes de decidir, $68 \%$ dos entrevistados consultam primeiro sua rede social.

Kumar et al (2007, p. 143-144) propõem que, além de avaliar os consumidores, por seu CLV (Customer Life Value ou valor do cliente em seu ciclo de vida), as empresas calculem o Customer Referral Value (CRV) ou valor das recomendações que seus clientes podem gerar.

Por meio de pesquisa com quase 17 mil clientes de uma empresa de telecomunicações e outra de serviços financeiros, Kumar et al (2007, p. 143-144) identificaram quatro categorias de clientes, segundo seu CLV e CRV:
i) campeões,
ii) advogados ou promotores;
iii) avarentos;
iv) afluentes.

A mesma pesquisa indicou que estes clientes estão divididos segundo percentuais ilustrados na Figura 6. 


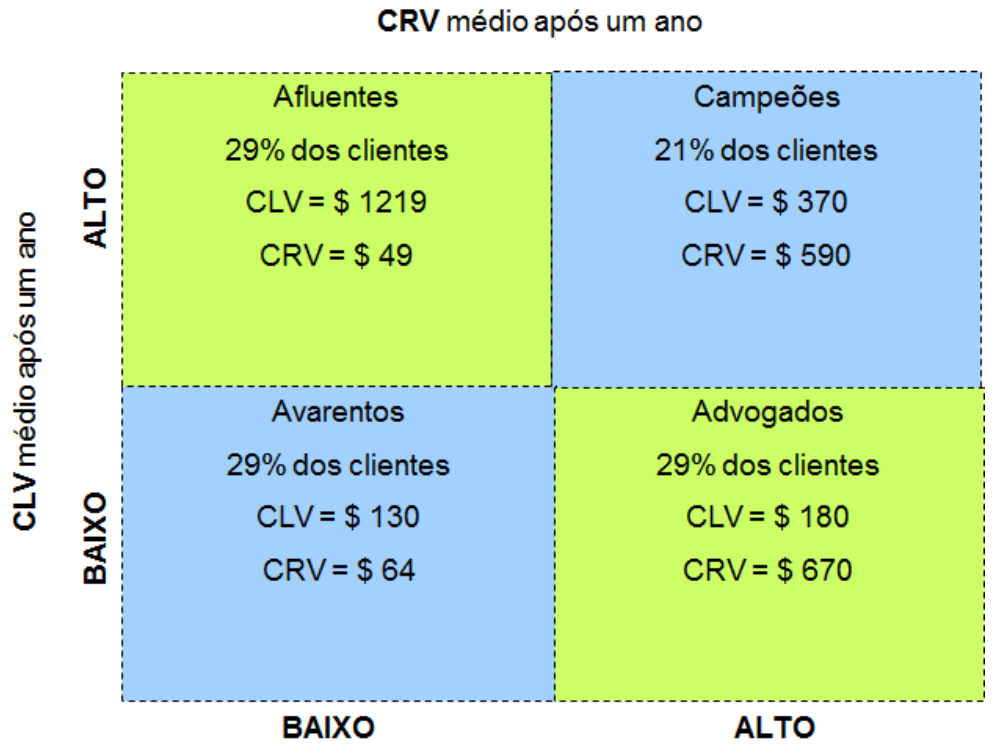

\section{Figura 6 - Matriz de valor do cliente}

FONTE: KUMAR et al; 2007; p. 144.

A partir da Figura 6, é possível observar que os clientes classificados como advogados são os com maior potencial de retorno por recomendação da empresa. É a estes clientes que as empresas devem dedicar esforços de comunicação e de monitoramento do que comunicam em suas redes de relacionamento.

Segundo Gupta et al (2011, p. 2-3), as redes sociais já atingiram status de mídia. Assim, sugerem que, antes de investir na mídia social, a organização conheça em profundidade suas particularidades para avaliar como inseri-la em sua estratégia de negócio e definir de que forma se engajará nela.

Conforme ilustrado na Figura 7, Gupta et al (2011, p. 3) apontaram cinco possíveis formas de as empresas estarem presentes e engajarem-se na mídia social. 


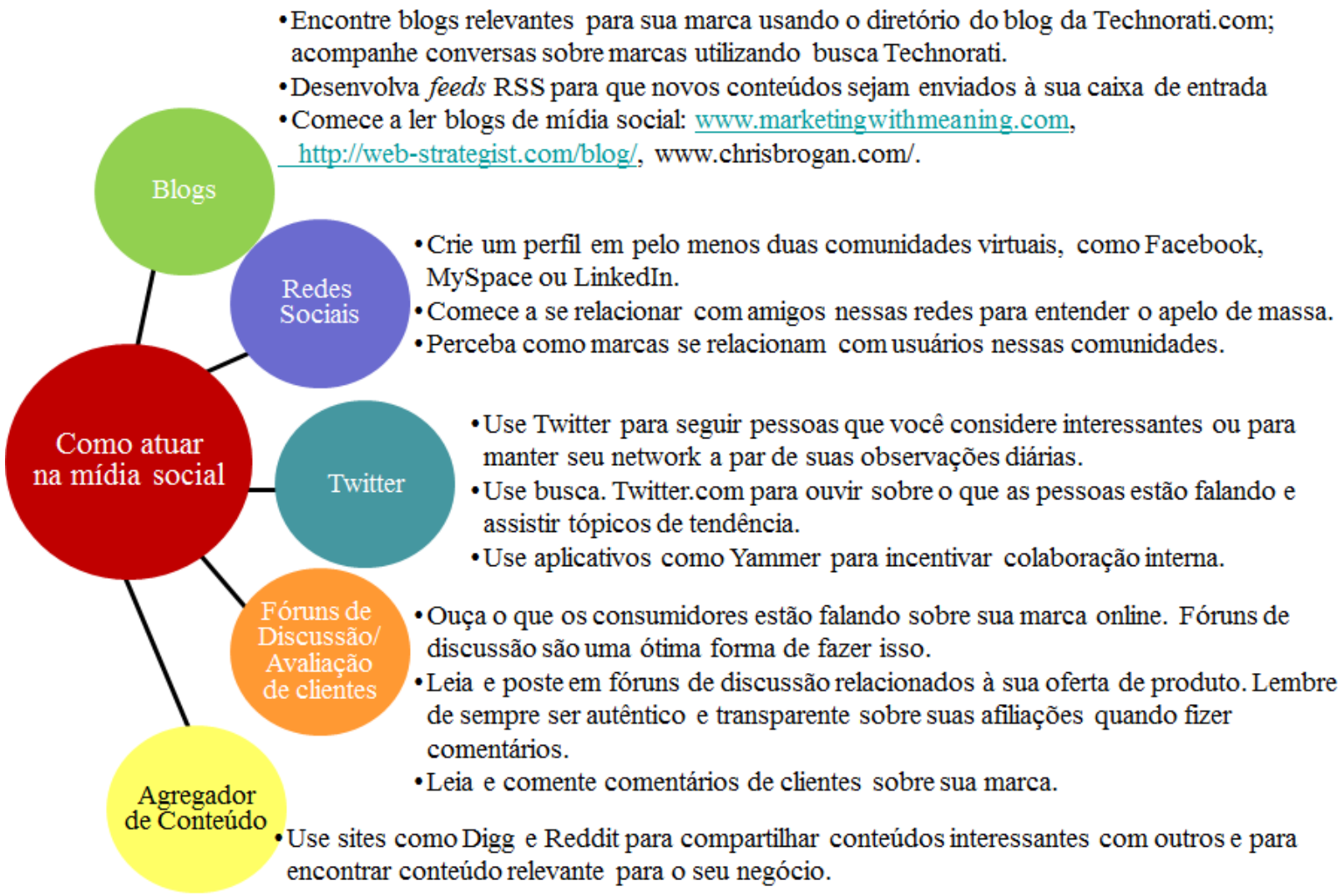

\section{Figura 7 - Formas de participação na mídia social \\ FONTE: GUPTA et al; 2011, p. 4.}

Para extraírem o máximo da mídia social, as organizações devem, num primeiro momento, aprender como ela funciona. Este aprendizado deve ser feito por meio de iniciativas que propaguem sua adoção e gerem a imersão de seus funcionários nesta mídia.

Gupta et al (2011, p. 4-6) apontaram vantagens de atuação na mídia social:
i) engajamento com o público;
ii) interação com a empresa;
iii) contínua pesquisa de mercado;
iv) contribuição de ideias para inovação de produtos;
v) personalização de campanhas digitais.

Como desvantagem, Gupta et al (2011, p. 3) indicam o risco de perda de controle da marca. 
Para avançar sua inserção nessa mídia, as empresas devem adotar ações que comecem com a criação de um perfil em redes sociais, passando pelo uso do Twitter para acompanhar o comportamento dos consumidores no universo online, pela identificação dos potenciais advogados ou promotores e dos detratores, pela interação com os clientes e, por último, devem procurar gerar conteúdo relevante para o negócio (GUPTA et al, 2011, p. 3-5).

Pesquisa realizada pela Oh! Pane! para o site Mercado Livre, em 2010, mostrou que $60 \%$ dos entrevistados pesquisam em mídias sociais antes de realizar uma compra, $79 \%$ considera que as opiniões postadas por amigos e conhecidos são as mais confiáveis, $73 \%$ admitem confiar mais na recomendação dos colegas do que em especialistas e $71 \%$ buscam comentários e recomendações de marcas, produtos e serviços que consideram adquirir. Segundo a mesma pesquisa (DUNNINGHAM, 2011), 25\% dos entrevistados seguem alguma marca em redes sociais para conhecer novas de ofertas de produtos e serviços $(79 \%)$ ou para buscar ofertas $(75 \%)$.

O Quadro 1 apresenta os diferentes elementos do mix de comunicação apresentados ao longo do item 1.1.1, suas características e as mídias ou meios de divulgação mais comuns a estas ações de comunicação.

Quadro 1 - Ações de comunicação de marketing

\begin{tabular}{|c|c|c|}
\hline $\begin{array}{l}\text { Modalidade de } \\
\text { Comunicação }\end{array}$ & $\begin{array}{l}\text { Principais Objetivos e } \\
\text { Características }\end{array}$ & $\begin{array}{c}\text { Mídia Usual de Divulgação e } \\
\text { Ações }\end{array}$ \\
\hline \multicolumn{3}{|c|}{ Ações de Comunicação Tradicionais } \\
\hline Propaganda & Criação de imagem e posicionamento & $\begin{array}{l}\text { Televisão, rádio, revista, jornal, } \\
\text { outdoor e cinema }\end{array}$ \\
\hline Relações Públicas & $\begin{array}{l}\text { Imagem na sociedade (opinião } \\
\text { pública) }\end{array}$ & $\begin{array}{l}\text { Televisão, rádio, revista, jornal, } \\
\text { outdoor, cinema e patrocínio de } \\
\text { evento }\end{array}$ \\
\hline Publicidade & Criação de imagem e posicionamento & $\begin{array}{l}\text { Televisão, rádio, revista, jornal, } \\
\text { outdoor e cinema }\end{array}$ \\
\hline $\begin{array}{l}\text { Patrocínio de } \\
\text { evento }\end{array}$ & $\begin{array}{c}\text { Criação de imagem, marca e } \\
\text { posicionamento junto ao público- } \\
\text { alvo e demais públicos interessados }\end{array}$ & $\begin{array}{l}\text { Televisão, rádio, revista, jornal, } \\
\text { outdoor, cinema, teatro, shows e } \\
\text { competições esportivas }\end{array}$ \\
\hline $\begin{array}{l}\text { Promoções de } \\
\text { Vendas }\end{array}$ & $\begin{array}{l}\text { Estímulo de vendas por meio de } \\
\text { benefício extra }\end{array}$ & $\begin{array}{l}\text { Ponto de venda, amostras, } \\
\text { cupons, brindes, sorteios, } \\
\text { concursos, descontos e } \\
\text { programas de fidelidade }\end{array}$ \\
\hline Marketing Direto & Contato personalizado & Correio, telefone e internet \\
\hline Venda Pessoal & $\begin{array}{c}\text { Mensagem personalizada, interativa e } \\
\text { modulada }\end{array}$ & Contato pessoal \\
\hline
\end{tabular}




\begin{tabular}{|c|c|c|}
\hline Product Placement & $\begin{array}{l}\text { Inserção de marca ou produto em } \\
\text { programas de TV e filmes }\end{array}$ & $\begin{array}{l}\text { Televisão, cinema e filmes na } \\
\text { internet }\end{array}$ \\
\hline Merchandising & Campanhas conjuntas e exposição & $\begin{array}{l}\text { Tabloide, encarte e ações no } \\
\text { ponto de venda }\end{array}$ \\
\hline Marketing Digital & $\begin{array}{l}\text { Flexibilidade, interatividade, rapidez } \\
\text { e baixo custo }\end{array}$ & Internet \\
\hline Evento Técnico & $\begin{array}{l}\text { Contato com público específico } \\
\text { (eventos técnicos) e público geral } \\
\text { (shows) }\end{array}$ & Feira, congresso e shows \\
\hline $\begin{array}{l}\text { Marketing de } \\
\text { Relacionamento }\end{array}$ & Contato individualizado com clientes & $\begin{array}{l}\text { Correio, telefone, internet e } \\
\text { contato pessoal }\end{array}$ \\
\hline \multicolumn{3}{|c|}{ Ações de Comunicação Inovadoras } \\
\hline Advertainment & $\begin{array}{c}\text { Combinação de mensagem com } \\
\text { entretenimento }\end{array}$ & $\begin{array}{l}\text { Televisão, internet e evento ao } \\
\text { vivo }\end{array}$ \\
\hline Marketing Viral & Evidência e destaque da mensagem & Boca a boca na internet \\
\hline Buzz marketing & Evidência e destaque da mensagem & Internet \\
\hline Redes Sociais & $\begin{array}{l}\text { Criação de imagem junto ao público- } \\
\text { alvo, opinião pública e } \\
\text { posicionamento. } \\
\text { Contato com públicos específicos e } \\
\text { contato individualizado com clientes }\end{array}$ & Internet \\
\hline
\end{tabular}

FONTE: Adaptado de OGDEN; CRESCITELLI; 2007, p. 35, a partir de conteúdo do tópico 1.1.1. (Ferramentas do mix de comunicação de marketing).

Devido à diversidade de ferramentas de comunicação disponíveis, de mídias, objetivos de comunicação e públicos-alvo do processo de comunicação de marketing de uma empresa, há algumas décadas, as empresas vêm dedicando esforços à integração das ações de comunicação para otimizar seus investimentos.

Um dos desafios para os profissionais de comunicação de marketing é integrar as diferentes ações, garantir a otimização dos recursos investidos e também a uniformidade da mensagem a ser transmitida. A integração das distintas ações é feita pela Comunicação Integrada de Marketing (CIM). O próximo tópico desta pesquisa abordará em que consiste a CIM, o papel que exerce para a implementação da estratégia de comunicação e como é aplicada.

\subsubsection{Comunicação integrada de marketing}

Para criar uma imagem diferenciada para um produto, marca ou empresa e alcançar vantagem competitiva sustentável, é necessário que o mercado perceba uma proposição de valor única e exclusiva. A comunicação desta proposição de valor pode ocorrer por 
diferentes fontes e mídias, conforme ilustrado na Figura 2 - Fluxo de Comunicação de Marketing.

\section{A CIM}

(...) é uma expansão do elemento de promoção (neste contexto, comunicação) do mix de marketing. Ela é essencialmente o reconhecimento da importância de comunicar a mesma mensagem para os mercados-alvo. Além disso, é o reconhecimento de que todas as suas variáveis comunicam algo e de que existe uma sobreposição na comunicação que essas variáveis fornecem. (OGDEN; CRESCITELLI, 2007, p. 3).

Segundo Kiely (1993 apud Kim et al, 2004, p. 32), os motivos para o surgimento e a propagação da CIM estariam ligados:

i) à redução da efetividade das mídias de massa, decorrente da fragmentação do mercado consumidor e enfraquecimento do poder da TV;

ii) à ampliação no número de canais devido à consolidação da comunicação digital;

iii) ao aumento no número e na diversidade de especializações das empresas responsáveis pela comunicação - RP, propaganda, promoção no ponto de vendas, etc.; iv) ao incremento na expectativa dos clientes anunciantes quanto a sua capacidade de melhor estimar a eficiência de seus orçamentos de comunicação.

Para Kim et al (2004. p. 40), a CIM visa evitar incoerências entre os diversos esforços de comunicação e aumentar a eficiência e o impacto numa maior audiência. Para os mesmos autores, a CIM enfrenta um desafio para sua implementação, devido à dificuldade de integrar atividades desempenhadas por diferentes agências responsáveis pela comunicação - RP, agências de propaganda, de promoção no ponto de venda. Acrescentam-se a esta variedade as agências especializadas em marketing digital.

Kerr et al (2008, p. 515) identificaram sete diferentes definições para CIM apresentadas no Quadro 2.

\section{Quadro 2 - Definições para a CIM}

\begin{tabular}{|c|c|l|}
\hline Fonte & Ano & \multicolumn{1}{|c|}{ Definição } \\
\hline AMA & 1989 & $\begin{array}{l}\text { Um conceito de planejamento de comunicação de marketing que } \\
\text { reconhece o valor agregado pelas agências de propaganda num programa } \\
\text { que integra uma variedade de ações estratégicas: propaganda, marketing }\end{array}$ \\
\hline
\end{tabular}




\begin{tabular}{|c|c|c|}
\hline & & $\begin{array}{l}\text { direto, promoção de vendas e relações públicas e as combina visando } \\
\text { clareza, consistência e o máximo de impacto. }\end{array}$ \\
\hline Schultz & 1991 & $\begin{array}{l}\text { O processo de gestão de todas as fontes de informação sobre produtos ou } \\
\text { serviços aos quais consumidores e prospects - potenciais clientes - são } \\
\text { expostos e como podem conduzi-los à compra e manter a lealdade do } \\
\text { consumidor. }\end{array}$ \\
\hline $\begin{array}{l}\text { Keegan et } \\
\text { al }\end{array}$ & 1992 & $\begin{array}{l}\text { A coordenação estratégica de todas as mensagens adotadas por uma } \\
\text { organização para influenciar de forma coletiva o valor percebido de uma } \\
\text { marca. }\end{array}$ \\
\hline $\begin{array}{l}\text { Kotler et } \\
\text { al }\end{array}$ & 1999 & $\begin{array}{l}\text { Conceito sobre o qual uma empresa integra cuidadosamente e coordena } \\
\text { os diferentes canais de comunicação para entregar uma mensagem clara, } \\
\text { consistente e atraente sobre a organização e seus produtos. }\end{array}$ \\
\hline Duncan & 2002 & $\begin{array}{l}\text { Processo multifuncional para a criação de relacionamentos duradouros e } \\
\text { lucrativos com consumidores e públicos interessados, por meio do } \\
\text { controle e influência das mensagens destinadas aos diversos públicos e } \\
\text { encorajando um diálogo com eles por meio de controle exercido } \\
\text { estrategicamente ou influenciando todas as mensagens enviadas a estes } \\
\text { grupos ou encorajando um diálogo com orientação para registro dos } \\
\text { dados. }\end{array}$ \\
\hline $\begin{array}{l}\text { Schultz e } \\
\text { Schultz }\end{array}$ & 2004 & $\begin{array}{l}\text { Processo de estratégia de negócio usado para planejar, desenvolver, } \\
\text { executar e avaliar programas de comunicação de marca coordenados, } \\
\text { mensuráveis e persuasivos para consumidores, clientes, prospects, } \\
\text { funcionários e associados e outros grupos relevantes externa e } \\
\text { internamente, ao longo do tempo. A meta é gerar retorno financeiro tanto } \\
\text { no curto quanto no longo prazo, construir a marca, bem como valor para } \\
\text { os acionistas no longo prazo. }\end{array}$ \\
\hline Kliatchko & 2005 & $\begin{array}{l}\text { Conceito e processo de gestão estratégica das decisões relativas aos } \\
\text { programas de comunicação de marca, tendo em vista conteúdo adequado } \\
\text { à audiência, mídia e orientação para os resultados ao longo do tempo. }\end{array}$ \\
\hline Kliatchko & 2008 & $\begin{array}{l}\text { Conceito e processo de gestão estratégica das decisões relativas aos } \\
\text { programas de comunicação de marca, tendo em vista conteúdo adequado } \\
\text { à audiência, aos públicos interessados, mídia e orientação para os } \\
\text { resultados ao longo do tempo. }\end{array}$ \\
\hline
\end{tabular}

FONTE: Adaptado a partir de KERR et al; 2008, p. 515.

Em 2008, Kliatchko (2008, p. 9) adicionou um pilar à sua definição de CIM de 2005 e apresentada no Quadro 2. Além de conteúdo adequado à audiência, mídia e orientação para resultados no longo prazo, o autor incluiu públicos interessados como fator a ser considerado na execução da CIM.

Posteriormente, num outro artigo, Kliatchko (2009, p. 12) salientou que, a despeito dos avanços na mensuração dos resultados dos programas de marketing e de CIM, os público interessados representam o pilar mais complexo da CIM. 
Segundo Schultz e Schultz (2003, p. 9-15), a ascensão da CIM foi motivada por alguns fatores:

i) a difusão da tecnologia digital ao longo de toda a operação;

ii) a ênfase dada à gestão das marcas como ferramenta de diferenciação competitiva;

iii) a intensificação do processo de internacionalização e a globalização das empresas;

iv) a Internet, que criou um novo canal de distribuição, comunicação e relacionamento e diversificou ainda mais as ações de comunicação.

Schultz (2004a) aponta as diversas tentativas de provar que programas de comunicação integrada trazem mais resultado que programas não integrados e para tanto, identificou cinco teses de doutorado e mais de 30 artigos desenvolvidos com o objetivo de indicar a importância da sinergia das ferramentas de comunicação de marketing para a efetividade da CIM.

Um caso bem sucedido foi artigo publicado por Naik e Raman (2003, p. 385), que, por meio de levantamento teórico e avaliação dos efeitos empíricos da sinergia de múltiplas mídias, comprovaram que, na prática, o impacto combinado de atividades multimídia, como televisão, revista, rádio, internet, marketing direto, promoção de vendas e RP pode ser muito maior do que a soma total de seus efeitos individuais. Os autores também propuseram um modelo de aplicação da CIM.

No que tange as funções da CIM, de acordo com Limeira (2005, p. 273), a formação da imagem para uma marca é um dos principais objetivos da CIM. A imagem de marca pode ser entendida como o conjunto de percepções, crenças, idéias e associações cognitivas ou afetivas que uma pessoa tem sobre um produto e que condiciona suas atitudes e seu comportamento de consumo. A construção de imagem e de personalidade para uma marca exige tempo, constância a consistência, o que reforça mais uma vez a importância da CIM.

O plano de marketing é fundamental para a efetivação da CIM e avaliação dos resultados atingidos. Belch e Belch (2008, p. 28-29) propõem um roteiro para garantir a efetiva aplicação e avaliação dos resultados de comunicação. Este roteiro envolve seis etapas: 
i) revisão do plano de marketing;

ii) análise da situação do plano promocional;

iii) análise do processo de comunicação;

iv) determinação do orçamento;

v) desenvolvimento do plano de comunicações integradas de marketing;

vi) monitoramento, avaliação e controle do plano de comunicações integradas de marketing a fim de buscar o alcance das metas e objetivos de marketing.

Não há unanimidade quanto à forma como as empresas adotam a CIM. Modelo desenvolvido em 1998 pela American Productivity and Quality Center (APQC) (apud Schultz e Schultz, 2003, p. 22-30), indica haver quatro estágios de adoção da CIM. O primeiro estágio de adoção da CIM envolve uma coordenação tática com ênfase na uniformidade da imagem e mensagem comunicadas. No segundo estágio há uma redefinição do escopo da comunicação de marketing e os profissionais de comunicação buscam incorporar insights dos consumidores em todos os pontos de contato com a empresa. No terceiro estágio, há uma aplicação efetiva da tecnologia como meio de obter informações de todos os segmentos atendidos para capturar uma visão mais precisa do relacionamento dos clientes com a marca. No quarto estágio ocorre uma integração entre a estratégia e os resultados obtidos por meio de um loop em que os resultados alimentem o planejamento da comunicação.

Ogden e Crescitelli (2007, p. 37-53) abordam como deve ser desenvolvido um plano de CIM. As etapas iniciais envolvem a declaração da missão e visão, histórico, análise interna e externa da empresa e avaliação do público-alvo. A segunda etapa trata das decisões estratégicas e neste ponto serão definidos os objetivos gerais da CIM. Estes objetivos devem obedecer a alguns aspectos: serem mensuráveis e quantificáveis, especificarem quem é o público-alvo, serem realistas, claros e integrados. A terceira etapa envolve as decisões táticas e envolve os objetivos específicos como, por exemplo, ser uma campanha institucional ou campanha de produto. A escolha da forma, ou seja, os elementos do composto do mix promocional e das mídias - meio, considerará as restrições de orçamento, bem como o público-alvo e objetivos. A quarta e última etapa do plano consistirá da avaliação dos resultados. Para tanto, as empresas aplicam diferentes métricas que serão apresentadas posteriormente neste estudo. 


\subsubsection{Plano de Comunicação}

Como toda função gerencial, a comunicação requer planejamento e gestão e este processo é orientado pelo plano de comunicações integradas, que segundo Belch e Belch (2008, p. 26) oferece: “(...) uma estrutura para o desenvolvimento, implementação e controle do plano de CIM da empresa (...). A comunicação de marketing não é nada mais do que uma parte e deve ser integrada a todo o programa e plano de marketing”.

O plano de comunicação exerce papel fundamental no processo de planejamento por permitir uma visão e controle mais específicos das ações de comunicação. A despeito do composto de marketing possuir outros 3 Ps, relativos a produto, preço e praça, ou distribuição, somente a comunicação tem um planejamento próprio e seu controle é exercido pela área de marketing nas organizações. Em algumas empresas é criada uma área específica para a gestão das decisões de comunicação. Dentre os elementos do composto de marketing, somente este é controlado integralmente por esta área funcional.

Belch e Belch (2008, p. 29) propõem uma estrutura para o plano de comunicação apresentada na Figura 8. 


\section{I - Determinação de metas}

II - Revisão

da situação

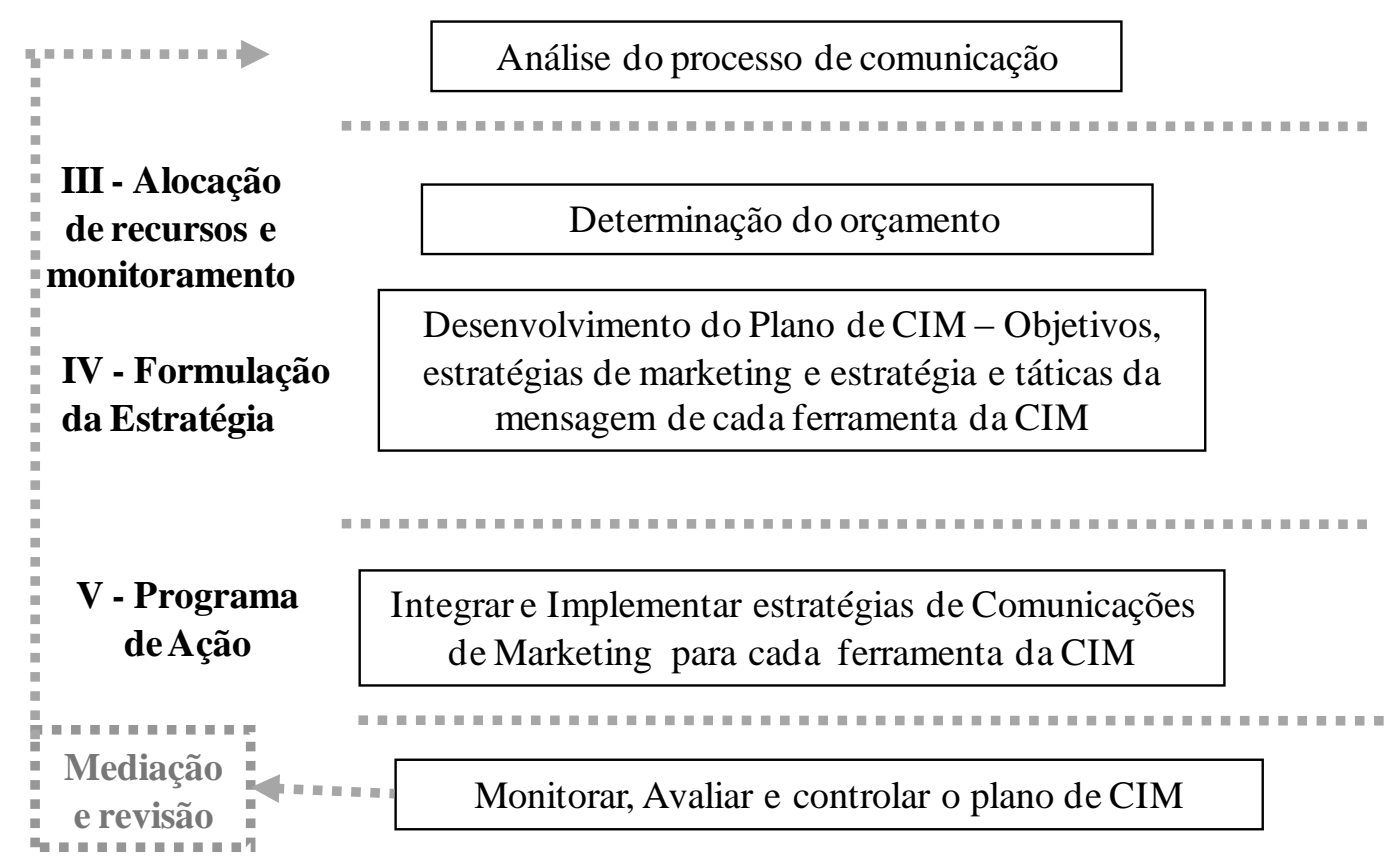

Revisão do Plano de Marketing

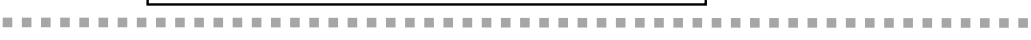

Análise da Situação do Plano

promocional

\section{Figura 8 - Plano de comunicação}

FONTE: Adaptado de BELCH; BELCH; 2008, p. 29.

De acordo com a Figura 8, as métricas de avaliação dos resultados da CIM deverão ser inseridas na etapa de V - Programa de Ação, em que ocorrerá a medição e revisão do plano de comunicação.

A adoção dessas métricas permitirá a avaliação da efetividade das ações de comunicação frente aos objetivos estabelecidos na etapa IV e o aprimoramento das ações futuras.

Para Shimp (2002, p. 55), a avaliação dos resultados das ações de comunicação é feita por meio do monitoramento do alcance dos objetivos previamente estabelecidos que, podem ser, por exemplo, geração de vendas de uma marca; gerar informação para intermediários - atacadistas, agentes e varejistas - e consumidores sobre melhorias da marca; construção de imagem de uma marca ou da empresa; incremento de fidelidade 
de clientes; anulação de uma propaganda ruim sobre a marca, gerar boa publicidade ou conter iniciativas de comunicação de marketing da concorrência.

A apuração do alcance dos objetivos estabelecidos na etapa de planejamento de comunicação é uma possível métrica de avaliação dos investimentos em comunicação. Portanto o uso de métricas exerce função fundamental no processo de gestão das decisões de comunicação de marketing e deveria fazer parte da rotina dos gestores desta área.

Shimp (2002, p. 49-50) propõe que as decisões de comunicação de marketing sigam um processo que percorre quatro etapas. Este processo está ilustrado na Figura 9 e nele a função fim da comunicação é o aumento do valor da marca,

Uma marca não tem valor se os consumidores não estão familiarizados com ela. Depois que os consumidores se conscientizam de uma marca, a intensidade do valor depende de como eles percebem suas características e benefícios, em comparação com as marcas concorrentes (SHIMP, 2002, p. 53).

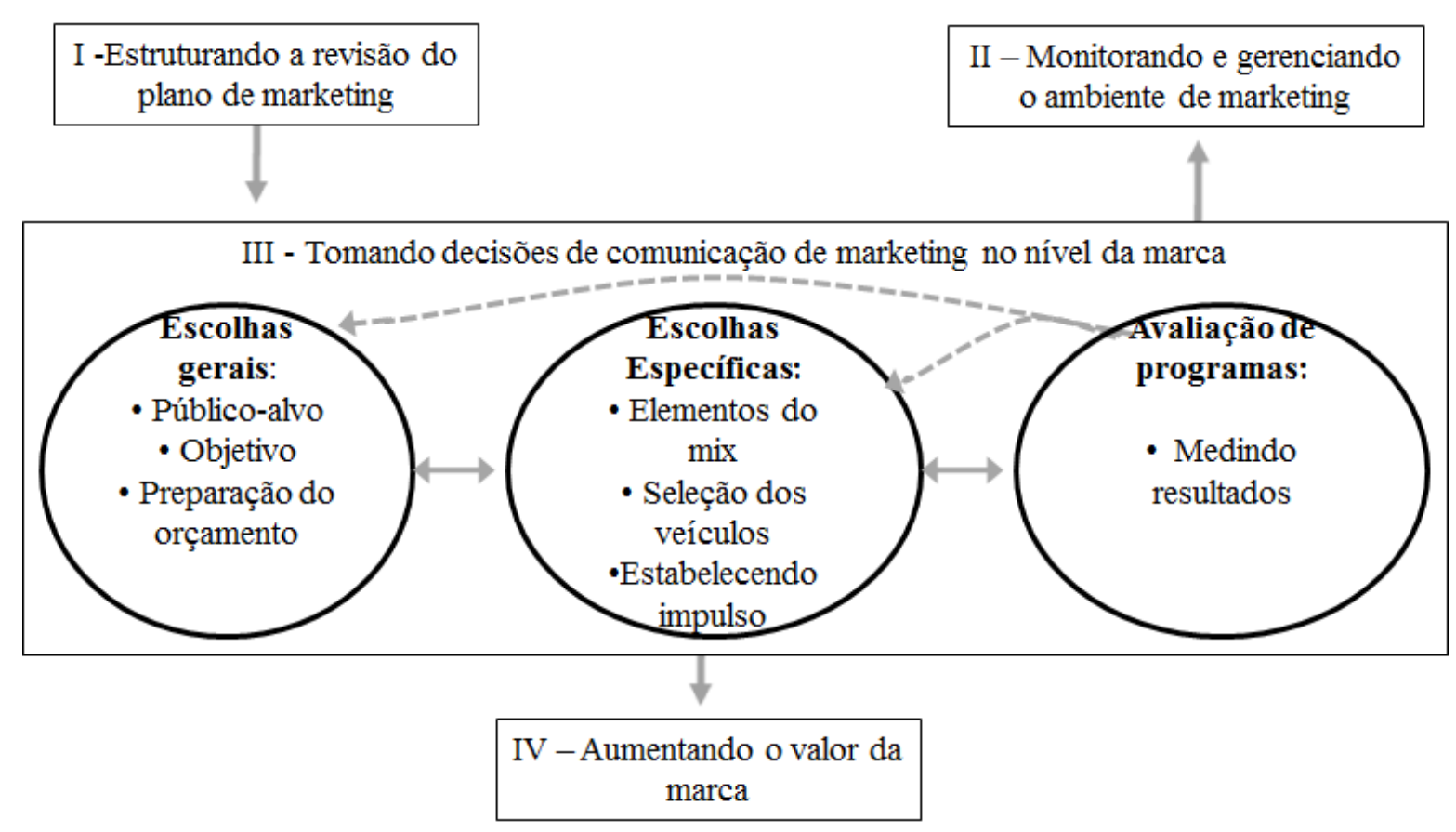

Figura 9 - O processo de decisão da comunicação de marketing FONTE: SHIMP; 2002, p. 50. 
A despeito do foco que o autor concede ao aumernto do valor da marca, sua posição não invalida a adoção de métricas de avaliação de resultados, por meio das quais monitorase o alcance dos objetivos específicos.

\subsubsection{Mídia}

O planejamento de mídia é o processo, por meio do qual, as empresas escolhem as mídias que serão adotadas e é uma das decisões mais complexas dentre as decisões de marketing. Um dos motivos para sua complexidade deve-se ao fato de envolver grande variedade de variáveis e possíveis combinações, pois considera além da categoria de mídia - TV, revista, jornal, internet, etc - , a escolha do veículo específico dentro de cada categoria, como um canal de TV, estação de rádio, revista, jornal ou site (SHIMP, 2002, p. 343-344).

De acordo com Shimp (2002, p. 345-357), a etapa de planejamento de mídia, inerente ao processo de decisão da comunicação de marketing apresentado na Figura 9 envolve quatro estágios:

i) selecionar o público-alvo para garantir exposições adequadas e evitar desperdícios;

ii) especificar os objetivos da mídia, tendo em vista aspectos como alcance, frequência, peso, continuidade e restrições de custo;

iii) escolher as categorias e veículos do plano de mídia;

iv) comprar a mídia.

Historicamente, a TV é a mídia de maior impacto e a mais cara em campanhas de massa. Nos últimos anos seu custo não parou de crescer. Na década de 1960, um anunciante podia atingir $80 \%$ das mulheres dos EUA com uma veiculação simultânea na CBS, NBC e ABC. No início do século XXI um anúncio teria que ser veiculado em 100 canais de TV para atingir o mesmo resultado (BIANCO, 2004, p. 61).

Na década de 1960, Brown (1967, p. 262-263) apontou que a seleção de mídia deveria considerar alguns aspectos, tais como as características do público-alvo da ação de comunicação vis-à-vis o perfil da mídia e o orçamento disponível. 
Segundo Belch e Belch (2008, p. 317-327) os indicadores de mídia mais usados para suportar o processo de decisão das mídias a serem adotadas no planejamento de mídia são:

i) cobertura do mercado-alvo e geográfica;

ii) alcance, relativo ao percentual de público-alvo ou número de indivíduos exposto a um método em particular, ao menos uma vez durante o período da campanha, que permite mensurar a amplitude da difusão de um comercial em uma população;

iii) frequência, que indica a taxa de exposição ou número médio de vezes que um indivíduo é atingido por uma propaganda durante determinado período, mas não necessariamente exposição ao anúncio;

iv) Exposição que permite identificar quantas vezes um comercial é visto. É uma função do alcance do comercial - número de pessoas que veem o comercial multiplicado pela sua frequência (número de vezes que veem). Farris et al (2007) e Shimp (2002) as chamam de Oportunidades de Ver (ODV) e indicam haver diferentes metodologias para cada tipo de mídia. Vale ressaltar a limitação quanto a sua capacidade de explicar a qualidade do que é visto;

v) Gross Rating Point (GRP) ou Target Rating Point (TRP), um percentual que corresponde ao número de exposições expressas em relação a uma população prépredefinida, ou exposições divididas pelo número de pessoas no público para uma campanha em diferentes veículos da mídia que transmitem um comercial ou campanha (SURMANEK, 1995, p. 23);

vi) Custo por Mil Exposições (CME) ou Custo por mil (CPM) indica o custo de propaganda por sua exposição junto a mil pessoas atingidas. Permite auxiliar a escolha das mídias na fase de planejamento e sua eficácia após a veiculação da campanha. Deve-se restringir seu uso a peças de uma mesma mídia, pois não é recomendado comparar o CME de um veículo com outro. (SENNA, 2003, p. 111). 
A diversificação das mídias e a fragmentação dos consumidores em grupos com necessidades mais específicas vêm mudando o perfil de gastos dos anunciantes. Em 1998, quase $95 \%$ dos gastos em propaganda eram destinados a mídias tradicionais como TV, jornal e revistas (SHIMP, 2002, p. 296). Kotler e Keller (2006, p. 575) apontaram que, em 2001, 56\% dos gastos em comunicação de marketing eram destinados a estas mídias.

A internet invadiu a vida do consumidor moderno estabelecendo novos padrões de comportamento. De acordo com Zigmond e Stipp (2010, p. 162), o americano médio acessa diariamente a TV e a internet, o que traduz a relevância da mídia digital na atualidade.

Colliander e Dahlén (2011, p. 313-314) propõem uma avaliação mais específica das diferentes formas de comunicação na internet. Os autores classificam os blogs como uma mídia com elevado potencial de influenciar o comportamento do consumidor, concorrendo com as revistas online e atuando tanto como uma mídia para propagação de boca a boca quanto para veiculação de propaganda e publicidade online.

A complexidade envolvida nas decisões de mídia impressa no Brasil é alta. De acordo com relatório anual do Instituto Verificador de Circulação (IVC, 2011), responsável pela auditoria da circulação de revistas, suplementos, jornais e websites, em 2010, havia 102 jornais e 355 revistas auditadas no Brasil. As revistas eram classificadas em 38 categorias que envolviam desde esoterismo, passando por ecologia, automobilismo a culinária.

Em termos de tendências de mídia, estudo publicado pela Advertising Age (2010) aponta que em populações relativamente pobres, a TV é considerada uma necessidade. $\mathrm{Na}$ Índia, em 2010, quase metade dos domicílios tinham uma TV, contra um terço dos lares em 2001. Nos centros urbanos, $96 \%$ dos lares possuem TV, contra 7\% de indianos que usam internet. No Quênia, a taxa de penetração de televisores saltou de $60 \%$ para $70 \%$ da população entre 2005 e 2009. Na periferia de São Paulo, as TVs são o bem mais vendido na rede varejista Casas Bahia, mesmo em áreas onde o abastecimento de eletricidade e água encanada é precário. 
De acordo com o mesmo estudo (Advertising Age, 2010), a despeito da disseminação da internet, assiste-se mais à TV. Em 2009, o norte-americano assistiu a mais de quatro horas e meia de TV por dia, apresentando ligeiro avanço - três minutos a mais - em relação à pesquisa realizada um ano antes. No resto do mundo, assiste-se, em média, três horas e 12 minutos por dia.

No que tange à mídia jornal, EUA e Europa perderam circulação de jornais nos últimos anos da primeira da década do século XXI. Ásia, África e América Latina aumentaram o número de títulos e circulação em dois dígitos. China e Índia abrigam quase metade dos 100 maiores jornais do mundo, com circulação média de 109 mil (Advertising Age, 2010).

Em relação à internet no mundo, o grupo de internautas com idade entre 8 e 18 anos, é o segmento de consumidores mais significativo. O tempo gasto por estes internautas quase triplicou na última década. A maior parte do tempo dedicado à internet é gasto em redes sociais, seguido de jogos online, sites de vídeos e instant messenger. O internauta pertencente a este grupo de jovens dedica em média sete horas e meia por dia à mídia internet. Em 10 anos, quando essas pessoas ingressarem efetivamente no mercado de trabalho, o consumo desta mídia deverá ser ainda maior (Advertising Age, 2010).

A fim de lidar com a complexidade de decisões de mídia, há tempos têm sido dedicados esforços para minimizar as dificuldades inerentes à tomada de decisão de mídia. Na década de 1960, Brown (1967, p. 262) propôs aplicar princípios de análise incremental para solucionar problemas relacionados à seleção de mídia impressa - revista, mais especificamente - e à escolha de campanhas de TV. Na ocasião da publicação do modelo proposto havia outros esforços para suportar a complexa escolha de mídias baseados em programação linear (BROWN, 1967, p. 262).

Nunes e Merrihue (2007, p. 63-65) apontam que a identificação de novas mídias que captem a atenção dos consumidores será um crescente desafio para os profissionais de comunicação de marketing. Tecnologias como o Digital Video Recorder (DVR) permitem aos consumidores selecionarem quais e quando querem ver comerciais na TV. 
A consolidação da internet e seu acesso por meio de desktops, laptops, tablets e celulares, conferem cada vez mais autonomia ao consumidor para escolher as campanhas a que deseja assistir. Os identificadores de chamada e a legislação brasileira também favoreceram a liberdade de escolha do consumidor, que pode evitar ligações indesejadas, bem como solicitar a exclusão de seu nome de mailings de telemarketing.

Kotler e Keller (2006, p. 57) indicam que a escolha da mídia deve considerar alguns aspectos:

i) hábitos de mídia do público-alvo;

ii) características do produto para identificação do que deve ser demonstrado;

iii) características da mensagem, conforme, por exemplo, o momento em que se deseja informar ao consumidor;

iv) Custo da mídia, tendo em vista o conceito de custo por mil - CPM, que permite a comparação entre as diferentes mídias.

O Gráfico 3 apresenta a penetração das mídias mais relevantes junto à população brasileira.

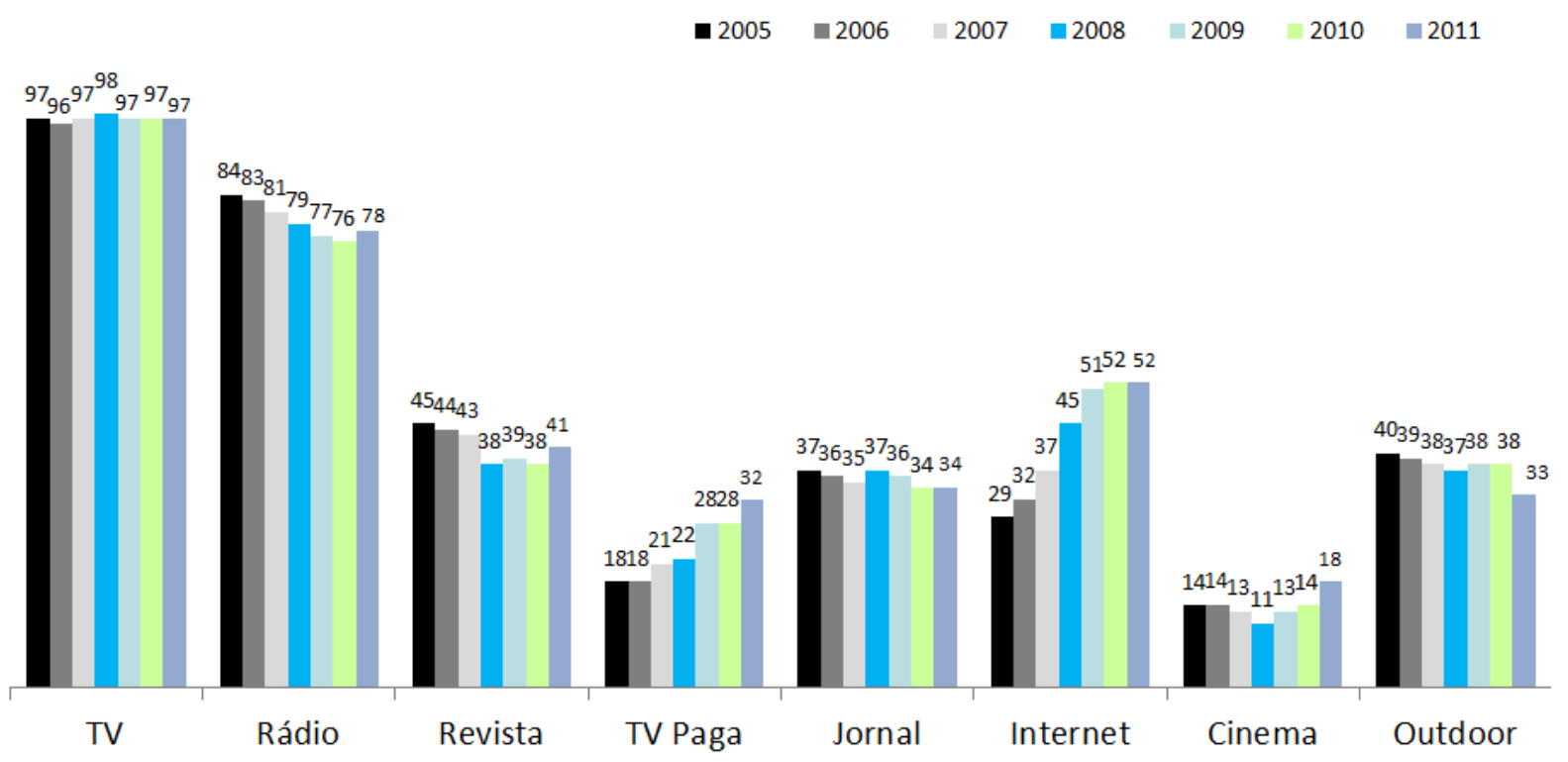

Gráfico 3 - Penetração de mídia na população brasileira FONTE: TARGET GROUP INDEX BRASIL; 2011. 
Segundo informações apresentadas no Gráfico 3, no Brasil, a TV é a mídia com maior penetração, seguida de rádio e revista. A internet ampliou em mais de 20 pontos percentuais sua penetração, sendo a terceira mídia com maior penetração, dentre as acompanhadas pelo Target Group Index (TGI) Brasil. Apesar da disseminação do uso de diferentes mídias de acesso à internet, esta pesquisa não resultados considerando acessos por tablet ou smartphone.

Para Ambler (2000a, p. 279-280), as mídias que envolvem o pagamento de uma comissão para agências de publicidade são denominadas above the line (ATL) e as demais below the line (BTL). As primeiras são mais massificadas, ao contrário das BTL que propiciam a adequação da mensagem a um nicho ou até mesmo com uma abordagem pessoal.

De acordo com Perloff (1993, apud LODA et al, 2005, p. 362), a importância da mídia no processo de planejamento da comunicação é tamanha que a mesma mensagem pode ser mais efetiva numa mídia do que em outra.

\subsection{Métricas}

Segundo Farris et al (2007, p. 15), uma métrica corresponde a,

(...) um sistema de mensuração que quantifica uma tendência, uma dinâmica ou uma característica. Em virtualmente todas as disciplinas, os praticantes usam métricas para explicar fenômenos, diagnosticar causas, compartilhar descobertas e projetar os resultados de eventos futuros. No mundo da ciência, dos negócios e do governo, as métricas estimulam o rigor e a objetividade.

Para Ambler,

as métricas devem ser necessárias, precisas, consistentes e compreensivas para objetivos de avaliação, podem ter origem financeira (como demonstrativo de lucros e perdas de uma gerência de produtos), origem no ambiente externo ou em fontes internas não financeiras (AMBLER, 2000a, p. 5).

As métricas são adotadas pelas organizações em diferentes áreas: estratégia, finanças, recursos humanos, compras, marketing, dentre outros. Na área de marketing fazem parte do plano de marketing no capítulo relativo a controle das ações e, mais especificamente, 
em comunicação, conforme mencionado no tópico 1.1.3, são inseridas no acompanhamento, avaliação e controle do plano de CIM.

Carton e Hofer (2006, p. 60) indicam cinco categorias de medidas de avaliação de desempenho organizacional. A primeira são Medidas Contábeis e envolvem informações identificadas a partir de relatórios financeiros, balanço e fluxo de caixa, tais como lucratividade, valores e razões que incorporam ganho líquido ou ganhos antes de imposto, crescimento e alavancagem, liquidez e medidas de fluxo de caixa (CARTON; HOFER, 2006, p. 60-74).

A segunda categoria trata de Medidas Operacionais não Financeiras, popularizadas por sistemas de medidas de desempenho, como o balanced scorecard (KAPLAN; NORTON, 1992) que representa a integração da estratégia com medidas de desempenho. Fazem parte deste grupo participação de mercado, mudanças em ativos intangíveis, conhecimentos e habilidades de recursos humanos, satisfação de cliente, inovação de produto, produtividade, qualidade e desempenho para stakeholders (CARTON; HOFER, 2006, p.75).

A terceira categoria de métricas é pertinente a Medidas Baseadas no Mercado e incorporam o valor de mercado da organização em termos de mudanças de razões e valores. Exemplos de medidas desta natureza são: retorno de investimento, valor agregado do mercado, Jensen's \& Tobin's $Q$. Estas medidas são criticadas por darem importância exagerada ao retorno do capital investido (CARTON; HOFER, 2006, p.7677).

A quarta categoria é pertinente a Métricas de Sobrevivência e indica se uma organização permaneceu no mercado conforme o tempo planejado e sua capacidade de sobrevier no futuro (CARTON; HOFER, 2006, p.78).

A última categoria trata de Medidas de Valor Econômico e são métricas que ajustam medidas contábeis tomando em consideração o custo do capital e a influência de regras financeiras impostas externamente. As medidas mais comuns são: i) ganho residual, desenvolvida pela General Electric e popularizada pela consultoria McKinsey como lucro econômico; ii) Stern Stewart Economic Value Added (EVA); iii) CFROI suportado pela da Holt Value e Braxton (CARTON; HOFER, 2006, p.79). 
Loshin (2005, p. 26) indica que boas métricas de desempenho de negócios devem ser: claras na definição; mensuráveis, relevantes para o negócio, controláveis, representativas, documentáveis, passíveis de acompanhamento e capazes de oferecer a possibilidade de serem analisadas a fim de sumarizar os resultados.

Dess e Robinson (1984, p. 268) propuseram que as métricas de avaliação dos resultados das empresas fossem classificadas em objetivas e subjetivas. O primeiro grupo refere-se aos índices de desempenho apurados numericamente, enquanto o segundo grupo inclui as medidas levantadas segundo a percepção de uma equipe de gestores. Os autores testaram hipóteses e a correlação entre as medidas dos dois construtos em relação às medidas de desempenho geral da empresa. Os resultados indicaram que as medidas subjetivas de desempenho não podem substituir as objetivas.

Venkatraman e Ramanujam (1986) contribuíram com o campo de estudo de métricas de desempenho de uma empresa ao indicarem três diferentes domínios para a avaliação de desempenho das empresas:

i) domínio de desempenho financeiro, que envolve métricas relacionadas ao crescimento de vendas, receita líquida e retorno aos ativos;

ii) domínio de desempenho financeiro e operacional, relativo ao desempenho do negócio, propriamente dito, abrange métricas de participação de mercado, de introdução de novos produtos, qualidade dos produtos, eficácia de marketing, valor agregado à produção e outras medidas relacionadas à eficiência tecnológica;

iii) domínio de eficácia organizacional.

Kohli e Jaworski (1990, p. 6) sugeriram uma abordagem a partir do conceito de empresas orientadas para o mercado desenvolvido por Webster (1988, p. 38). Segundo este autor, a chave para uma empresa ser orientada para o mercado repousa no sistema de avaliação de desempenho e de premiação do corpo gerencial.

Kohli e Jaworski (1990, p. 8) indicam que a orientação para o mercado envolve a criação dentro da empresa, de inteligência de mercado relacionada a:

i) necessidades atuais e futuras de clientes; 
ii) disseminação da inteligência de mercado entre os diversos departamentos da empresa;

iii) capacidade de resposta da empresa em relação ao mercado.

A partir da definição da inteligência de mercado, os autores estabeleceram diversas variáveis de comportamento dentro das empresas, analisando-as em relação ao processo de orientação do negócio.

Jaworski e Kohli num estudo posterior (1993, p. 64), encontraram uma correlação positiva entre os dois construtos - orientação para mercado de uma empresa e seu desempenho de negócios -, comprovando que, quanto maior a orientação para o mercado, maior seu desempenho. Todavia não foi possível constatar correlação positiva entre orientação para o mercado e participação de mercado.

Bonoma e Clark (1988, p. 2) distinguiram os primeiros estudos sobre desempenho de marketing em que este era equacionado pela produtividade da proposta de avaliação da qualidade dos programas de marketing dirigido para a estratégia. Ou seja, os autores propuseram uma transferência do foco de eficiência - retorno do investimento - para efetividade - alcance de metas estratégicas.

Narver e Slater (1990) incluíram dimensões adicionais ao campo de estudo do efeito da orientação para mercado sobre o desempenho dos negócios de Kohli e Jaworski (1990, p. 8).

Narver e Slater (1990, p. 32) abordaram a relação entre o estabelecimento de vantagens competitivas e orientação para o mercado e indicaram que esta consiste basicamente de três componentes - orientação para o cliente, orientação para a concorrência e coordenação interfuncional.

A inclusão da dimensão concorrência representou um avanço em termos da relação marketing/estratégia competitiva e acentuou a importância do termo "vantagem competitiva" desenvolvida por Narver e Slater (1990, p. 21-22). 
Ao comprovarem a relação entre orientação para o mercado e desempenho de negócios, Narver e Slater (1990, p. 21-22) sugerem para pesquisas futuras uma gama variada de dimensões a serem exploradas, tais como:

i) novas medidas de desempenho;

ii) estabelecimento de formas inéditas de se medir orientação para o mercado (Kohli et al, 1993);

iii) inclusão da dimensão societal do marketing;

iv) desenvolvimento de estratégias empresariais para aumento da orientação para o mercado (SLATER; NARVER, 1994; SLATER; NARVER, 1995).

Estudo posterior de Kokkinaki e Ambler (1999) sobre a relação entre desempenho de marketing, práticas de mensuração, orientação para o cliente e orientação para a concorrência demonstrou que a orientação para a concorrência parece ser um forte determinante de desempenho apenas quando considerado isoladamente.

Deshpandé e Farley (1998) testaram, por meio de um estudo com 82 gerentes de 27 grandes empresas americanas e europeias, a validade das escalas de medida de orientação para o mercado desenvolvidas anteriormente por Narver e Slater (1990), Kohli et al (1993) e Deshpandé et al (1993). Além de validarem as escalas numa esfera internacional, os autores propuseram uma nova escala, síntese das propostas anteriores, por meio da qual puderam estabelecer uma nova definição para o que é orientação para o mercado: “(...) conjunto de processos interfuncionais e atividades direcionadas à criação e satisfação de clientes através de um monitoramento contínuo de suas necessidades" (DESHPANDÉ; FARLEY, 1998, p. 226).

A área de conhecimento de orientação para o mercado tem contribuído para a identificação da relação entre as ações de marketing e o desempenho das empresas.

\subsubsection{Métricas de marketing}

Durante alguns anos o marketing foi tratado como uma área subjetiva, em que era importante a realização de investimentos, porém sem um rigor na avaliação dos 
resultados nem do retorno financeiro trazido por esses investimentos. Todavia, com a intensificação da concorrência, aumento dos gastos e maior expectativa em relação às despesas, os profissionais de marketing passaram a ser mais cobrados por justificarem os gastos gerados.

Para Lenskold (2003, p. 7), as empresas que conseguirem dominar métricas de marketing e gerenciarem de forma adequada os seus projetos de investimentos em marketing, terão um grande diferencial competitivo em relação aos concorrentes.

Os primeiros esforços no sentido de aplicar métricas em marketing foram de natureza econométrica e surgiram da década de 1950 com o intuito de identificar qual preço deveria ser atribuído a um determinado produto a fim de obter o melhor resultado financeiro. Estes estudos eram conduzidos por profissionais ligados às áreas de matemática e economia (TINBERGEN; 1951, apud CLARK; DIRKSEN; 1951; WOLD; JUREEN, 1953, apud BOSCHAN, 1953). A partir desse período, com a intensificação das mídias e da distribuição em massa a partir da década de 1950, os profissionais de marketing e as agências que os atendiam passaram a buscar formas de medir o retorno dos investimentos em propaganda e outras decisões de comunicação.

Na década de 1960, quando a diversificação dos canais de distribuição distanciava cada vez mais os fabricantes dos consumidores finais de seus produtos, surgiram duas abordagens para atender à busca de alternativas para a mensuração dos resultados. Lavidge e Steiner (1961) propuseram a primeira abordagem: a hierarquia de efeitos de comunicação. A segunda abordagem foi o modelo DAGMAR - Defining Advertising Goals for Measured Advertising response (COLLEY, 1961), ou definindo objetivos para a propaganda a fim de medir os resultados.

O modelo DAGMAR considera que o objetivo final da propaganda é fazer com que o consumidor percorra quatro níveis de entendimento de uma marca a partir de conhecimento até ação. No primeiro nível, "Conhecimento", o consumidor deve conhecer uma marca ou empresa. No nível seguinte, de "Compreensão", o consumidor entenderá em que consiste o produto ou serviço e os benefícios que oferece, diferenciando-o da concorrência. No próximo estágio, de "Convicção", o consumidor 
atingirá uma disposição ou convicção de adquirir uma marca e, no último nível, denominado “Ação", o consumidor tomará a ação de compra.

Para Belch e Belch (2008, p. 203-205), o modelo DAGMAR trouxe algumas contribuições à mensuração de resultados por defender a definição de um bom objetivo de marketing, o qual deve ser expresso em termos de tarefas concretas e mensuráveis, dentro de um intervalo de tempo e voltadas a um público-alvo.

Além destes modelos, as décadas de 1960 e 1970 foram marcadas por propostas de métricas financeiras, tais como lucro (SEVIN, 1965, apud CLARK, 1999; GOODMAN, 1970, apud DICKINSON; ROTHBERG, 1973) e alocação de custos (FEDER, 1965) e também métricas não financeira de participação de mercado (BUZZELL et al, 1975).

Na década de 1980 foram publicados estudos sobre métricas financeiras de fluxo de caixa (BUZZELL; CHUSSIL, 1985) e sobre a relação entre Profit Impact of Market Strategies (PIMS) e o Return on Investiment (ROI) (BUZZELL; GALE, 1987), bem como métricas não financeiras como participação de mercado (JACOBSON, 1988, p. 78), este último apontando situações em que aumento de participação de mercado não ocasiona melhoria no ROI, como no caso de empresas que atinjam mais retorno por atuarem em nichos de mercado.

No final da década de 1980 e início dos anos 1990 foram dados novos passos na direção de como avaliar os resultados de marketing. Day e Wensley (1988) relacionaram os índices de desempenho das empresas como o estabelecimento de vantagens competitivas, partindo do pressuposto de que vantagem competitiva é fundamental para o pensamento estratégico das empresas. Day e Wensley $(1988$, p.4) apontaram que, devido à disponibilidade e acompanhamento contínuo, os indicadores de efetividade de marketing e de vantagem competitiva mais adotados pelas empresas eram participação de mercado e lucratividade. Os autores sugerirem que estes sejam substituídos por métricas de satisfação e lealdade de cliente, que melhor refletem a reação do consumidor frente à posição competitiva da empresa.

A partir da década de 1990, a adoção de métricas tradicionais - como incremento de lucro, vendas e aumento de participação de mercado - passou a ser questionada. Este 
questionamento foi acompanhado por uma crise de credibilidade dos profissionais de comunicação de marketing. Sheth e Sisoda (1995a, p.18) apontaram estudo de 1993 da Coopers \& Lybrand realizado com 100 empresas líderes em seus mercados na Inglaterra. Os resultados indicaram uma perda de credibilidade dos profissionais de marketing, nos quais estão incluídos os que atuam em comunicação. Esta perda estava relacionada ao fato de as métricas predominantes apresentadas pela área serem crescimento de vendas e participação de mercado, resultados gerados não exclusivamente por ações de marketing.

Outro estudo da McKinsey também de 1993, citado por Sheth e Sisoda (1995a, p. 18), atacava algumas falhas dos profissionais de marketing e apontava a insatisfação dos CEOs quanto ao desempenho desta área.

Por último, Sheth e Sisoda (1995a, p. 18) apontam estudo da Booz Allen \& Hamilton, de 1994, que identificou que os gerentes de marca se beneficiavam de resultados que deveriam ser atribuídos à área comercial. A desfavorável perspectiva quanto à área de marketing e seus profissionais persistem no século XXI.

Doyle (2000, p. 19) reforça a perda de prestígio dos profissionais de marketing nas empresas e a atual crise vem intensificando a cobrança sobre a área. Estudo da Delloite, realizado em 2008, com mais de 200 empresas europeias com faturamento superior a 200 millhões de euros, apontou que em decorrência da crise, os orçamentos de marketing sofreram cortes e os profissionais desta área vêm sendo ainda mais cobrados em apresentar resultados.

Na década de 1990, quando começaram a ser colocadas em xeque as tradicionais métricas de avaliação de resultados de marketing, foram feitos diversos estudos e propostas de diversificação de métricas. Clark (1999); Debruyne e Hubbard (2000); Rust et al (2002); Ambler e Roberts (2008) e Gupta e Lehmann (2006) recomendaram a adoção de avaliação de marcas e Customer Life Value (CLV). Anderson e Sullivan (1993) e Fornell et al (1996), indicaram Satisfação e Lealdade do cliente como alternativa às métricas tradicionais e Barwise (1993); Aaker e Jacobson (1994); Aaker (1996a) e Keller (1993; 1998), apontaram Brand Equity como referência para a avaliação dos resultados de comunicação. A mensuração dos resultados atingidos por 
qualidade de serviços também recebeu destaque a partir dos anos 1990. Reichheld (1993); Heskett et al (1994) e Zeithaml, (2000) são alguns dos atores que contribuíram para este campo de pesquisa relacionado à qualidade de serviços.

Broadbent e Fry (1995) foram alguns dos primeiros autores a advogarem uma abordagem de avaliação de resultados da propaganda que fosse além de exposições. Seu racional repousava no fato de que ao longo do tempo os efeitos da propaganda se deterioram em decorrência da perda de memória do público, da exposição da concorrência e as experiências pessoais. Além disso, os autores defenderam que muitas propagandas têm orientação para a obtenção de resultados no curto e não no longo prazo. Em contraposição, propõem como alternativa à medição dos resultados a avaliação das ações das empresas detentoras das marcas.

Estudos mais recentes sobre a adoção de métricas que buscam resultados financeiros envolvem um conjunto mais amplo de variáveis de marketing, tais como a duração do impacto da comunicação e seus efeitos psicológicos sobre o comportamento do cliente (POWELL, 2002; LENSKOLD, 2003; AMBLER et al, 2004; SCHULTZ; SCHULTZ, 2003). Outra abordagem proposta por Doyle (2000) trata da dimensão de geração de valor para o acionista, ou como o autor denomina Value-based communication (VBC).

O Quadro 3 sumariza a evolução histórica das métricas de marketing.

Quadro 3 - Histórico das dimensões de métricas de marketing

\begin{tabular}{|c|c|c|}
\hline Referências para métricas & Período & Autores \\
\hline Estudos econométricos & Década de 1950 & $\begin{array}{l}\text { Tinbergen }(1951, \text { apud }, \text { CLARK; } \\
\text { DIRKSEN, 1951); Wold e Jureen } \\
\text { (1953, apud, BOSCHAN, 1953) }\end{array}$ \\
\hline $\begin{array}{l}\text { Hierarquia de efeitos } \mathrm{e} \\
\text { Modelo DAGMAR }\end{array}$ & $\begin{array}{l}\text { Décadas de } 1960 \\
\text { e } 1970\end{array}$ & $\begin{array}{l}\text { Lavidge e Steiner (1961) e DAGMAR } \\
\text { (COLLEY, 1961) }\end{array}$ \\
\hline Alocação de custos & Década de 1960 & Feder (1965) \\
\hline Lucro & $\begin{array}{l}\text { Décadas de } 1960 \\
\text { e } 1970\end{array}$ & $\begin{array}{l}\text { Sevin (1965, apud CLARK, 1999); } \\
\text { Goodman (1970, apud DICKINSON; } \\
\text { ROTHBERG, 1973) }\end{array}$ \\
\hline Participação de mercado & Década de 1970 & Buzzell et al (1975) \\
\hline Fluxo de caixa & Década de 1980 & Buzzell e Chussil (1985) \\
\hline $\begin{array}{lll}\text { Participação } & \text { de } & \text { mercado } \\
\text { (PIMS/ROI) } & & \end{array}$ & Década de 1980 & $\begin{array}{l}\text { Buzzell e Gale (1987) e Jacobson } \\
\text { (1988) }\end{array}$ \\
\hline
\end{tabular}




\begin{tabular}{|c|c|c|}
\hline $\begin{array}{l}\text { Satisfação e lealdade do } \\
\text { cliente }\end{array}$ & Década de 1990 & $\begin{array}{l}\text { Day e Wensley (1988); Anderson e } \\
\text { Sullivan (1993); Fornell et al (1996), }\end{array}$ \\
\hline $\begin{array}{l}\text { Avaliação de marcas e valor e } \\
\text { CLV }\end{array}$ & Década de 1990 & $\begin{array}{l}\text { Clark (1999), Debruyne e Hubbard } \\
\text { (2000); Rust et al (2002); Ambler e } \\
\text { Roberts (2008) Gupta e Lehmann } \\
(2006)\end{array}$ \\
\hline Brand Equity & Década de 1990 & $\begin{array}{l}\text { Barwise (1993) Aaker e Jacobson } \\
\text { (1994); Aaker (1996a) e Keller (1993; } \\
\text { 1998) }\end{array}$ \\
\hline $\begin{array}{l}\text { Resultados atingidos } \\
\text { qualidade de serviços }\end{array}$ & $\begin{array}{l}\text { Década de } 1990 \text { e } \\
\text { século XXI }\end{array}$ & $\begin{array}{l}\text { Reichheld (1993); Heskett et al (1994); } \\
\text { Zeithaml, (2000) }\end{array}$ \\
\hline $\begin{array}{l}\text { Comunicação baseada em } \\
\text { valor para o acionista }\end{array}$ & $\begin{array}{l}\text { Década de } 1990 \text { e } \\
\text { Século XXI }\end{array}$ & Broadbent e Fry (1995); Doyle (2000) \\
\hline $\begin{array}{l}\text { Efeito psicológico da } \\
\text { comunicação sobre o cliente }\end{array}$ & Século XXI & $\begin{array}{l}\text { Powell (2002); Lenskold (2003); } \\
\text { Ambler et al (2004); Schultz e Schultz } \\
\text { (2003) }\end{array}$ \\
\hline
\end{tabular}

FONTE: Elaborado pela autora

Observa-se no Quadro 3 que a partir da década de 1990 foram exploradas métricas de diferentes orientações, relacionadas a avaliação de marca, qualidade de serviços, satisfação dos clientes, CLV, valor para o acionista e Brand Equity. No século XXI tem havido um foco maior no efeito psicológico da comunicação sobre o cliente e em criação de valor para o acionista.

A seguir serão abordadas as diferentes maneiras de avaliação das métricas de investimentos em marketing.

\subsubsection{Classificação das métricas de avaliação de investimentos em marketing}

Na literatura científica foi possível encontrar diferentes critérios de classificação das métricas de investimentos em marketing.

Kokkinaki e Ambler (1999, p. 14) propuseram classificar as métricas de avaliação de resultados de investimentos em marketing em seis grupos:

i) métricas financeiras, que envolvem: a) volume de vendas; b) giro de estoque; c) contribuição de lucros; 
ii) métricas de mercado competitivo, tais como: a) participação de mercado; b) share of voice, que é a participação relativa de investimentos em propaganda em relação à concorrência; c) preço relativo dos investimentos; d) parcela de promoções;

iii) métricas relativas ao comportamento do consumidor, como: a) penetração; b) número de usuários; c) lealdade; d) ganhos/perdas; e) churn de clientes ou taxa de perda de clientes;

iv) métricas do consumidor intermediário, tais como: a) consciência; b) atitudes; c) satisfação; d) comprometimento; e) intenção de compra; f) qualidade percebida do consumidor intermediário;

v) métricas de troca direta com o consumidor final relativas a: a) distribuição; b) disponibilidade; c) lucratividade por cliente; d) satisfação; e) qualidade de serviços percebida pelo consumidor final;

vi) métricas de inovação, como volume de receita gerada por novos produtos ou serviços.

Jung e Robinson (2005, p. 32-33) classificam as métricas em hard e soft. A combinação de métricas soft e hard permite às empresas desenvolver uma base consistente de mensuração para o planejamento futuro.

Para Lavidge e Steiner (1961, p.59), uma das funções da propaganda é produzir vendas. Mas este não deve ser o único objetivo, a propaganda detém o poder de influenciar o consumidor ao longo de um processo de longo prazo que permite a passagem por três estágios: conhecimento, afetivo e comportamental.

Para Jung e Robinson (2005, p. 32-33), as métricas soft correspondem às medidas contábeis com foco financeiro, incluindo orçamentos, recursos humanos, aspectos relacionados a tempo, resultados, eficiência e desempenho de vendas.

O grupo de métricas hard envolve dimensões qualitativas relacionadas à motivação, preferências de clientes, expectativas, percepção, atitude e nível de satisfação. Para os 
autores, as métricas soft são indicadas para mensurar as cinco primeiras etapas do modelo de hierarquia de efeitos de Lavidge e Steiner - consciência, conhecimento, simpatia, preferência e convicção, conforme a Figura 10.

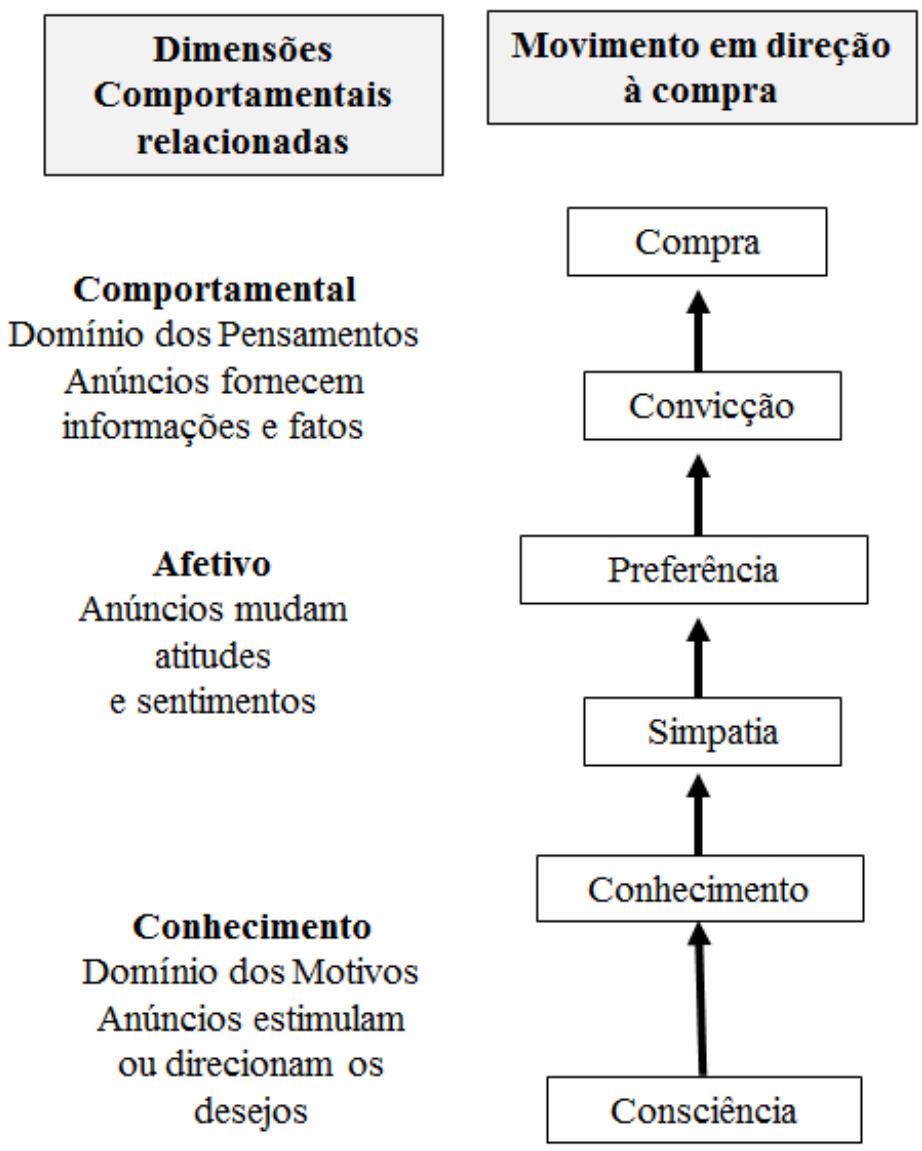

Figura 10 - Modelo de hierarquia de efeitos de Lavidge e Steiner FONTE: LAVIDGE; STEINER; 1961, p. 3.

Sobre a perspectiva de VBC proposta por Doyle (2000) e Guissoni e Neves (2011), os autores acrescentaram ser necessário distinguir a análise de criação de valor no curto prazo e no longo prazo.

A análise no curto prazo envolve uma medida financeira, ou seja, o ROI em comunicação em relação ao custo de oportunidade do capital da empresa. A dimensão de curto prazo também tem uma medida não financeira relativa ao sucesso das ações de comunicação junto ao mercado-alvo.

No longo prazo, a análise do valor também envolve medidas financeiras e não financeiras. A medida financeira trata da projeção do impacto dos investimentos em 
comunicação no valor presente líquido (VPL) de todos os fluxos de caixa futuros. A medida não financeira é relacionada aos ativos de marketing como brand equity e customer equity, ou valor do cliente (GUISSONI; NEVES, 2011, p. 39).

Farris et al (2007, p. 19) propuseram uma classificação baseada em 10 dimensões descritas na Figura 11.

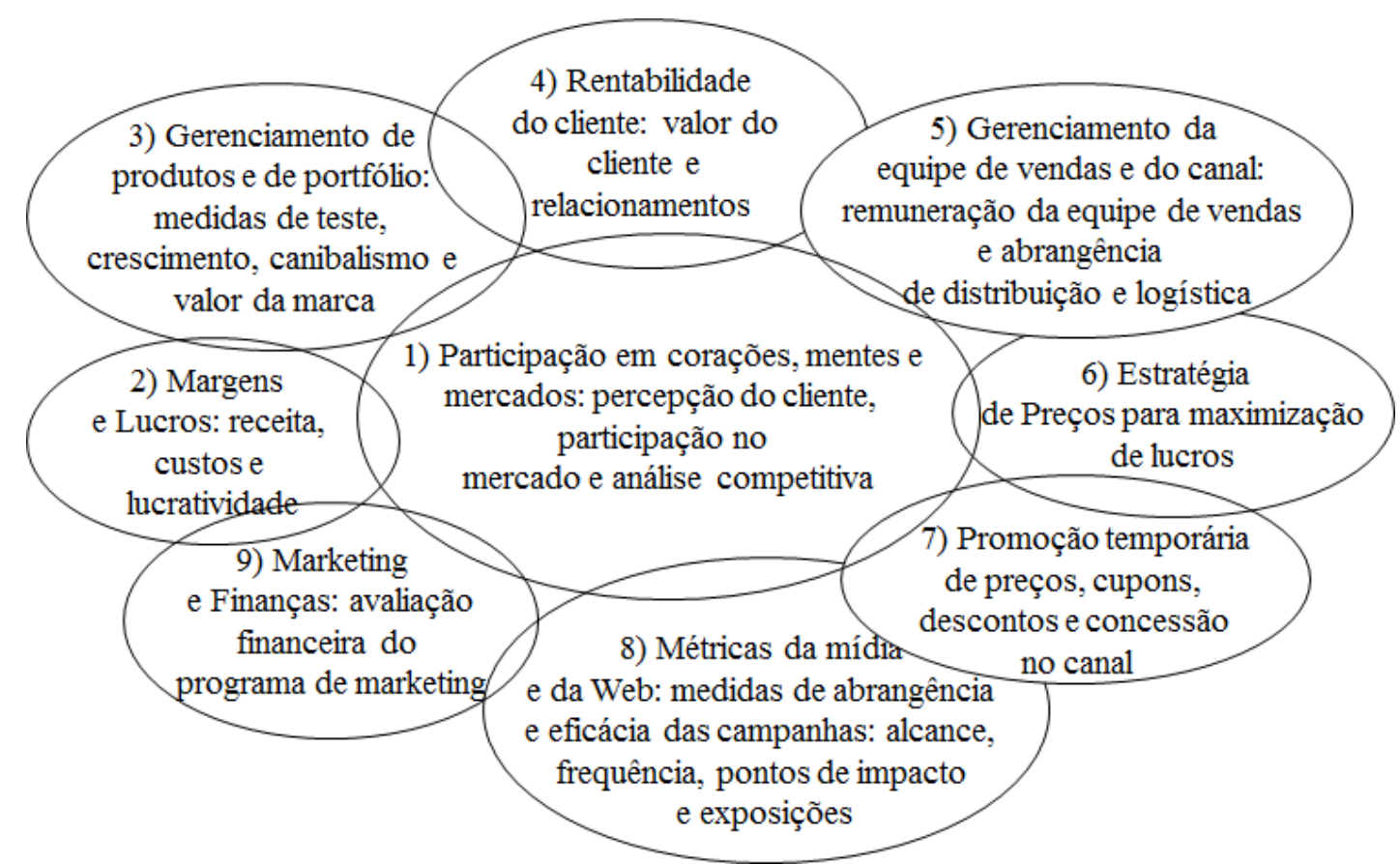

Figura 11 - Classificação de métricas por Farris et al FONTE: FARRIS et al ; 2007, p. 19.

Na abordagem de Farris et al (2007), as métricas foram identificadas e classificadas, tendo em vista a interação da área de marketing com as áreas de logística, operações, finanças e vendas.

A seguir será abordado como vêm sendo adotadas na prática as métricas de marketing desde a década de 1990. 


\subsubsection{Adoção das métricas de marketing a partir da década de 1990}

Na década de 1990, Ambler e Kokkinaki (1997, p.672) levantaram 150 artigos publicados entre os anos de 1991 e 1995 nas sete mais conceituadas revistas científicas de marketing e negócios e identificaram que as quatro métricas mais adotadas naquele período para avaliação dos resultados dos investimentos em marketing eram vendas e aumento nas vendas (47\%), participação de mercado (36\%); contribuição para os lucros (23\%) e intenção de compra (23\%). Esse estudo também apontou que 67,3\% das métricas eram financeiras e $32,7 \%$ não financeiras.

Apesar da proposta de novas alternativas de avaliação de resultados de investimentos em comunicação, Barwise e Farley (2004) realizaram estudo com empresas de cinco países industrializados cujos resultados indicaram que a maioria pesquisada $(79 \%)$ ainda utilizava como principal métrica de avaliação dos resultados a participação de mercado, ou seja, uma métrica relacionada a vendas, seguida de qualidade percebida dos serviços e dos produtos ofertados (77\%); e 40\% utilizavam ciclo de vida do cliente ou ciclo de vida de segmento.

Outro estudo realizado por Maddox (2006a) apontou ainda haver uma deficiência nas ferramentas de avaliação de resultados, indicando a existência de uma lacuna entre o que as empresas identificam como prioridade a ser medida e a adoção de processos para sua medição. Apesar de a maioria das empresas (71\%) priorizar o aumento de participação no mercado, $50 \%$ possuíam um processo que permitia avaliar esse resultado. Ainda neste estudo, 39\% priorizavam avaliar resultados por meio da ampliação da participação de negócios em seus clientes, mas somente $9 \%$ possuíam processo de aferição desse resultado.

Pesquisa do Chartered Institute of Marketing (CIM) indicou que menos de 50\% das empresas exigem a apresentação de métricas de marketing ao conselho e somente $7 \%$ têm KPIs (Key Performance Indicators) ou Indicadores-Chave de Desempenho (BARNETT, 2010). 
A adoção das métricas é recomendada com cautela por alguns autores. Aaker (1998, p. 12) indicou que o foco em avaliação dos resultados do curto prazo pode inibir a estratégia de longo prazo. Uncles (2005, p. 414-416) ressaltou que a área de marketing não deve estar subordinada ou controlada por contabilidade e finanças, com o risco de a adoção de métricas interferirem na criatividade inerente à área de marketing. Srinivasan e Hanssens (2009, p. 294) apontam que, por não serem especialistas em marketing, e terem foco no curto prazo, os investidores podem avaliar equivocadamente o impacto de uma decisão de marketing sobre os fluxos de caixa futuros e preterir uma estratégia que poderia dar certo devido ao foco em resultado. Afinal, segundo estes autores, os resultados das boas decisões de marketing são quase sempre intangíveis, como Brand Equity e lealdade do consumidor, e requerem tempo para serem atingidos.

\subsubsection{Adoção das métricas de marketing no Brasil}

No Brasil o tema métricas de avaliação de resultados é relativamente novo. Almeida (2007, p. 110) entrevistou 234 profissionais que atuam em marketing sobre seu conhecimento a respeito de 23 métricas de marketing levantadas numa fase exploratória preliminar da pesquisa em que foram identificadas as métricas mais adotadas. Os resultados da avaliação do conhecimento das 23 métricas indicaram que a satisfação dos clientes é a métrica mais conhecida (94\%), seguida por número de reclamações (92\%) e número de clientes (91\%). Os indicadores menos conhecidos no Brasil foram o VPL (52\%), ciclo de vida do cliente $(67 \%)$ e compras realizadas em promoções $(68 \%)$. No que tange aos indicadores menos conhecidos, mais da metade dos entrevistados tem familiaridade com as métricas e nove métricas são conhecidas por mais de $80 \%$ dos entrevistados. Menos de 20\% dos entrevistados conheciam todas as 23 métricas.

Outra pesquisa realizada com empresas brasileiras (QUEIROZ, 2008, p. 113) revelou que as métricas mais usadas são crescimento das vendas e vendas (95\% da amostra utiliza ambos). Os resultados dessa pesquisa também indicaram que as métricas financeiras são as mais utilizadas para mensurar o desempenho da área de marketing, sendo coletadas mensalmente por em $75 \%$ da amostra (QUEIROZ, 2008, p. 88). A frequência de uso de métricas é maior em empresas de grande porte, com faturamento superior a $\mathrm{R} \$ 600$ milhões ao ano e as fabricantes de bens de consumo (QUEIROZ, 
2008, p. 155). Foi possível constatar também que as empresas que adotam um sistema de avaliação de desempenho utilizam mais métricas (QUEIROZ, 2008, p. 125).

Pesquisa da Accenture, (2009) com associados da ABA (Associação Brasileira de Anunciantes) indicou que $30 \%$ da amostra pesquisada não media ROI de marketing. Dentre as métricas consideradas pela amostra, a avaliação de atributos da marca era a métrica mais adotada e $95 \%$ das empresas avaliavam atributos da marca.

Para Conceição (2011, p. 10), além dos anunciantes, as agências publicitárias vêm acompanhando a tendência de foco em avaliação dos resultados. No entanto, devido ao sistema de remuneração das agências baseado num percentual sobre o montante, estas não demonstram o mesmo interesse que os anunciantes em avaliar os resultados dos investimentos em comunicação.

Apesar de as agências publicitárias não atribuírem a mesma importância às métricas, segundo Conceição (2011, p. 10), o profissional de mídia, responsável pelas decisões de mídia de campanhas publicitárias, deve estar atento às novas métricas para avaliar o desempenho das mídias e poder entregar resultados ao cliente. De acordo com Conceição (2011, p. 10), "ele deve encontrar métricas que avaliem as novas ferramentas e que façam com que os clientes tenham conforto ao aprovar essa mídia”.

\subsubsection{Desafios à adoção de métricas de comunicação}

A busca de avaliação dos resultados dos investimentos em comunicação avança apesar de algumas restrições. Jung e Robinson (2005, p. 33) apontam que uma das restrições à adoção de métricas quantitativas ou métricas hard, como denominam é o medo da mudança demonstrado pelos profissionais de comunicação associado ao desconhecimento que estes profissionais têm sobre mensuração de resultados financeiros aplicados à comunicação.

Outro desafio é o fato de nem sempre ser possível estabelecer uma relação direta e precisa entre os diferentes investimentos em comunicação e os resultados atingidos. Por exemplo, não é possível garantir que 50\% de um incremento de $\mathrm{R} \$ 300$ mil nas vendas 
de um produto tenham sido provocados por gastos em patrocínio, 30\% por investimentos em publicidade e $20 \%$ por gastos em propaganda.

Miloski (2005, p. 18-19) aponta os elevados gastos necessários para mensurar os investimentos em comunicação tendo em vista a diversidade de ações e mídias disponíveis. Dependendo da ação da comunicação, o custo e o tempo necessários para a avaliação dos gastos podem não justificar os benefícios decorrentes da avaliação dos resultados. A despeito dos desafios associados à avaliação dos investimentos em comunicação, esta preocupação é cada vez mais presente entre os pesquisadores e também nas empresas.

Para Lenskold (2003, p. 7), há dois desafios para a implantação das métricas de marketing: a dificuldade em justificar a adoção de métricas e a inconstância nas verbas investidas a cada ano, o que compromete o controle do retorno.

Para Schultz e Schultz (2003, p. 198-199),

(...) há quatro motivos que dificultaram a mensuração dos resultados de comunicação no passado:

Caixa preta da comunicação, pois, como num jogo de telefone sem fio, a mensagem estava sujeita a diferentes interpretações e passível de gerar distintas atitudes. Por isso, o foco era medir nas ações, como compra e não nas mudanças de comportamento;

Tempo de reação - nem todo esforço de comunicação gera um resultado imediato, as mensagens provocam impactos no médio longo prazo, ao passo que incentivos geram resultados imediatos;

A fonte da mensagem ou incentivo - consumidores são expostos a uma grande quantidade de mensagens e incentivos de distintas fontes. Devido à dificuldade de dissociar o impacto de cada ação, a tarefa de avaliar cada esforço é árdua;

Variáveis que afetam a avaliação - há fatores que podem influenciar os resultados atingidos pelas ações de comunicação, como falta de produto, dificuldade de acesso aos pontos de venda, incompatibilidade entre o preço adotado no ponto de venda e o anunciado, dentre outros.

\subsection{Métricas do mix de comunicação offline e online}

Segundo Brady (2004), por muito tempo os profissionais de comunicação de marketing não conseguiam justificar gastos em comunicação com propaganda e eventos, sob a desculpa da necessidade de construção de marca. No entanto, essa situação começou a mudar na década de 1990 quando a recorrência ao uso de métricas de marketing surgiu na literatura científica norte-americana (SHAW; MAZUR, 1997; AMBLER, 2000b). 
Esta alteração ocorreu em função de alguns fatores como a transferência do foco no produto para o foco no valor da marca; a redução dos tradicionais efeitos de avaliações de atitude ou lembrança espontânea; o excesso de comunicação que provocou a saturação das campanhas (SCHULTZ; BARNES, 2001); o aprofundamento de pesquisas e métricas relacionadas à brand equity (AAKER, 1991; 1996b) e a posterior disseminação e aumento de importância de métricas relacionadas ao tema.

Conforme mencionado no tópico 1.1.3 relativo ao plano de comunicação, a avaliação dos resultados de comunicação corresponde à última etapa do plano de marketing: o processo de integração das ações de comunicação. Nesta etapa são medidos e avaliados os efeitos atingidos.

Para Ogden e Crescitelli (2007, p. 51), a avaliação dos resultados deve envolver os objetivos e indicar como eles serão atingidos. Os autores destacam o risco de a avaliação ser baseada em vendas, resultado influenciado pelo composto de marketing como um todo e não somente por um de seus itens. Neely (2002, p. 48) reitera as restrições de uso de vendas para avaliar os resultados de ações de marketing, mas com outra abordagem. Segundo este autor, a redução de preço do produto ou melhoria nas características do produto ou serviços também podem provocar aumento nas vendas.

Ambler et al (2004), Belch e Belch (2008), Farris et al (2007), Rosenwald (2005) e Shimp (2002) apontam a existência de diferentes métricas para cada elemento do mix de comunicação. O Quadro 4 apresenta as ferramentas do mix de comunicação consideradas nesta pesquisa, seus objetivos e grau de dificuldade de mensuração dos resultados.

Quadro 4 - Ferramentas do mix de comunicação, objetivos e dificuldade de mensuração

\begin{tabular}{|l|l|l|}
\hline $\begin{array}{c}\text { Elemento do mix de } \\
\text { Comunicação }\end{array}$ & \multicolumn{1}{|c|}{ Objetivos* } & Dificuldade de mensuração \\
\hline Propaganda & Criação de imagem & Alta \\
\hline Relações públicas & $\begin{array}{l}\text { Formação e manutenção de } \\
\text { imagem }\end{array}$ & Média/Alta \\
\hline Publicidade & Criação de imagem & Baixa \\
\hline Patrocínio de evento & Associação de imagens & Média/Alta \\
\hline Promoção de vendas & $\begin{array}{l}\text { Agrega benefício extra ao } \\
\text { comprador }\end{array}$ & Média/Baixa \\
\hline Marketing direto & Contato personalizado e interativo & Baixa \\
\hline
\end{tabular}




\begin{tabular}{|l|l|l|}
\hline Venda pessoal & $\begin{array}{l}\text { Contato presencial } \\
\text { e interativo }\end{array}$ & Baixa \\
\hline Product placement & Criação de imagem & Alta \\
\hline Merchandising & Exposição & Média/Alta \\
\hline Marketing digital & Contato personalizado e interativo & Baixa \\
\hline Eventos técnicos & $\begin{array}{l}\text { Criação de imagem, interação com } \\
\text { público e relacionamento }\end{array}$ & $\begin{array}{l}\text { Média para imagem } \\
\text { Baixa para relacionamento }\end{array}$ \\
\hline $\begin{array}{l}\text { Marketing de } \\
\text { relacionamento }\end{array}$ & Interação e fidelização & Baixa \\
\hline Advertainment & $\begin{array}{l}\text { Criação de imagem, experiência e } \\
\text { relacionamento }\end{array}$ & Média/Alta \\
\hline Marketing viral & Criação de imagem & Alta \\
\hline Buzz marketing & Criação de imagem & Média/Alta \\
\hline Redes sociais & $\begin{array}{l}\text { Criação de imagem, experiência e } \\
\text { relacionamento }\end{array}$ & $\begin{array}{l}\text { Média para imagem e } \\
\text { experiência } \\
\text { Baixa para relacionamento }\end{array}$ \\
\hline
\end{tabular}

*Foram considerados objetivos de comunicação e relacionamento

FONTE: Adaptado a partir de BELCH; BELCH; 2008, p. 15-23; SHIMP; 2002, p. 32; IKEDA; CRESCITELLI; 2003, p.5.

A seguir serão apresentadas as métricas de avaliação de resultados identificadas na fundamentação teórica para cada elemento do composto de comunicação considerado neste estudo.

\section{Métricas de Propaganda}

Apesar de, por muito tempo, os orçamentos de propaganda terem sido justificados por aumento em vendas, há alguns anos esta não é considerada uma métrica adequada e suficiente para a avaliação dos resultados de esforços de propaganda, pois vendas são influenciadas por outros fatores, como características do produto, sua disponibilidade, preço e ações da concorrência (KOTLER; KELLER, 2006, p. 581).

Conforme mencionado, algumas das primeiras métricas de comunicação surgidas na década de 1960 foram propostas por Lavidge e Steiner (1961), no seu modelo de hierarquia de efeitos apresentado da Figura 12.

Segundo o modelo de hierarquia de efeitos, o consumidor passa por diferentes estágios ao longo da primeira etapa do processo que é consciência de uma oferta até a decisão de 
compra da mesma. Segundo a Figura 12, os autores propõem a adoção de distintas ações de promoção ou propaganda ao longo desse processo e formas de avaliação. As pesquisas constantes da quarta coluna da Figura 12 são exemplos das maneiras de mensuração dos resultados adotadas pelas empresas na década de 1960 (LAVIDGE; STEINER, 1961, p. 3). Portanto pesquisas de lembrança (recall), consciência (awareness), preferência, intenção de compra e apuração do resultado de vendas, consistem em métricas de avaliação de propaganda.

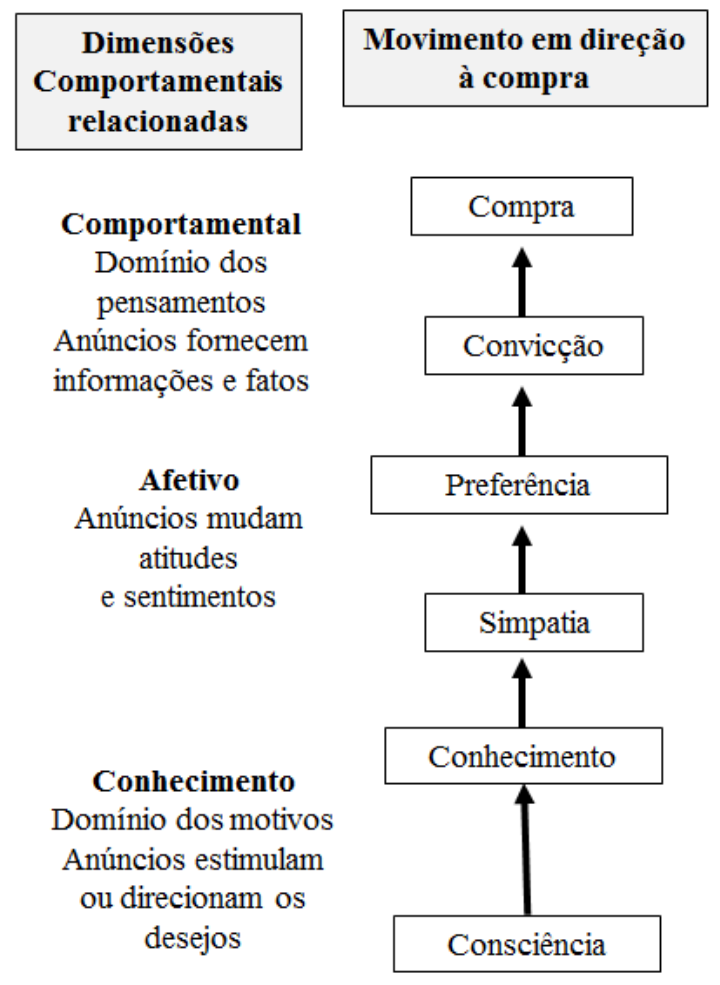

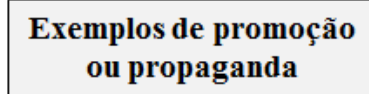
ou propaganda

$$
\begin{gathered}
\text { Pontos de venda } \\
\text { Anúncios de promoção } \\
\text { Promoções } \\
\text { Ofertas de último momento } \\
\text { Apelo de preço } \\
\text { Testemunhos }
\end{gathered}
$$

Anúncios comparativos Abordagens argumentativas

Abordagens de "imagem" Apelos de status e glamour

$$
\begin{gathered}
\text { Anúncios } \\
\text { Classificados } \\
\text { Slogans } \\
\text { Jingles } \\
\text { Propaganda aérea }
\end{gathered}
$$$$
\text { Teaser }
$$

Exemplos de pesquisa para avaliação

Vendas ou teste de mercado Testes split-run ${ }^{1}$

Intenção de compra Técnicas projetivas

Preferência por marcas Escalas

Medidas de imagem diferencial semântico e listas

Técnicas Projetivas

Perguntas Análise de Play back ${ }^{2}$

Pesquisa de Consciência e Recall

${ }^{1}$ Split-run corresponde à técnica de teste de avaliação de duas alternativas de comunicação (TOFFLER; IMBER, 1994, p. 494).

${ }^{2}$ Play back é um tipo de pesquisa qualitativa de avaliação de uma campanha (TOFFLER; IMBER, 1994, p. 405).

\section{Figura 12 - Propaganda e pesquisa de propaganda aplicada ao modelo de hierarquia de efeitos FONTE: LAVIDGE; STEINER; 1961, p.3.}

De acordo com Farris et al (2007), Belch e Belch (2008), Shimp (2002) e Ogden e Crescitelli (2007), algumas métricas significativas para avaliação dos resultados de propagandas são consideradas ainda na etapa de planejamento quando a partir da análise do público-alvo, serão escolhidas as possíveis mídias a serem adotadas. As métricas consideradas na etapa de definição de mídia são Alcance, Frequência, GRP, CPM ou CME. 
Tendo em vista que um dos objetivos da propaganda é aumentar a lembrança de uma marca e que o interesse do consumidor por uma campanha gera interesse em buscar informações adicionais na internet, Zigmond e Stipp (2010, p.162) sugerem que campanhas offline com este objetivo sejam avaliadas por meio das buscas online nos dias seguintes ao início da campanha. Dessa forma é possível identificar o interesse do público internauta pela campanha offline.

Aaker (1996b, p. 10) indica três métricas para avaliação de conhecimento da marca:

i) awareness, ou consciência da marca;

ii) recall, que corresponde à lembrança da marca;

iii) top of mind, que vem a ser a marca mais lembrada numa categoria de produto ou serviço.

Apesar de Cobra (2000, p. 198-199) indicar a importância da propaganda na comunicação, o autor propõe que a avaliação dos investimentos de comunicação seja feita considerando o esforço integrado de marketing institucional com foco no desempenho da marca,

O sucesso de uma empresa é medido por suas vendas, pelo lucro alcançado, pela participação de mercado e, sobretudo pela sua imagem em cada mercado em que atua. (...) Dentre os parâmetros de desempenho possíveis para avaliar o desempenho institucional de uma marca, destacam-se, entre outros os seguintes: o grau de respeito e admiração pela instituição aferido por meio de pesquisa de mercado; a imagem da instituição financeira frente a seus principais concorrentes e o grau de respeito e admiração pela instituição dos clientes internos (funcionários).

Segundo perspectiva de VBC proposta por Doyle (2000) e Guissoni e Neves (2011), no curto prazo, as empresas consideram uma medida não financeira relativa ao sucesso das ações de comunicação junto ao mercado-alvo e no longo prazo, adota-se como medida financeira o impacto dos investimentos em comunicação no VPL de todos os fluxos de caixa futuros e, como medida não financeira, brand equity e customer equity (GUISSONI; NEVES; 2011, p. 39). 


\section{Métricas de relações públicas}

As ações de Relações Públicas (RP) objetivam desenvolver uma percepção favorável à empresa e podem ser proativas, quando alinhadas aos objetivos de marketing da empresa, ou reativas, quando adotadas para responder a influências externas que impactem negativamente na imagem da marca ou oferta (SHIMP, 2002, BELCH; BELCH, 2008).

Belch e Belch (2008, p. 555-556) indicam algumas métricas de RP aplicáveis tanto a esforços proativos quanto reativos:

i) gerenciamento dos objetivos a fim de avaliar a sua compatibilidade com os objetivos.

ii) programa desenvolvido pela Lotus HAL, cujos critérios utilizados no processo de avaliação da eficácia das relações públicas envolvem:

a) número total de impactos ou menções à empresa, produto ou marca ao longo do tempo;

b) número total de impactos junto ao público-alvo;

c) número total de impactos sobre públicos-alvo específicos;

d) porcentagem de artigos positivos ao longo do tempo;

e) porcentagem de artigos negativos ao longo do tempo;

f) proporção de artigos positivos e negativos;

g) porcentagem de artigos positivos/negativos por assunto;

h) porcentagem de artigos positivos/negativos por publicação ou repórter;

i) porcentagem de artigos positivos/negativos por público-alvo;

iii) auditorias internas ou externas. As primeiras envolvem funcionários da empresa. As auditorias externas são conduzidas por consultores junto a clientes, quando estes contratam uma auditoria de Relações Públicas ou outra instituição externa à organização;

iv) Pesquisa de opinião pública sobre a empresa, seus produtos ou outro assunto que indique se os objetivos estão sendo atingidos. 
Um dos primeiros artigos sobre a avaliação de resultados de ações de RP foi publicado por Freitag (1998), que considerou que as possíveis formas de avaliação dessas ações são distribuídas num continuum, que vai de uma avaliação centrada nas saídas, ou número de resultados de $\mathrm{PR}$, até o outro extremo, em que os resultados são avaliados à luz de metas predefinidas. A proposta de Freitag está apresentada no Quadro 5.

Quadro 5 - Avaliação de ações de RP

\begin{tabular}{|c|l|l|l|l|l|l|}
\hline Produção & \multicolumn{1}{|c|}{$\begin{array}{l}\text { Distri- } \\
\text { buição }\end{array}$} & Cobertura & $\begin{array}{l}\text { Impres- } \\
\text { sões }\end{array}$ & $\begin{array}{l}\text { Valor da } \\
\text { Propa- } \\
\text { ganda }\end{array}$ & $\begin{array}{c}\text { Análise } \\
\text { do } \\
\text { conteúdo }\end{array}$ & Objetivo \\
\hline $\begin{array}{c}\text { Número } \\
\text { de } \\
\text { produtos } \\
\text { de PR }\end{array}$ & $\begin{array}{l}\text { Número } \\
\text { de mídias } \\
\text { que rece- } \\
\text { beram os } \\
\text { produtos } \\
\text { de PR }\end{array}$ & $\begin{array}{l}\text { Colunas, } \\
\text { centímetros, } \\
\text { segundos ou } \\
\text { minutos da } \\
\text { empresa ou } \\
\text { produto no } \\
\text { ar }\end{array}$ & $\begin{array}{l}\text { Publica- } \\
\text { ções na } \\
\text { mídia X } \\
\text { circula- } \\
\text { ção ou } \\
\text { alcance }\end{array}$ & $\begin{array}{l}\text { Custo de } \\
\text { propa- } \\
\text { ganda } \\
\text { que equi- } \\
\text { vale às } \\
\text { saídas de } \\
\text { PR }\end{array}$ & $\begin{array}{l}\text { Incli- } \\
\text { nações } \\
\text { positivas e } \\
\text { negativas, } \\
\text { mensagens } \\
\text {-chave }\end{array}$ & $\begin{array}{l}\text { Avaliação } \\
\text { do alcance } \\
\text { dos objeti- } \\
\text { vos por } \\
\text { meio de } \\
\text { pesquisa }\end{array}$ \\
\hline Saída $\leftarrow$
\end{tabular}

FONTE: FREITAG; 1998; p. 43.

Em relação às avaliações com foco nos objetivos, Freitag (1998, p. 44-45) ressalta que os resultados destas avaliações devem ser considerados nas definições das futuras ações de PR.

Belch e Belch (2008, p. 570) apontam que para a avaliação das ações de propaganda corporativa ou institucional, extensão de relações públicas, são adotadas as seguintes métricas:

i) pesquisas de atitudes em relação aos anunciantes corporativos;

ii) estudos que relacionam elementos da propaganda corporativa, tais como posição da nota numa revista, ou efeitos da fonte adotadas, com os preços de ações das empresas e; iii) Focus Group junto a público relevantes para avaliar reação às ações de propaganda corporativa. 
Lindenmann (1993) propôs um critério para mensurar os resultados de Relações Públicas, incluindo Publicidade, o Ketchum Effectiveness Yardstick (KEY). Segundo este critério, há três estágios de mensuração descritos na Figura 13.

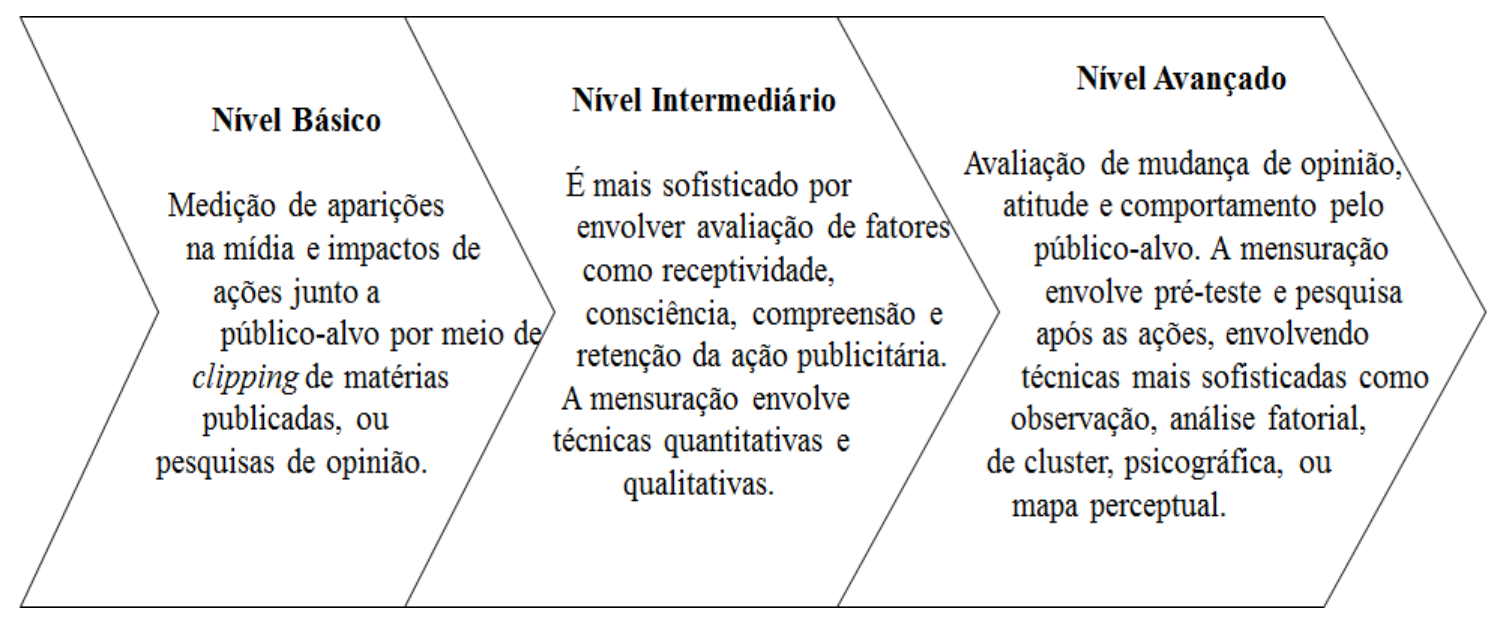

\section{Figura 13 - Ketchum Effectiveness Yardstick (KEY) FONTE: Adaptado de LINDENMANN; 1993.}

O nível básico envolve somente a contagem de aparições na mídia, é bastante comum, mas não se preocupa com o entendimento, retenção e impacto do conteúdo das aparições na mídia sobre o público-alvo.

O nível intermediário do KEY considera a percepção do público-alvo em relação aos resultados de publicidade positiva e negativa.

No nível avançado, são realizadas pesquisas de avaliação do impacto gerado pelos resultados gerados por esforços de RP.

Grunig e Grunig (1998, p. 144) ressaltam que as ações de RP devem ser desenvolvidas com uma orientação estratégica que desenvolva com os públicos-alvo, relacionamentos estáveis, abertos e baseados em confiança. Portanto, a qualidade dos relacionamentos com estes públicos deveria ser um indicador de longo prazo da efetividade de RP. 


\section{Métricas de publicidade}

A Publicidade é a geração de notícias sobre uma empresa, pessoa, produto ou serviço em diferentes mídias, sendo considerado um subconjunto dos esforços de Relações Públicas. É constituída por comunicações impessoais que não são diretamente pagas ou veiculadas por patrocinador identificado.

Não foram encontradas métricas específicas de publicidade. As mesmas métricas de RP são adotadas para avaliar resultados de Publicidade.

\section{Métricas de patrocínio}

Segundo Jensen e Hsu (2011, p. 352) não há uma métrica aceita universalmente como o GRP que mede exposição de propagandas. No entanto, as empresas vêm esforçando-se para avaliar os resultados dos patrocínios. (MEENAGHAN, 1999).

Algumas empresas recorrem a métricas como aumento de vendas e participação de mercado (STOTLAR, 1998; MEENAGHAN, 1998; SMOLIANOV; SHILBURY, 2005) e algumas recorrem aos preços de suas ações (FARRELL; FRAME, 1997; MIYAZAKI; MORGAN, 2001; OZTURK et al, 2004; CORNWELL et al, 2005). Outra forma de avaliar os resultados dos patrocínios é relacionar o patrocínio ao alcance de resultados específicos de negócios (SMOLIANOV; SHILBURY, 2005).

Há ainda as empresas que avaliam o impacto dos patrocínios por meio de redução da participação de mercado da concorrência (HANSEN; SCOTWIN, 1995; IRWIN; SUTTON, 1994).

MARTENSEN et al (2007, p. 283-301) propuseram um modelo de mensuração da efetividade de patrocínio que avalia o impacto em termos de atitude em relação à marca e intenção de compra e é validado por entrevistas com participantes do evento patrocinado.

Cameron (2009, p. 134) aponta que um dos problemas a com a medição de patrocínios é o fato de, a despeito das diferenças, durante algum tempo terem sido adotadas medidas 
de avaliação de resultados de propaganda para avaliar os resultados de ações de patrocínio. No entanto, ao contrário da propaganda, em que há somente a presença da empresa anunciante e do cliente, o patrocínio conta com três partes: o patrocinador, os clientes e o evento patrocinado. Cameron $(2009$, p. 134) propõe que a avaliação de resultados de patrocínios deve levar em conta o envolvimento do consumidor com a terceira parte do patrocínio, o evento patrocinado.

Uma ferramenta de avaliação de resultados é proposta pela consultoria SponsorMap, cuja metodologia é apresentada na Figura 14.

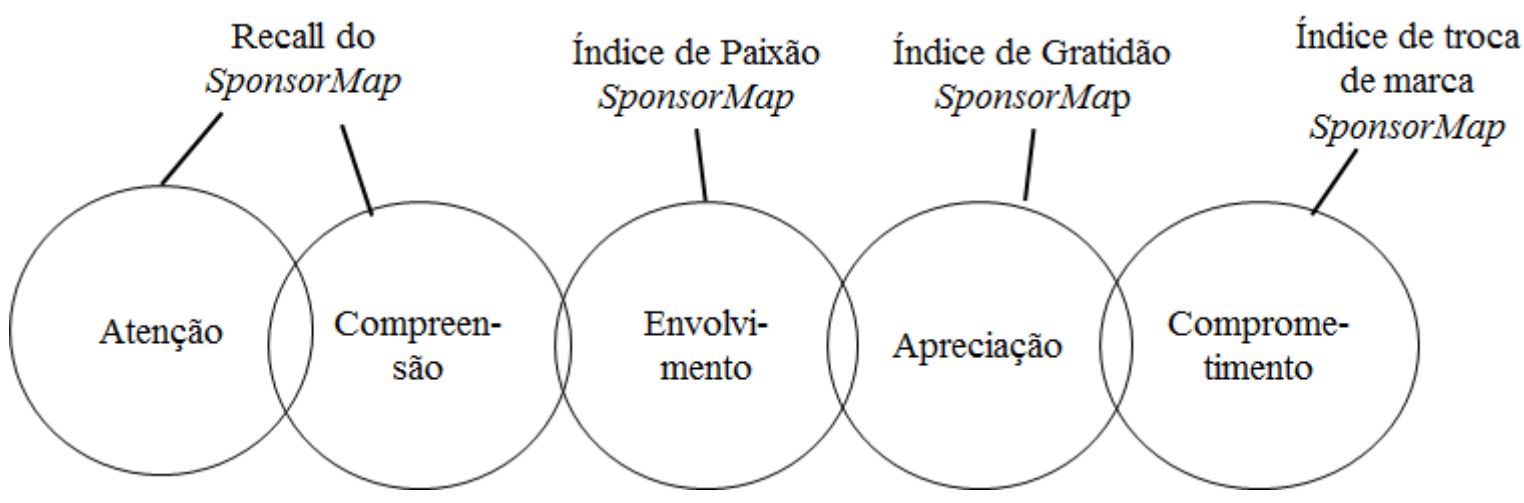

Figura 14 - O mapa de patrocínio FONTE: SPONSORMAP; 2011.

SponsorMap é uma ferramenta de pesquisa de medição de resultados de patrocínio que baseia-se em informações fornecidas pelo consumidor e na teoria do patrocínio, em oposição a métodos que consideram exclusivamente contagem de logos ou conscientização da marca do patrocinador. A ferramenta considera o rastreamento de patrocínio, eventos, patrocínios, difusão de patrocínio de pré-teste de medição e de medição da hospitalidade corporativa. A ferramenta mede cinco ingredientes essenciais em qualquer patrocínio:

i) atenção: ponto inicial de qualquer patrocínio que permite identificar se o público está apreciando a causa ou evento;

ii) compreensão: níveis ao longo dos quais a audiência é capaz de lembrar o patrocinador do evento;

iii) envolvimento emocional: a paixão da audiência pelo evento e seu patrocinador;

iv) apreciação: a gratidão ou apreço do público pelo evento e por seu patrocinador; 
v) comprometimento: mudança de atitude ou comportamento favorável em relação ao evento e/ou patrocinador.

Para avaliar os resultados dos patrocínios, as empresas estimam o valor do tempo de exposição da marca na cobertura de um evento. No entanto, essa maneira é questionável, pois “(...) ao colocar no mesmo plano a cobertura de mídia e a exposição da propaganda, não se leva em consideração o conteúdo de cada comunicação recebida pelo consumidor.” (KOTLER; KELLER, 2006, p. 593).

Outra proposta é apresentada por Cameron (2009, p. 133), que indica que se deve levar em conta que o engajamento emocional dos clientes com o evento dependerá de seu conteúdo. Portanto uma forma de avaliar os resultados de um patrocínio é medir o envolvimento do público com o tema do patrocínio, seja ele basebol, ou um time de futebol.

\section{Métricas de promoção de vendas}

Promoção de vendas caracteriza-se por envolver atividades de incentivos à força de vendas, distribuidores, ou consumidor final com orientação para o curto prazo.

Este fator do mix de comunicação vem recebendo cada vez mais destaque devido ao aumento do poder de barganha do varejo frente à indústria, que vem reagindo à pressão das negociações por meio de diferentes serviços, dentre os quais promoções que intensifiquem as vendas de seus produtos no varejo. Para Coughlan et al (2002), promoções eficientes no varejo têm as seguintes características:

i) movimentam o produto;

ii) promovem movimento na loja;

iii) fornecem valor agregado para o consumidor final.

Apesar de promoções ao consumidor incentivarem a responder mais rápido (BLATTBERG; NESLIN, 1990 apud SRINIVASAN et al, 2010), VAN HEERDE et al (2004) alertam que mudanças frequentes de preços podem minimizar o senso de 
urgência que as promoções menos regulares provocam e, ao invés de comprar a oferta, o consumidor pode perder o interesse.

Para Baker (2005, p. 318), medir o dispêndio em promoção é quase impossível, devido à sua natureza fragmentada. Por outro lado, as características de algumas promoções, como cupons, amostragem, prêmios de incentivos e concursos permitem uma mensuração mais precisa dos resultados.

Algumas métricas adotadas para avaliação dos resultados de ações de promoção (FARRIS et al, 2007, p. 257-258) são:

i) vendas básicas para determinar até que ponto as vendas são influenciadas por esforços específicos de marketing;

ii) vendas incrementais ou impulso promocional, que corresponde às vendas totais menos as vendas básicas. Neste caso, devem-se acompanhar as ações da concorrência e outros movimentos que possam influenciar o resultado das vendas;

iii) porcentagem de tempo em promoção, obtida a partir da porcentagem de tempo durante o qual promoções temporárias são oferecidas;

iv) taxa de resgate de cupons obtida pela divisão dos cupons resgatados divididos pelos cupons distribuídos;

v) custos para cupons e descontos que são o valor nominal dos cupons ou descontos mais taxas de resgate multiplicado pelo número de cupons resgatados ou descontos obtidos;

vi) porcentagem de vendas com cupons ou descontos, obtida pela divisão das vendas por cupons ou descontos pelo total de vendas.

Em se tratando de promoções relativas à concessão de descontos, Farris et al (2007, p. 258) indicam: 
vii) repasse de descontos que corresponde aos descontos promocionais oferecidos pelo comércio aos consumidores, divididos por descontos oferecidos pelos fabricantes para o varejo. Esta métrica indica até que ponto as promoções do fabricante influenciam as atividades promocionais ao longo do canal;

viii) desconto médio, obtido a partir do preço médio real por unidade dividido pelo preço de lista de cada unidade, o que indica o preço realmente pago por um produto e como este foi afetado ao longo do canal;

Devido ao fato dos bancos oferecerem serviços, esta ação de comunicação aplicada amplamente aos bens de consumo não deve ser aplicada a este tipo de negócio.

\section{Métricas de marketing direto}

Conforme mencionado no tópico descritivo do marketing direto, a mensurabilidade é uma das características implícitas a esta ação de comunicação de marketing.

Segundo Miller e Washington (2011, p. 352), a aquisição e a retenção de clientes são métricas de efetividade das ações de marketing direto.

Rosenwald (2005, p. 19-21) aponta métricas adicionais para a avaliação de ações de marketing direto pelas empresas:

i) Custo Permissível por Pedido (CPPP), que corresponde à diferença entre a receita que a empresa espera receber para cada unidade vendida do produto multiplicada pelo número de unidades previstas menos todos os custos de produção e distribuição do produto. $\mathrm{Ou}$ seja: $\mathrm{CPPP}=($ Receita Total $)-($ Todas as despesas incluindo lucro e ou margem de contribuição). Caso as iniciativas promocionais sejam bem-sucedidas e excedam o originalmente previsto, a organização beneficiou-se dessas despesas. A utilização adequada de bancos de dados para ações de marketing direto permite às empresas se beneficiarem de um maior retorno dos clientes aos quais são direcionadas promoções de upselling ou cross-selling. 
ii) Lifetime Value do Cliente (LTV) ou CLV, segundo Shimp (2002), Rosenwald (2005) e Baker (2005), o LTV depende de informações complicadas de serem obtidas ou previstas, tais como quanto o cliente comprará da empresa, ao longo de qual período e proporcionando qual margem. Apesar de complexo, este cálculo permite às empresas estimarem quanto podem ter de retorno para diferentes ações promocionais e é adequado para orientar a estratégia de relacionamento;

iii) Custo por pedido (CPP), que corresponde a quanto à empresa gastou ou planeja gastar em promoção dividido pelo número de vendas ou clientes que conseguiu ou espera conseguir. O entendimento de como operam é essencial para as empresas identificarem quais promoções devem ser direcionadas a sua base de cliente. (Rosenwald, 2005, p.33-35). Baker (2005, p.412) desmembra CPP em Custo por Resposta (CPR) e Custo por Venda (CPV).

Para que o CPPP e o CPP sejam utilizados adequadamente, é necessário que as empresas segmentem seus bancos de dados de clientes potenciais a fim de levantar corretamente esses custos e decidir quais ações promocionais são mais adequadas a cada segmento. Além de utilizá-los antes das ações promocionais, as empresas devem registrar e avaliar os resultados posteriores para atualizar informações sobre clientes e aprimorar projeções futuras.

O Gráfico 4 ilustra um exemplo de utilização dessas métricas para a escolha de quais clientes devem ser alvo de uma revalidação de cartões de crédito. Na situação hipotética, uma empresa usou todos os antigos clientes desde o lançamento do cartão numa campanha de revalidação de cartão de crédito. Estes clientes foram organizados em 16 listas classificadas com as letras A até a letra P.

A linha indica o limite de CPPP, que foi estabelecido em \$265 para cada cartão validado e a linha tracejada aos CPP de cada lista. Dentre as 16 listas utilizadas no exemplo, oito tiveram CPPs inferior ( $\mathrm{A}$ a $\mathrm{H}$ ), uma dentro do previsto e sete tiveram um CPP superior ao CPPP. O custo médio dos portadores de cartões revalidados acima do CPPP era $\$ 510$, quase o dobro de $\$ 265$. 
Caso a empresa não tivesse incluído na campanha as listas $\mathrm{K}$ a P, com CPP superior ao CPPP, teria perdido um percentual de revalidações de portadores de cartões (35\%), mas teria economizado mais da metade de suas despesas de marketing.

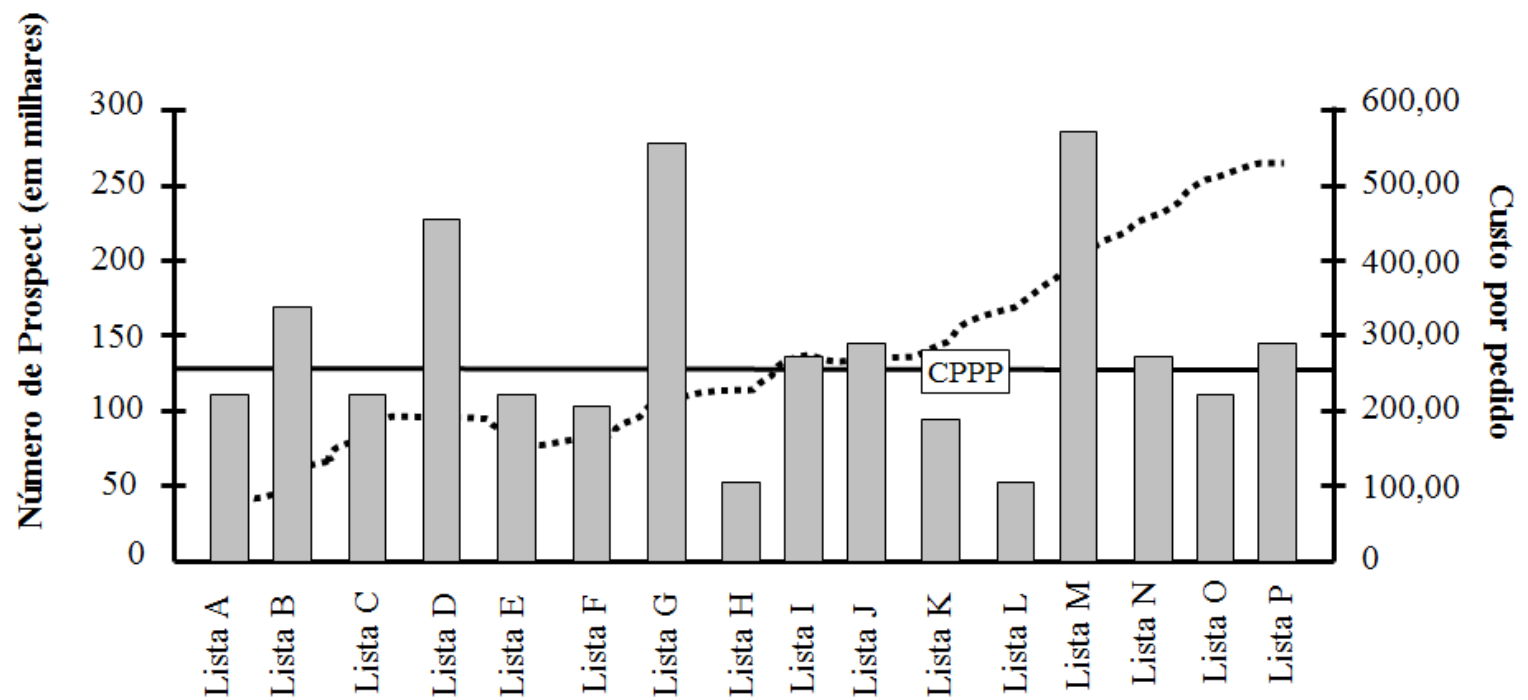

Pedidos Valor do CPP

$\mathrm{CPPP}=\$ 265$

\section{Gráfico 4 - Exemplo revalidação de cartões de crédito}

FONTE: ROSENWALD; 2005, p. 36.

Um dos aprendizados do exemplo ilustrado no Gráfico 4 é que as empresas não deveriam investir em todos os seus clientes, mas segmentá-los a fim de identificar quais justificam maiores investimentos. Este tipo de avaliação permite às empresas elegerem quais grupos de clientes devem ser contatados e quais não devem. Conforme mencionado por Rosenwald (2055, p. 35), "por mais difícil que seja a decisão a ser tomada, o que importa são os lucros obtidos com os clientes fiéis e não o número de clientes que a empresa possui".

Outra forma de avaliação dos resultados de ações de marketing direto de cartas é o cálculo do retorno de correspondências enviadas (SHIMP, 2002, p. 328).

Conforme pode ser observado na Tabela 3, pesquisa realizada em 2010 identificou as diferentes taxas de aquisição e retenção atingidas por diferentes mídias adotadas para ações de marketing direto. 
Tabela 3 - Efetividade de diferentes mídias de marketing direto nos EUA - 2010

\begin{tabular}{|l|c|c|}
\hline Mídia de Marketing Direto & Aquisição & Retenção \\
\hline Correio & $34 \%$ & $33 \%$ \\
\hline E-mail & $24 \%$ & $37 \%$ \\
\hline Telemarketing & $7 \%$ & $9 \%$ \\
\hline Catálogos & $6 \%$ & $7 \%$ \\
\hline Resposta ação na TV & $2 \%$ & $1 \%$ \\
\hline Resposta ação em Rádio & $1 \%$ & $1 \%$ \\
\hline Mobile Marketing & $1 \%$ & $1 \%$ \\
\hline
\end{tabular}

Fonte: MILLER; WASHINGTON, 2011, p. 352.

De acordo com as informações ilustradas na Tabela 3, o tradicional correio continua sendo a mídia com mais retorno para ações de marketing direto, tanto em aquisição de novos clientes quanto em retenção de antigos clientes. Em seguida vem o e-mail, com $24 \%$ e $37 \%$, de aquisição e retenção, respectivamente, bem à frente do telemarketing. Este resultado espelha a força que a internet vem assumindo na vida do consumidor contemporâneo.

Chama a atenção o fato de que, apesar da penetração dos celulares, ações de mobile marketing apresentem um resultado tão baixo. Não há informações disponíveis sobre estas ações, mas uma explicação pode ser a precariedade das imagens e da leitura de texto nesta mídia.

\section{Métricas de venda pessoal}

A avaliação dos resultados de vendas pessoais é conduzida pela própria área de vendas e adota critérios relacionados a vendas, tais como análise das contas-alvo, das atividades interfuncionais e da abertura de novas contas. Apesar dos custos elevados, o retorno de investimentos em venda pessoal pode ser considerável.

Belch e Belch (2008) e Farris et al (2007, p.172-174) indicam algumas métricas para avaliação do impacto da venda pessoal, dentre as quais: 
i) total de vendas vis-à-vis as metas estabelecidas para a equipe de vendas;

ii) previsão de potencial de vendas que compreende o número de clientes em potencial e seu poder de compra;

iii) remuneração da força de vendas que possibilita à empresa avaliar como os resultados estão em relação aos objetivos previamente estabelecidos. Este fator envolve salário básico, bônus e/ou comissão;

iv) carga de trabalho (horas) para atender clientes em potencial e clientes, que indica a produtividade da área e eventuais necessidades de ajustes;

v) eficácia da equipe de vendas com base em contatos com clientes potenciais, clientes ativos, poder do território e despesas e;

vi) funil de vendas, que corresponde ao número de clientes e clientes em potencial em negociação, ou seja em diferentes estágios do ciclo de vendas.

\section{Métricas de product placement}

Balasubramanian (1994, p. 38-39) apontou que uma das desvantagens do product placement é a inexistência de medidas seguras e precisas que indiquem seu real Custo vs. Benefício, como o CPM adotado para avaliação das mídias.

Para Williams et al (2011, p. 4), ainda é difícil medir os resultados de ações de product placement.

Cowley e Barron (2008, p. 89) e Bressoud et al (2010, p. 374) apontam que os efeitos do product placement na memória e atitude do consumidor estão consagrados. Por isso, as avaliações mais comuns desta ação de comunicação são relacionadas a testes de lembrança ou memória da ação de product placement - recall e reconhecimento do produto ou marca e testes de atitude frente à marca (RUSSELL, 2002; COWLEY e BARRON, 2008; BRESSOUD et al, 2010). 
Segundo Belch e Belch (2008, p. 438), não há um padrão de uso de mensuração dos resultados de ações de product placement. Alguns exemplos de ferramentas de mensuração mencionados pelos autores são:

i) Nielsen Media Research para levantamento de audiências de TV;

ii) IAG Research, que dispõe de um painel com cerca de cinco mil espectadores, examina os product placement observados em programas de TV;

iii) Brand Advisor que avalia a integração de marca em filmes.

\section{Métricas de merchandising}

Segundo o POPAI Brasil, uma vez que as ações de merchandising têm como principal objetivo gerar venda, a apuração das vendas antes e depois da ação é uma forma de avaliação de resultados.

Para Quelch e Cannon-Bonventre (1983, p. 164), a avaliação de ações de merchandising é fácil devido ao registro das vendas nos estabelecimentos comerciais no momento do pagamento da mercadoria. Os autores ressaltam que a avaliação das ações de merchandising deve considerar uma comparação com ações alternativas a fim de avaliar se os resultados atingidos foram de fato favoráveis. Outra recomendação é que sejam feitas visitas ao campo para observação do impacto visual de ações que envolvam colocação de displays ou outras peças promocionais no ponto de venda (QUELCH; CANNON-BONVENTRE, 1983, p. 168-169).

As ações do merchandising visam também aumentar a rotatividade dos estoques, devendo ser adotada ferramenta que permita avalia o giro do estoque a fim de avaliar os resultados por estas ações. Outra forma de avaliação que pode ser adotada é pesquisa de avaliação dos resultados atingidos por ações de experimentação (POPAI, 2011).

\section{Métricas de marketing digital}

Os avanços tecnológicos no atual cenário têm aumentado o poder do consumidor digital e imposto desafios para a medição dos resultados de programas de IMC (EWING, 2009, p. 105). 
Kliatchko (2009, p.12) aponta que, devido ao fato do mercado digital fornecer uma quantidade considerável de conteúdo gratuito, torna-se difícil monetizar determinados serviços e medir alguns resultados. No entanto, como as campanhas de comunicação de marketing cada vez utilizam mais a internet em seus programas globais, a medição e análise desses programas deve ser aprimorada com o auxílio de ferramentas disponíveis, tais como web analytics que permite rastrear o comportamento dos públicos-alvo nos sites e fora deles. Para Kliatchko (2009, p.12), o esforço para chegar a melhores práticas para medição de IMC envolve, portanto, desenvolver métricas que combinem o desempenho financeiro da empresa com a avaliação dos resultados atingidos.

Devido à tecnologia, à disponibilidade de dados sobre campanhas on-line e à interação entre internautas e os sites, as métricas relativas a esta mídia são mais fáceis de obter, inclusive em relação a clientes individuais. Algumas métricas indicadas por Farris et al (2007, p. 305-318) visando avaliar o tráfego e a atividade em um site são:

i) exposições ou ODV, que representam o número de oportunidades que foram apresentadas à audiência da campanha. No entanto, pela quantidade de informação através de imagens e textos contidos numa página, nem todas as exposições são de fato absorvidas pelos visitantes;

ii) impactos, que correspondem à contagem de números de arquivos fornecidos aos visitantes do site. Resulta do número de impactos em um site multiplicado pelo número de arquivos de cada página visitada. Esta métrica é bastante importante para cálculo de capacidade do servidor.

As métricas de exposição e impacto apontam oportunidades, mas não levam em conta o número de anúncios realmente vistos, nem a percepção de qualidade de seu conteúdo pelos visitantes. Com o objetivo de captar a resposta dos clientes às ações em sites utilizam-se as seguintes métricas:

iii) taxa de cliques do mouse levam os visitantes de uma página da web ou site para outro site por meio dos hiperlinks, nos quais se incluem banners, que conduzem o internauta a uma ação de compra. Essa taxa mede a proporção de visitantes que deram início a uma ação a respeito de um anúncio que os tenha direcionado à outra página e 
equivale ao número de vezes que um clique é feito sobre um comercial, dividido pelo total de exposições, que no caso da internet, corresponde ao número de vezes que um anúncio é exibido.

Farris et al (2007, p. 308) exaltam que, a não ser que o clique esteja associado à compra imediata, esta métrica não é suficiente para suportar uma decisão marketing. A fim de compreender o comportamento do usuário na internet, Farris el at (2007, p. 315-317), indicam as seguintes métricas:

iv) visitantes ou visitantes únicos equivalem ao número de indivíduos que requisitam páginas do servidos da empresa num determinado período. Procura-se garantir que a contagem de cada visitante ocorra apenas uma vez.

v) visitas, visualizações individuais ou sessões às páginas indicam o número de vezes que os indivíduos requisitam uma página, ou quantas vezes uma página foi exibida aos usuários e é calculado dividindo-se o número de impactos pelo número de arquivos na página.

Os cookies são um recurso essencial para as empresas rastrearem o fluxo dos visitantes em seus sites, identificarem se um visitante está retornando ou se é um novo usuário e, desta forma evitar uma dupla contagem. Além de medir o número de visitantes e visitas, os cookies permitem às empresas adotarem com segurança as seguintes métricas:

vi) fluxo de cliques, que permite identificar o caminho percorrido por um usuário na internet e norteia as empresas a aprimorarem alguns fluxos, destacarem ou venderem anúncios em algumas páginas;

vii) taxa de abandono de compras permite às empresas conhecer o percentual de compras que são suspensas pelos visitantes;

viii) custo por exposição, custos para oferecer aos potenciais clientes uma oportunidade de ver um anúncio; 
ix) custo por clique, quantia gasta para que se clique em um anúncio. É indicado para casos de anúncios cujo objetivo seja o de gerar um clique;

x) custo por pedido equivale ao custo para obtenção de um pedido. Também é indicado para avaliar um anúncio cujo objetivo seja gerar um pedido. Esta métrica é afetada por devoluções e situações em que haja múltiplos canais;

xi) custo por cliente adquirido é semelhante ao custo por pedido, mas refere-se especificamente aos novos clientes.

A Figura 15 ilustra o mapeamento do fluxo de visitas de um visitante a um site de livros e como algumas métricas de marketing digital são aplicadas a esta situação. O exemplo ilustrado refere-se a um usuário específico, os sites possuem ferramentas que permitem calcular o desempenho do total de visitantes. O custo por exposição, clique e pedido considerará o conjunto de visitantes ao longo de um período.

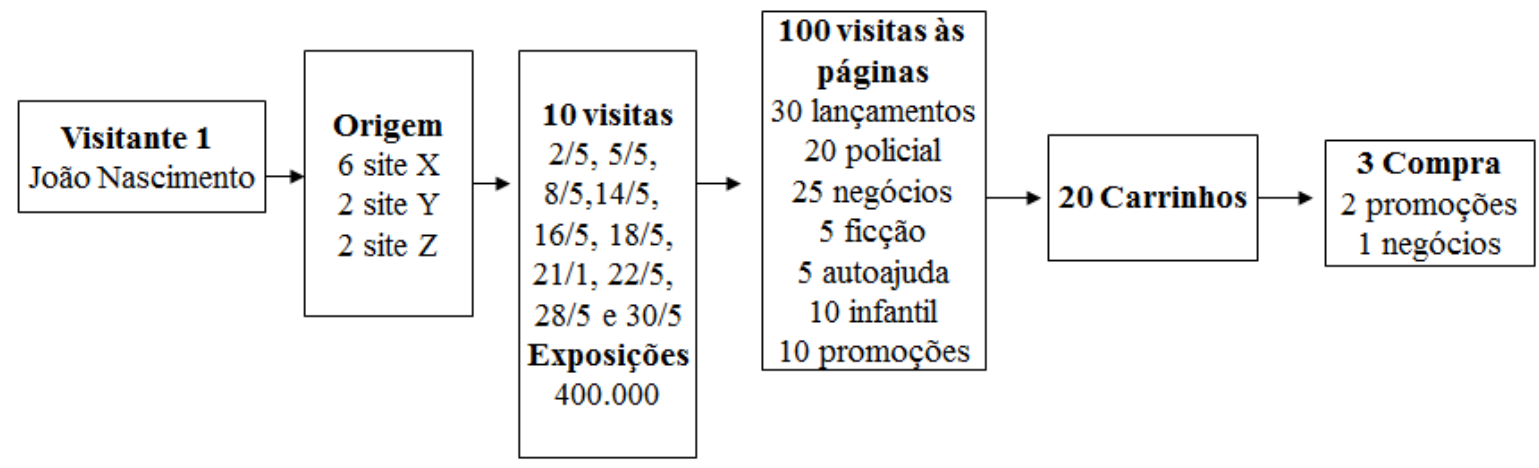

Taxa de cliques: $100 / 12.000=0,0083$

Taxa de abandono visitante $1: 17 / 20=0,85$

\section{Figura 15 - Fluxo de visitas de um visitante identificado}

FONTE: Elaborado pela autora

Farris et al (2007) indicam métricas adicionais relacionadas à avaliação da eficácia da propaganda no ambiente da internet em função de sua frequência:

i) função de resposta à frequência linear refere-se a todas as exposições da propaganda com igual impacto e pressupõe que as pessoas reajam igualmente a toda exposição a um comercial, não importando quantas outras exposições ocorreram no passado. Ou seja, 
não considera que haja uma saturação. Por este motivo, os autores consideram que esta função não seja realista;

ii) função de resposta à frequência da curva de aprendizado parte da premissa de que um comercial não é absorvido nas primeiras exibições pelo público-alvo. À medida que ocorre a repetição, a mensagem é absorvida e num último estágio o público perde o interesse ou não é mais influenciado pela campanha. A curva de aprendizado terá sua forma determinada por um conjunto de fatores como a escolha da mídia, público-alvo e frequência de exposições;

iii) funções de resposta de frequência limiar indicam o número de exposições necessário para que a mensagem de uma campanha seja absorvida e pressupõe que um comercial não tem nenhum efeito até que sua exposição atinja certo nível.

O Gráfico 5 sintetiza as características de cada uma das três funções de resposta de frequência numa situação hipotética. Conforme este gráfico, o máximo de eficácia possível ocorre quando a resposta ao comercial atinge $100 \%$.

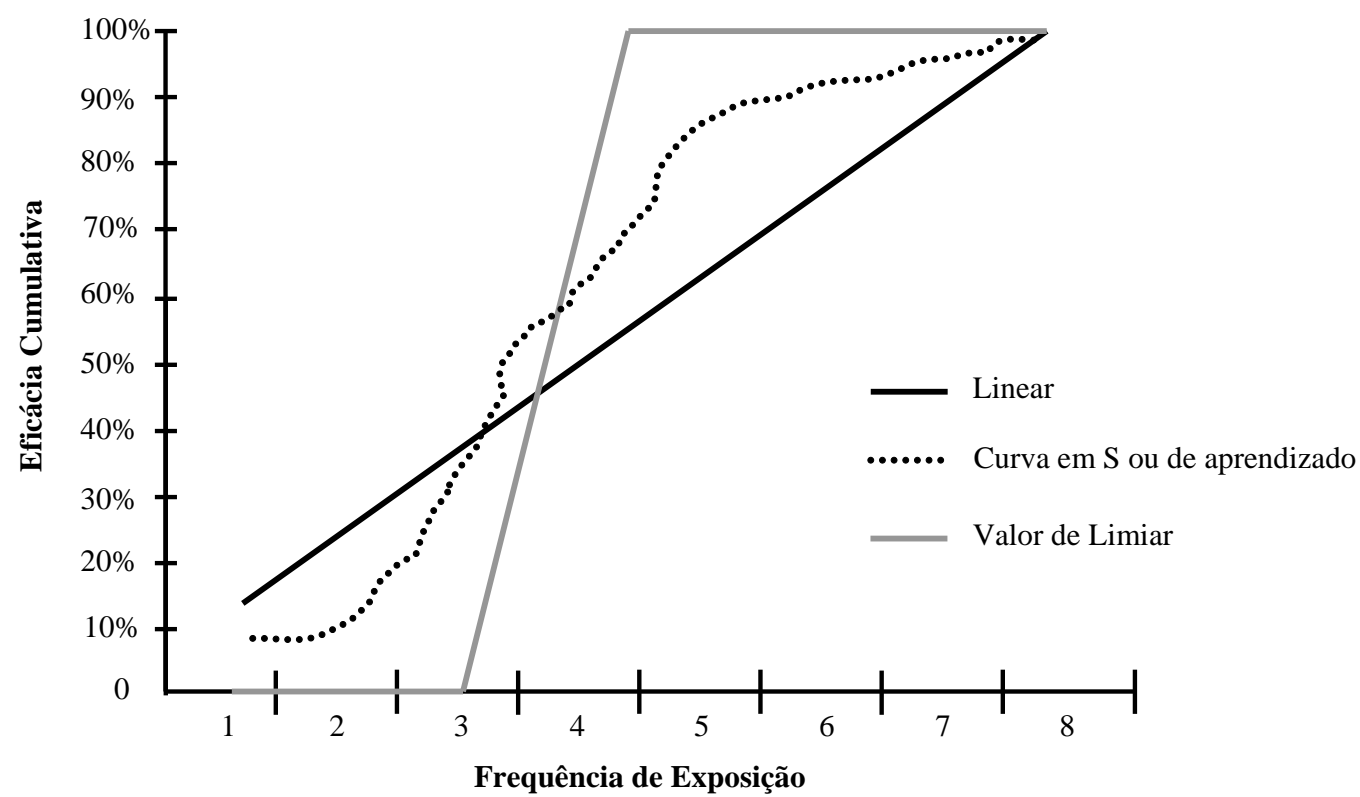

Gráfico 5 - Eficácia cumulativa de comerciais FONTE: FARRIS et al;2007, p.300.

No modelo de resposta linear, "cada exposição abaixo do ponto de saturação gera um oitavo, ou 12,5\% do efeito total (...) " (FARRIS et al, 2007, p. 298). 
Os efeitos cumulativos do modelo de curva de aprendizado traçam uma curva cuja forma “(...) depende das circunstâncias de uma determinada campanha, incluindo a seleção dos meios para o comercial, o público-alvo e a frequência de exposições" (FARRIS et al, 2007, p. 299).

A função da curva limiar é "uma função da resposta de limiar, ou se a frequência for maior ou igual ao nível de limiar da eficácia, então, a campanha será $100 \%$ eficaz. Se a frequência é menor do que o limiar, não haverá efeito." (FARRIS et al, 2007, p. 299). Pela ótica deste modelo, no Gráfico 5, não ocorre nenhum efeito até a quarta posição, momento em que $100 \%$ do benefício do comercial é percebido.

Farris et al (2007, p. 301-303) indicam outras métricas para avaliação de propagandas:

iv) frequência efetiva, ou o número de vezes que um indivíduo deve ver um comercial a fim de registrar sua mensagem dentro de um período específico;

v) alcance efetivo, que corresponde ao número de pessoas ou percentual do público exposto a uma campanha com frequência maior ou igual à frequência efetiva, ou seja, "a população que recebe o 'mínimo' de exposição efetiva de um comercial ou campanha" FARRIS et al (2007, p. 303);

vi) percentual de presença, que quantifica a presença do comercial de uma marca em relação à totalidade de comerciais em um mercado específico. Ele é medido dividindose o comercial da marca ou produto pelo total de comerciais.

\section{Google e YouTube}

O Google possui ferramentas que permitem mapear o fluxo e o perfil de seu visitante com grande precisão e cobra de seus clientes anunciantes valores compatíveis com os resultados atingidos. Discute-se a ética da utilização de cookies, por serem uma invasão à privacidade dos usuários da Internet, cujos passos podem ser acompanhados e registrados. 
Para Zigmond e Stipp (2010, p, 163) e Forootan (2008, p. 22) o Google está revolucionando a forma como os anunciantes avaliam os resultados de seus investimentos em comunicação e direcionam seus investimentos na internet.

O Google Analytics tornou-se uma das mais poderosas ferramentas de marketing na internet, ajudando e mudando a gestão de comunicação pelos anunciantes, editores e proprietários de websites. Esta ferramenta é uma solução de análise da web de cunho empresarial que fornece a visibilidade do tráfego e da eficiência do marketing do website de seus clientes. Esta ferramenta é baseada num robusto software estatístico gratuito que por meio de recursos avançados, flexíveis e de fácil utilização permitem que seus usuários analisem dados de tráfego em seus sites e uma gestão mais precisa para as decisões de anúncios por segmento (GOOGLE ANALYTICS, 2011).

O Google Analytics indica a proveniência dos visitantes por cidade, estado ou país, se foram referidos por ferramentas de motores de busca, anúncios, e-mails ou blogs permitindo uma análise precisa por segmento de mercado. Como consequência destas possibilidades, a ferramenta permite um controle mais eficaz da relação custo vs. benefício das campanhas tendo em vista as diferentes possibilidades de ações na internet.

Qualquer campanha de e-mail é facilmente codificada e monitorada pela ferramenta que é capaz de gerar relatórios de tráfego, identificar os links de maior impacto, os picos de visitas, o tempo de permanência e os novos destinos tomados pelos usuários. Desta forma, é possível realizar ajustes rápidos em campanhas.

Além da gestão das campanhas online, Forootan (2008, p. 22) aponta que o Google Analytics possibilita um aprimoramento do e-commerce e estreita o relacionamento com os clientes, aumentando a taxa de conversão de novos clientes e de recuperação de clientes inativos.

Outra ferramenta que auxilia a avaliação dos resultados de ações de comunicação na internet é o Google Trends que permite a comparação de buscas a diferentes termos ao longo de um período. A ferramenta analisa uma parcela das pesquisas do Google web 
para calcular quantas pesquisas foram feitas para os termos que o usuário deseja avaliar relativamente ao número total de pesquisas feitas no Google ao longo do tempo.

O Google Trends detecta um pico no volume de notícias sobre um termo, como, fusão, aquisição, entrada de um novo concorrente e o destaca no gráfico. Em fins de 2011, este recurso estava disponível somente para manchetes de notícias em inglês.

O Gráfico 6 apresenta um exemplo de relatório emitido por esta ferramenta. O conteúdo refere-se à busca pelas três maiores bancos do Brasil, segundo relatório do Banco Central do Brasil (BACEN) de 2011.

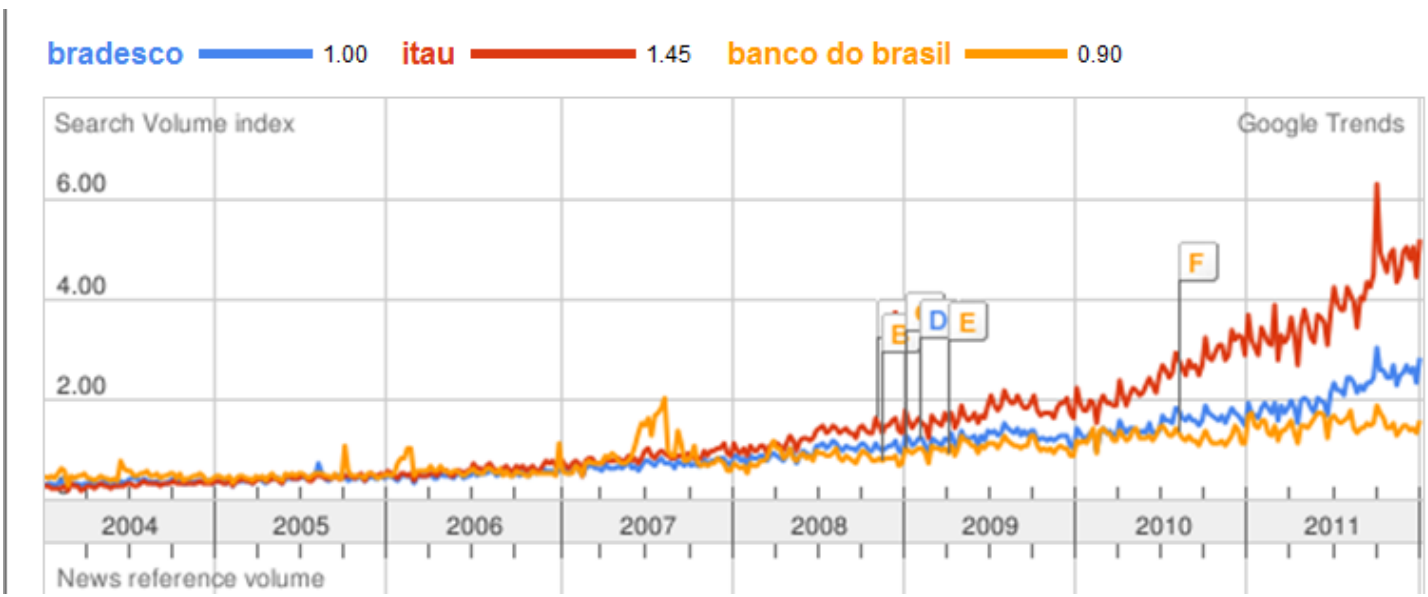

Gráfico 6 - Visitas aos sites das três maiores instituições financeiras 2004 - 2011

Fonte: GOOGLE TRENDS; 2011.

A análise do Gráfico 6 em conjunto com as ações que tenham sido tomadas neste período indica a evolução dos acessos ao longo de 2004-2011 e permite aos gestores de comunicação destas empresas associar o desempenho das buscas a estas ações.

Além dos gráficos de volume de pesquisa associados aos termos e notícias, a ferramenta do Google Trends mostra as principais regiões, cidades e línguas em que os internautas pesquisaram para o primeiro termo de busca que é pesquisado no site da Google Trends (GOOGLE TRENDS, 2011). A Figura 16 ilustra como são apresentadas informações quanto à origem dos internautas que buscam determinado termo. 


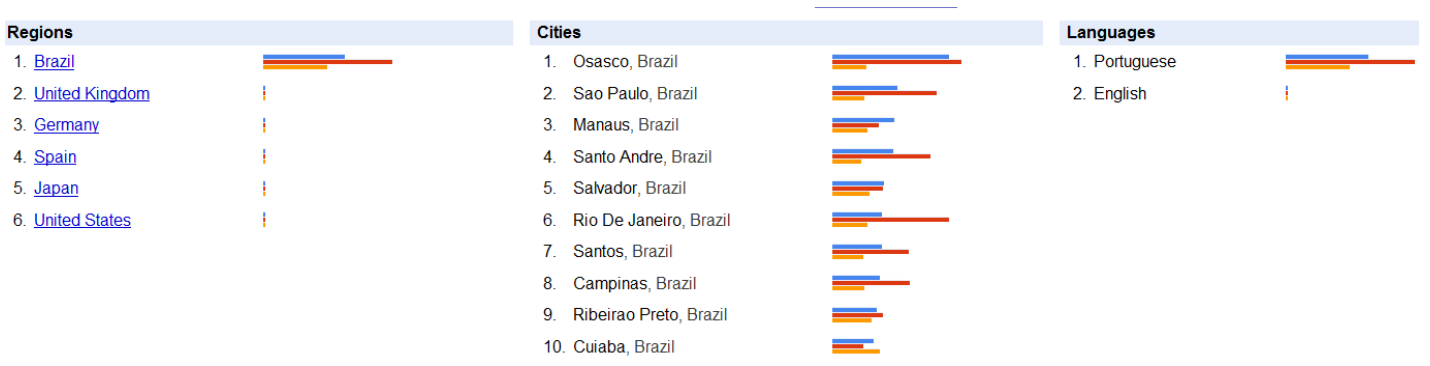

Figura 16 - Origem das visitas aos sites das três maiores instituições financeiras 2004-2011

FONTE: GOOGLE TRENDS; 2011.

A partir da Figura 16 é possível conhecer regiões e cidades das quais se originou a maioria das buscas às três instituições, o que permite associar os efeitos de ações de comunicação sobre o comportamento de busca. Vale ressaltar que para a análise é necessário considerar tanto as ações online quanto as offline.

O YouTube também apresenta facilidades para mensuração dos resultados de seus usuários. Ao entrar no resultado de uma busca, é possível saber o número de acessos ao vídeo postado no site, quantos internautas o avaliaram e, das avaliações, quantas foram favoráveis - gostaram - e quantas foram desfavoráveis - não gostaram.

Conforme ilustrado na Figura 17, além das informações padrão, em alguns casos, o site fornece estatísticas comportamentais, que incluem a primeira exibição do vídeo em celular, número de internautas que comentaram sobre o vídeo, quantos o incluíram como favorito, quantos o indicaram, quando foi incorporado a uma rede social e número de exibições nesta rede, as palavras-chave associadas ao vídeo, dentre outras informações. 
Total de exibições: 14172496
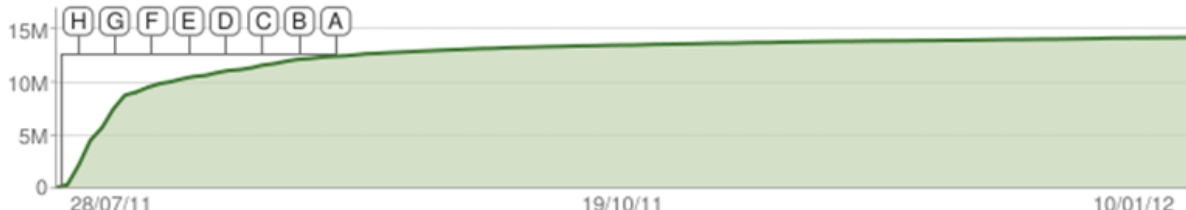

Avaliações: 53429

Gosta: 49737

Não gosta: 3692

Eventos de descoberta significativos

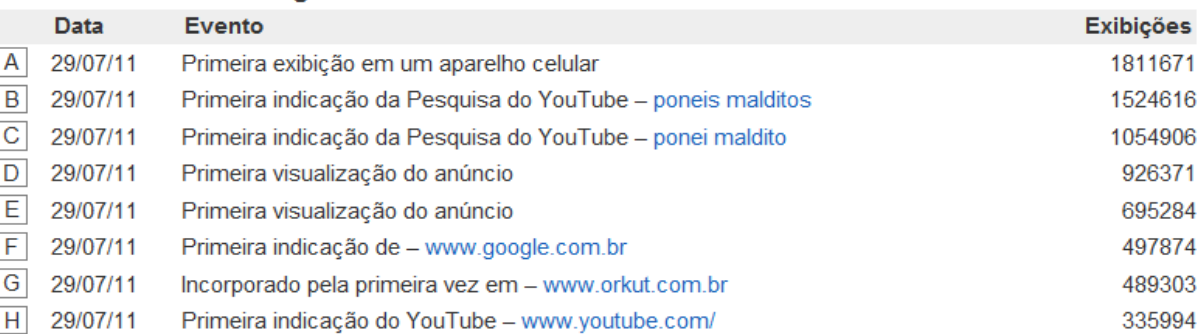

\section{Figura 17 - Estatísticas comportamentais disponíveis no YouTube} FONTE: YOUTUBE; 2011.

As estatísticas disponíveis no You Tube incluem quão popular o vídeo é em diferentes regiões do mundo e predileção pelo vídeo por faixa etária e sexo predominante nas diferentes faixas etárias, conforme ilustrado na Figura 18.

\section{Público}

Este video é mais popular com:

Sexo

Masculino

Masculino

Feminino

$18-24$

25-34

$13-17$

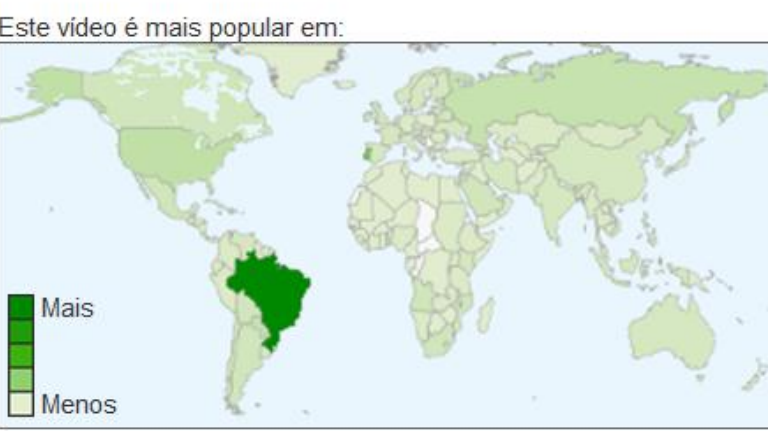

Figura 18 - Estatísticas demográficas disponíveis no YouTube FONTE: YOUTUBE; 2011.

A partir das informações contidas no relatório da Figura 18, é possível avaliar o vídeo postado mais popular, junto a segmentos de consumidores classificados segundo região, faixa etária e sexo. 


\section{Métricas de eventos técnicos}

Em consonância à escassez de literatura sobre eventos técnicos, foram encontrados poucos autores que tratassem da mensuração dos resultados deste tipo de ação de comunicação.

Para a avaliação dos resultados de eventos Phillips et al (2008) propõem algumas métricas para avaliação dos resultados de eventos em formato de conferência:

i) dados de entrada de público em conferências e eventos, incluindo número de sessões, participantes, público, custos e eficiência;

ii) reação e valor percebido, avaliam a reação e a satisfação com a experiência do evento, o ambiente, seu conteúdo e valor, em termos de relevância e importância do evento;

iii) aprendizado dos participantes em termos de informação, conhecimento, habilidades e contatos estabelecidos. Ou seja, os benefícios decorrentes do evento;

iv) aplicação e implementação do conteúdo do evento após sua realização, como serão utilizados a informação, o conhecimento, as habilidades e os contatos adquiridos.

\section{Métricas de marketing de relacionamento}

A métrica consagrada de marketing de relacionamento adequada para orientar a estratégia de relacionamento é LTV ou CLV. Esta métrica prescinde de informações complicadas de serem obtidas ou previstas, como quanto o cliente comprará da empresa, ao longo de qual período e a margem esperada (SHIMP, 2002, ROSENWALD, 2005; BAKER, 2005).

Uma das dimensões analisadas por Farris et al (2007) é a Rentabilidade do cliente. O Quadro 6 apresenta as métricas de rentabilidade identificadas por esses autores. 


\section{Quadro 6 - Métricas de rentabilidade do cliente}

\begin{tabular}{|l|l|l|}
\hline MÉTRICA & DEFINIÇÃO & OBJETIVO \\
\hline Clientes & $\begin{array}{l}\text { O número de clientes que } \\
\text { comprou da empresa durante um } \\
\text { período de tempo específico }\end{array}$ & $\begin{array}{l}\text { Mensurar como a empresa está } \\
\text { atraindo e retendo clientes }\end{array}$ \\
\hline Recência & $\begin{array}{l}\text { Período de tempo desde a última } \\
\text { compra do cliente }\end{array}$ & $\begin{array}{l}\text { Mapear mudanças no número de } \\
\text { clientes ativos }\end{array}$ \\
\hline $\begin{array}{l}\text { Taxa de } \\
\text { retenção }\end{array}$ & $\begin{array}{l}\text { A razão de clientes retidos para o } \\
\text { número de risco }\end{array}$ & $\begin{array}{l}\text { Mapear mudanças na habilidade } \\
\text { da empresa em reter clientes }\end{array}$ \\
\hline $\begin{array}{l}\text { Rentabilidade } \\
\text { do cliente }\end{array}$ & $\begin{array}{l}\text { Diferença entre as receitas obtidas } \\
\text { e os custos associados com a } \\
\text { relação com o cliente durante um } \\
\text { período específico }\end{array}$ & $\begin{array}{l}\text { Permitir à empresa identificar } \\
\text { quais clientes são rentáveis e } \\
\text { quais não são }\end{array}$ \\
\hline $\begin{array}{l}\text { Valor de } \\
\text { Duração do } \\
\text { Cliente (VDC) }\end{array}$ & $\begin{array}{l}\text { O valor atual de futuros fluxos de } \\
\text { caixa atribuídos à relação com o } \\
\text { cliente }\end{array}$ & $\begin{array}{l}\text { Gerenciar a relação com o } \\
\text { cliente a fim de melhorar o VDC } \\
\text { e estabelecer o orçamento de } \\
\text { aquisição de clientes }\end{array}$ \\
\hline $\begin{array}{l}\text { Previsão do } \\
\text { valor de } \\
\text { duração }\end{array}$ & $\begin{array}{l}\text { Taxa de resposta multiplicada } \\
\text { pela soma de margem inicial do } \\
\text { valor de duração do cliente } \\
\text { adquirido menos o custo do } \\
\text { trabalho de prospecção }\end{array}$ & $\begin{array}{l}\text { Guiar as decisões de prospecção } \\
\text { da empresa. A prospecção é } \\
\text { benéfica somente se o valor de } \\
\text { duração previsto e esperado for } \\
\text { positivo }\end{array}$ \\
\hline $\begin{array}{l}\text { Custo médio de } \\
\text { aquisição }\end{array}$ & $\begin{array}{l}\text { Razão da despesa de aquisição } \\
\text { para o número de novos clientes } \\
\text { adquiridos }\end{array}$ & $\begin{array}{l}\text { Mapear o custo da aquisição de } \\
\text { novos clientes e comparar esse } \\
\text { custo com o valor dos clientes } \\
\text { recém-adquiridos }\end{array}$ \\
$\begin{array}{l}\text { Razão da despesa de retenção para } \\
\text { o número de novos clientes } \\
\text { adquiridos. }\end{array}$ & $\begin{array}{l}\text { Monitorar as despesas de } \\
\text { retenção por cliente }\end{array}$ \\
\hline ando
\end{tabular}

FONTE: Adaptado de FARRIS et al; 2007, p. 146-147.

Os autores ressaltam que a avaliação da rentabilidade do cliente tem o intuito de gerar uma orientação para o cliente, e não para as unidades vendidas. Por meio desta abordagem, a empresa é capaz de identificar o desempenho financeiro passado das relações com os clientes e desenvolver ações específicas que preservem o relacionamento futuro e possibilitem sua rentabilidade (FARRIS et al, 2007, p. 145). 


\section{Métricas de Advertainment}

Segundo Belch e Belch (2008, p. 436), as empresas que adotam o advertainment, consideram a pesquisa de lembrança do evento como uma das formas de avaliação, quando é uma atividade no mundo real.

Tendo em vista o fato de esta ação ser um desdobramento de patrocínio, as métricas de patrocínio também são aplicáveis à avaliação dos resultados deste tipo de ação.

Em se tratando de uma ação de advertainment online, além de uma pesquisa de lembrança do vídeo, a avaliação de resultados envolverá as tradicionais métricas de marketing digital citadas por Farris et al (2007, p. 305-317) e apresentadas anteriormente:

i) exposições referem-se à ideia de ODV, ou número de oportunidades apresentadas às pessoas para verem um comercial, pois muitas exposições não são realmente percebidas pelos espectadores e por isso não mostram o efeito de um comercial sobre os clientes potenciais;

ii) impactos correspondem ao número de total de objetos e arquivos individuais que contém textos, imagens, áudios e vídeos requisitados em um determinado período. Como as páginas compostas de muitos arquivos pequenos geram numerosos impactos, deve-se ter cuidado para não impressionar-se excessivamente com grande número de impactos. (FARRIS et al, 2007, p. 305);

iii) exposições ou ODV, impactos, taxa de cliques, visitas às páginas (pageviews), visitantes ou visitantes únicos, fluxo de cliques, taxa de abandono de compras custo por exposição, custo por clique, custo por pedido, custo por cliente adquirido, (FARRIS et al, 2007);

iv) métricas de eficácia da propaganda: função de resposta à frequência linear, função de resposta à frequência da curva de aprendizado, funções de resposta de frequência 
limiar, resposta à frequência efetiva; alcance efetivo, percentual de presença (FARRIS et al, 2007);

v) relacionamento com os clientes, taxa de conversão e de recuperação de clientes inativos (FOROOTAN, 2008).

Aplicam-se também os relatórios emitidos pelo Google Analytics e YouTube.

vi) métricas específicas do Google Analytics e YouTube:

a) tráfego, links de maior impacto, picos de visitas, o tempo de permanência e novos destinos tomados pelos usuários (GOOGLE, 2011);

b) vídeos - número de acessos, quantos avaliaram e quantas avaliações favoráveis e desfavoráveis (YOUTUBE, 2011).

\section{Métricas de Marketing Viral, Buzz marketing e Redes Sociais}

Ao pesquisar sobre as métricas relativas ao buzz marketing, marketing viral e redes sociais, constatou-se que, tendo em vista o potencial de propagação de ideias e geração de um buzz ou de um viral, inerente às redes sociais, as métricas destas três ferramentas de comunicação online são comuns. Por este motivo, as métricas dessas três ações de comunicação são apresentadas conjuntamente.

Além disso, essas três ações de comunicação são inseridas no ambiente da internet, portanto as métricas apresentadas no tópico relativo ao marketing digital são válidas para a avaliação dos resultados das ações tratadas no presente tópico.

Devido ao fato de o marketing viral ser uma modalidade de comunicação moderna do boca a boca com o diferencial de utilização da internet para a propagação da mensagem (OGDEN; CRESCITELLI, 2007, p. 32), foram utilizados artigos relacionados à métrica de boca a boca negativo e positivo.

Phelps et al (2004, p. 346) sugerem que tendo em vista a rapidez de propagação de informações na internet, o acompanhamento do comportamento online seja contínuo e envolva os meios relevantes, ou seja redes sociais, blogs, fóruns e comunidades online. 
Segundo Khermouch e Green (2001), mesmo que uma empresa inicie um marketing viral, é difícil medir o alcance que esta ação gerará, devido à inexistência de ferramentas que permitam mensurar a propagação entre as pessoas que estão fora do controle da organização. Os autores recomendam como métrica a avaliação da publicidade gerada por campanhas de marketing viral. (KHERMOUCH e GREEN, 2001, p. 53).

Kumar et al (2007, p. 140) ressaltam que, muitas vezes, as boas intenções do boca a boca não passam de boas intenções. Os autores desenvolveram um estudo com quase 9,9 mil clientes de uma empresa de telecomunicações e 6,7 mil de serviços financeiros e acompanharam suas intenções de boca a boca e os efeitos de suas referências. Enquanto $68 \%$ dos clientes da empresa de serviços financeiros demonstraram intenção de referenciar a empresa, somente $33 \%$ de fato o fizeram. Na outra empresa, $81 \%$ dos clientes indicaram intenção, mas somente $30 \%$ consumaram. Ao analisar os efeitos sobre o comportamento dos que receberam suas recomendações, $14 \%$ e $12 \%$ das recomendações de fato geraram novos clientes, respectivamente nas empresas de serviços financeiros e telecomunicações. Destes, somente $11 \%$ (setor financeiro) e $8 \%$ (telecomunicações) dos clientes tornaram-se clientes lucrativos.

Reichheld (2003, p. 52-53) ressalta a importância de identificação dos promotores e dos detratores da marca, com potencial para desenvolverem um boca a boca positivo ou negativo. O autor identificou, não só que os detratores são responsáveis por 80 a $90 \%$ do boca a boca negativo, como também uma relação entre o boca a boca positivo e desempenho de vendas. Portanto vendas é uma métrica de avaliação do boca a boca positivo e o percentual de clientes que indicam a intenção de recomendar a empresa um previsor do potencial de boca a boca positivo (REICHHELD, 2003, p.47).

Para Gupta et al (2011, p.10), algumas métricas são páginas vistas, acompanhamento de buzz marketing gerados nas redes e número de fãs. Os autores também mencionam softwares capazes de acompanhar e mensurar o comportamento.

Taylor (2005, p. 27) reitera as dificuldades em medir os resultados do buzz marketing e cita as empresas Intelliseek e BuzzMetrics que usam a combinação de tecnologia com análise de comportamento de consumidores para medir o buzz marketing. 
Em 2005, a Intelliseek acompanhava seis mil comunidades online, 45 mil grupos e mais de 17 milhões de blogs. Sua ferramenta BlogPulse Web funciona como uma janela para observar o que ocorre no mercado online. Um exemplo de apuração que pode ser feita por este recurso é a identificação de foram realizados 40 posts - menções publicadas nas redes sociais, blogs, comunidades online, fóruns e demais plataformas de CGM - sobre os temas mais proeminentes acessados. Em 2006, a BuzzMetrics comprou a Intelliseek e tornou-se Nielsen BuzzMetrics.

O BuzzMetrics em 2011, acompanhava cerca de 100 milhões de blogs, redes sociais, comunidades e outras plataformas de CGM no mundo. Em 2012, o BuzzMetrics monitorava 4,5 milhões de blogs, 70.000 fóruns e 50 milhões de comentários em língua portuguesa.

A ferramenta propõe além da contagem das menções, analisar o conteúdo das mensagens e agregar valor ao CGM, por meio das seguintes avaliações:

Métricas comportamentais:

i) como os consumidores se sentem em relação às marcas, produtos e serviços;

ii) de que forma as conversas fortalecem ou enfraquecem a marca;

iii) como campanhas offline e online repercutem na internet;

iv) identificação dos internautas promotores, evangelistas, que advogam favoravelmente às marcas.

Métricas relativas à marca e setor de atuação:

iv) especificidades sobre a marca, organização e ofertas que são discutidas na internet;

v) por meio do mapeamento dos posts, mapear a reputação da marca;

vi) eventos, tendências e questões que podem influenciar o setor de atuação da empresa e gerar um buzz marketing.

Além do BuzzMetrics, outra ferramenta identificada para a análise das redes sociais é o VideoCensus do IBOPE (Instituto Brasileiro de Opinião Pública e Estatística), batizada em inglês de average attentiveness score. Este serviço faz a avaliação de vídeos postados por meio da atribuição de uma nota correspondente à qualidade da experiência 
do espectador em relação ao vídeo e ao conteúdo publicitário. Um usuário que minimizou a janela, por exemplo, tem pontuação inferior à de quem a manteve a janela aberta o tempo todo (IBOPE, 2010).

A nota é gerada a partir do rastreamento e da análise de todos os eventos relacionados ao vídeo desde o momento em que um usuário começou a assistir a reprodução:

i) o tempo médio assistido pelos espectadores;

ii) conteúdos mais acessados;

iii) número de vezes que os vídeos são reproduzidos.

O Quadro 7 sumariza as métricas levantadas para as diferentes ações de comunicação de marketing.

Quadro 7 - Métricas do mix de comunicação offline e online

\begin{tabular}{|c|c|}
\hline $\begin{array}{c}\text { Elemento do mix de } \\
\text { Comunicação } \\
\text { offline e online }\end{array}$ & \multicolumn{1}{|c|}{ Métricas } \\
\hline \multicolumn{1}{|c|}{ FERRAMENTAS TRADICIONAIS } \\
\hline Propaganda & $\begin{array}{l}\text { - Métricas financeiras: volume de vendas; giro de estoque e } \\
\text { contribuição de lucros (LAVIDGE; STEINER, 1961; KOKKINAKI; } \\
\text { AMBLER, 1999; JUNG; ROBINSON, 2005); } \\
\text { - Métricas de comportamento do consumidor quantitativas: } \\
\text { - penetração; } \\
- \text { número de usuários; } \\
\text { - lealdade; } \\
- \text { ganhos/perdas e churn de clientes (KOKKINAKI; AMBLER, } \\
\text { 1999); } \\
\text { - Métricas de comportamento do consumidor: } \\
\text { - qualitativas: motivação, preferências de clientes, expectativas, } \\
\text { percepção, atitude e nível de satisfação (JUNG; ROBINSON, 2005); } \\
\text { - qualitativas de efeitos de Lavidge e Steiner (1961) lembrança } \\
\text { (recall), consciência (awareness), conhecimento, simpatia, preferência } \\
\text { e intenção de compra; } \\
- \text { quantitativas - satisfação e lealdade dos clientes e número de } \\
\text { clientes (DAY; WENSLEY,1988; ANDERSON; SULLIVAN, 1993; } \\
\text { FORNELL } \text { et al, 1996). } \\
\text { - ROI em comunicação em relação ao custo de oportunidade do capital } \\
\text { da empresa (GUISSONI; NEVES, 2011). } \\
\text { - Impacto dos investimentos em comunicação no VPL de todos os }\end{array}$ \\
\hline
\end{tabular}




\begin{tabular}{|c|c|}
\hline & $\begin{array}{l}\text { fluxos de caixa futuros. (GUISSONI; NEVES, 2011). } \\
\text { - Ativos de marketing como brand equity e customer equity. } \\
\text { (GUISSONI; NEVES, 2011; BARWISE, 1993; AAKER; JACOBSON } \\
\text { 1994; AAKER, 1996a; KELLER, 1993; 1998); }\end{array}$ \\
\hline $\begin{array}{c}\text { Relações Públicas } \\
\text { e } \\
\text { Publicidade }^{1}\end{array}$ & $\begin{array}{l}\text { - Número de produtos de PR; número de mídias sobre produtos de PR. } \\
\text { - Colunas; centímetros; tempo no ar, publicações na mídia X circulação } \\
\text { ou alcance, custo de propaganda, inclinações positivas e negativas, } \\
\text { mensagens-chave, avaliação do alcance dos objetivos por meio de } \\
\text { pesquisa (FREITAG, 1998). } \\
\text { - Impacto na mídia, impacto, quantidade e percentual de artigos } \\
\text { positivos e negativos por asunto, por publicação, por repórter e junto } \\
\text { ao público específico (BELCH; BELCH, 2008). } \\
\text { - Auditoria, pesquisas de atitude, focus groups e estudos específicos } \\
\text { com análise fatorial e mapa perceptual (BELCH; BELCH, 2008; } \\
\text { LINDENMANN, 1993). }\end{array}$ \\
\hline Patrocínio & $\begin{array}{l}\text { - Aumento de vendas e participação de mercado (STOTLAR, 1998; } \\
\text { MEENAGHAN, 1998; SMOLIANOV; SHILBURY, 2005). } \\
\text { - Preços de ações (FARRELL; FRAME, 1997; MIYAZAKI; } \\
\text { MORGAN, 2001; OZTURK et al, 2004; CORNWELL et al, 2005). } \\
\text { - Relacionar patrocínio ao alcance de resultados específicos de negócio } \\
\text { (SMOLIANOV; SHILBURY, 2005). } \\
\text { - Modelo que avalia impacto e intenção de compra em termos de atitud } \\
\text { em relação à marca (MARTENSEN et al,2007). } \\
\text { - Redução da participação de mercado da concorrência (HANSEN; } \\
\text { SCOTWIN, 1995; IRWIN; SUTTON, 1994). } \\
\text { - Atenção, compreensão, envolvimento emocional, apreciação e } \\
\text { comprometimento (SponsorMap, 2011). } \\
\text { - Envolvimento emocional do público com o evento patrocinado } \\
\text { (CAMERON, 2003). } \\
\text { - Custo do valor do tempo de exposição na cobertura de um evento } \\
\text { (KOTLER; KELLY, 2006). }\end{array}$ \\
\hline Promoção de venda: & $\begin{array}{l}\text { - Vendas (BELCH; BELCH , 2008; KOTLER; KELLER, 2006; } \\
\text { COUGHLAN et al, 2002; FARRIS et al 2007). } \\
\text { - Vendas incrementais ou impulso promocional, porcentagem de temp } \\
\text { em promoção, taxa de resgate de cupons, custos para promoções de } \\
\text { cupons e descontos, porcentagem de vendas com cupons ou descontos, } \\
\text { repasse de descontos e desconto médio (FARRIS et al 2007). }\end{array}$ \\
\hline Marketing Direto & - Aquisição e retenção (MILLER; WASHINGTON, 2011). \\
\hline
\end{tabular}




\begin{tabular}{|c|c|}
\hline & $\begin{array}{l}\text { - Custo Permissível por Pedido (CPPP) e Custo por Pedido (CPP) } \\
\text { (ROSENWALD, 2005). } \\
\text { - Lifetime Value do cliente (LTV) ou CLV (SHIMP, 2002; } \\
\text { ROSENWALD, 2005; BAKER, 2005). } \\
\text { - Custo por Resposta (CPR) e Custo por Venda (CPV) (BAKER, 2005 }\end{array}$ \\
\hline Venda Pessoal & $\begin{array}{l}\text { - Total de vendas, previsão de potencial de vendas, remuneração da } \\
\text { força de vendas, carga de trabalho, eficácia da equipe de vendas e funil } \\
\text { de vendas (BELCH; BELCH, 2008; FARRIS et al, 2007). }\end{array}$ \\
\hline & FERRAMENTAS COMPLEMENTARES \\
\hline Product Placement & $\begin{array}{l}\text { - Memória e atitude do consumidor (COWLEY; BARRON, 2008; } \\
\text { BRESSOUD et al, 2010; RUSSELL, 2002). }\end{array}$ \\
\hline Merchandising & $\begin{array}{l}\text { - Vendas e observação do impacto visual. (QUELCH e CANNON- } \\
\text { BONVENTRE, 1983); } \\
\text { - Rotatividade dos estoques e pesquisa de avaliação de ações de } \\
\text { experimentação (POPAI, 2011). }\end{array}$ \\
\hline Marketing Digital & $\begin{array}{l}\text { - Exposições ou ODV, impactos, taxa de cliques, visitas às páginas } \\
\text { (pageviews), visitantes ou visitantes únicos, fluxo de cliques, taxa de } \\
\text { abandono de compras custo por exposição, custo por clique, custo por } \\
\text { pedido, custo por cliente adquirido, (FARRIS et al, 2007). } \\
\text { - Métricas de eficácia da propaganda: função de resposta à frequência } \\
\text { linear, função de resposta à frequência da curva de aprendizado, } \\
\text { funções de resposta de frequência limiar, resposta à frequência efetiva; } \\
\text { alcance efetivo, percentual de presença (FARRIS et al, 2007). } \\
\text { - Relacionamento com os clientes, taxa de conversão e de recuperação } \\
\text { de clientes inativos (FOROOTAN, 2008). } \\
\text { - Métricas específicas do Google e YouTube: } \\
\text { - tráfego, links de maior impacto, picos de visitas, o tempo de } \\
\text { permanência e novos destinos tomados pelos usuários (GOOGLE, } \\
\text { 2011); } \\
\text { - vídeos - número de acessos, quantos avaliaram e quantas } \\
\text { avaliações favoráveis e desfavoráveis (YOU TUBE, 2011) }\end{array}$ \\
\hline $\begin{array}{l}\text { Eventos } \\
\text { Técnicos }\end{array}$ & $\begin{array}{l}\text { - Dados de entrada de público, reação e valor percebido, informação, } \\
\text { conhecimento, habilidades e contatos estabelecidos com participantes } \\
\text { aplicação e implementação do conteúdo do evento (PHILLIPS et al, } \\
\text { 2008). }\end{array}$ \\
\hline $\begin{array}{c}\text { Marketing de } \\
\text { Relacionamento }\end{array}$ & $\begin{array}{l}\text { - LTV (SHIMP, 2002, ROSENWALD, } 2005 \text { e BAKER, 2005). } \\
\text { - Clientes, recência, taxa de retenção, rentabilidade do cliente, valor de } \\
\text { duração do cliente, previsão do valor de duração, custo médio de } \\
\text { aquisição e custo médio de retenção (FARRIS et al, 2007). }\end{array}$ \\
\hline \multicolumn{2}{|r|}{ FERRAMENTAS INOVADORAS } \\
\hline Advertainment & $\begin{array}{l}\text { - Offline: métricas de patrocínio; } \\
\text { - Online: Métricas aplicáveis ao marketing digital }\end{array}$ \\
\hline
\end{tabular}




\begin{tabular}{|c|c|}
\hline & - Lembrança do vídeo (FARRIS et al, 2007) \\
\hline $\begin{array}{l}\text { Marketing Viral, } \\
\text { Buzz marketing e } \\
\text { Redes Sociais }\end{array}$ & $\begin{array}{l}\text { - Métricas aplicáveis ao marketing digital. } \\
\text { - Acompanhamento do comportamento online em redes sociais, blogs, } \\
\text { fóruns e comunidades online (PHELPS et al, 2004). } \\
\text { - Métricas de publicidade geradas pela campanha de marketing viral } \\
\text { (KHERMOUCH; GREEN, 2001). } \\
\text { - Intenções de boca a boca, referências, efeitos destas referências e } \\
\text { lucratividade dos clientes referenciados (KUMAR et al, 2007). } \\
\text { - Vendas relacionadas ao boca a boca positivo (REICHHELD, 2003). } \\
\text { - Métricas comportamentais: } \\
\text { - páginas vistas, acompanhamento de buzz, marketing gerados nas } \\
\text { redes e número de fãs (GUPTA et al, 2011) } \\
\text { - como os consumidores se sentem em relação às marcas, produto } \\
\text { e serviços, } \\
\text { - como as conversas fortalecem ou enfraquecem a marca, } \\
\text { - como campanhas offline e online repercutem na internet } \\
\text { - identificar internautas evangelistas que advogam favoravelmente } \\
\text { às marcas (BuzzMetrics, 2011). } \\
\text { - Métricas relativas à marca e ao setor de atuação: } \\
\text { - especificidades sobre a marca; } \\
\text { - organização e ofertas que são discutidas na internet; } \\
\text { - mapeamento dos posts para identificar a reputação da marca; } \\
\text { - eventos, tendências e questões que podem influenciar o setor de } \\
\text { atuação da empresa e podem ocasionar um buzz marketing. } \\
\text { (BuzzMetrics, 2011). }\end{array}$ \\
\hline
\end{tabular}

${ }^{1}$ São adotadas as mesmas métricas para PR e Publicidade

FONTE: Elaborado pela autora

A partir do Quadro 7, que sumariza as métricas das ações offline e online segundo a classificação proposta por Ogden e Crescitelli (2008, p. 24), é possível identificar a relevância que alguns objetivos estabelecidos no planejamento da CIM representa para a apuração dos resultados atingidos pelos investimentos em comunicação. Como por exemplo, vendas, construção de imagem de uma marca e incremento de fidelidade de clientes para a avaliação dos resultados destes investimentos.

A métrica vendas, além de relacionada aos objetivos de planejamento, é uma das mais antigas métricas. Ela é adotada em quatro das seis ferramentas de comunicação de marketing tradicionais: propaganda, patrocínio, promoção de vendas e venda pessoal. 
No bloco de ferramentas complementares, vendas figura somente em merchandising. Dentre as ações de comunicação inovadoras, a métrica vendas é indicada em advertainment, uma vez que se adotam as métricas de patrocínio e marketing viral, buzz marketing e redes sociais, agrupadas num único bloco de ferramentas de comunicação.

Em relação às métricas de ações online, contatou-se a adoção de algumas específicas, viáveis somente nesta mídia ou restritas às empresas prestadoras de serviços online, como Google, YouTube e Facebook. Além dessas métricas exclusivamente online, é possível aplicar métricas tradicionais offline em ações realizadas na internet.

A etapa relativa à fundamentação teórica sobre os temas comunicação de marketing offline e online e métricas do mix de comunicação permitiu desenvolver um arcabouço teórico que sustentará a etapa empírica desta pesquisa.

Em seguida serão apresentadas informações específicas do setor estudado que permitiram conhecer particularidades sobre os canais de comunicação e relacionamento com os clientes de instituições bancárias e favoreceram a etapa de coleta de dados.

A fase empírica deste estudo que será apresentada após o capítulo dois, buscará entender como a amostra estudada gerencia a avaliação dos investimentos em comunicação e propor um modelo a partir da constatação de como esses profissionais de comunicação lidam na prática com as diferentes ações de comunicação offline e online, as métricas de avaliação dos investimentos em comunicação, diferentes mídias e públicos-alvo. 


\section{O SETOR DE BANCOS}

Dados da Febraban relativos a 2010 apontam haver 157 bancos operando no Brasil, dos quais 88 privados, com ou sem participação estrangeira, 60 privados com controle estrangeiro e nove públicos, federais e estaduais.

Em relação à concentração das instituições no setor de bancos, de acordo com dados da Febraban de 2010, os três primeiros bancos detinham quase $50 \%$ do total de ativos e os dez primeiros, excluindo-se o BNDES, respondem por cerca de $80 \%$ dos ativos.

Estudo do Ministério da Fazenda (2011) aponta que em 2002, o volume de crédito representava pouco mais de $24 \%$ do PIB e que, em 2010, este percentual passou para 46,6\% do PIB. Esta taxa tem crescido nos anos recentes, mas ainda é uma taxa de penetração bancária (crédito/PIB) baixa, quando comparada a países mais desenvolvidos.

Em 2010, havia 141 milhões de contas correntes no Brasil, tendo havido um aumento de 5,7\% no número em relação ao ano anterior (FEBRABAN, 2011).

Segundo dados da Febraban (2011), apesar da ampliação da importância relativa da internet, os bancos continuam investindo na expansão da rede de atendimento. Esta rede inclui além de agências e dos postos eletrônicos de autoatendimento (ATM), os postos tradicionais. Os postos tradicionais são compostos por:

i) Postos de Atendimento Bancário (PAB);

ii) Postos de Arrecadação e Pagamentos (PAP);

iii) Postos Avançados de Atendimento (PAA);

iv) Postos de Atendimento Cooperativo (PAC);

v) Postos de Atendimento ao Microcrédito (PAM);

vi) Postos Avançados de Crédito Rural (PACRE);

vii) Postos de Compra de Ouro (PCO);

viii) Unidades Administrativas Desmembradas (UAD). 
No período 2000-2010, o número de agências passou de 16,4 para 19,8 mil (cerca de $20 \%$ ) e os postos tradicionais cresceram aproximadamente 25\%. Em 2010, pela primeira na década, houve um recuo no número de agências que passou de 20 mil para 19,8 .

Em contrapartida, ao longo dos anos 2000-2010, o total de ATMs instaladas cresceu de 14,5 para 45 mil (210\%), tendo aumentado $43 \%$ somente no ano de 2010 . Este movimento é uma resposta à busca de conveniência pelos correntistas. Em 2011, esse canal foi o mais usado pelos correntistas - $31 \%$ do total de movimentações (FEBRABAN, 2011).

Por atenderem tanto a clientes PF quanto clientes PJ, os bancos são instituições com caráter B2C e B2B e dispõem de uma variedade de canais de atendimento e realização de negócios. Na Figura 19, podem ser observados os canais mais significativos para a realização de operações e relacionamento com os clientes dos bancos.

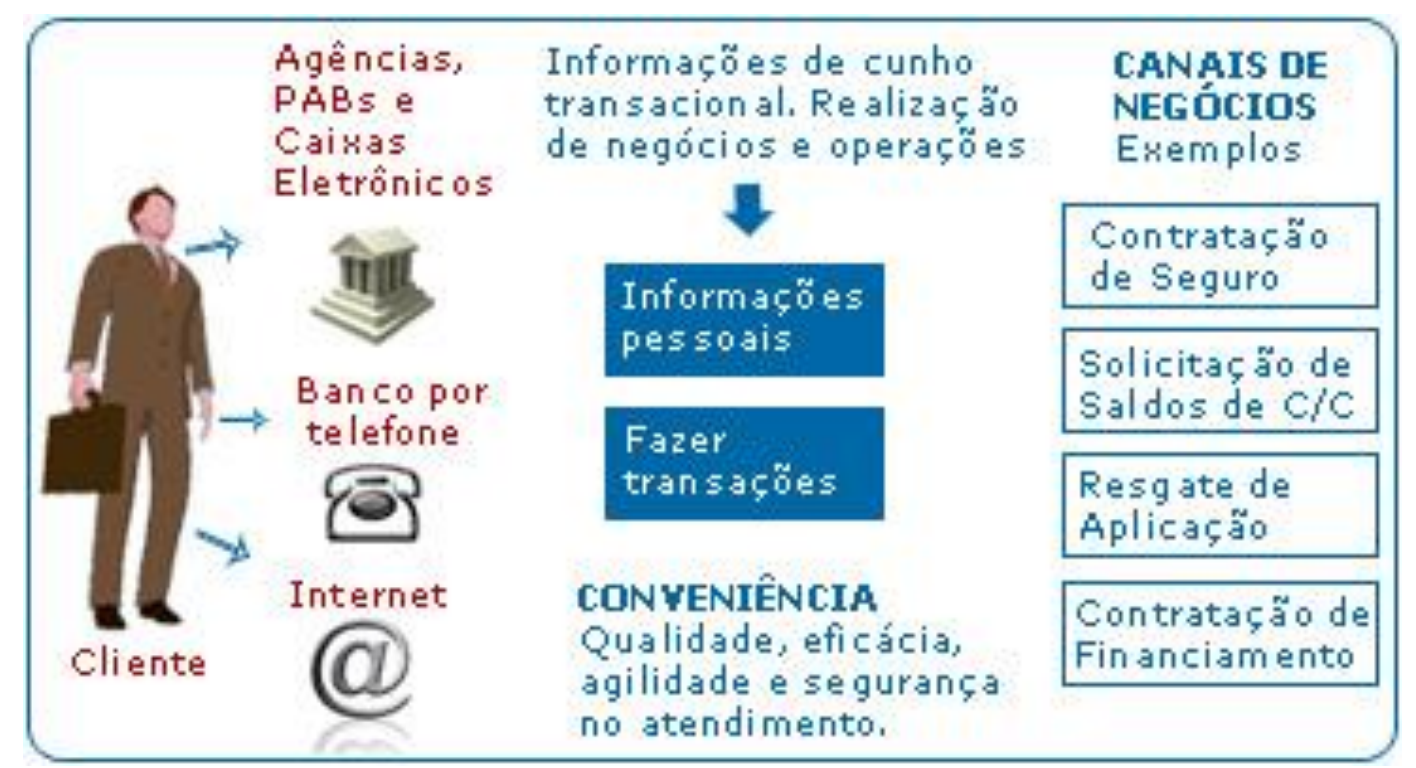

\section{Figura 19 - Canais de negócios dos bancos}

FONTE: FEBRABAN; 2011.

De acordo com a Figura 19, além das agências bancárias, por meio das quais os clientes podem ser atendidos pessoalmente por caixas ou gerentes, o sistema bancário brasileiro oferece uma vasta rede de canais, tais como, PABs e ATMs, atendimento por telefone e 
internet, que permitem tanto esclarecimento sobre dúvidas, quanto realização de operações, negócios e transações.

\subsection{A importância da internet para o setor bancário no Brasil}

Em relação ao mercado brasileiro, segundo estudo da Falke Information publicado na EMIS - Emerging Markets Information Service (FALKE INFORMATION, 2011), a audiência da internet brasileira foi 73,7 milhões de pessoas em 2010, sendo 47,2\% pertencentes às classes A e B. O uso desta mídia vem se popularizando cada vez mais, sobretudo com o ingresso de usuários pertences às classes CDE.

De acordo com Batista (2001, p.49),

estabelecer relacionamentos pressupõe a utilização de mídias que possibilitem o fluxo da informação em dois sentidos - empresa/cliente e cliente/empresa. Entre as mídias mais utilizadas nesse sentido, destaca-se a internet, que trouxe consigo a possibilidade da utilização ode técnicas interativas de comunicação.

Segundo levantamento feito nos sites dos bancos em novembro de 2011, estas instituições têm usado amplamente as redes sociais, sobretudo o Facebook. Os principais objetivos de uso das redes sociais pelos bancos são:

i) comunicação com seus clientes;

ii) divulgação de campanhas;

iii) atendimento a questionamentos que, além de esclarecidos, são postados posteriormente no site da instituição, na página do produto no Facebook ou, em menor frequência no Twitter.

Além de relacionamento, outra finalidade das redes é proporcionar experiências e serviços únicos a cada cliente (PRICE, 2010, p. 28), o que foi confirmado na análise dos sites dos bancos.

As instituições financeiras no Brasil destacaram-se no uso da tecnologia por muitos anos ao conectarem as agências, formaram uma rede formidável, dominaram as tecnologias de internet banking e continuam avançando. O BC aponta um crescimento 
de 64\% no uso desse instrumento desde 2006 (CUCOLO, 2010). Em 2010, os gastos desta natureza totalizaram $\mathrm{R} \$ 22$ bilhões e representaram um avanço de 5,5\% em relação ao ano anterior.

Dados do mais recente relatório anual da Febraban (2011), indicam que, entre 2000 e 2010, o percentual de correntistas que utiliza internet banking, ou operações bancárias pela internet saltou de oito para 37\%. Nesse período, o incremento no número de transações pela internet foi de quase 18 vezes, tendo passado de 729 mil para 12,8 bilhões de transações. Em 2010, a internet foi o segundo canal preferido pelos brasileiros para a realização de operações bancárias, com $23 \%$ do total das transações e um incremento de $27,4 \%$ em relação ao ano anterior.

O cheque vem diminuindo sua importância no total de transações. Em 2010, foram compensados 1,1 bilhão de documentos contra 1,2 bilhão, em 2009. A queda de 9\% confirma o movimento descendente ao longo da década (FEBRABAN, 2011).

O número de contas de mobile banking, que permitem aos correntistas realizar transações por celulares, smartphones e outros dispositivos móveis, ainda representa um número pouco significativo no total de transações. O avanço de $71,4 \%$ sobre 2009 permitiu o alcance de 2,2 milhões de contas. Estima-se que esta tendência de ascensão se mantenha nos próximos anos (FEBRABAN, 2011).

Considerando-se os objetivos deste estudo, os bancos foram escolhidos devido a alguns critérios, tais como:

i) Serem empresas de serviços de massa, que atuam num mercado competitivo;

ii) $\mathrm{O}$ volume de gastos em comunicação de marketing;

iii) A variedade dos investimentos realizados em comunicação de marketing online e offline;

iv) As características dos serviços prestados que envolvem estabelecimento de um relacionamento de longo prazo e, portanto investimentos, marketing direto, uso intensivo de marketing digital e venda pessoal, por meio do gerente de conta que também exerce papel fundamental no marketing de relacionamento. 
Devido às aquisições e fusões ao longo dos últimos anos - Banespa por Santander em 2000, Banco Mercantil de São Paulo pelo Bradesco em 2002, Deutsche Bank pelo Bradesco em 2002, Banco Bilbao Vizcaya (BBVA) pelo Bradesco em 2003, BankBoston por Itaú em 2006, Real por Santander em 2007, Unibanco e Itaú em 2008 , as instituições bancárias realizam investimentos significativos em comunicação para esclarecimentos sobre mudanças e fortalecimento da marca que prevaleceu após a operação fusão ou aquisição.

Para confirmar a relevância do volume investido, foi realizada análise dos levantamentos realizados pela Monitor Evolution, pesquisa que acompanha os gastos em publicidade e publica relatórios anuais sobre os trinta maiores anunciantes do Ibope no período 2007-2010. Esta análise permitiu identificar que, dentre os 30 maiores anunciantes no Brasil, as instituições que pertencem ao setor de bancos foram responsáveis, em média, por mais de $12 \%$ do total investido em propaganda ao ano neste período.

Outro fato que indica a intensidade dos gastos em comunicação é que, de acordo com relatório da consultoria Interbrand de 2011, três instituições financeiras figuram entre as quatro empresas brasileiras com maior valor de marca: Itaú ( $\mathrm{R} \$ 24$ bi), Bradesco ( $\mathrm{R} \$ 13$ bi) e Banco do Brasil ( $\mathrm{R} \$ 11$ bi), ocupando respectivamente, a primeira, segunda e quarta posições no ranking Brasil de marcas mais valiosas. No ano anterior, a marca Itaú havia sido avaliada em $\mathrm{R} \$ 20,7$, tendo dobrado de valor em relação a 2008, ano em que foi feita a fusão com o Unibanco. (INTERBRAND, 2011).

Pesou na escolha também o fato de as instituições financeiras serem empresas de serviços com foco em marketing de relacionamento e pertencerem a um setor bastante estudado na literatura sobre o tema (BERRY, 1995; GRÖNROOS, 1994; McKENNA, 1993; GORDON, 1998; GUMMESSON, 2010).

De acordo com Las Casas (2007, p. 31-32), uma das características do setor bancário, no que tange a aplicação do marketing de relacionamento, é o fato dos bancos poderem "estabelecer relações permanentes com seus clientes" tornando-se difícil à concorrência conquistar os clientes fidelizados por outras instituições. Segundo Las Casas (2007, 
p.36), para sustentar os relacionamentos, os bancos têm buscado conhecer melhor seus clientes e oferecer produtos de longo prazo que os mantenham na instituição.

$\mathrm{O}$ último aspecto que pesou favoravelmente à escolha deste setor foi o fato de as instituições financeiras investirem numa variada gama de elementos do mix de comunicação e, na maioria dos casos, com alta intensidade de adoção, conforme observado no Quadro 8.

\section{Quadro 8 - Diversidade e intensidade de uso das ferramentas de comunicação offline e online pelos bancos brasileiros}

\begin{tabular}{|c|c|}
\hline $\begin{array}{c}\text { Elemento do Mix de } \\
\text { Comunicação }\end{array}$ & Intensidade de Uso \\
\hline Propaganda & Alta \\
\hline Relações públicas & Alta \\
\hline Publicidade & Alta \\
\hline Patrocínio & Alta \\
\hline Promoção de vendas & Baixa \\
\hline Marketing direto & Alta \\
\hline Venda pessoal & Alta para B2B e para clientes \\
& B2C alta renda \\
\hline Product placement & Baixa \\
\hline Merchandising & Média \\
\hline Marketing digital & Alta \\
\hline Eventos técnicos & Baixa \\
\hline Marketing de relacionamento & Alta \\
\hline Advertainment & Baixa \\
\hline Marketing viral & Baixa \\
\hline Buzz marketing & Baixa \\
\hline Redes sociais & Alta \\
\hline
\end{tabular}

FONTE: Elaborado pela autora a partir de análise de informações públicas

A partir das informações apresentadas neste capítulo, conclui-se que o setor de bancos adota canais particulares como ATM e internet banking, prioriza relacionamento e investe numa ampla variedade de ações de comunicação offline e online de forma significativa, havendo raras exceções de ferramentas de comunciação pouco usadas, como: promoção de vendas, Product placement, Eventos técnicos, Advertainment, Marketing viral e Buzz marketing.

Espera-se que na etapa empírica em que serão indagadas as ferramentas de comunicação mais significativas sejam mencionadas as com alta intensidade de uso. 


\section{MÉTODO DA PESQUISA EMPÍRICA}

A fundamentação teórica realizada na primeira parte da pesquisa possibilitou obter maior conhecimento sobre o objeto deste estudo: métricas dos mix de comunicação offline e online e demais temas relacionados ao seu entendimento.

Neste capítulo é feita a descrição do tipo da pesquisa. Além disso, aborda-se o método de coleta de dados, a seleção das empresas pesquisadas e o procedimento analítico.

\subsection{Metodologia de Pesquisa}

As pesquisas podem ser classificadas segundo os objetivos, características e método de pesquisa em exploratória, conclusiva descritiva e conclusiva causal ou correlacional (AAKER et al, 2001, p. 94; MALHOTRA, 2006, p.99; MATTAR, 2008, p. 7-14; SAMPIERI et al, 2006, p. 99-103).

A pesquisa conclusiva envolve objetivos bem definidos, coleta de dados estruturada e trata da solução de problemas ou avaliação de uma ação a ser tomada.

A pesquisa exploratória é recomendada para estágios iniciais de estudo em que o pesquisador busca aprimorar seu conhecimento sobre um tema pouco pesquisado ou que tenha muitas lacunas (SAMPIERI et al, 2006, p.99-100; MATTAR, 2008, p. 7-8).

Tendo em vista os objetivos desta pesquisa de sistematização das métricas de avaliação de investimentos em comunicação de marketing offline e online e o estágio de conhecimento sobre o tema, este estudo adota uma metodologia exploratória, pois os estudos exploratórios permitem descobrir novos conhecimentos.

\subsection{Método de Coleta}

De acordo com Lakatos e Marconi (1989, p 41-42), este método corresponde ao "conjunto das atividades sistemáticas e racionais que, com maior segurança e economia, 
permite alcançar o objetivo - conhecimentos válidos e verdadeiros, traçando o caminho a ser seguido (...)".

A pesquisa adotou uma abordagem exploratória e utilizou procedimento qualitativo. Segundo Godoy (1995, p.58), “a pesquisa qualitativa não procura enumerar e/ou medir os eventos estudados, nem emprega instrumental estatístico na análise de dados. Parte de questões ou focos de interesse amplos, que vão se definindo à medida que o estudo se desenvolve".

Creswell (2007, p. 185) identifica quatro tipos de coletas de dados aplicáveis à pesquisa exploratória: i) observação, ii) entrevistas, iii) análise documental; iv) análise de material audiovisual.

A técnica de coleta adotada foi a entrevista individual, também chamada de entrevista em profundidade. A entrevista reconhecida como método de coleta de dados em pesquisas científicas, diferencia-se, segundo Valles (1997, p. 180, apud GODOI; MATTOS, 2006, p.303), porque:

i) na entrevista, a participação do entrevistado e entrevistados conta com expectativas explícitas;

ii) o entrevistador estimula o entrevistado a falar;

ii) aos olhos do entrevistado, o entrevistador é o encarregado de organizar e manter a conversação.

Godoi e Mattos (2006, p. 304) apontam três principais modalidades de entrevistas qualitativas:

i) entrevista convencional livre em torno de um tema, na qual as perguntas surgem no contexto e curso natural da interação, sem que haja uma previsão de perguntas nem de reações a elas;

ii) entrevista padronizada aberta, na qual se adota uma lista de perguntas abertas ordenadas e redigidas da mesma forma, para todos os entrevistados, mas as respostas são abertas; 
iii) entrevista baseada num roteiro, caracterizada por conferir ao entrevistador flexibilidade para ordenar e formular as perguntas durante a entrevista.

Nesta pesquisa, foi aplicada a terceira modalidade, ou seja, as entrevistas foram conduzidas com base num roteiro, sem rigidez na ordem e na formulação das perguntas.

Segundo classificação de Godoi e Mattos (2006, p. 304), na entrevista baseada em roteiro, o entrevistador tem liberdade para desenvolver cada situação na direção que considere adequada.

Creswell (2007, p. 182) indica diferentes formas de realizar as entrevistas:

i) conduzir entrevista não estruturada, aberta e tomar notas;

ii) conduzir entrevista não estruturada, aberta, gravá-la e transcrevê-la;

iii) conduzir entrevista semiestruturada, gravá-la e transcrevê-la;

iv) conduzir entrevista com grupo de foco, gravá-la e transcrevê-la;

v) conduzir diferentes formas de entrevistas: por e-mail, pessoalmente, grupo de foco (pessoalmente ou pela internet), por telefone.

Nesta pesquisa, optou-se pela terceira modalidade, entrevistas semiestruturadas, gravadas para posterior transcrição.

Em relação ao método de comunicação adotado, segundo classificação de Selltiz et al (1975, p. 294-295), foi utilizado o semiestruturado não disfarçado, que se caracteriza por revelar os propósitos do estudo aos respondentes, sem uma estruturação predefinida das perguntas e das respostas. Para estes autores, para alguns problemas de pesquisa como o da presente tese, é recomendada uma abordagem flexível nas entrevistas, sem definição prévia de perguntas exatas feitas pelo entrevistador. Os autores explicam que esse tipo de entrevista atinge seu objetivo quando as respostas do entrevistado são espontâneas e não forçadas. No entanto, Selltiz et al (1975, p. 294-295) advertem que a liberdade do entrevistador é a principal desvantagem dessas entrevistas, pois a flexibilidade pode comprometer a possibilidade de comparação das entrevistas e dificultar a análise dos dados. Para minimizar a possibilidade deste problema, foi adotado um roteiro de entrevistas cujo conteúdo está apresentado no Apêndice 1. 
Procurou-se seguir o roteiro na íntegra em todas as entrevistas, mas sem rigor da ordem, uma vez que a espontaneidade das respostas implicou, em alguns casos, a antecipação de informações, antes mesmo de ser feita a pergunta. Além disso, nem todas as perguntas foram respondidas devido ao esgotamento de informações sobre o tema abordado ou inexistência de algo a ser mencionado. Outro motivo para diferenças no conteúdo levantado é o fato de alguns bancos usarem uma única métrica ou não compararem as métricas de ferramentas de comunicação offline com as ações online. Em algumas instituições, o entrevistado atuava numa área específica, como por exemplo, relacionamento com clientes e suas respostas foram restritas a sua área de atuação. Esta restrição foi contornada por meio da realização de mais de uma entrevista em algumas instituições.

Foram conduzidos dois pré-testes do roteiro com especialista em comunicação de marketing para avaliar o conteúdo e o entendimento das perguntas, para estimar um tempo médio necessário para a realização da entrevista, uma vez que a disposição para participar é influenciada pelo tempo estimado e, por último para aprimorar a habilidade da pesquisadora de conduzir as entrevistas. Esta etapa da pesquisa permitiu a revisão e aprimoramento da investigação, conforme sugerem Richardson et al (2008).

O primeiro pré-teste foi realizado com o gerente de marketing de uma instituição de ensino, responsável pelo orçamento e pelas decisões de comunicação. A decisão de escolha de uma empresa fora do universo desta pesquisa decorreu de dois fatos. $\mathrm{O}$ primeiro foi o intuito da pesquisadora de preservar a escassa amostra de seu estudo e o segundo deveu-se à conveniência de acessar o entrevistado com um perfil adequado a responder sobre as decisões de comunicação de marketing e a avaliação dos resultados atingidos. A instituição escolhida foi considerada qualificada por investir em ações offline tais como propaganda, RP, patrocínio, venda pessoal e realizar eventos de cunho técnicos, como workshops e palestras com a finalidade de vendas e relacionamento. A referida escola também investe em marketing digital com o intuito de venda e relacionamento e faz monitoramento contínuo do público em geral nas redes sociais.

Foi possível identificar a necessidade de alguns ajustes na formulação das perguntas do roteiro e, o mais importante, constatou-se a inabilidade da pesquisadora de tomar notas durante a entrevista e que, tendo em vista o foco na identificação das principais ações de 
comunicação offline e online e as métricas de avaliação destas ações, o tempo necessário para a realização das entrevistas giraria em torno de 30 minutos. A partir deste pré-teste, a pesquisadora passou a adotar um gravador.

O segundo pré-teste foi feito com o gerente de comunicação de um banco regional que, segundo relatório do Bacen, figura entre os 20 maiores bancos do Brasil em ativos. Por se tratar de uma empresa do setor estudado, foi possível confirmar a adequação do roteiro, da forma de registro da entrevista - gravador -, o tempo estimado e aprimorar a desenvoltura da entrevistadora em conduzir a entrevista semiestruturada com roteiro.

Foram realizadas dez entrevistas, uma delas invalidada, pois o entrevistado interrompeu a entrevista por temer revelar informações sigilosas. Dentre as nove entrevistas válidas para o estudo, cinco foram conduzidas pessoalmente, quatro por telefone e uma por Skype.

Todas as entrevistas foram gravadas, com o consentimento dos entrevistados. As gravações foram transcritas, objetivando-se “(...) eliminar as imprecisões das anotações de campo e ampliar a possibilidade de acesso público dos resultados, com elevado detalhamento", conforme sugerido por Godoi (2006, p. 314).

\subsection{Amostra}

Os bancos entrevistados foram selecionados dentre as dez maiores instituições financeiras do Brasil, conforme o relatório do Banco Central "50 Maiores Bancos e o Consolidado do Sistema Financeiro Nacional" (Anexo 1). A amostra foi nãoprobabilística, por acessibilidade.

As instituições entrevistadas, em ordem alfabética, foram: 1) Banco do Brasil (BB), 2) Banco Votorantim, 3) Bradesco, 4) Citibank, 5) Itaú, 6) HSBC e 7) Santander.

Ao decidir sobre quem e quantas pessoas entrevistar, Godoi e Mattos (2006, p. 310) recomendam considerar aspectos relacionados à acessibilidade e recursos disponíveis. 
Tendo em vista os critérios adotados para a seleção do universo entrevistado e o período disponível - outubro e novembro de 2011 - foram contatados profissionais de oito bancos a partir do final de setembro por e-mail e telefone. Houve dificuldade para marcar a entrevista com executivos em dois bancos. Num deles foi necessário recorrer a especialistas, profissionais que haviam trabalhado no banco.

Foram entrevistados um total de nove profissionais relacionados a sete bancos. Em duas instituições foram conduzidas duas entrevistas.

\subsection{Procedimentos Analíticos}

Collis e Hussey (2005, p. 238) apontam a falta de clareza dos métodos de análise dos dados qualitativos, pois "em alguns artigos publicados o pesquisador deve ter tido centenas ou talvez milhares de páginas de dados qualitativos, mas é difícil avaliar como eles foram sumarizados e estruturados para chegar às conclusões".

O método de análise escolhido foi análise de conteúdo, amplamente utilizado por sociólogos, historiadores e psicólogos para analisar a comunicação e que vem sendo adotado também pelos administradores. Collis e Hussey (2005, p. 238-240) indicam:

(...) trata-se de um método formal para análise de dados qualitativos, que consiste na conversão sistemática de textos em variáveis numéricas para a análise quantitativa de dados (...). O material analisado é qualificado em várias unidades de código que em geral são préconstruídas pelo pesquisador. (COLLIS; HUSSEY, 2005, p. 238-240)

A análise de conteúdo das entrevistas nesta pesquisa foi adotada conforme orientação de Bardin (2007, p. 121), segundo três estágios:

i) pré-análise;

ii) exploração do material com categorização das respostas;

iii) tratamento dos resultados, a inferência e a interpretação.

A Figura 20 ilustra o processo de análise do conteúdo e suas etapas. 
PRÉ-ANÁLISE

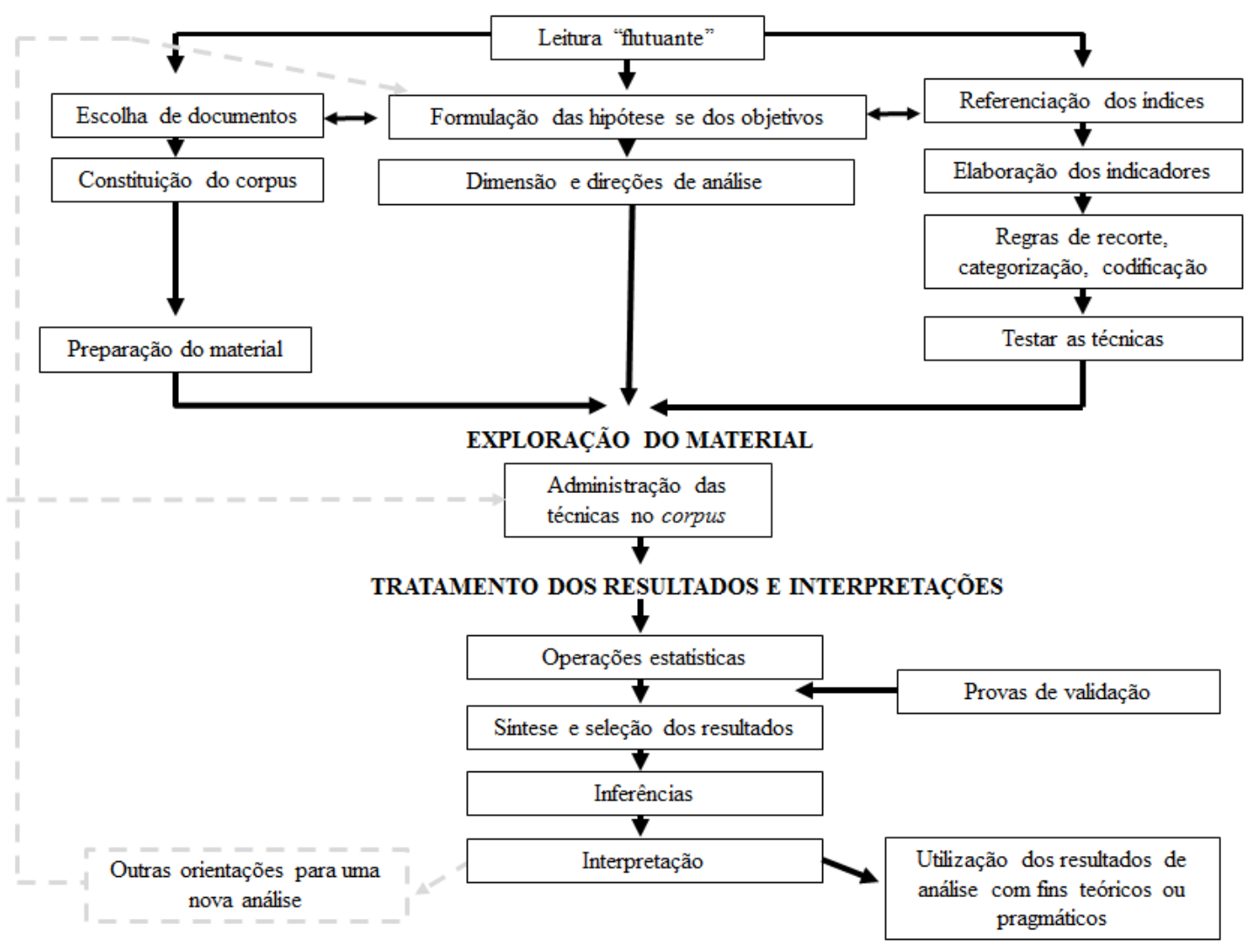

Figura 20 - Processo de análise de conteúdo

FONTE: BARDIN; 2007, p. 128.

A presente pesquisa percorreu a etapa de pré-análise, por meio de leitura sobre o objeto do estudo e posterior formulação dos objetivos de identificação das métricas adotadas para avaliação dos resultados atingidos pelos investimentos em comunicação online e off-line. Foi utilizada como referência a revisão de literatura sobre métricas de comunicação.

A segunda etapa de exploração do material coletado consistiu na categorização dos dados e envolve "uma operação de classificação de elementos constitutivos de um conjunto, por diferenciação e, seguidamente, por reagrupamento segundo o gênero (analogia), com os critérios previamente definidos" (BARDIN, 2007, p.111).

A definição das categorias deve obedecer a alguns critérios:

i) exclusão mútua que consiste na impossibilidade de cada elemento estar em mais de uma categoria; 
ii) homogeneidade é relacionada ao fato de cada registro estar numa única categoria;

iii) pertinência, que significa que uma categoria é relacionada ao conteúdo analisado e à fundamentação teórica a ela atribuída;

iv) objetividade e fidelidade, ou seja, os elementos de um mesmo material devem ser codificados da mesma forma, mesmo que submetidos a diversas análises, evitando-se subjetividade por meio de uma definição clara das categorias;

v) produtividade é pertinente ao fato de que o conjunto de categorias fornece resultados significativos em termos de inferências, hipóteses e dados exatos.

Cada categoria agrupa unidades de registro sob um título genérico em função de características comuns. De acordo com Bardin (2007, p. 111), os possíveis critérios para categorização são:

i) semântico - categorias temáticas com algum significado;

ii) lexical - classificação das palavras segundo o sentido;

iii) expressivo - categorias que classificam as diversas expressões da linguagem.

O critério adotado para a categorização foi o semântico, tendo como referência o tema das categorias de ferramentas de comunicação e métricas de avaliação dessas ferramentas.

A análise de conteúdo depende do tipo de comunicação (oral ou escrita) a que se dedica e do tipo de informação que se espera obter. No Quadro 9 estão apresentadas as possíveis áreas de aplicação da análise de conteúdo. 
Quadro 9 - Domínios de aplicação da análise de conteúdo

\begin{tabular}{|c|c|c|c|c|}
\hline \multirow[b]{2}{*}{$\begin{array}{l}\text { CÓDIGO E } \\
\text { SUPORTE }\end{array}$} & \multicolumn{4}{|c|}{$\begin{array}{c}\text { QUANTIDADE DE PESSOAS IMPLICADAS NA } \\
\text { COMUNICAÇÃA }\end{array}$} \\
\hline & $\begin{array}{c}\text { Uma pessoa } \\
\text { Monólogo }\end{array}$ & $\begin{array}{c}\text { Comunicação } \\
\text { dual } \\
\text { Diálogo }\end{array}$ & Grupo restrito & $\begin{array}{c}\text { Comunicação de } \\
\text { Massa }\end{array}$ \\
\hline $\begin{array}{l}\text { LINGUÍS- } \\
\text { TICO } \\
\text { Escrito }\end{array}$ & $\begin{array}{l}\text { Agendas, } \\
\text { maus } \\
\text { pensamentos, } \\
\text { conjecturas, } \\
\text { diários } \\
\text { ítimos. }\end{array}$ & $\begin{array}{l}\text { Cartas, } \\
\text { respostas a } \\
\text { questionários, } \\
\text { a testes proje- } \\
\text { tivos e } \\
\text { trabalhos } \\
\text { escolares. }\end{array}$ & $\begin{array}{l}\text { Ordens de serviço } \\
\text { numa empresa, } \\
\text { todas as } \\
\text { comunicações } \\
\text { escritas trocadas } \\
\text { dentro de um grupo. }\end{array}$ & $\begin{array}{l}\text { Jornais, livros, } \\
\text { anúncios } \\
\text { publicitários, } \\
\text { cartazes, lite- } \\
\text { ratura,textos } \\
\text { jurídicos, } \\
\text { panfletos. }\end{array}$ \\
\hline Oral & $\begin{array}{l}\text { Delírio do } \\
\text { doente } \\
\text { mental, } \\
\text { sonhos. }\end{array}$ & $\begin{array}{l}\text { Entrevistas e } \\
\text { conversas de } \\
\text { qualquer } \\
\text { espécie. }\end{array}$ & $\begin{array}{l}\text { Discussões, } \\
\text { entrevistas, } \\
\text { conversas de grupo } \\
\text { de qualquer } \\
\text { natureza. }\end{array}$ & $\begin{array}{l}\text { Exposições, } \\
\text { discursos, rádio, } \\
\text { televisão, } \\
\text { cinema, } \\
\text { publicidade, } \\
\text { discos. }\end{array}$ \\
\hline $\begin{array}{l}\text { ICÔNICO } \\
\text { (sinais, } \\
\text { grafismos, } \\
\text { imagens, } \\
\text { fotografias, } \\
\text { filmes,etc.) }\end{array}$ & $\begin{array}{l}\text { Rabiscos } \\
\text { mais } \\
\text { ou menos } \\
\text { automáticos, } \\
\text { grafites e } \\
\text { sonhos. }\end{array}$ & $\begin{array}{l}\text { Respostas aos } \\
\text { testes proje- } \\
\text { tivos, comu- } \\
\text { nicação entre } \\
\text { duas pessoas } \\
\text { por meio de } \\
\text { imagem. }\end{array}$ & $\begin{array}{l}\text { Toda comunicação } \\
\text { icônica num pe- } \\
\text { queno grupo (ex.: } \\
\text { símbolos icônicos } \\
\text { numa sociedade se- } \\
\text { creta, numa } \\
\text { casta.....). }\end{array}$ & $\begin{array}{l}\text { Sinais de } \\
\text { trânsito, } \\
\text { cinema, } \\
\text { publicidade, } \\
\text { pintura, cartazes, } \\
\text { televisão. }\end{array}$ \\
\hline $\begin{array}{l}\text { OUTROS } \\
\text { CÓDIGOS } \\
\text { SEMIÓTICOS } \\
\text { (i. e., tudo o que, } \\
\text { não sendo } \\
\text { linguístico, pode } \\
\text { ser portador de } \\
\text { significados, ex.: } \\
\text { música, código } \\
\text { olfativo, objetos } \\
\text { diversos, } \\
\text { comporta- } \\
\text { mentos, espaço, } \\
\text { tempo, } \\
\text { sinais patoló- } \\
\text { gicos etc.) }\end{array}$ & $\begin{array}{l}\text { Manifestações } \\
\text { histéricas da } \\
\text { doença } \\
\text { mental, pos- } \\
\text { turas, gestos, } \\
\text { tiques, dança, } \\
\text { coleções de } \\
\text { objetos. }\end{array}$ & $\begin{array}{l}\text { Comunicação n } \\
\text { a outrem (postu } \\
\text { espacial, sinais } \\
\text { manifestações } \\
\text { cotidianos, vest } \\
\text { etc.), comporta } \\
\text { como os ritos e }\end{array}$ & $\begin{array}{l}\text { o verbal com destino } \\
\text { a, gestos, distância } \\
\text { lfativos, } \\
\text { nocionais, objetos } \\
\text { ário, alojamento } \\
\text { entos diversos, tais } \\
\text { s regras de cortesia. }\end{array}$ & $\begin{array}{l}\text { Meio físico e } \\
\text { simbólico: } \\
\text { sinalização } \\
\text { urbana, } \\
\text { monumentos, } \\
\text { arte etc.; mitos, } \\
\text { estereótipos, } \\
\text { instituições, } \\
\text { elementos de } \\
\text { cultura. }\end{array}$ \\
\hline
\end{tabular}

FONTE: BARDIN; 2007, p. 36. 
O presente estudo adotou a análise do conteúdo linguístico oral entre duas pessoas por meio da entrevista em profundidade. A fim de garantir a acurácia da análise do conteúdo das entrevistas, estas foram transcritas para uma planilha na qual foram inseridas as falas organizadas segundo categorias classificadas de acordo com as ferramentas de comunicação e as respectivas métricas levantadas na etapa de fundamentação teórica.

A sistematização das informações coletadas nas entrevistas permitiu a etapa posterior de análise do conteúdo do discurso dos entrevistados: a exploração do material com categorização das respostas. A fim de lidar com a diversidade de expressões e jargões adotados pelos entrevistados, alguns dos quais particulares ao vocabulário de algumas instituições, com base no conteúdo apurado na fundamentação teórica, foram interpretados alguns discursos, identificando similaridades na fala dos entrevistados. Dessa forma, expressões como "relacionamento com clientes", "CRM" e "database", foram tratadas e consideradas como tendo o mesmo significado.

A análise das ferramentas de comunicação e métricas foi feita tanto isoladamente para cada entrevistado quanto para o conjunto das entrevistas que, nesse caso foram comparadas entre si. Esta análise conduziu à terceira etapa da análise do conteúdo, ou seja, o tratamento dos resultados, as inferências e a interpretação das informações coletadas e viabilizou a identificação das ações, das métricas mais significativas, de restrições, desafios e fatores que permitem maior efetividade na adoção das métricas de avaliação dos resultados de comunicação.

A seguir será descrita a pesquisa de campo - coleta e análise dos dados. 


\section{PESQUISA DE CAMPO}

\subsection{Coleta dos dados}

O primeiro passo para o procedimento da coleta dos dados foi o contato telefônico ou envio de e-mail (Anexo 2) explicando os objetivos da pesquisa. Nos casos de contatos feitos com pessoas desconhecidas, indicadas por amigos ou conhecidos, a pesquisadora teve o cuidado de utilizar seu e-mail da USP para qualificar sua relação com a instituição. Os e-mails foram seguidos de contatos telefônicos para acelerar o processo de marcação das entrevistas pessoais. Todos os contatos, o agendamento das entrevistas e sua realização foram conduzidos pela pesquisadora.

Conforme mencionado, as entrevistas foram realizadas nos meses de outubro e novembro de 2011 por meio de entrevistas em profundidade com profissionais envolvidos nas decisões de comunicação.

Foram entrevistados nove profissionais relacionados a sete bancos. Em duas instituições foram conduzidas duas entrevistas. A fim de obter as informações necessárias a este estudo, foi essencial o compromisso de sigilo quanto aos bancos e nomes dos entrevistados. Por isso, não será possível identificar os respondentes, nem atribuir suas respostas aos bancos que representam. Outro cuidado para garantir o sigilo foi a omissão dos nomes dos bancos, de títulos de eventos patrocinados pelos bancos, dos canais de atendimento e qualquer outra informação que pudesse evidenciar o banco representado pelos entrevistados.

Para garantir que o entrevistado estivesse apto a responder sobre as decisões de investimentos em comunicação, havia uma pergunta filtro sobre o envolvimento do entrevistado com decisões de comunicação de marketing. Todos estavam envolvidos, mas em diferentes graus. Alguns tinham controle total das decisões, outros dependiam da apreciação de um comitê, de superiores ou até mesmo de pares.

O Quadro10 indica os dados referenciais das entrevistas conduzidas junto aos executivos e especialistas dos sete bancos. As instituições serão denominadas: Banco 1, 
Banco 2, e assim sucessivamente. O quadro está organizado segundo a ordem cronológica de realização das entrevistas.

São revelados os cargos, ou sua qualificação, nos casos dos especialistas, o envolvimento e objeto da comunicação de marketing em que o entrevistado atua produto ou institucional -, o dia da entrevista, o tempo de duração da entrevista e se esta foi realizada por telefone, Skype ou pessoalmente. A entrevista 7, realizada com profissonal do Banco B2 foi invalidada por desistência do entrevistado.

A diversidade de tempo de duração das entrevistas ocorreu por diferentes motivos. Houve casos em que a empresa não aplicava métricas específicas, avaliava os resultados com base em uma única métrica como valor da marca, ou ainda, situações em que o entrevistado não estava disposto a compartilhar informações.

\section{Quadro 10 - Dados referenciais das entrevistas}

\begin{tabular}{|c|c|c|c|c|c|c|}
\hline Entrevista & Banco & Cargo & $\begin{array}{l}\text { Envolvimento com } \\
\text { comunicação }\end{array}$ & Data & $\begin{array}{c}\text { Meio de } \\
\text { entrevista }\end{array}$ & Tempo \\
\hline E1 & B1 & Diretor & $\begin{array}{l}\text { Total. Decide, planeja e } \\
\text { responde. }\end{array}$ & $07 / 10 / 2011$ & Telefone & $\begin{array}{l}10 \\
\text { minutos }\end{array}$ \\
\hline E2 & B1 & Analista & $\begin{array}{l}\text { Comunicação Middle } \\
\text { Market com foco em } \\
\text { relacionamento }\end{array}$ & $07 / 10 / 2011$ & Telefone & $\begin{array}{l}14 \\
\text { minutos }\end{array}$ \\
\hline E3 & B2 & Diretor & $\begin{array}{l}\text { Alto envolvimento } \\
\text { compartilhado com } \\
\text { outros profissionais }\end{array}$ & $11 / 10 / 2011$ & Pessoal & $\begin{array}{c}20 \\
\text { minutos }\end{array}$ \\
\hline E4 & B3 & Gerente & $\begin{array}{l}\text { Envolvimento total nas } \\
\text { decisões de marketing } \\
\text { direto e CRM }\end{array}$ & $28 / 10 / 2011$ & Pessoal & $\begin{array}{l}1 \text { hora e } \\
\text { meia }\end{array}$ \\
\hline E5 & B4 & Gerente & $\begin{array}{l}\text { Total produto e } \\
\text { institucional }\end{array}$ & $03 / 11 / 2011$ & Pessoal & $\begin{array}{c}20 \\
\text { minutos }\end{array}$ \\
\hline E6 & B5 & Diretor & $\begin{array}{l}\text { Total de produtos e } \\
\text { institucional }\end{array}$ & 04/11/2011 & Pessoal & $\begin{array}{c}40 \\
\text { minutos }\end{array}$ \\
\hline E7 & B2 & Analista & $\begin{array}{l}\text { Experiência como um } \\
\text { todo para construção de } \\
\text { imagem }\end{array}$ & $04 / 11 / 2011$ & Telefone & $\begin{array}{c}4 \\
\text { minutos }\end{array}$ \\
\hline E8 & B2 & $\mathrm{VP}$ & Total & $09 / 11 / 2011$ & Skype & $\begin{array}{c}1 \text { hora e } \\
\text { meia }\end{array}$ \\
\hline E9 & B6 & Diretor & $\begin{array}{l}\text { Grande no institucional } \\
\text { e de produto }\end{array}$ & $14 / 11 / 2011$ & Pessoal & $\begin{array}{c}50 \\
\text { minutos }\end{array}$ \\
\hline E10 & B7 & $\begin{array}{l}\text { Consultor } \\
\text { de } \\
\text { marketing }\end{array}$ & $\begin{array}{l}\text { Total em marketing } \\
\text { direto PF e PJ, exceto } \\
\text { institucional }\end{array}$ & 23/11/2011 & Telefone & $\begin{array}{c}20 \\
\text { minutos }\end{array}$ \\
\hline
\end{tabular}

FONTE: Elaborado pela autora 


\subsection{Análise dos dados}

O primeiro passo da análise dos dados foi a pré-análise que, segundo Bardin (2007) consiste na preparação do material levantado por meio da transcrição das entrevistas Não foram considerados na transcrição, o início e o final da entrevista.

Os trechos considerados na etapa de preparação foram categorizados conforme os temas que nortearam a fundamentação teórica da pesquisa e estão descritos a seguir:

i) ações de comunicação offline mais significativas (COF)

ii) ações de comunicação online mais significativas (CON)

iii) métricas de avaliação das ações de comunicação offline mais adotadas (MCOF)

iv) métricas de avaliação das ações de comunicação online mais adotadas (MCON)

v) comparação entre as métricas (CM)

Após a classificação das categorias, a etapa seguinte foi a sistematização das informações coletadas nas entrevistas que permitiu a etapa de tratamento dos resultados, as inferências e a interpretação das informações coletadas.

Como mencionado, o critério adotado para a categorização foi o semântico, tendo como referência o tema das categorias de ferramentas de comunicação e as métricas de avaliação dessas ferramentas. O tratamento dos resultados seguiu a categorização da etapa de pré-análise e permitiu fazer inferências e interpretações das informações levantadas nas entrevistas.

Na sequência, foi avaliada a frequência de menção das categorias, identificadas por códigos para cada um dos sete bancos. As informações levantadas variaram conforme fatores que, segundo a pesquisadora, envolveram interesse do entrevistado, diversidade e intensidade de investimentos em comunicação e adoção das métricas de avaliação dos resultados aplicação das métricas.

No caso de dois bancos foram entrevistados dois profissionais. Para efeito da análise de conteúdo, considerou-se que cada dupla representava uma instituição. Por isso, na etapa de análise das informações coletadas, foram considerados cada um dos sete bancos 
isoladamente e não os nove entrevistados. Caso contrário, a contagem total para cada ferramenta de comunicação excederia o número de instituições contidas no estudo.

A contagem foi simples, uma vez que quantidade de entrevistas, o tempo de sua duração e a quantidade de informações levantadas para cada ferramenta de comunicação foram inferiores a cem e, portanto, não seria possível o cálculo de percentuais.

Para cumprir o compromisso de confidencialidade das informações fornecidas pelos entrevistados, não será apresentada a resposta do representante de cada banco, mas os resultados totais da contagem das respostas, garantindo-se dessa forma que não será possível identificar as estratégias de comunicação nem as métricas de avaliação dos resultados dos investimentos em comunicação adotadas por cada banco.

\subsubsection{Ferramentas de comunicação offline e online mais significativas}

A Tabela 4 apresenta as categorias, as respectivas ferramentas de comunicação offline e online que representam e o número de vezes em que foram citados. As ferramentas mencionadas pelos entrevistados estão organizadas em ordem decrescente de citações.

Tabela 4 - Categorias consideradas na análise de conteúdo e ferramentas do mix de comunicação online e offline

\begin{tabular}{|c|c|}
\hline $\begin{array}{l}\text { Categorias consideradas na análise de conteúdo e } \\
\text { ferramentas de comunicação offline e online }\end{array}$ & Citações \\
\hline Propaganda offline e online - COF1 e CON1 & 7 \\
\hline Marketing de relacionamento - $\mathrm{COF} 9$ & 7 \\
\hline Patrocínio - COF3 & 4 \\
\hline Marketing direto $^{2}-$ COF5 & 4 \\
\hline Mídias sociais ${ }^{3}-\mathrm{CON} 3$ & 4 \\
\hline Venda Pessoal - COF6 & 2 \\
\hline Relações públicas e publicidade - COF2 & 2 \\
\hline Advertainment online - CON2 & 1 \\
\hline Promoção de vendas - COF4 & 0 \\
\hline Product placement-COF7 & 0 \\
\hline
\end{tabular}




\begin{tabular}{|c|c|}
\hline Merchandising - COF8 & 0 \\
\hline Evento técnico - COF10 & 0 \\
\hline Advertainment - COF12 & 0 \\
\hline
\end{tabular}

${ }^{1}$ Compreende propaganda veiculada em mídias offline e mídias online - tradicional, como portais -, redes sociais e internet banking.

${ }^{2}$ Envolve ATM e canais tradicionais como telefone e correio.

${ }^{3}$ Inclui Propaganda online, Redes sociais, Marketing viral e Buzz marketing.

COF - Comunicação offline

CON - Comunicação online

FONTE: Elaborado pela autora

Os dados apresentados na Tabela 4 confirmam levantamento feito no capítulo 2 e sumarizado no Quadro 8, que apontou que as ferramentas mais adotadas pelas instituições bancárias são: propaganda, relações públicas, publicidade, patrocínio, marketing direto, venda pessoal, marketing digital, marketing de relacionamento e redes sociais.

A partir da Tabela 4 é possível ordenar as mais significativas ferramentas de comunicação offline e online. Algumas ações de comunicação não foram citadas pelos entrevistados e as mencionadas foram indicadas por sete, quatro, dois ou um representante dos bancos da amostra. Tendo em vista o objetivo de propor um modelo de adoção de métricas de avaliação dos resultados das ações de comunicação offline e online apontadas pela amostra como as mais importantes, foram analisadas as ferramentas citadas por, ao menos quatro bancos entrevistados, ou seja: propaganda offline e online; marketing de relacionamento, patrocínio, marketing direto e mídias sociais.

Em alguns casos, quando mencionados pelos respondentes, serão revelados os motivos ou objetivos buscados com a adoção das ferramentas de comunicação. Não foi possível levantar estas informações em todas as entrevistas.

\subsubsection{Ações de propaganda offline e online}

Todos os bancos entrevistados mencionaram que a propaganda era uma das ações de comunicação mais importantes e toda a amostra declarou investir especificamente em 
propaganda na mídia TV e em revistas. Além destas mídias, seis bancos citaram jornal, três indicaram propaganda em rádio e um destacou a importância da propaganda nos canais de atendimento do setor bancário, mais particularmente no internet banking e ATM. Somente um entrevistado declarou desenvolver ação de propaganda online.

Por tratar-se de um serviço de massa, alguns bancos possuem milhões de correntistas, sendo esperado que esta ferramenta tivesse destaque no mix de comunicação:

O calendário de comunicações offline, é praticamente formado de, pelo menos (...)flights no ano, que acabam tomando um calendário horizontal (...) o ano todo (...) uma presença forte no cabo e a gente complementa com outras mídias como revistas, como rádio (...)

(..) olha, considerando inclusive o próprio contexto de banco, perfeito, aí você está falando em atingir milhões e milhões de pessoas, que um banco tem 10 a 20 milhões de clientes, como correntistas, por conta disto, televisão é muito importante (...)

No que tange ao aspecto de mídia adotada nas ações de propaganda, a amostra atribuiu grande importância à TV, sendo mencionado que,

(...) geralmente pessoa física precisa de comunicação mais para fora, pessoa jurídica precisa de comunicação mais para dentro.

(...) é a mídia mais importante, por duas razões, porque é a que tem maior alcance e a que tem menor custo por mil.

(...) num banco com 50 milhões, 40 milhões de correntistas, é quase mais barato falar com a base de cliente pela televisão.

Em relação à TV, as menções incluíram TV aberta e a cabo:

(..) uma presença forte no cabo e aí a gente complementa com outras mídias como revistas, como rádio (...).

(...) então a gente elegeu TV a cabo (...).

Além das mídias tradicionais - TV, revista, jornal, rádio, internet, etc. -, o setor estudado adota mídias específicas como ATM e internet banking para a veiculação de propaganda. Estas últimas mídias oferecem a vantagem de serem usadas com regularidade pelos correntistas para acompanhar e movimentar suas contas correntes pagamentos, transferências e aplicações. 
A mídia internet foi citada por todos os entrevistados para a veiculação de propaganda. Foram indicados veículos tradicionais como portais, criação de hotsites, busca de palavras, internet banking e e-mail marketing.

Como veículos online menos tradicionais, foram citadas as redes sociais - Facebook, YouTube e Twitter e blogs.

A propaganda online está alinhada com a campanha offline e por isso, a propaganda offline e online foram consideradas em conjunto. A online suporta no mundo virtual a campanha offline:

(...) A gente trabalha mais ou menos na mesma linha do offline, tudo tem desmembramento online e offline.

Somente um banco mencionou esforços de desenvolvimento de campanhas com filmes exclusivos para a internet.

(...) essa é outra mídia que toda campanha nossa agora a gente faz vídeo deste tipo pro YouTube (...)

Outro aspecto citado para justificar o uso da TV é a relação entre propaganda e marca, conforme relatado por um entrevistado em dois momentos distintos da entrevista:

O que a gente vê é que a correlação entre investimento em televisão e o aumento da marca é de $90 \%$. Saiu do ar, caiu, voltou, subiu.

Posso dizer quanto alcanço com $\mathrm{R} \$ 80$ milhões em televisão, eu consigo hoje com esta pesquisa de marca saber até o impacto de ficar dentro ou ficar fora, o impacto dentro da marca, isso eu consigo. Eu sei o que sobe e o que desce se eu ficar fora do ar.

Em relação ao conteúdo da propaganda, somente um entrevistado mencionou a importância do entendimento da mensagem na avaliação da efetividade da propaganda.

Compreensão de mensagem é super importante. (...) (tem que avaliar se) a compreensão da mensagem foi tal qual eu imaginava (...)

Conforme relato de dois entrevistados, as justificativas apontadas para a escolha da TV foram habilidade e efetividade desta mídia para atingir uma grande quantidade de clientes B2C: 
(...) falando em atingir milhões e milhões de pessoas, televisão é muito importante, por duas razões: porque tem maior alcance e menor custo por mil.

A gente tem principalmente dois grandes estudos para avaliação de filmes de TV, um deles é pré-teste e pós-teste de comercial, hoje no banco não se coloca nenhuma campanha no ar sem ser pré-testada, tem que fazer sempre o pré-teste qualitativo quando for um novo conceito ou posicionamento, e outro quando não for um novo conceito (...)

Os motivos mais citados para investimentos em propaganda pelos entrevistados eram nesta ordem:

i) campanhas institucionais - sete bancos;

ii) produtos - seis bancos;

iii) posicionamento - três bancos;

Dentre as ações de propaganda citadas pelos entrevistados, figuraram duas menções a patrocínio de TV, tais como cota de um programa ou competição esportiva que, Belch e Belch (2008, p. 349) classificam como propaganda. Por isso, não foram consideradas entre as ações de patrocínio de evento.

Sobre a decisão de adoção de propaganda, um entrevistado destacou a importância que as agências de publicidade exercem sobre esta decisão de comunicação e como desfavorecem a avaliação dos resultados:

As agências de comunicação muitas vezes não contribuem para isso, elas atrapalham, pois elas são premiadas mais pela criatividade e insights da campanha, do que pela aderência estratégica da campanha com o que o cliente propôs. Até porque você vai olhar os prêmios de Cannes e outros prêmios locais e muitas vezes quem está julgando não sabe, nem avalia em profundidade qual era a estratégia do cliente, qual o problema. A campanha está maravilhosa, botou todo mundo cantando o jingle, o mote pegou. Isso é muito legal, mas muitas vezes se for olhar a maiora das agências elas são muito melhores na criação e mídia do que no planejamento.

Elas são remuneradas pelo quanto de mídia, algumas coisas você pode colocar um fee ou não, tem legislações específicas que defendem as agências sobre isso. Fica um conflito de interesse, porque elas querem veicular aonde dá mais dinheiro para elas. Até porque muitos dos prêmios são dados para os profissionais de mídias. Vemos que os prêmios são para os profissionais de criação e mídias. Quem dá esses prêmios, por acaso, são os próprios veículos de comunicação. Fica um conflito desgraçado.

Essa avaliação contraria a posição de Conceição (2011, p.10), de que as agências publicitárias vêm acompanhando a tendência de foco em avaliação dos resultados e que 
o profissional de mídia, responsável pelas decisões de mídia de campanhas publicitárias, deve estar atento às novas métricas para avaliar o desempenho das mídias e poder entregar resultados ao cliente.

A partir do exposto, é possível constatar que propaganda é uma ação essencial para a imagem institucional das instituições e divulgação de produtos dos bancos, tendo como público-alvo a massa. Conclui-se a importância que as agências de publicidade exerce nas decisões dessa natureza, sobretudo na escolha da mídia, em função da forma com que são remuneradas. Dentre as mídias, a de maior destaque é a TV.

\subsubsection{Ações de marketing de relacionamento}

Todos os bancos entrevistados mencionaram a importância de ações de relacionamento com sua base de clientes ou CRM, como denominado por alguns entrevistados.

Os principais motivos para lançar mão desta ferramenta são: alavancar vendas junto à base de clientes, fidelizar clientes, evitar perdas, avaliar retorno dos clientes, atrair prospects ou mesmo avaliar o retorno de campanhas online. O marketing de relacionamento é aplicado tanto para clientes PJ quanto PF.

A menção de relacionamento como ação de comunicação foi espontânea, pois durante a entrevista não foram reveladas as possíveis ferramentas do mix de comunicação. Portanto, o fato de todos os entrevistados terem citado marketing de relacionamento como ação de comunicação reforça a proposição de Ogden e Crescitelli (2007, p. 31) de que esta ação seja inserida no conjunto das ferramentas de comunicação. Para estes autores, a comunicação é inerente ao processo de relacionamento, e é fundamental para a criação e manutenção de um canal de comunicação com clientes, pois sem a comunicação não pode haver marketing de relacionamento.

No entanto, os resultados encontrados indicam que ao invés de classificar essa ferramenta como complementar (OGDEN; CRESCITELLI, 2007), os entrevistados consideram que esta ferramenta exerce um papel de uma ferramenta tradicional, sendo 
fundamental ao plano de comunicação dos bancos representados na amostra entrevistada.

A importância das ações de relacionamento no contexto do negócio é grande, conforme relato de dois entrevistados:

(...) a base do nosso marketing é marketing de relacionamento, então estas mídias, essa comunicação de massa ela é quase um apoio para todo o foco que eu tenho que é relacionamento (...).

(...) uma característica essencial é o relacionamento com o cliente (...) essa relação mais próxima com ele. Eu acho que o resumo é: fundamental essa coisa de você entender (o cliente) mesmo, para você entender e oferecer para ele a solução mais próxima ou personalizada do que ele está precisando realmente.

A concretização e sustentação desta ferramenta de comunicação são possíveis, em grande parte, pela quantidade de informação disponível sobre seus clientes:

Porque de fato, tem muita informação - valores que transitam na conta corrente, cartão de crédito, corretoras, financiamentos, dos clientes que trabalham com vários produtos, acaba tendo muita informação.

De acordo com três entrevistados, administrar a grande quantidade de informações é possível graças à gestão do banco de dados ou CRM.

Eu vejo que o CRM me ajuda muito, é uma ferramenta realmente fundamental para gerar informação estratégica. Você consegue extrair daquela ferramenta, informações pra criar soluções novas, criar ações novas de marketing, indo até para a força de venda.

O CRM hoje pra gente é uma ferramenta que gera histórico, a gente tem todo tipo de contato que o gerente do banco teve com o cliente, seja uma mala direta que foi enviada, seja outro tipo de comunicado, seja uma visita que foi realizada (...) um evento que este cliente participou (...).

(...) como você tem diferentes heads, cuidando de partes desse negócio, eles não se falam e aí as decisões não são conectadas. Mas geralmente, é assim: você tem alguém que é responsável pelo CRM, marketing de relacionamento, geralmente a retenção está numa área específica.

Além da base de dados, os gerentes representam importante papel no relacionamento do banco com seus clientes.

(...) a gente preza pelo relacionamento nas visitas comerciais dos gerentes comerciais quando vão até o cliente para apresentar como o banco atua quais os produtos que oferece, as condições etc (...) 
Dentre as ações de marketing de relacionamento, foi incluído o que dois entrevistados de distintos bancos denominaram "evento de relacionamento". Essa modalidade poderia ser classificada como "evento patrocinado", mas optou-se por incluí-la em relacionamento devido à ênfase dada pelos entrevistados à finalidade de relacionamento e também pelo fato de os entrevistados descreverem os eventos como algo restrito a um número pequeno de clientes e terem elevado nível de customização.

Outra possibilidade de classificação seria a de "evento técnico" que, no entanto, com base na fundamentação teórica, também foi descartada. Para Ogden e Crescitelli (2007, p.30), esta modalidade de ação de comunicação inclui feiras, congressos, seminários, shows, dentre outras possibilidades. Para Hersch (2007) o evento técnico propicia a oportunidade de encontro de pessoas numa situação favorável ao fechamento de negócios.

Caso "evento de relacionamento" não tivesse sido classificado como uma modalidade de marketing de relacionamento, a contagem das instituições que utilizam ações de marketing de relacionamento seria de seis e não sete bancos.

A seguir menções dos dois entrevistados sobre a adoção de evento de relacionamento:

(...) referente a esta ferramenta específica, para evento, tem todo histórico, tanto de prospecção, conversão para cliente, enfim, empresas que participaram destes eventos de relacionamento na nossa ferramenta de CRM.

(...) é evento de relacionamento. Então aqui no caso os eventos servem como uma maneira simpática uma maneira agradável e eficiente para mostrar o trabalho do banco, o produto que ele oferece e mostrar um pouco da equipe do banco também, como atua etc.

Quanto ao objetivo e tipo de evento oferecido para prospects e clientes, os mesmos dois entrevistados mencionaram:

O CRM hoje pra gente é uma ferramenta que gera histórico, a gente tem todo tipo de contato que o gerente do banco teve com o cliente, seja uma mala direta que foi enviada, seja outro tipo de comunicado, seja uma visita que foi realizada, (...) um evento que este cliente participou (...). Conseguimos ter um cadastro e saber, se esta pessoa gosta de vinho, a gente vai fazer uma evento que tem degustação de vinho, a gente pode convidá-lo para participar e então fazer ações mais direcionadas, até para isso serve o CRM.

(...) Então hoje esse processo do evento é uma das ferramentas que a gente usa, que a gente chama de evento de relacionamento, a gente costuma fazer também eventos para prospects, que não são ainda clientes do banco. 
Num negócio com um longo ciclo de consumo, como o de serviços bancários, o consumidor não está disposto a trocar de provedor com frequência. Por isso, é fundamental o investimento em relacionamento. Esta ação é sustentada por três dimensões fundamentais, que são operadas de forma interconectada: banco de dados de clientes, marketing direto offline e online e relacionamento do gerente.

\subsubsection{Ações de patrocínio de evento}

Quatro, dentre os sete representantes dos bancos estudados disseram que patrocínio era uma ferramenta importante em seu marketing mix. Portanto, as entrevistas comprovaram a relevância da ferramenta de patrocínio de eventos, conforme indicado na etapa de levantamento bibliográfica.

Para Shimp (2002, p. 48), o patrocínio “(...) é uma forma de promoção de marca em que esta é associada a um evento atlético, de lazer, cultural social ou outro tipo de atividade de interesse público". Em relação ao tipo de evento, os entrevistados revelaram que patrocínios de eventos esportivos e culturais eram as modalidades mais importantes dentre as possíveis ações desta natureza.

No que tange ao motivo, as razões apontadas pelos entrevistados para a adoção de patrocínio são a facilidade de medir seu impacto sobre vendas e sobre a satisfação de clientes, conforme mencionado por um entrevistado:

Na parte de patrocínio (...), nós também temos a taxa de retorno dos convites dos clientes, nível de satisfação dos clientes quando são agraciados com convite para assistir a algum show, espetáculo, margem de contribuição desses clientes também, ou seja, se o relacionamento dele com o banco aumenta ou não, então a gente faz esta verificação dos eventos (...).

De acordo com outro entrevistado, além de vendas e satisfação, o estreitamento de relacionamento com clientes e a mídia espontânea são benefícios do patrocínio,

(...) Outro aspecto é a mídia espontânea gerada, a gente tem uma assessoria de imprensa que contrata uma empresa que mede a centimetragem gerada com a marca e quanto isso vale em dinheiro. Outro aspecto que a gente faz, todos estes eventos têm um espaço exclusivo para relacionamento com clientes (...). 
Dentre os eventos citados, foram mencionados desde os eventos voltados para a grande massa, até eventos para pequenos públicos. Os públicos-alvo destes eventos variavam de não clientes, passando por prospects até clientes de maior valor para as instituições entrevistadas.

A mensuração era possível por meio de database que permitia o controle de utilização de convites enviados para prospect e clientes de maior importância. Após a avaliação do uso dos convites era feito o monitoramento do comportamento dos participantes dos eventos quanto à contratação de serviços e satisfação com a instituição patrocinadora.

\subsubsection{Ações de marketing direto}

Dados da Abemd relativos a 2009 indicam que, 25\% do que foi movimentado em marketing direto no Brasil, foi proveniente do setor bancário. Por isso, não surpreende esta ser uma das três ações mais importantes de comunicação apontadas pelos entrevistados.

Alguns entrevistados do setor bancário confirmaram características atribuídas às ações de marketing direto na fundamentação teórica, como mensurabilidade e precisão (SHIMP, 2002, p.328):

(...) marketing direto é o mais simples de todos, então todas as ações de cross-sell de produto, up-sell de produto ou de ativação, cartão que o cliente não usa e ele passa a usar, esses eu consigo medir diretamente o resultado, quanto investi, qual a rentabilidade do produto comprado ou o incremento de ativação realizado e eu consigo medir exatamente o ROI daquela ação.

Em relação à mala direta aí é bem mais simples de medir, porque como a gente está trabalhando com a nossa própria base, o que a gente faz é cortar uma base que sei que vou falar para vender seguro. A gente pega a base, que foi quem foi impactado, pega uma base que não foi impactada, que a gente chama de grupo de controle e a gente mede, quanto que as duas se movimentaram. A diferença percentual de uma para a outra é o resultado da mala direta. É o que que aquilo ali, incentivou o cliente a comprar.

Em relação às iniciativas offline e online, a exemplo da propaganda, há esforços de integração entre as ações de marketing direto offline e online:

A gente trabalha mais ou menos na mesma linha do offline, tudo tem desmembramento online e offline. Mala direta faz mais ou menos na mesma linha do offline. Quando faz campanha offline de seguro faz online e é capaz de saber quantos cliques teve naquela peça. O cliente faz login e consegue saber quantos clientes viram uma peça e pra e-mail 
marketing faz a mesma medição de mala direta e saber quem foi impactado quem mexeu e quem não mexeu e consegue saber o que aquele e-mail marketing deu de resultado.

No que tange ao retorno das ações de marketing direto, o momento do ciclo de relacionamento com o cliente - prospect, novo cliente, etc - influencia os resultados alcançados:

(...) outra coisa também que influencia o retorno, é o momento de relacionamento daquele cliente, ou ele é um cliente novo, ou ele é um cliente legado vamos falar assim, tá lá no dia a dia, ou, ele é um cliente em processo de retenção, ele ainda não saiu, ele está migrando para sair. Os retornos são muito diferentes.

De acordo com um entrevistado, um dos objetivos das ações de marketing direto é gerar uma ação - call to action - pelo cliente, sendo, portanto uma das formas de avaliação desta ação.

(...) se eu fizer qualquer ação sem um call to action, o retorno geralmente é mais baixo do que uma (ação) com call to action. Por quê? Porque as pessoas são curiosas, isto é um fato. Segundo, se você for falar de alguma coisa que tenha preço, só vale a pena você falar se assim, as pessoas, sabem, se elas têm uma base para pegar aquela mala direta e falar assim: “- Meu, isso está barato", porque senão, não vale nada.

Uma boa gestão do banco de dados de clientes e prospects é essencial para a efetividade das ações de marketing direto.

Intrinsecamente ligado ao marketing de relacionamento, o marketing direto representa uma das bases de sustentação do negócio do setor bancário e exerce papel fundamental na comunicação do setor estudado.

\subsubsection{Ações nas mídias sociais}

O entendimento da distinção entre ações de comunicação offline e online não foi homogêneo em toda a amostra. Dois entrevistados questionaram o significado destes termos e foi necessário que a entrevistadora esclarecesse que online referia-se a ações de comunicação na internet e offline às demais ações.

A relevância da internet na atualidade impulsiona a amostra estudada a atingir clientes, prospects e stakeholders, por meio de diferentes iniciativas. Apesar da importância 
atribuída à dimensão online, somente um entrevistado indicou a formação de uma equipe própria montada exclusivamente para monitorar e acompanhar o comportamento do público em geral nas redes, e não somente os clientes do banco.

Somente um banco citou iniciativas de propagação de uso da mídia social com seus funcionários, em linha com a proposta de Gupta et al (2011, p. 4-6) de que as organizações aprendam como a mídia social funciona por meio de iniciativas que propaguem sua adoção e gerem a imersão de seus funcionários nesta mídia.

Conforme levantamento na internet, todos os bancos entrevistados estão presentes nas redes sociais e dois dedicam esforços a investir em blogs. No entanto, somente quatro entrevistados atribuíram importância à presença das instituições nas redes sociais. Destes, três disseram monitorar o comportamento do internauta nas redes sociais ou estar engajados reagindo e interagindo às manifestações na rede, em particular no Facebook e Twitter.

Os quatro bancos atribuíram importância a ações nas redes sociais. A partir do conteúdo levantado na fundamentação teórica e da descrição das ações neste ambiente, consideraram-se as ferramentas de buzz marketing e marketing viral nas ações nas redes sociais, mídia com elevada capacidade de geração de um viral e de buzz.

(...) então o banco tomou a decisão de montar um grupo para monitorar e, principalmente para interagir com estes clientes quando eles estão manifestando problemas.

Nenhum entrevistado demonstrou conhecer ou aplicar o conceito de CRV ou valor das recomendações que seus clientes podem gerar (KUMAR et al, 2007, p. 143-144).

A partir da combinação do conteúdo extraído das entrevistas sobre ações na internet com as definições de Kumar et al (2007, p. 143-144), Gupta et al (2011, p. 3-5) e Wilson et al (2011, p. 23), adotou-se o termo mídias sociais para definir o conjunto das ações de comunicação realizadas na internet - redes sociais, blogs e demais comunidades virtuais. Excluíram-se dessa generalização as ações de propaganda e marketing direto online. 
Somente um banco mencionou adotar advertainment online, mas não atribuiu muita importância para esta ação de comunicação:

(...) uma caça ao tesouro no Facebook, as pessoas tinham que ir buscando, pegavam dica e iam procurando (...), então a gente está fazendo todo um trabalho muito legal

Segundo as classificações sobre mídias sociais indicadas nas entrevistas, estas envolvem ações que incluem esforços para acompanhar o comportamento dos consumidores no ambiente online, identificar potenciais advogados ou promotores e detratores e interagir com os clientes e, por último, procurar e gerar conteúdo relevante para os outros e para seu negócio. Ação de advertainment online foi classificada como pertencente à categoria de geração de conteúdo.

Apenas um respondente mencionou identificar os detratores de sua marca. $\mathrm{O}$ mesmo executivo indicou esforços no sentido de criar grupos de advogados da marca e da empresa ser agregador de conteúdo na mídia social, conforme proposta de Gupta et al (2011, p. 4).

(...) o banco adotou como postura aqui interagir com todos. Em qualquer reclamação, não importa o valor, qualquer manifestação, reclamação de qualquer coisa (...).

A Tabela 5 ilustra as iniciativas dos bancos que atribuíram importância a inciativas nas mídias sociais.

Tabela 5 - Atuação dos bancos nas mídias sociais

\begin{tabular}{|c|c|}
\hline Ações nas mídias sociais & Citações \\
\hline Presença nas redes $^{1}$ & 4 \\
\hline Parcerias com blogueiros & 2 \\
\hline Agregador de conteúdo & 1 \\
\hline Identificar detratores & 1 \\
\hline Grupo de advogados & 1 \\
\hline Advertainment online & 1 \\
\hline 1 & \\
\hline
\end{tabular}

FONTE: Elaborado pela autora 
Considerando-se a classificação de Gupta et al (2011, p. 4), quanto à possível forma de as empresas estarem presentes nas mídias sociais, constatou-se que a amostra estudada está num estágio preliminar de atuação nesta mídia. Esta conclusão está baseada no fato de que não foram mencionados esforços de criação de fóruns de discussão e que somente um entrevistado mencionou dedicação à criação de conteúdo nas redes advertainment online.

Finda a etapa de identificação das ferramentas de comunicação offline e online consideradas mais importantes pela amostra pesquisada, em seguida será apresentada uma proposta de sistematização dessas ações.

\subsubsection{Ferramentas de comunicação por mercado-alvo e objetivos}

Tendo em vista as ações de comunicação apontadas como de maior importância pelos entrevistados, a Figura 21 ilustra uma proposta de organização destas ações segundo os mercados-alvo e seus objetivos.

\begin{tabular}{|c|c|c|c|c|}
\hline ర્ટ & MASSA & \multicolumn{2}{|c|}{ SEGMENTOS } & INDIVÍDUO \\
\hline \multirow{2}{*}{ 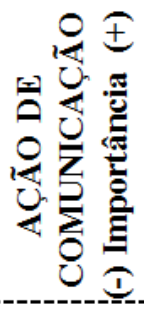 } & \multirow[t]{2}{*}{ Propaganda ${ }^{1}$} & & & $\begin{array}{l}\text { Marketing de } \\
\text { relacionamento }\end{array}$ \\
\hline & & $\begin{array}{l}\text { Patrocínio de } \\
\text { evento }\end{array}$ & $\begin{array}{l}\text { Mídias } \\
\text { sociais }^{2}\end{array}$ & Marketing direto ${ }^{3}$ \\
\hline 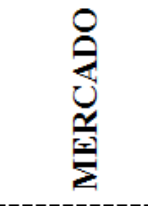 & $\begin{array}{c}\text { B2C } \\
\text { B2B } \\
\text { Stakeholders }\end{array}$ & $\begin{array}{c}\text { B2C } \\
\text { B2B } \\
\text { Stakeholders }\end{array}$ & $\begin{array}{c}\text { B2C } \\
\text { B2B } \\
\text { Stakeholders }\end{array}$ & $\begin{array}{l}\mathrm{B} 2 \mathrm{~B} \\
\mathrm{~B} 2 \mathrm{C}\end{array}$ \\
\hline$\sum_{0}^{0}$ & $\begin{array}{l}\text { Promoção da marca } \\
\text { e produtos e venda }\end{array}$ & $\begin{array}{c}\text { Promoção da marca } \\
\text { e produtos }\end{array}$ & $\begin{array}{l}\text { Promoção da } \\
\text { marca, produtos e } \\
\text { relacionamento }\end{array}$ & $\begin{array}{l}\text { Promoção da } \\
\text { marca, produtos, } \\
\text { venda e } \\
\text { relacionamento }\end{array}$ \\
\hline
\end{tabular}

${ }^{1}$ Considera propaganda offline e online

${ }^{2}$ Mídias sociais incluem ações, advertainment online, iniciativas nas redes sociais; Facebook, Twitter, YouTube, blogs, monitoramento e interação com advogados/promotores da marca e produtos e detratores ${ }^{3}$ Inclui ações de marketing direto offline e online

Figura 21 - Ações de comunicação offline e online segundo mercados-alvo e objetivos 
FONTE: Elaborado pela autora.

Conforme pode ser constatado na Figura 21, as ações de comunicação mais importantes destacadas pelos entrevistados são propaganda e marketing de relacionamento, mas seus focos são distintos. Enquanto a propaganda objetiva atingir a massa, ou seja, os mercados B2C, B2B e os stakeholders como um todo, as ações de marketing de relacionamento descritas pelos entrevistados são orientadas para o indivíduo, seja ele pessoa física ou jurídica.

O grupo de ações de comunicação de importância intermediária é formado por três ferramentas do mix de comunicação: patrocínio, mídias sociais e marketing direto. Os dois primeiros com foco em segmentos de consumidores, e o último com foco em clientes individuais, tanto B2C quanto B2B.

A seguir serão apresentadas as métricas aplicadas à avaliação dos investimentos em comunicação offline e online citados como mais importantes.

\subsubsection{Métricas das ferramentas de comunicação offline e online mais significativas}

Neste tópico serão destacadas todas as métricas citadas pelos entrevistados para as mais significativas ações de comunicação offline e online.

As entrevistas foram conduzidas de forma a levantar as métricas relativas às ações de comunicação destacadas pelos entrevistados como mais importantes. Algumas métricas foram apontadas como aplicadas para mais de uma ferramenta de comunicação e tanto para ferramentas de comunicação offline quanto online.

A Tabela 6 relaciona as métricas às diferentes ferramentas de comunicação offline e online e, às respectivas categorias adotadas para a análise de conteúdo.

Tabela 6 - Métricas adotadas para ações de comunicação offline e online e categorias de análise de conteúdo

\begin{tabular}{|c|c|c|c|}
\hline Métricas & Ação do mix de comunicação & Categoria & Citações \\
\hline & Mídias Sociais ${ }^{1}$ & CON3 & \\
Número de cliques & Marketing de Relacionamento & COF9 & 7 \\
\hline
\end{tabular}




\begin{tabular}{|c|c|c|c|}
\hline & Marketing Digital & CON1 & \\
\hline Pageviews & $\begin{array}{c}\text { Mídias Sociais } \\
\text { Marketing de Relacionamento } \\
\text { Marketing Digital }\end{array}$ & $\begin{array}{l}\text { CON3 } \\
\text { COF9 } \\
\text { CON1 }\end{array}$ & 6 \\
\hline Vendas & $\begin{array}{c}\text { Propaganda } \\
\text { Marketing de Relacionamento } \\
\text { Patrocínio } \\
\text { Marketing Direto } \\
\text { Marketing Digital } \\
\text { Mídias Sociais } \\
\end{array}$ & $\begin{array}{l}\text { COF1 e CON1 } \\
\text { COF9 } \\
\text { COF3 } \\
\text { COF5 } \\
\text { CON1 } \\
\text { CON3 } \\
\end{array}$ & 6 \\
\hline Relacionamento/CRM & $\begin{array}{c}\text { Marketing de Relacionamento } \\
\text { Patrocínio } \\
\text { Marketing Direto } \\
\text { Marketing Digital }\end{array}$ & $\begin{array}{l}\text { COF9 } \\
\text { COF3 } \\
\text { COF5 } \\
\text { CON1 }\end{array}$ & 5 \\
\hline Satisfação de cliente & $\begin{array}{c}\text { Marketing de Relacionamento } \\
\text { Patrocínio } \\
\text { Marketing Direto } \\
\text { Mídias Sociais } \\
\text { Marketing Digital } \\
\end{array}$ & $\begin{array}{l}\text { COF9 } \\
\text { COF3 } \\
\text { COF5 } \\
\text { CON3 } \\
\text { CON1 }\end{array}$ & 4 \\
\hline $\begin{array}{l}\text { Perfil de quem viu } \\
\text { site ou redes }\end{array}$ & $\begin{array}{c}\text { Mídias Sociais } \\
\text { Marketing Digital } \\
\end{array}$ & $\begin{array}{l}\text { CON3 } \\
\text { CON1 }\end{array}$ & 4 \\
\hline Páginas mais logadas & $\begin{array}{c}\text { Mídias Sociais } \\
\text { Marketing Digital }\end{array}$ & $\begin{array}{l}\text { CON3 } \\
\text { CON1 }\end{array}$ & 4 \\
\hline Fluxo das visitas & $\begin{array}{c}\text { Mídias Sociais } \\
\text { Marketing Digital }\end{array}$ & $\begin{array}{l}\text { CON3 } \\
\text { CON1 }\end{array}$ & 4 \\
\hline $\begin{array}{l}\text { Taxa de visualização } \\
\text { de e-mail marketing }\end{array}$ & Marketing Direto & COF5 & 4 \\
\hline $\begin{array}{l}\text { Monitoramento das } \\
\text { manifestações nas } \\
\text { redes sociais }\end{array}$ & Mídias Sociais & CON3 & 3 \\
\hline $\begin{array}{l}\text { Resultado financeiro } \\
\text { de feira }\end{array}$ & Patrocínio & COF3 & 3 \\
\hline Awareness & Propaganda & COF1 e CON1 & 3 \\
\hline $\begin{array}{l}\text { Monitoramento da } \\
\text { concorrência }\end{array}$ & $\begin{array}{l}\text { Mídias Sociais } \\
\text { Publicidade/RP }\end{array}$ & $\begin{array}{l}\mathrm{CON} 3 \\
\mathrm{COF} 2\end{array}$ & 3 \\
\hline $\begin{array}{l}\text { Avaliação da marca/ } \\
\text { atributos da marca }\end{array}$ & $\begin{array}{c}\text { Propaganda } \\
\text { Patrocínio } \\
\end{array}$ & $\begin{array}{c}\text { COF1 e CON1 } \\
\text { COF3 }\end{array}$ & 3 \\
\hline $\begin{array}{l}\text { ROI de cada ação de } \\
\text { comunicação }\end{array}$ & $\begin{array}{c}\text { Propaganda } \\
\text { Marketing de Relacionamento } \\
\text { Marketing Direto } \\
\text { Patrocínio } \\
\text { Mídias Sociais } \\
\text { Publicidade/RP } \\
\text { Marketing Digital } \\
\text { Promoção de vendas } \\
\end{array}$ & $\begin{array}{l}\text { COF1 e CON1 } \\
\text { COF9 COF5 } \\
\text { COF3 CON3 } \\
\text { COF2 } \\
\text { CON1 } \\
\text { COF4 }\end{array}$ & 2 \\
\hline Conversão & $\begin{array}{c}\text { Marketing de Relacionamento } \\
\text { Marketing Direto } \\
\text { Patrocínio }\end{array}$ & $\begin{array}{c}\text { COF9 COF5 } \\
\text { COF3 }\end{array}$ & 2 \\
\hline Engajamento na rede & Mídias Sociais & CON3 & 2 \\
\hline Recall & Propaganda & COF1 e CON1 & 2 \\
\hline
\end{tabular}




\begin{tabular}{|c|c|c|c|}
\hline & Patrocínio & COF3 & \\
\hline Top of mind & Propaganda & COF1 e CON1 & 2 \\
\hline COM & $\begin{array}{c}\text { Propaganda } \\
\text { Patrocínio }\end{array}$ & $\begin{array}{c}\text { COF1 e CON1 } \\
\text { COF3 }\end{array}$ & 2 \\
\hline $\begin{array}{c}\text { Taxa de retorno de } \\
\text { clientes participantes } \\
\text { de patrocínios }\end{array}$ & Patrocínio & COF3 & 2 \\
\hline $\begin{array}{c}\text { Avaliações externas } \\
\text { como prêmios }\end{array}$ & $\begin{array}{c}\text { Propaganda } \\
\text { Marketing Digital }\end{array}$ & $\begin{array}{c}\text { COF1 e CON1 } \\
\text { CON1 }\end{array}$ & 1 \\
\hline $\begin{array}{c}\text { Brand } \text { valuation } \\
\text { Retenção }\end{array}$ & Propaganda & COF1 e CON1 & 1 \\
\hline $\begin{array}{c}\text { Marketing de Relacionamento } \\
\text { Marketing Direto } \\
\text { Patrocínio }\end{array}$ & $\begin{array}{c}\text { COF9 COF5 } \\
\text { COF3 }\end{array}$ & 1 \\
\hline $\begin{array}{c}\text { Pesquisa qualitativa } \\
\text { (conceito e }\end{array}$ & $\begin{array}{c}\text { Propaganda } \\
\text { Patrocínio }\end{array}$ & $\begin{array}{c}\text { COF1 e CON1 } \\
\text { COF3 }\end{array}$ & 1 \\
\hline
\end{tabular}

${ }^{1}$ Mídias sociais incluem iniciativas nas redes sociais; Facebook, Twitter, YouTube, blogs, monitoramento e interação com advogados/promotores da marca e produtos e detratores

2 Brand Equity

FONTE: Elaborado pela autora

Vendas é a métrica mais versátil para apuração de resultados, tendo sido associada à avaliação de seis ações de comunicação: propaganda, marketing de relacionamento, patrocínio, marketing direto, mídias sociais e marketing digital. Dentre estas ações de comunicação, duas são exclusivamente online: marketing digital (CON1) e mídias sociais (CON3). Apesar das ferramentas propaganda (COF1), patrocínio (COF3) e marketing de relacionamento (COF9) serem ações de comunicação aplicáveis no ambiente offline e online, a métrica vendas foi indicada pelos entrevistados especificamente para ações offline. Em relação às ações de marketing direto (COF5), a métrica vendas foi apontada tanto para ações offline quanto ações online.

A adoção da métrica vendas requer cuidados, conforme indicado por alguns autores na fundamentação teórica. Para Ogden e Crescitelli (2007, p. 51), a avaliação dos resultados deve envolver os objetivos e indicar como estes serão atingidos. Os autores destacam o risco de a avaliação ser baseada em vendas, resultado influenciado pelo composto de marketing como um todo e não somente por um de seus itens. Neely (2002, p. 48) reitera as restrições de uso de vendas para avaliar os resultados de ações de marketing, pois no afã de alcançar o objetivo de vendas, pode-se optar pela redução de preço do produto. 
Concluída a classificação das métricas de acordo com as categorias dos elementos do mix de comunicação, foi feita a análise das métricas correspondentes às ações de comunicação mais adotadas pelos bancos entrevistados neste estudo.

\subsubsection{Métricas de avaliação de propaganda}

As métricas apontadas pela amostra para a avaliação de ações de propaganda estão apresentadas na Tabela 7.

Tabela 7 - Métricas de avaliação de propaganda

\begin{tabular}{|c|c|}
\hline Métricas & Citações \\
\hline Vendas & 6 \\
\hline Awareness & 3 \\
\hline Avaliação da marca/ atributos da marca & 3 \\
\hline ROI de cada ação de comunicação & 2 \\
\hline Recall & 2 \\
\hline Top of mind & 2 \\
\hline Auditoria de imagem & 2 \\
\hline COM & 2 \\
\hline Avaliações externas como prêmios & 1 \\
\hline Brand valuation & 1 \\
\hline Pesquisa qualitativa (conceito e posicionamento) & 1 \\
\hline
\end{tabular}

FONTE: Elaborado pela autora

A análise das métricas de propaganda considerará a propaganda offline, pois não foram indicadas métricas específicas às ações de propaganda online.

A métrica vendas foi citada por representantes de seis dos sete bancos entrevistados. Em seguida, três bancos mencionaram avaliarem os efeitos da propaganda por meio de consciência ou awareness da marca, conforme mencionado: 
A gente não tem uma métrica consistente. Em relação à awareness a gente faz pesquisa de mercado, a pesquisa vai ser feita no ano que vem, para medir 2011 , então a gente vai entender se a gente engrossou o nosso awareness.

(...) o objetivo de awareness mesmo, para que a gente consiga engrossar nossa pirâmide (...)a gente tem que começar pela awareness (....), geralmente a awaraness tem tudo a ver com a capilaridade.

(...) Eu preciso que a marca seja conhecida (...). Primeiro, eu vou reforçar a marca (...).

Algumas empresas da amostra avaliam os resultados dos investimentos em propaganda por meio de pesquisas de avaliação de atributos da marca, conforme destacado por três bancos:

A gente tem alguns trakings, o maior deles (...) é uma pesquisa trimestral (...) e eu olho a força da marca baseada em cinco atributos, cinco aspectos da força da marca nestas praças e aí a gente sabe a oscilação.

(...) auditoria de imagem que faz uma verificação do índice de positividade, negatividade, , como nós estamos em relação aos concorrentes.

(...) um tracking que a gente faz mensal trimestral, dependendo das medidas e aí a gente define um série de atributos de marca e de métricas de marca que a gente quer (...).

A métrica de Top of mind, pesquisa anual realizada pela Folha de S. Paulo, foi citada por dois entrevistados de distintos bancos.

(...) tem o Top of Mind da área de indústria financeira.

(...) então vai desde Top of Mind, até preferência pela marca, melhor marca, recomendação, todas aquelas questões do funil de marketing: consideração, preferência, lealdade.

A avaliação de ações de propaganda na mídia revista foi considerada difícil por um respondente:

(...) é um gap que eu tenho hoje (...). A gente não tem uma forma de avaliar a revista separadamente hoje, ela vai no bolo da publicação, mas é um território importante.

\subsubsection{Métricas de marketing de relacionamento}

A Tabela 8 apresenta as métricas apontadas pela amostra para a avaliação de ações de marketing de relacionamento. 


\section{Tabela 8 - Métricas de avaliação de marketing de relacionamento}

\begin{tabular}{|c|c|}
\hline Métricas & Citações \\
\hline Número de cliques & 7 \\
\hline Vendas & 6 \\
\hline Pageviews & 6 \\
\hline Relacionamento/CRM & 5 \\
\hline Satisfação de cliente & 4 \\
\hline Retenção & 1 \\
\hline
\end{tabular}

FONTE: Elaborado pela autora

Representantes de todos os bancos entrevistados mencionaram a métrica número de cliques para ações de mídias sociais, quando esta foi indicada com a finalidade de relacionamento.

Em seguida foram citados vendas e pageviews. Esta última métrica também relacionada às mídias sociais. Sobre vendas, sua menção foi associada tanto a esforços de marketing de relacionamento quanto à satisfação de cliente.

As métricas relacionadas especificamente ao relacionamento com cliente ou CRM, foram apontadas por entrevistados de cinco instituições e são relacionadas ao acompanhamento do histórico do cliente, tais como contratações de novos serviços. A seguir, trechos das entrevistas que explicam em que consistem as métricas de ações de relacionamento/CRM.

O relacionamento do banco, a forma mais objetiva de medir é posse de produtos. Se o cliente tem potencial, mas consome pouco, significa que não é o banco principal.

(...) por meio da gestão de CRM, justamente com o objetivo de medir os resultados de conversão e retenção dos clientes. (...) Então nós usamos a ferramenta de CRM justamente para isso, para medir o retorno do investimento mesmo. Então hoje na realidade, nós temos nesta ferramenta todo o histórico do que aconteceu, quais foram as empresas que participaram, quais empresas não eram clientes do banco e a gente faz uma avaliação três meses depois da ação ter acontecido (...).

(...) O prazo de três meses para avaliação, é de uma maneira geral, o prazo para que a uma coisa possa acontecer, e também passando disso, agente perde o efeito até porque normalmente um cliente pesquisa. Ele vai ouvir a proposta, mas não é uma coisa concluída no ato $(\ldots)$. 
(...) na verdade aí a métrica no final a gente acaba usando sempre o CRM. O CRM hoje pra gente é uma ferramenta que gera histórico, a gente tem todo tipo de contato que o gerente do banco teve com o cliente, seja uma mala direta que foi enviada, seja outro tipo de comunicado, seja uma visita que foi realizada.

(...) por isso que acho que hoje a ferramenta de CRM é fundamental numa empresa, porque você tem ali, tudo que você já fez ou pretende fazer para determinado cliente. E ser o mais direcionado possível, ser o mais exclusivo, e personalizado possível, acho que esta é que é a ideia mesmo.

FARRIS et al, (2007, p. 145) ressaltam que a avaliação da rentabilidade do cliente tem o intuito de gerar uma orientação para o cliente, e não para as unidades vendidas. Por meio desta abordagem, a empresa é capaz de identificar o desempenho financeiro passado das relações com os clientes e desenvolver ações específicas que preservem o relacionamento futuro e possibilitem sua rentabilidade.

Quatro entrevistados mencionaram a satisfação de cliente. Essa métrica é influenciada por esforços de relacionamento e também por ação de patrocínio e atendimento ao cliente.

Somente um entrevistado mencionou o conceito de LTV e, de acordo com sua opinião, os bancos ainda não incorporaram plenamente o relacionamento na gestão de seus clientes.

(..) isso (foco em LTV) pode acontecer com as empresas que têm preocupação com o turnover do cliente, que a gente chama de churn de clientes, mas de maneira desagregada (...) porque a maioria das pessoas pensa em produto. $80 \%$ do mercado ainda vê produto, as pessoas não estão preocupadas com o retorno do cliente, mas que o cliente consuma $\mathrm{X}$ ou $\mathrm{Y}$ produtos. Esta equação deve mudar para o P\&L por cliente, conceito antigo nos EUA, mas aqui as empresas ainda se organizam por P\&L por produto.

Portanto, o LTV não é considerado uma métrica de avaliação de ações de marketing de relacionamento pela amostra estudada.

\subsubsection{Métricas de patrocínio}

A Tabela 9 apresenta a relação de métricas adotadas para avaliação de resultados de patrocínios. 
Tabela 9 - Métricas de avaliação de patrocínio

\begin{tabular}{|c|c|}
\hline Métricas & Citações \\
\hline Vendas & 6 \\
\hline Relacionamento/CRM & 5 \\
\hline Satisfação de cliente & 4 \\
\hline Resultado financeiro de feira & 3 \\
\hline ROI de cada ação de comunicação & 2 \\
\hline Conversão & 2 \\
\hline Recall & 3 \\
\hline Avaliação da marca/ atributos da marca & 2 \\
\hline COM & 2 \\
\hline Taxa de retorno de clientes participantes de patrocínios & 1 \\
\hline Retenção & 1 \\
\hline Pesquisa qualitativa (conceito e posicionamento) & \\
\hline
\end{tabular}

FONTE: Elaborado pela autora

Uma das razões para a escolha do setor estudado foi o fato dos serviços prestados pelos bancos envolverem a possibilidade de estabelecimento de um relacionamento de longo prazo, motivo reiterado pelos entrevistados.

Segundo um entrevistado, utiliza-se o patrocínio com o intuito de proporcionar uma experiência aos seus clientes, em consonância com definição de Close et al (2006, p.420),

(...) está usando o patrocínio de uma forma mais holística, para ter um pouco desta coisa da experiência da marca, da presença de uma forma mais relevante.

Foi constatado que as ações de patrocínio são mais do que um meio de construção de marcas como proposto por Aaker e Joachimsthaler (2000, p. 217).

A partir do conteúdo da Tabela 8 - Relacionamento/CRM, satisfação, conversão e retenção -, é possível verificar o potencial que as ações de patrocínio têm para os bancos gerenciarem o relacionamento com seus clientes. Para a amostra, patrocínios 
são, portanto, uma forma de estreitar relacionamento com clientes. Dois entrevistados destacaram a promoção de "eventos de relacionamento".

Segundo os entrevistados e, em linha com Hersch (2007), os eventos patrocinados pelos bancos também têm como público-alvo seus clientes potenciais ou prospects, por isso a avaliação do resultado destes eventos considera a contratação do banco por novos clientes.

(...) então hoje na realidade, nós temos nesta ferramenta todo o histórico do que aconteceu, quais foram as empresas que participaram, quais empresas não eram clientes do banco naquele momento e a gente faz uma avaliação três meses depois de a ação ter acontecido. Compara o resultado das empresas que participaram e bate com o que aconteceu depois de três meses da ação (do evento) e consegue trazer o retorno sobre o investimento, como também consegue conhecer quais os clientes que não eram nossos, quais as dificuldades que a gente tinha para entrar nestas empresas e, de repente, por meio de um evento, conseguimos nos aproximar e abrir as portas mais facilmente.

A fim de viabilizar a gestão de seus clientes, os entrevistados de instituições que investem em patrocínio de eventos para relacionamento utilizam CRM - gestão de bancos de dados - para a medição dos resultados. A avaliação dos resultados ocorre ao longo de um período que oscila entre três e seis meses após a realização do evento.

(...) nós temos a taxa de retorno dos convites dos clientes, nível de satisfação dos clientes quando são agraciados com convite para assistir algum show, espetáculo, margem de contribuição desses clientes, ou seja, se o relacionamento dele com o Banco aumenta ou não, então a gente faz esta verificação dos eventos, então tudo, digamos o evento que a gente patrocina, seja no patrocínio de oportunidade ou dentro do nosso programa de patrocínio anual, a gente faz a verificação da taxa de retorno deste patrocínio.

Algumas métricas adotadas para avaliação de patrocínio são CPM e publicidade gerada, ambos mencionados por um entrevistado:

(...) quando o evento é grande (...) eu olho algumas coisas, o CPM das pessoas impactadas. Então tem um evento para o qual foram cinco mil pessoas, o evento custou tanto, então o CPM deste evento é tanto. Este é um aspecto, outro aspecto é a mídia espontânea gerada, a gente tem uma assessoria de imprensa que contrata uma empresa que mede a centimetragem gerada com a marca e quanto isso vale em dinheiro. (...) outro ponto é que em todos estes eventos têm um espaço exclusivo para relacionamento com clientes (...).

Segundo Shimp (2002), Rosenwald (2005) e Baker (2005), o LTV depende de informações complicadas de serem obtidas ou previstas, tais como quanto o cliente comprará da empresa, ao longo de qual período e proporcionando qual margem. Devido à facilidade de as instituições estudadas alimentarem os bancos de dados de seus 
clientes, a avaliação do LTV de seus clientes é acessível, pois é possível estimar o retorno de diferentes ações promocionais e orientar a estratégia de relacionamento com seus clientes.

\subsubsection{Métricas de marketing direto}

A Tabela 10 apresenta as métricas adotadas para avaliação de resultados de Marketing direto.

Tabela 10 - Métricas de avaliação de marketing direto

\begin{tabular}{|c|c|}
\hline Métricas & Citações \\
\hline Vendas & 6 \\
\hline Relacionamento/CRM & 5 \\
\hline Taxa de visualização de e-mail marketing & 4 \\
\hline Satisfação de cliente & 4 \\
\hline ROI de cada ação de comunicação & 2 \\
\hline Conversão & 1 \\
\hline Retenção & 2 \\
\hline
\end{tabular}

FONTE: Elaborado pela autora

As ações de marketing direto offline e online são relacionadas à estratégia de relacionamento das instituições bancárias. Os profissionais de comunicação entrevistados demonstraram valorizar e medir as ações desta natureza, por meio principalmente, da gestão das informações do banco de dados de seus clientes.

A área de CRM (...) coordena todas as ações de marketing direto, (...) de banco de dados de clientes, ferramentas de campanha. As ações mais importantes em relação aos canais de marketing direto (...) mala direta, e-mail e rede de agências, internet, telefone.

Nossa área de CRM tem uma área de ferramentas, tem uma área de atendimento que tem pessoas que interagem com todos os gestores. Então a gente tem os especialistas em financiamento, cartão de crédito, previdência, seguradoras, em cada área tem as pessoas que interagem com eles (...).

O banco de dados também é essencial para a mensuração dos resultados das atividades de marketing direto: 
No marketing direto a gente tem um sistema de CRM, eu sei quantas malas eu mando qual o custo total dessas malas, e qual o retorno contratado desta ação no tempo, isto eu consigo avaliar então BTL.

A criação de um grupo de controle foi apontada como essencial para a avaliação dos resultados das ações de comunicação de marketing direto e de comunicação online. A proposta é preservar um grupo que não será exposto à campanha para avaliar o real impacto da ferramenta adotada, conforme descrição de dois entrevistados:

(...) pego a base que foi quem foi impactado, pego uma base que não foi impactada que é o grupo de controle e a gente mede, quanto que as duas movimentaram. A diferença percentual de uma para a outra é o resultado da mala direta.

(...) primeiro qual é o público que a gente quer atingir, deste público já era separado sempre o grupo de controle. Feito esse grupo de controle, nós também blindamos este grupo de controle de outras ações. Uma dificuldade muito forte é você fazer com que aquele grupo, seja o de controle, seja o da ação, esteja submetido só àquela ação.

Para uma efetiva avaliação dos resultados, este grupo deve ser isolado de outras ações de comunicação, conforme mencionado por dois entrevistados especialistas no setor de relacionamento:

(...) desse público já era separado sempre o que a gente chamava grupo de controle. Feito esse grupo de controle, nós também blindávamos este grupo de controle de outras ações.

(...) como estou te falando, mala direta, marketing direto, normalmente estas ações tendem a ter um resultado. É, mais tangível, porque você consegue controlar a base e o objetivo é penetrar mais produtos nas bases do Banco.

Conforme relato de um entrevistado, além das métricas de marketing direto permitirem a avaliação dos objetivos preestabelecidos, também podem ser utilizadas para garantir a eficácia desta ação e evitar uma carga excessiva de mensagens.

(...) infelizmente, a gente não pode afirmar que ele (o cliente) leu toda a mensagem enviada, eu sei que ele abriu. O que é controlado é na verdade: a frequência de envio de emails, ela é dosada para que a taxa de visualização não fique abaixo de um determinado patamar. (...) Isso é uma coisa que a gente acompanha. Se mandar muitos e-mails, ele começa a baixar sem ler. Acha que o banco está enchendo, abusando de mandar tanto email, não quero receber tanto e-mail. Para e-mail as métricas são: índice de enviados com sucesso e índice de visualização

Esta prática é viável devido ao fato de as ações de marketing direto serem mais controláveis do que a propaganda ATL, que são orientadas para um público de massa. 
No marketing direto é possível um controle e acompanhamento mais rigoroso do comportamento do público-alvo comparativamente a uma amostra não exposta às mesmas ações.

(...) quando faz campanha offline de seguro faz (também) online e é capaz de saber quantos cliques teve naquela peça. $\mathrm{O}$ cliente faz login e consegue saber quantos clientes viram uma peça e pra e-mail marketing faz a mesma medição de mala direta para saber quem foi impactado quem mexeu e quem não mexeu e consegue saber o que aquele e-mail marketing deu de resultado.

(...) na parte de patrocínio nós também temos (...) a taxa de retorno dos convites dos clientes, nível de satisfação dos clientes quando são agraciados com convite para assistir algum show, espetáculo, margem de contribuição desses clientes, ou seja, se o relacionamento com o banco aumenta ou não, então a gente faz esta verificação dos eventos, então tudo, digamos o evento que a gente patrocina, seja no patrocínio de oportunidade ou dentro do nosso programa de patrocínio anual, a gente faz a verificação da taxa de retorno deste patrocínio.

\subsubsection{Métricas de mídias sociais}

As métricas adotadas para avaliação de resultados de mídias sociais estão apresentadas na Tabela 11.

Tabela 11 - Métricas de avaliação de mídias sociais

\begin{tabular}{|c|c|}
\hline Métricas & Citações \\
\hline Número de cliques & 7 \\
\hline Pageviews & 6 \\
\hline Vendas & 6 \\
\hline Relacionamento/CRM & 5 \\
\hline Satisfação de cliente & 4 \\
\hline Perfil de quem viu site ou redes & 4 \\
\hline Páginas mais logadas & 4 \\
\hline Fluxo das visitas & 3 \\
\hline Monitoramento das manifestações nas redes sociais & 3 \\
\hline Monitoramento da concorrência & 2 \\
\hline ROI de cada ação de comunicação & 2 \\
\hline Engajamento na rede & 4 \\
\hline
\end{tabular}

FONTE: Elaborado pela autora 
A partir da Tabela 11 é possível observar que as métricas mais citadas pelos entrevistados para a avaliação de ações em mídias sociais referem-se à internet de forma geral. Essas métricas são aplicadas às mídias sociais, ações de relacionamento na internet - redes e e-mail marketing - e marketing digital. Métricas específicas como monitoramento das manifestações nas redes, da concorrência e engajamento ainda não são priorizadas na gestão de ações nas mídias sociais.

Em consequência da predominância de métricas genéricas à internet, neste tópico será considerado e analisado o conjunto das métricas aplicadas na dimensão online.

A mensuração dos resultados das ações online é mais fácil e objetiva, conforme três manifestações.

Na parte ATL de mídia online tem hot site, toda a nossa campanha está em hot site. O que consegue fazer, trackeou toda a página, o que significa saber se o cliente clicou na minha página, no que e se ficou lá, se abre sua conta. É muito mais fácil quantificar os resultados, pois sei quem clicou, quem veio do Facebook, quais estão online e quais clicaram no quê.

Você entra no YouTube, um vídeo foi assistido por 1 a 2 milhões de pessoas então não precisa nem de ferramenta, a medida é ali. Você abre, clica. É automático, então a gente acompanha.

Pra vídeo tem um negócio muito interessante qual parte do vídeo você vê, se viu um pedaço do vídeo, se avança, qual a parte que mais gosta.

No entanto, a precisão das estatísticas online nem sempre é suficiente para entender se a contratação de um serviço foi provocada por aquela ação na internet.

(...) dá para medir a digital, principalmente quando você faz Google e links patrocinados (...) e YouTube porque eu pago por acesso, então eu quero que as pessoas ao digitar um serviço, caiam primeiro no banco. Se você clicar no serviço x, eu pago para o Google o resultado daquilo. Eu sei o quanto paguei, quantas pessoas se informaram, quantas contrataram aquele serviço, quantas entraram no meu hot site no meu site para ver, para se informar sobre o serviços do banco ou assistir uma propaganda que eu postei no YouTube falando do serviços, mas de novo, não significa que ele contratou. São duas coisas diferentes, eu posso ter aumentado o conhecimento da Previdência, a preferência da Previdência a consideração, mas não fiz a conversão.

A mensuração das ações de comunicação online subsidiarão as decisões futuras:

$\mathrm{Na}$ etapa de acompanhamento dos resultados do processo de comunicação, entram as métricas - veículos com maiores taxas de clique, os menores custos/clique. Priorizam as melhores performances aumentando os investimentos. Ao final da veiculação tem o aprendizado da campanha. 
Segundo os entrevistados, no que tange aos esforços de relacionamento das mídias sociais, os bancos dedicam-se aos clientes preferenciais ou de maior valor e também àqueles com capacidade de propagar sua marca e seus produtos. Os entrevistados apontaram também preocupar-se com os detratores, aptos a comprometer desfavoravelmente a marca do banco, as submarcas adotadas em diferentes segmentos de clientes e seus produtos:

\footnotetext{
Uma outra medida que a gente usa agora no Facebook por exemplo, é o engajamento, uma coisa é você ter fã que vão lá e outra coisa é você ter pessoas que dão um curtir que se envolvem, que replicam sua mensagem para outros, então tem uma série de metodologias que você olha e começa a olhar o engajamento (....) e aí as métricas são muito variadas é desde estudos essas pesquisas que saem rankings de maior engajamento, até quantas pessoas vieram aquilo, então quantos views, quantos likes e quantos dislikes também, você tem os detratores e os amantes da marca. Já estamos começando a formar grupos com os brand advocates, os caras que amam a marca, para começar a fazer pesquisa on line com eles (...).

(...) a gente vê em literatura e pessoal de consultores de fora, dizendo que você deve interagir com os clientes de maior valor. O banco adotou como postura interagir com todos. Qualquer reclamação, não importa o valor, qualquer manifestação, reclamação de qualquer coisa (...) imediatamente manda um post.
}

Concluída a etapa de análise das métricas das ações de comunicação serão apresentados os resultados da comparação entre as métricas de avaliação de comunicação offline e online.

\subsubsection{Comparação de métricas de avaliação de ações de comunicação offline com ações online}

Sobre a comparação dos resultados de ações de comunicação offline com online, a maioria dos bancos não faz nenhum tipo de comparação.

De acordo com os entrevistados, a tradicional propaganda na TV aberta e fechada tem um CPM muito superior ao similar na internet. No entanto, tendo em vista a irrefutável importância desta tradicional mídia na vida do consumidor do século XXI, os bancos não podem ignorá-la.

Sim, comparam (...) mais para aculturamento, pois são coisas desproporcionais e não dá para comparar para fazer decisão. Não dá para sair de TV aberta. Uma produção de um filme sai por $\mathrm{R} \$ 800$ mil, $\mathrm{R} \$ 15$ milhões num flight e atinge 70 a 100 milhões, mais qual o nível de apreensão comparado com a atenção de um tutorial? 
A TV mantém uma elevada importância, sendo líder em penetração no mercado brasileiro.

Se você começar a comparar para tomar decisão, você vai sair de tudo que é TV aberta e sei lá o quê e vai ficar. Só na mídia social, não dá.

Por outro lado, a internet é relevante para o setor de bancos, prestador de serviços de massa, tanto para a propaganda de massa, quanto para busca de palavras-chave e links patrocinados, mas, sobretudo, para ações de marketing direto que, tal como no caso do seu similar offline, é facilmente mensurável.

Há heterogeneidade quanto aos objetivos que justificam a adoção da internet. Há bancos que desenvolvem campanhas específicas para esta mídia. Outras instituições atribuem mais importância às redes sociais e desenvolvem ações exclusivas para esta mídia.

Apesar de oferecerem um serviço de massa, poucos bancos exploram as cinco formas de atuação na mídia social: blogs, redes sociais, Twitter, fóruns de discussão com avaliação de clientes e desenvolvimento e busca de conteúdo relevante para seu negócio, conforme indicado por Gupta et al (2011, p. 4). Também foram identificadas poucas iniciativas de interação regular na mídia social e monitoramento do comportamento do internauta.

No que tange às mídias adotadas para ações de comunicação, além das mídias tradicionais - TV, revista, jornal, rádio, internet, etc. - , o setor bancário dispõe de mídias específicas como ATM e internet banking, ambas adotadas para acompanhamento e movimentação da conta corrente - pagamentos, transferências e aplicações.

A seguir serão apresentados alguns aspectos considerados relevantes para melhor entendimento e aplicação de métricas de avaliação dos resultados dos investimentos em comunicação. 


\subsubsection{Considerações sobre a adoção de métricas de avaliação dos investimentos em comunicação offline e online}

Dentre as nove métricas com quatro ou mais citações, oito são utilizadas para medir marketing direto; sete para avaliar os resultados atingidos em mídias sociais, seguidos de cinco ou menos métricas utilizadas para medir as categorias de comunicação offline.

Sobre as métricas apontadas pelos entrevistados, constatou-se a adoção de uma medida financeira de curto prazo, o ROI das diferentes ações de comunicação offline e online por dois entrevistados. No entanto, os dados coletados não apontam que a amostra pesquisada considere medidas de longo prazo como projeção do impacto dos investimentos em comunicação no Valor Presente Líquido (VPL) de todos os fluxos de caixa futuros. Por outro lado, foi possível identificar a adoção de medida não financeira de longo prazo, como brand equity (GUISSONI; NEVES, 2011, p.39), mesmo que com baixa incidência.

Comparando os resultados desta pesquisa com estudos sobre a adoção de métricas conduzidos nos últimos anos, no Brasil, constatam-se algumas semelhanças. Estudo de Almeida (2007) concluiu que as métricas mais conhecidas eram: satisfação dos clientes e número de clientes. A presente pesquisa constatou que satisfação é uma das métricas mais significativas para a amostra estudada, tendo sido citada por quatro dos bancos entrevistados.

Pesquisa de Queiroz (2008) revelou que as métricas mais usadas eram: crescimento das vendas e vendas, esta última citada também de forma significativa por seis dos sete bancos estudados. Esta métrica foi indicada para todas as ferramentas do mix de comunicação indicadas como mais importantes, ou seja, tanto para ações offline propaganda, marketing de relacionamento, patrocínio de evento e marketing direto, quanto online - propaganda, marketing de relacionamento, mídias sociais e marketing direto.

Por outro lado, outro estudo realizado pela Accenture (2009) junto a associados da ABA (Associação Brasileira de Anunciantes) indicou que a avaliação de atributos da marca era a métrica mais adotada por $95 \%$ da amostra estudada. Os resultados da presente pesquisa são incompatíveis com o dessa pesquisa, pois três entrevistados apontaram a 
métrica avaliação da marca ou de atributos da marca. Sua aplicação está relacionada predominantemente à propaganda.

Apesar de algumas distinções quanto ao nível de cobrança sobre a adoção de métricas e a diversidade de sua adoção, de maneira geral, os entrevistados demonstraram familiaridade e repertório quanto a métricas consagradas como vendas, awareness, recall, top of mind, relacionamento e satisfação do cliente.

Comparando as métricas citadas pela amostra com as métricas de marketing aplicáveis às ferramentas de comunicação levantadas na revisão de literatura - Quadro 3, é possível constatar a baixa adoção de métricas surgidas a partir da década de 90 como brand equity, CLV e qualidade de serviços.

Somente dois entrevistados disseram que os bancos aos quais estavam relacionados buscam avaliar o ROI de cada ação isolada. Outros entrevistados mencionaram não fazerem este tipo de avaliação devido à ausência de ferramenta.

Nenhum entrevistado citou a dimensão de geração de valor para o acionista, ou Valuebased communication (VBC) (BROADBENT; FRY, 1995; DOYLE, 2000) e customer equity (GUISSONI; NEVES, 2011).

Apesar de não ter sido encontrada na revisão uma classificação das empresas segundo a maturidade de adoção das métricas de avaliação dos investimentos em comunicação, os resultados indicam que a amostra estudada esteja num estágio intermediário. Esta conclusão é baseada no fato da amostra combinar métricas tradicionais - vendas, awareness, recall, top of mind, com métricas mais sofisticadas ou complexas de serem avaliadas como valor da marca e brand equity - estas duas com menor frequência - e outras que requerem a gestão de database de prospects e clientes, como métricas de relacionamento e satisfação do cliente.

Outro indicativo de um nível intermediário de maturidade é o fato de a amostra ter indicado preferir adotar vendas para avaliar os resultados atingidos por ações de marketing de relacionamento do que satisfação dos clientes ou CLV. Estudo realizado há quase uma década junto a empresas de cinco países europeus industrializados apontou que, após vendas, a métrica mais adotada, 77\% da amostra adotavam como métricas qualidade de serviços e $40 \%$ ciclo de vida do cliente (BARWISE; FARLEY, 2004). 
A respeito da classificação do mix de comunicação de marketing proposta por Ogden e Crescitelli (2007) em três grupos - tradicional,complementar e inovadora -, os resultados sugerem que para a amostra estudada, marketing de relacionamento já tenha status de uma ferramenta tradicional e não complementar.

Em relação às redes sociais, os resultados da pesquisa apontam que esta ação de comunicação possui relevância intermediária, assumindo status de ferramenta complementar para algumas instituições.

Quanto à ferramenta marketing digital essa não é tratada isoladamente pela amostra como uma ferramenta de comunicação. Os entrevistados apontaram que esta mídia tornou-se fundamental para as ações de propaganda, marketing direto e marketing de relacionamento, mas ainda é pouco explorada pelo setor para ações de patrocínio de eventos.

Os resultados levantados apontam que os profissionais possuem uma cultura de adoção de métricas, mas num estágio pouco avançado. Num setor conhecido pela prática de concessão de bônus, dois entrevistados sugeriram que a concessão de bônus aos profissionais envolvidos nas ações de comunicação seja vinculada ao alcance dos objetivos do negócio.

(...) se você não alinhar os indicadores, o profissional de marketing vai ficar tranquilo e vai para casa dele, achando que fez tudo perfeitamente, quando ele poderia ir para casa dele dizendo, eu até fiz minha parte mas o que eu posso fazer a mais que possa contribuir para que as vendas subam (...)Todo mundo tem que ganhar. Você precisa ir alinhando isto (resultado) à gestão de recursos humanos, e uma das coisas importantes são os mecanismos de incentivos (...).

(...) os funcionários da área de marketing têm por job description colocar campanhas de comunicação no ar, tem isso na meta de desempenho. Se você puser uma campanha no ar e não teve tempo, não conseguiu planejar a tempo (os objetivos), é penalizado na meta de desempenho do final do ano que vai gerar bônus.

Por conseguinte, uma recomendação para a efetividade de uma cultura de avaliação é que na etapa de planejamento da campanha estejam claros os objetivos a serem atingidos por cada ação de comunicação, se consciência da marca, posicionamento, estreitamento de relacionamento ou venda. Sem clareza nos objetivos, as métricas podem ficar soltas e serem somente mais um número, uma estatística a ser atingida.

Nós precisamos, antes de colocar no ar, entender, o que nós queremos medir, que indicador medirá isso e qual é o resultado que nós esperamos atingir (...) eu não ponho campanha no 
ar sem que haja um acordo sobre quais são os indicadores através dos quais aquela campanha será medida.

A gente tem lá as nossas métricas a gente tem metas anuais de quanto queremos crescer em cada uma destas métricas

A partir da definição prévia dos objetivos será possível estabelecer os indicadores apropriados.

Ainda para aprimorar a efetividade da avaliação dos resultados das ações de comunicação, sugere-se a incorporação de um viés mais quantitativo na formação do profissional que atua em comunicação. Falta à maior parte desses profissionais uma formação quantitativa que suporte uma cultura de mensuração e orientação para resultados. Desta forma, esses profissionais estariam mais aptos a atuar num ambiente orientado para resultados avaliados por meio de métricas e indicadores. Caso contrário, será preciso contratar profissionais com formação em áreas de exatas para suprir a lacuna de conhecimento de mensuração, como já vem sendo feito por algumas empresas.

O profissional de marketing tende a ter uma veia criativa e é motivado a aplicá-la em seu trabalho. Algumas empresas estão lidando com esta lacuna por meio da contratação de profissionais com formação em exatas como estatística ou matemática. Em alguns casos, são criadas áreas compostas por profissionais com este perfil para apoiar a área de comunicação de marketing. Esta ideia está expressa na fala de dois entrevistados:

O profissional de comunicação não gosta de métrica, porque ele estudou comunicação. O marketing sem a métrica é um marketing vazio.

(...) eu precisava inserir dentro da área de comunicação pessoas mais quantitativas, não só com conhecimento de matemática, mas também de método, para poder desenvolver isso que a gente está falando aqui, de mecanismos de controle, apurar os números e demonstrálos. Porque não é alguém de dentro da área de comunicação, normalmente que consegue fazer isso e vai ficar feliz de ficar gastando o tempo dele. Esse é um grande problema. A área de comunicação, muitas vezes não atrai pra dentro dela alguns profissionais, alguns elementos, que vai ter que atuar com muita sinergia com as outras pessoas, que conseguiria fazer esta parte quantitativa, essa contribuição e ajuda inclusive para que o cara de comunicação aperfeiçoe sua atividade.

Apesar de não ter havido o intuito de identificar se os bancos recorrem a uma métrica única para avaliação dos investimentos de comunicação, o estudo indicou que há esforços nesse sentido. 
O primeiro exemplo foi avaliação da marca, medida por meio da imagem ou do valor agregado da marca como consequência do conjunto das ações de comunicação.

(...) Há também pesquisa sobre key drives sobre abertura de conta no banco e como o banco está posicionado nesta característica. A marca aparece nos key drivers.

(...) um tracking que a gente faz mensal trimestral, dependendo das medidas e aí a gente define um série de atributos de marca e de métricas de marca que a gente quer, então vai desde Top of Mind, até preferência pela marca, melhor marca, recomendação, todas aquelas questões do funil de marketing, consideração, preferência, lealdade (...).

Foram indicados dois key driver para o sucesso das ações de comunicação. O primeiro é qualidade de serviços. O outro é capilaridade do banco, representada pela quantidade de agências.

(...) o mais importante é o basicão: quantidade de agência, qualidade do serviço e assim por diante.

A outra coisa que em banco existe e acho que em qualquer mercado, que tem loja de rua, existe uma correlação muito grande em a força da marca e a capilaridade. Existe esta relação muito 70 a $80 \%$, então geralmente a awaranesses tem tudo a ver com a capilaridade.

Outro parâmetro de avaliação do conjunto de ações é satisfação do cliente. Segundo os entrevistados a satisfação está ligada ao relacionamento com o banco e reflete o resultado de um conjunto de ações como patrocínio, venda direta - por meio dos gerentes -, marketing direto e promoções de vendas.

Por último, o CPM que, não é fácil de ser aplicado às diferentes ações de comunicação.

(...) eu sei quanto custa para atingir 1.000 pessoas pela revista, pela TV ou pelo patrocínio, eu sei também quanto custa para atingir 1.000 com Twitter ou com uma coisa no meu Facebook, a gente já está fazendo isso, mas a gente está fazendo isso, por enquanto para o nosso aculturamento interno, porque são coisas ainda muito desproporcionais.

Outra ressalva proposta por um entrevistado é o cuidado com o excesso de métricas. Apesar de importantes para a garantia do efetivo alcance dos objetivos e aprimoramento contínuo da estratégia, as empresas devem evitar serem reféns das métricas. Caso contrário, os profissionais de comunicação correm o risco de uma orientação excessiva para a medição dos resultados, em detrimento da criatividade e inovação necessárias às ações de comunicação. Conforme um dos entrevistados, 
A campanha tem que ser criativa, ela tem que emocionar, ou ela tem que divertir, ou ela tem que..., ela tem que tocar as pessoas, para despertar o interesse nelas (...) Então em qualquer circunstância não se pode abrir mão da criatividade, da pertinência e da ousadia na comunicação, não se pode. E este é o equilíbrio (...) Eu jamais imaginaria um controlador, um controler plástico, em cima de marketing, ele iria acabar com marketing.

Foi indicada também a dificuldade de medir o efeito isolado de algumas ações sobre resultados amplos, como, conhecimento da marca. Para minimizar esta dificuldade, uma sugestão indicada por um entrevistado é que quando possível, o plano de comunicação seja implantado em ondas, o que permitiria avaliar o impacto de cada ação isolada.

\subsubsection{Modelo de adoção de métricas de avaliação dos resultados das ações de comunicação offline e online apontadas como as mais importantes}

A análise das informações levantadas na fundamentação teórica foi combinada à análise do conteúdo das entrevistas a fim de atingir o objetivo de propor um modelo de adoção de métricas de avaliação dos resultados das ações de comunicação offline e online apontadas como as mais importantes.

O setor estudado apresenta uma particularidade: a posse de bancos de dados de seus clientes com informações demográficas - idade, renda, ciclo de vida do consumidor, etc. - bem como dados comportamentais e de consumo. Esses bancos de dados são criados, em alguns casos, antes mesmo da abertura de conta, e são continuamente atualizados à medida que os correntistas contratam e utilizam os serviços oferecidos. Essa particularidade viabiliza adoção de marketing de relacionamento com mais precisão do que em outros setores e pode estar associada à importância atribuída a esta ferramenta por toda a amostra.

Outras particularidades da amostra e do setor estudado são:

i) forte orientação para ações de comunicação pertinentes ao marketing de relacionamento e, consequentemente à adoção de métricas relativas a esta ação;

ii) investimentos em propaganda com foco em mídias de massa;

iii) presença na internet, mas em diferentes níveis de esforços. 
A propaganda - offline e online - e o marketing de relacionamento destacam-se dentre as ações de comunicação de maior importância. O marketing de relacionamento, apoiado pelo marketing direto, caracteriza-se por ser uma das ações de comunicação relevantes ao setor estudado.

A análise das ações de comunicação offline e online mais importantes, seus públicosalvo e as respectivas métricas adotadas para sua avaliação, permitiram desenvolver o modelo apresentado na Figura 22. Essa figura apresenta as ferramentas de comunicação citadas por, pelo menos quatro entrevistados e destaca seus respectivos públicos-alvo: massa, segmentos ou indivíduo, bem como as métricas adotadas para cada ação.

As ferramentas de comunicação em círculos negros foram citadas por representantes de toda a amostra entrevistada e são as mais importantes. As ferramentas em círculos brancos foram mencionadas por entrevistados de quatro instituições. A localização dos círculos em relação aos públicos-alvo - massa, segmentos e indivíduo - indica a quem são direcionadas as ferramentas de comunicação.

A propaganda offline e online tem como foco a massa e seus principais objetivos são promover a marca, os produtos e venda. As formas mais significativas de avaliação de propaganda continuam sendo métricas tradicionais como vendas, awareness, recall, top of mind, auditoria de imagem e CPM. 


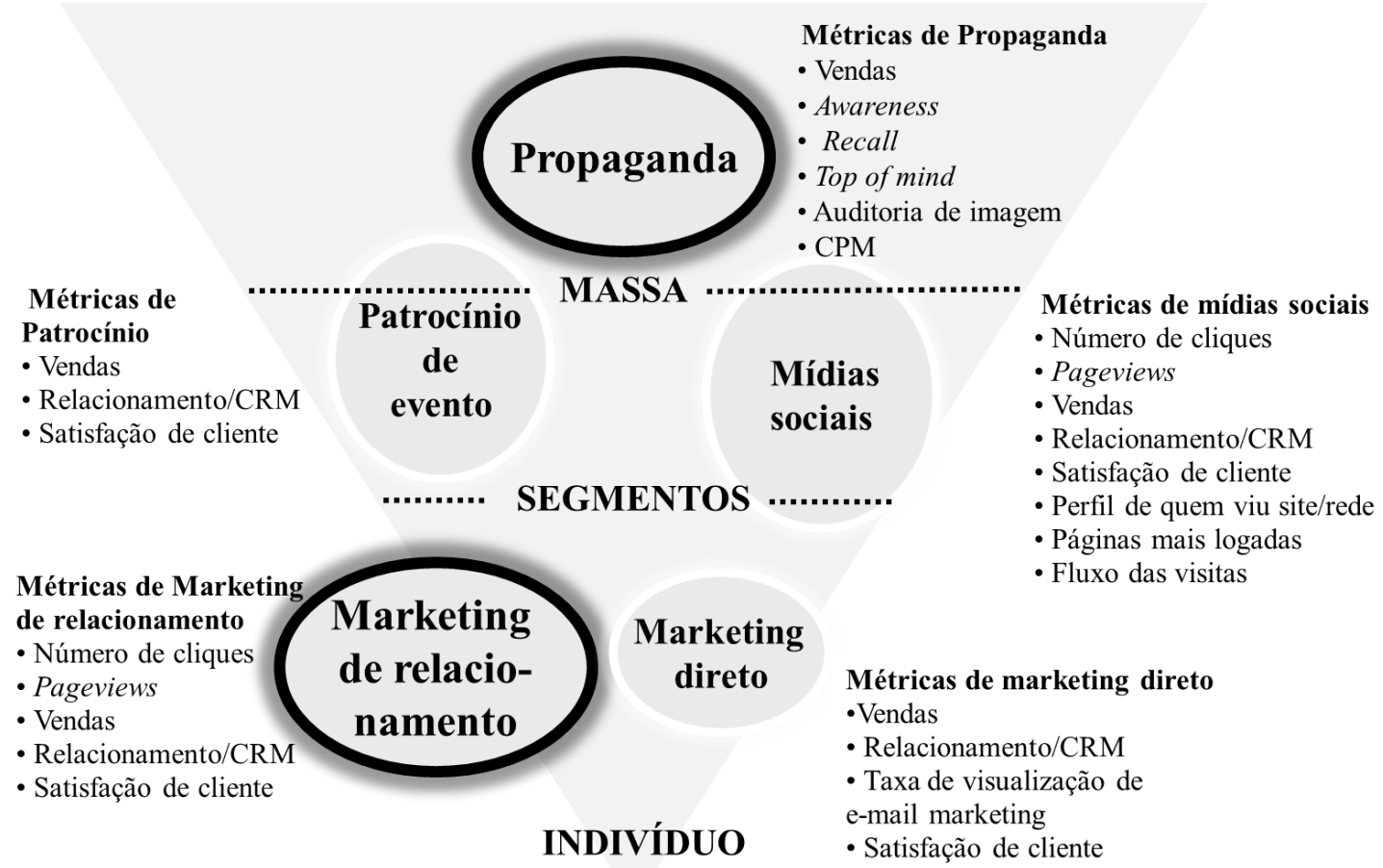

Figura 22 - Modelo de adoção de métricas de avaliação dos resultados das ações de comunicação offline e online apontadas como mais importantes e suas respectivas métricas

FONTE: Elaborado pela autora

Apesar de a propaganda online permitir uma interação um a um e atingir segmentos, seu foco permanece sendo a massa. Os resultados da propaganda online são, no entanto, difíceis de serem mensurados na dimensão do indivíduo, exceto no caso de propagandas online em que é possível identificar a reação de cada indivíduo por clique, pageviews ou venda.

De acordo com o modelo da Figura 22, a próxima ferramenta a ser analisada é o patrocínio. Adotado para ações de massa e para segmentos específicos como prospects e clientes, os objetivos quando se adota esta ferramenta são promoção da marca, seus produtos e vendas. Em relação à avaliação de patrocínios, a amostra entrevistada mencionou avaliar ações de patrocínio por meio de vendas, relacionamento/CRM e satisfação de cliente, sendo esta última métrica inerente a relacionamento. As métricas reforçam a orientação que o setor estudado dedica ao marketing de relacionamento. 
A ferramenta de mídias sociais é a mais versátil dentre as citadas por atingir as dimensões de massa, segmentos e indivíduos. Essa ação oferece a vantagem de mensurações mais precisas sobre o comportamento do público. As formas de avaliação de resultados combinam métricas comuns ao mundo virtual como número de cliques e pageviews com vendas, relacionamento e satisfação.

Dentre as ações com foco no indivíduo, as métricas mais adotadas para a avaliação de ações de marketing de relacionamento são relacionadas a ações online, seguidas de vendas, relacionamento e satisfação do cliente. Esse resultado pode ser relacionado ao aumento da importância que a internet tem para as ações de relacionamento com clientes e prospects ou à disseminação de mensuração das ações online.

Em relação ao marketing direto, ação com foco no indivíduo, as métricas mais adotadas são semelhantes às de marketing de relacionamento, com a liderança da métrica vendas, seguida de relacionamento/CRM e satisfação de cliente para ações offline.

O modelo apresentado objetiva apontar as ações de comunicação para diferentes públicos e suas respectivas métricas junto à amostra estudada. Em seguida serão apresentadas as considerações finais desse estudo. 


\section{CONSIDERAÇÕES FINAIS}

A presente pesquisa buscou contribuir para um melhor entendimento de como empresas lidam com a diversidade de ações de comunicação offline e online e avaliam esses investimentos.

As conclusões indicam haver diferentes caminhos sendo trilhados, não havendo uma convergência para um único. Ficou clara a importância da diversificação de investimentos de comunicação de massa, em segmentos e nos indivíduos.

Os resultados também evidenciam a crescente importância dos investimentos em ações de comunicação online, mas que ainda estão longe de representar um substituto à tradicional propaganda de massa. Desde que surgiram, esses investimentos têm métricas para avaliação dos resultados atingidos que vêm sendo amplamente adotadas pela amostra.

Há uma variedade de métricas offline e online. As empresas vêm atribuindo crescente importância a sua adoção e estão se organizando e investindo cada vez mais em formas de apuração dos resultados gerados por investimentos em comunicação desta natureza, mas ainda não é feita uma comparação entre as métricas de avaliação de ferramentas offline com as métricas de apuração dos resultados de comunicação online.

Apesar da amostra não ter demonstrado a incorporação do conceito de LTV, consagrada métrica de avaliação de marketing de relacionamento, há indícios de que caminhem neste sentido.

Há bancos que buscam avaliar o ROI de cada ação em busca da garantia da identificação do retorno de cada investimento para avaliar as ações tomadas e aprimorar as futuras decisões.

Além dos objetivos de identificação das ações de comunicação de maior importância, das respectivas métricas de avaliação de resultados destas ações e da identificação de ser feita algum tipo de comparação entre as métricas das ações offline e online, as 
entrevistas permitiram identificar alguns cuidados para o aprimoramento e efetividade do que seria um aculturamento para a prática de avaliação de investimentos.

Um caminho a ser seguido para garantir a efetividade de uma cultura orientada para a avaliação dos resultados é incorporar as métricas aos objetivos de desempenho dos profissionais envolvidos nas decisões de investimentos em comunicação.

No entanto, apesar da importância das métricas é relevante não perder a perspectiva de que estas sejam adotadas sem preterir a criatividade e inovação necessárias às ações de comunicação, sobretudo a propaganda.

\subsection{Limitações}

Os resultados desta pesquisa são restritos a uma amostra formada por bancos que investem numa variedade de ações de comunicação, não devendo ser estendidos para todos os bancos, nem a outros setores.

O critério de seleção dos entrevistados foi seu envolvimento direto com as decisões de comunicação. Tendo em vista a quantidade de decisões, em algumas instituições foram entrevistados profissionais com orientação maior para algumas ações específicas como relacionamento com clientes ou marca. Alguns entrevistados são especialistas em áreas como CRM e apresentaram uma visão mais inclinada para ações e métricas específicas, tais como ações de marketing direto e relacionamento.

\subsection{Recomendações para futuras pesquisas}

Sugere-se que sejam desenvolvidos estudos em outros setores para confirmar se a sistematização das ações de comunicação offline e online e das métricas de sua avaliação poderiam ser estendidas para outros setores com foco em marketing de relacionamento, como cartões de crédito e telefonia. 
Uma oportunidade para pesquisa é avaliar o impacto da rede de agências na decisão de escolha do banco, uma vez que os correntistas aumentam cada vez mais o uso da internet para a movimentação da sua conta e que todos os bancos adotam internet banking e investem em mídia social para ampliar sua presença.

(...) A questão da mídia social a mesma coisa, para tentar compensar um pouco esta falta da lojinha com a placa na rua (agência) (...)

Outra questão apontada no estudo e que poderia ser explorada em pesquisa futuras, é o comprometimento das agências de publicidade com a adoção das métricas de avaliação dos investimentos em comunicação. Tendo em vista sua remuneração ser baseada no montante de mídia contratado pelo anunciante, é natural que estimulem a contratação de propaganda em mídias que lhe confiram ganhos vantajosos.

Uma vez que os correntistas vêm intensificando o uso da internet para a movimentação da sua conta e que todos os bancos adotam internet banking e investem em mídias sociais para ampliar sua presença, uma possível pesquisa seria avaliar o impacto da capilaridade da rede de agências na decisão de contratação de um banco.

Por último, uma vez que alguns entrevistados apontaram a importância do alinhamento entre estratégia e a adoção de métricas, outra oportunidade de estudo é avaliar a relação entre o que as empresas indicam como objetivos de comunicação na fase de planejamento e a existência de processos para sua medição. 


\section{REFERÊNCIAS}

AAKER, D. A. Building strong brands. New York: Free Press, 1996a.

- Measuring brand equity across products and markets. California Management Review. v. 38, n. 3, p. 102-120, spring 1996 b.

- Marcas: brand equity: gerenciando o valor da marca. 2. ed São Paulo: Negócio, 1998.

; BIEL, A. L. Brand equity and advertising: advertising's role in building strong brands. Hillsdale, NJ: Lawrence Erlbaum, 1993.

; JACOBSON, R. The financial information content of perceived quality. Journal of Marketing Research,. v. 31, n. 2, p.191-201, May 1994.

; JOACHIMSTHALER, E. Brand leadership. New York: Free Press, 2000.

et al. Pesquisa de marketing. São Paulo: Atlas, 2001.

ABEMD - Associação Brasileira de Marketing Direto. Indicadores 2009 e $1^{\circ}$ semestre 2010.

Disponível

em:

$<$ http://www.abemd.org.br/interno/indicadoresabemd2009e1osemestre2010-

coletiva.pdf>. Acesso em: 10/08/2011.

ACCENTURE. Guia de melhores práticas de ROI em marketing. 2009. Pesquisa interna.

ADVERTISING AGE. 10 Trends that are shaping global media consumption. 2010. Disponível em: < http://adage.com/globalnews/article?article_id=147470consuming in earnest>. Acesso em: 20/10/2011.

ALMEIDA, A. L. S. de. O conhecimento e a importância das métricas de marketing para gestores de médias e grandes empresas brasileiras. Porto Alegre, 2007. Dissertação (Mestrado em Administração e Negócios) - Faculdade de Administração, Contabilidade e Economia da Pontifícia Universidade Católica do Rio Grande do Sul.

ALVAREZ, Francisco J. S. M. Trade marketing: a conquista do consumidor no ponto de venda. São Paulo: Saraiva, 2008.

AMA - American Marketing Association, 1989. Disponível em: <http://www.marketingpower.com/Community/ARC/Pages/Additional/Definition/defau 1t.aspx?sq=marketing+definition>. Acesso em: 21/03/2010.

AMBLER, T. Marketing and the bottom line: the new metrics of corporate wealth. London: Prentice Hall/Financial Times, 2000a.

$2000 \mathrm{~b}$

Marketing metrics. Business Strategy Review. v. 11, n. 2, p. 59-67, summer 
AMBLER, T.; KOKKINAKI, F. Measures of marketing success. Journal of Marketing Management. v. 13, n. 7, p. 665-678, October 1997.

AMBLER, T. et al. Assessing marketing performance: reasons for metrics selection. Journal of Marketing Management. v. 20, n. 3/4, p. 475-99, 2004.

AMBLER, T.; ROBERTS, J. H. Assessing marketing performance: don't settle for a silver metric. Journal of Marketing Management. v. 24, n. 7/8, p. 733-750, September 2008.

ANDERSON, R. Personal selling and sales management in the new millennium. Journal of Personal Selling \& Sales Management. v. 16, n. 4, p.17-32, fall 1996.

ANDERSON, E. W; SULLIVAN, M. W. The antecedents and consequences of customer satisfaction for firms. Marketing Science, v. 12, n. 2, p. 125-143, 1993.

ANG, L. Community relationship management and social media. Journal of Database Marketing \& Customer Strategy Management. v. 18, Issue 1, p. 31-38, Mar. 2011.

BACEN - Banco Central do Brasil. Relatório 50 Maiores bancos e o Sistema Financeiro Nacional. Disponível em: 〈http://www4.bcb.gov.br/top50/port/top50.asp> . Acesso em: 01/06/2011.

BAKER, M. J. Administração de marketing. Rio de Janeiro: Elsevier. 2005.

BALASUBRAMANIAN, S. K. Beyond advertising and publicity: hybrid messages and public policy issues. Journal of Advertising. v. 23, Issue 4, p. 29-46, Dec. 94.

BANCO DO BRASIL. Disponível em: <http://www.bb.com.br/portalbb/home23,116,116,1,1,1,1.bb $>$. Acesso em: 15/08/2011.

BANCO DO BRASIL. 2011. Esportes. Disponível em: <http://www.facebook.com/BBnosEsportes >. Acesso em: 15/08/2011.

BANCO CULTURAL. 100 maiores incentivadores nas Leis Rouanet (8.313/91) e Audiovisual (8.685/93) de 2006. [2011]. Disponível em: <http://www.bancocultural.com.br/?option=com_content\&task=view\&id=666\&Itemid= 369> Acesso em 17/08/2011.

BANCO VOTORANTIM. Disponível em: <http://www.bancovotorantim.com.br/web/site/bv/para_voce >. Acesso em 20/10/2011.

BARDIN, L. Análise de conteúdo. 4. ed. Lisboa: Edições 70, 2007.

BARNETT, M. True measure of performance is bottom line. MarketingWeek. 16 September 2010. Disponível em: <http://www.marketingweek.co.uk/trends/truemeasure-of-performance-is-bottom-line/3018205.article?sm=3018205>. Acesso em: $15 / 06 / 2011$.

BARWISE, P. Brand equity: snark or boojum? International Journal of Research in Marketing. v. 10, n. 1, p. 93-104, March 1993. 
BARWISE, P.; FARLEY, J. U. Marketing metrics: status of six metrics in five countries. European Management Journal. v. 22, n. 3, p. 257-262, June 2004.

BARWISE, P.; STRONG, C. Permission-based mobile advertising. Journal of Interactive Marketing. v. 16, n. 1, p.14-24, winter 2002.

BATISTA, F. P.S. Gestão de marcas por meio das redes sociais: um estudo sobre a utilização do facebook. São Paulo, 2011. Dissertação (Mestrado em Administração) Faculdade de Economia, Administração e Contabilidade, Universidade de São Paulo.

BATOCHIO, R. Momento de ouro. Projeto Inter-Meios. Meio \& Mensagem. São Paulo, 30/5/2011.

BELCH, G. E.; BELCH, M. A. Propaganda e promoção. 7. ed. São Paulo: McGrawHill, 2008.

BERRY, L. L. Relationship marketing of services - growing interest, emerging perspectives. Journal of the Academy of Marketing Science. v. 23, n. 4, p. 236-45, 1995.

BIANCO, A. The vanishing mass market. BusinessWeek. p. 61-68. July 2004. Disponível em: <http://www.businessweek.com/magazine/content/04_28/b3891001_mz001.htm>.

Acesso em: 13/09/2011.

BLACKWELL, R. et al. Comportamento do consumidor. São Paulo: Pioneira Thompson Learning, 2005.

BLATTBERG, R.; NESLIN, S. A. Sales promotion concepts, methods, and strategies. Englewood Cliffs, NJ: Prentice Hall, 1990, apud SRINIVASAN, S. et al. Mind-set metrics in market response models: an integrative approach. Journal of Marketing Research. v. 47, p. 672-684, August 2010.

BLESSA, R. Merchandising no ponto-de-venda. São Paulo: Atlas, 2005.

BONOMA, T. V.; CLARK, B. H. Marketing performance assessment. Boston, MA: Harvard Business School Press, 1988.

BORTOLI, L. V.; CAMPOMAR, M. C. Da comunicação boca a boca para o marketing viral. In SEMINÁRIOS EM ADMINISTRAÇÃO - SemeAD, 12., 2009, São Paulo. Anais... São Paulo: FEA/USP, 2009.

BOSCHAN, P. Demand analysis: a study in econometrics. Journal of Marketing. v. 18, n. 2, p. 211-212, October 1953.

BRADESCO. Disponível em: 〈http://www.bradesco.com.br/> . Acesso em: 16/08/2011.

BRADY, D. Making marketing measure up. Business Week. December 13th, 2004. Disponível

em: 
$<$ http://www.businessweek.com/magazine/content/04_50/b3912109.htm>. Acesso em: $10 / 02 / 2010$.

BRESSOUD, E. et al. The product well placed. Journal of Advertising Research. v. 50, n. 4, p.374-385, December 2010.

BROADBENT S.; FRY T. Adstock modelling for the long term. Journal of the Market Research Society. v. 37, p. 385-403, 1995.

BRONNENBERG, B. et al. Do digital video recorders influence sales? Journal of Marketing Research. v. 47, n. 6, p. 998-1010, 2010.

BROWN, D. B. A practical procedure for media selection. Journal of Marketing Research. v. 4, n. 3, p. 262-269, August 1967.

BUZZELL, R. D. et al. Market share - a key to profitability. Harvard Business Review. v. 53, n. 1, p. -106, January/February 1975.

BUZZELL, R. D.; CHUSSIL, M. J. Managing for tomorrow. Sloan Management Review. v. 26, p. 3-14, summer 1985.

BUZZELL, R. D.; GALE, B. The PIMS principles: linking strategy to performance. New York: Free Press, 1987.

CAIXA ECONÔMICA FEDERAL. Disponível em: 〈http://www.caixa.gov.br>. Acesso em: 20/08/2011.

CAMERON, G. T. Does publicity outperform advertising? An experimental test of the third-party endorsement. Journal of Public Relations Research. v. 6, n. 3, p. 185-208, 1994.

CAMERON, N. Understanding sponsorship and its measurement implications. Journal of Sponsorship. v. 2, n. 2, p. 131-139, February 2009.

CAMPOMAR, M.; IKEDA A. A. O planejamento de marketing e a confecção de planos: dos conceitos a um novo modelo. São Paulo: Saraiva, 2006.

CARTON, R. B.; HOFER, C. W. Measuring organizational performance: metrics for entrepreneurship and strategic management research. Cheltenham: Edward Elgar, 2006.

CHADE, J. 97 países têm mais de um celular por pessoa. O Estado de São Paulo. 3/08/2011. Disponível em: <http://blogs.estadao.com.br/jt-seu-bolso/97-paises-ja-temmais-de-um-celular-por-habitante/>. Acesso em: 20/10/2011.

CHURCHILL, G. A., PETER, J. P. Marketing: criando valor para o cliente. 2. edição. São Paulo: Prentice Hall, 2003.

CITIBANK. 
CLARK, L.; DIRKSEN, C. J. Journal of Marketing. v. 16, n. 2, October 1951.

CLARK, B. Marketing performance measure history and interrelationship. Journal of Marketing Management. v. 15, p. 711-732, 1999.

CLOSE, A. G. et al. Engaging the consumer through event marketing: linking attendees with the sponsor, community, and brand. Journal of Advertising Research. v. 46, n. 4, p. 420-433, December 2006.

COBRA, M. Marketing de serviço financeiro. São Paulo: Marcos Cobra/Desenvolvimento Empresarial, 2000.

COLLEY, R. H. Defining advertising goals for measured advertising results. New York: Association of National Advertisers, 1961.

COLLIANDER, J.; DAHLÉN, M. Following the fashionable friend: the power of social media weighing publicity effectiveness of blogs versus online magazines. Journal of Advertising Research. v. 51, n. 1, p. 313-320, March 2011.

COLLIS, J.; HUSSEY, R. Pesquisa em administração: um guia prático para alunos de graduação e pós-graduação. 2. ed. Porto Alegre: Bookman, 2005.

CONCEIÇÃO, A. C. Nem on nem off: futuro do mídia é ser generalista. Especial Profissional de Mídia. Meio \& Mensagem. 20 junho 2011.

COOK, W. A. Plenty amidst scarcity. Journal of Advertising Research, v. 30, n. 1, p. 36-38, February/March 1990.

CORNWELL, T. et al. The relationship between major-league sports' official sponsorship announcements and the stock prices of sponsoring firms. Journal of the Academy of Marketing Science. v. 33, n. 4, p. 401-412, 2005

CORRÊA, R. Uma análise da propaganda bancária do mercado brasileiro. In LAS CASAS, Alexandre Luzzi (Org.). Marketing bancário. São Paulo: Saint Paul, 2007. Cap 7, p. 217-237.

COSTELlA, A. F. Comunicação - do grito ao satélite. Campos do Jordão: Mantiqueira, 2001. apud Panorama da Comunicação e Telecomunicações no Brasil. Disponível em: $<$ http://www.ipea.gov.br/portal/images/stories/PDFs/Panorama_da_Comunicao_e_das Telecomunicaes_no_Brasil___Volume_3.pdf>. Acesso em: 08/09/2011.

COUGHLAN, A. T. et al. Canais de marketing e distribuição. 6. ed. Porto Alegre: Bookman, 2002.

COWLEY, E.; BARRON, C. When product placement goes wrong. Journal of Advertising. v. 37, n. 1, p. 89-98, spring 2008.

CRESWELL, J. W. Projeto de pesquisa: método qualitativo, quantitativo e misto. 2. ed. Porto Alegre: Artmed, 2007. 
CUCOLO, E. Internet ultrapassa caixa eletrônico e lidera transações bancárias, diz BC. Folha de S.Paulo, 05/07/2010. Disponível em: $<$ http://www1.folha.uol.com.br/mercado/762025-internet-ultrapassa-caixa-eletronico-elidera-transacoes-bancarias-diz-bc.shtml>. Acesso em: 10/06/2011.

DAY, G. S.; WENSLEY, R. Assessing advantage: a framework for diagnosing competitive superiority. Journal of Marketing. v. 52, p. 79-89, April 1988.

DAY, G. S. Closing the marketing capabilities gap. Journal of Marketing. v. 75, Issue 4, p. 183-195, July 2011.

DEANE et al. Sport sponsoship and brand personality - The Ryder Cup Team and IBM. International of Journal of Sports Marketing \& Sponsoship, v. 5, n.3, p. 193208, 2003.

DEBRUYNE, M.; HUBBARD. K. Marketing metrics. Report Marketing Science Institute. n. 00-119, 2000.

DELOITTE. Marketing in 3D. 2008. Disponível em: $<$ http://www.deloitte.com/assets/Dcom-

Sweden/Local\%20Assets/Documents/se_marketing_in_3d_060208.pdf >. Acesso em: 02/05/2011.

DESHPANDÉ, R. et al. Corporate culture customer orientation, and innovativeness in Japanese firms: a quadrad analysis. Journal of Marketing. v. 57, n. 1. p. 23-37, January 1993.

DESHPANDÉ, R.; FARLEY, J. U. Measuring market orientation: generalization and synthesis. Journal of Market Focused Management. v. 2, p. 212-232, September 1998.

DESS, G. G.; ROBINSON, R. B. Measuring organizational performance in the absence of objective measures: the case of the privately-held firm and conglomerate business unit. Strategic Management Journal. v. 5, p. 265-273, 1984.

DIAS, S. R. (Org.). Professores do Departamento de Mercadologia da FGV - EAESP e Convidados. Gestão de marketing. São Paulo: Saraiva, 2003.

DICKINSON, R.; ROTHBERG, R. R. Techniques of profitability analysis (Book analysis). Journal of Retailing. v. 49, n. 1, p.79, spring 1973.

DICHTER, E. How word-of-mouth advertising works. Harvard Business Review, v. 44, n. 6, p. 147-166, November/December 1966.

DOYLE, P. Value-based marketing: marketing strategies for corporate growth and shareholder value. New Jersey: John Wiley and Sons, 2000.

DRENGNER J. et al. Does flow influence the brand image in event marketing? Journal of Advertising Research. v. 48, n. 1, p. 138-147, March 2008. 
DUNCAN, T. R. IMC: Using Advertising Research: Theory and Practice. Boston: McGraw-Hill.

DUNNINGHAM, A. O poder das redes sociais na tomada de decisão. O Globo. 07/07/2011. Disponível em: <http://oglobo.globo.com/blogs/mercadodigital/posts/2011/07/07/o-poder-das-redessociais-na-tomada-de-decisao-390801.asp >. Acesso em: 25/10/2011.

EAST, R. et al. The NPS and the ACSI. International Journal of Market Research. v. 53, n. 3, p. 327-346, 2011.

EMAIL MARKETING METRICS REPORT. June 2009. Disponível em < http://www.mailermailer.com/resources/metrics/index.rwp>. Acesso em 08/09/2011.

ÉPOCA. Rio de Janeiro: Globo, n. 628, 31/05/2010.

EWING, M. T. Integrated marketing communications measurement and evaluation. Journal of Marketing Communications, v.15, n. 2-3, p. 103-117, april-july 2009.

FACEBOOK. $\quad$ Estatísticas. 2011. Disponível em: <http://www.facebook.com/press/info.php?statistics >. Acesso em: 09/11/2011.

FAN, M. et al. Selling or advertising: strategies for providing digital media online. Journal of Management Information Systems. v. 24, n. 3, p. 143-166, winter $2007 / 2008$

FALKE INFORMATION. Evolução do setor brasileiro de mídia e publicidade. Relatório Setorial. São Paulo, março 2011.

FARRELL, K.; FRAME, W. The value of Olympic sponsorships: who is capturing the gold? Journal of Market- Focused Management. v. 2, n. 2, p. 171-182, 1997.

FARRIS, P. W. et al. Métricas de marketing: mais de 50 métricas que todo executivo deve dominar. Porto Alegre: Bookman, 2007.

FEBRABAN. 2010. Disponível em: <http://www.febraban.org.br/Febraban.asp?id_pagina=234>. Acesso em: 20/11/2011.

FEICK, L. F.; PRICE, L. L. The marketing maven: a diffuser of marketplace information. Journal of Marketing. v. 51, p. 83-97, 1987.

FEDER, R. A. How to measure marketing performance. Harvard Business Review. v. 43, n. 3, p. 132-142, 1965.

FOROOTAN, D. Google Analytics offer marketers plenty of ways to measure response. B To B. v. 93, n. 13, p. 22, 29/09/2008.

FORNELL, C. et al. The American customer satisfaction index: nature. Purpose and findings. Journal of Marketing. v. 60, n. 4, p. 7-18, 1996. 
FREITAG, A. How to measure what we do. Public Relations Quarterly. v. 43, n. 2, p. 42-47, summer 1998.

GLADWELL, M. The tipping point: the little things can make a big difference. Boston, NY, London: Little Brown, 2000.

GODOI, C. K.; MATTOS, P. L. C. L. Entrevista qualitativa: instrumento de pesquisa e evento diálogo. In: GODOI, C. K.; BANDEIRA-DE-MELLO, R.; SILVA, A. B. (Org.). Pesquisa qualitativa em estudos organizacionais: paradigmas, estratégias e métodos. São Paulo: Saraiva, 2006.

Perspectivas da análise do discurso nos estudos organizacionais. In GODOI, C.K.; BANDEIRA-DE-MELlO, R.; SILVA, A. B. (Org.). Pesquisa qualitativa em estudos organizacionais: paradigmas, estratégias e métodos. São Paulo: Saraiva, 2006.

GODOY, A. S. Introdução à pesquisa qualitativa e suas possibilidades. Revista de Administração de Empresas. São Paulo, v. 12, n. 3, p. 75-90, julho/setembro 1995.

GOOD, B. Planning perfect events. Research Magazine. v. 33, n. 8, p. 57-58, August 2010.

GOODMAN, S. Techniques of profitability analysis. New York: Interscience Division, John Wiley \& Sons, 1970 apud DICKINSON, R.; ROTHBERG, R. R. Techniques of profitability analysis (Book analysis). Journal of Retailing. v. 49, n. 1, p.79, spring 1973.

GOOGLE ANALYTICS. 2011. Disponível em: <http://www.google.com/analytics/>. Acesso em: 20/11/2011.

GOOGLE TRENDS. 2011. Disponível em: 〈http://www.google.com/trends $>$. Acesso em: 20/11/2011.

GORDON, I. H. Relationship marketing: new strategies, techniques and technologies to win the customer you want and feet them over. Toronto, Canada: John Wiley \& Sons, 1998.

GREENE, M. CARD, D. US DVR Forecast, 2007 to 2012. Forrester Research. December 28, 2007 apud BRONNENBERG, B. et al. Do digital video recorders influence sales? Journal of Marketing Research. v. 47, n. 6, p. 998-1010, 2010.

GRÖNROOS, C. From marketing mix to relationship marketing: towards a paradigm shift in marketing. Management Decision. v. 32, n. 2, p. 4-21, 1994.

GRUNIG, J. E.; GRUNIG, L. A. The relationship between public relations and marketing in excellent organizations: evidence from the IABC study. Journal of Marketing Communications. v. 4, n. 3, p. 141-162, 1998.

GUISSONI, L. A.; NEVES, M. F. Comunicação integrada de marketing baseada em valor. São Paulo: Atlas, 2011. 
GUMMESSON, E. Marketing de relacionamento total: gerenciamento de marketing, estratégia de relacionamento e abordagens de CRM para a economia de rede. 2. ed. Porto Alegre: Bookman, 2005.

GUPTA, S.; LEHMANN, D. R. Customer lifetime value and firm valuation. Journal of Relationship Marketing. v. 5, n. 2\&3, p. 87-110, 2006.

GUPTA, S. et al. Social media. Harvard Business Publishing. 9-510-095. 4 October 2011.

HALLAHAN, K. Content class as a contextual cue in the cognitive processing of publicity versus advertising. Journal of Public Relations Research. v. 11, n. 4, p. 293$321,1999$.

HAMPP, A. Gap to scrap new logo, return to old design. Advertising Age. 2010. Disponível em: <http://adage.com/article/news/gap-scrap-logo-return-design/146417/>. Acesso em: 10/09/2011.

HAGHIRIAN, P. Advertising goes mobile: explaining attitude toward m-advertising. AMA Winter Educators Conference Proceedings, v. 16, p. 260-261, 16 Jan. 2005.

HANSEN, F.; SCOTWIN, L. An experimental enquiry into sponsoring: what effects can be measured? Marketing and Research Today. p. 173-181, August 1995.

HERSCH, W. S. Leveraging The Benefits Of Event Marketing. National Underwriter Life \& Health Financial Services, v. 111, n. 16, 23/4//2007.

HESKETT, J. et al. Putting the service-profit chain to work. Harvard Business Review. v. 72, n. 2, p. 164-170, March/April 1994.

HSBC. Disponível em: <http://www.hsbc.com.br/1/2/portal/pt/pagina-inicial/hsbc-nobrasil>. Acesso em: 14/08/2011.

HUNT, T.; GRUNIG, J. E. Public relations techniques. Fort Worth, TX: Hartcourt Brace College Publishers, 1993 apud LODA, M. et al. Sequence matters: a more effective way to use advertising and publicity. Journal of Advertising Research. v. 45, Issue 4, p. 362-372, Dec. 2005.

HUTT, M.; SPEH, T. B2B: gestão de marketing em mercados industriais e organizacionais. São Paulo: Cengage, 2010.

IBOPE. Anunciantes 30 maiores. 2006 a 2010. Disponível em: < HYPERLINK "http://www.almanaqueibope.com.br/asp/busca_docInfo.asp" http://www.almanaqueib ope.com.br/asp/busca_docInfo.asp .>. Acesso em: 30/5/2011.

Mercado Financeiro em alta. 19/06/2007. Disponível em < http://www.ibope.com.br/calandraWeb/servlet/CalandraRedirect?temp=5\&proj=PortalI

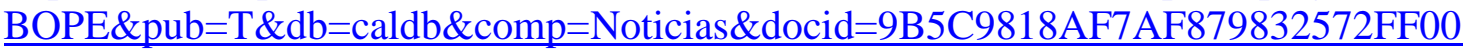
835F29.> Acesso em 28/5/2011. 
- Ferramentas de avaliação de resdes sociais. Disponível em < http://www.ibope.com.br/calandraWeb/servlet/CalandraRedirect?temp=5\&proj=PortalI BOPE\&pub=T\&db=caldb\&comp=IBOPE+M\%EDdia\&docid=F19433C28889CDB583 $\underline{257722004 \mathrm{D} 854 \mathrm{~F}}>$. Acesso em 15/10/2011.

IDC. Expanding the digital universe: a forecast of worldwide information growth through 2010. White paper, IDC apud DAY, G. Closing the marketing capabilities gap. Journal of Marketing. v. 75, n. 4, p.183-195, July 2011.

IKEDA, A. A.; CRESCITELLI, E. O efeito potencial da comunicação integrada de marketing. Revista Marketing, maio 2003.

INTERBRAND. Disponível em: 〈http://www.interbrand.com/en/default.aspx $>$. Acesso em: 10/07/2011.

INTERBRAND. As 25 marcas mais valiosas do Brasil. 2011. Disponível em: $<$ http://issuu.com/interbrand/docs/marcas_brasileiras_mais_valiosas_2011-

2? viewMode=presentation $\&$ mode $=$ embed $>$. Acesso em: 6/6/2011.

INTER MEIOS. Relatórios de investimento em comunicação 2006-2011. 2011. Disponível em: <http://www.projetointermeios.com.br/relatorios-de-investimento>. Acesso em: 16/09/2011.

IRWIN, R.; SUTTON, W. Sport sponsorship objectives: an analysis to their relative importance for major corporate sponsors. European Journal for Sport Management. v. 1, n. 2, p. 93-102, 1994.

ITAÚ UNIBANCO HOLDING S.A. Informações com investidores. Disponível em: $<$ http://ww13.itau.com.br/portalri/default.aspx?secao=1\&idioma=port\&aspxautodetectc ookiesupport=1>. Acesso em 16/08/2011.

ITU - International Telecommunication Union. Measuring Information Society, 2011. Disponível em: <http://www.itu.int/ITUD/ict/publications/idi/2011/Material/MIS_2011_without_annex_5.pdf $>$. Acesso em: 20/11/2011.

IVC. Relatório anual de circulação. [2011]. Disponível em: <http://www.ivc.org.br/ijeweb/scripts/ijeweb.cgi/actpublica?CodF=0\&rbOrdem=Public ação\&rbAgrupa=Natureza\&rbPublica=PrincipalSuplemento\&rbTipoPub=Todos\&rbSta tus=A\&rdFormato=Phttp://ww13.itau.com.br/portalri/default.aspx $?$ secao $=1 \&$ idioma=po rt\&aspxautodetectcookiesupport=1 > . Acesso em: 19/09/2011.

JACOBSON, R. Distinguishing among competing theories of the market share effect. Journal of Marketing. v. 52, n. 4, p.68-80, October 1988.

JAWORSKI, B.; KOHLI, A. Market Orientation: Antecedents and Consequences. Journal Of Marketing, v. 57, p. 53-70, July 1993.

JENSEN, M. B. Characteristics of B2B adoption and planning of online marketing communications. Journal of Targeting, Measurement and Analysis for Marketing. v. 14, p. 357-368, 2006. 
JENSEN, J. A.; HSU, A. Does sponsorship pay off? An examination of the relationship between investment in sponsorship and business performance. International Journal Of Sports Marketing \& Sponsorship. v. 12, n. 4, p. 352-364, July 2011.

JUNG, K.; ROBINSON, B. Measuring the return on your communications investments. Journal of Integrated Marketing Communications, p. 32-36, 2005.

KAPLAN, R. S.; NORTON, D. P. The balanced scorecard - measures that drive performance. Harvard Business Review. p. 71-79, Jan./Feb. 1992.

KEEGAN et al., 1992. Marketing. Englewood Cliffs, NJ: Prentice - Hall.

KELLER, K. L. Conceptualizing, measuring, and managing customer-based equity. Journal of Marketing. v. 57, n. 1, p. 1-22, January 1993.

. Strategic brand management: building, measuring and managing brand equity. Saddle River, NJ: Prentice-Hall, 1998.

KERR, G. et al. An inside out approach to integrated marketing communication: an international analysis. International Journal of Advertising. v. 27, n. 4, p. 511-548, 2008.

KHERMOUCH, G.; GREEN, J. Buzz-z-z marketing. Business Week. n. 3743, p. 50-56, $30 / 7 / 2001$.

KIELY, M. Integrated marketing: starting out. Marketing. Australia, p. 44-46, April, 1993, apud KIM, I. et al. Understanding the diffusion of integrated marketing communications. Journal of Advertising Research. v. 44, n. 1, p. 31-45, 2004.

KIM, I. et al. Understanding the diffusion of integrated marketing communications. Journal of Advertising Research. v. 44, n. 1, p. 31-45, 2004.

KITCHEN, P. J.; PROCTOR, R. A. The increasing importance of public relations in fast moving consumer goods firms. Journal of Marketing Management. v. 7, n. 4, p. 357-370, October 1991.

KITCHEN, P. J.; SCHULTZ, D. E. Integrated corporation and product brand communication. Advances Competitiviness Research. v. 11, n. 1, p. 66, 2003.

KLAHR, S. Ace in the hole. Advertising Age's Creativity. v. 7, n. 7, p. 9, September 1999.

KLIATCHKO J. Towards a new definition of integrated marketing communications. International Journal of Advertising, v.24, n. 1, p.7-34, February 2005.

Revisiting the IMC construct: a revised definition and four pillars. International Journal of Advertising. v. 27, n. 1, p. 133-160, 2008.

20 years after: a second look at IMC definitions. International Journal of Integrated Marketing Communications. v. 1, n. 2, p. 7-12, fall 2009. 
KNIGHT, C. M. Viral marketing. Boardwatch Magazine. v. 13, 1999.

KOHLI, A.; JAWORSKI, B. Market orientation: the construct, research propositions, and managerial implications. Journal of Marketing. v. 54, n. 2, p. 1-18, October 1990.

KOHLI, A. et al. MARKOR: a measure of market orientation. Journal of Marketing Research. v. 30, p. 467-477, 1993.

KOKKINAKI, F.; AMBLER, T. Marketing performance assessment: current practice and the role of firm orientation, Pan'Angra Working Paper, 98-902, Centre for Marketing, London Business School. January 1999.

KOTLER, P.; KELLER K. L. Administração de marketing. 12. ed. São Paulo: Pearson Education do Brasil, 2006.

KOTLER, P.; MINDAK, W. Marketing and public relations. Journal of Marketing. v. 42, n. 4, p. 13-20, October 1978.

KOTLER et al. Principles of Marketing. $2^{\text {nd }}$ European edition. New Jersey: PrenticeHall. 1999.

KUMAR, V. et al. How valuable is word of mouth? Harvard Business Review. v. 85, Issue 10, p. 139-146, Oct. 2007.

LAKATOS, E. M.; MARCONI, M. A. Metodologia científica. São Paulo: Atlas, 1989.

LAS CASAS, Alexandre Luzzi (Org.). Marketing bancário. São Paulo: Saint Paul, 2007.

LAVIDGE, R. J.; STEINER, G. A. A model for predictive measurements of advertising effectiveness. Journal of Marketing. v. 25, n. 6, p. 59-62, 1961.

LAWRENCE, L. et al. A method for the selection of appropriate business-to-business integrated marketing communications mixes. Journal of Marketing Communications. v. 8, p. 1-17, 2002.

LENSKOLD, J. D. Marketing ROI: the path to campaign, customer, and corporate profitability. New York: McGraw-Hill, 2003.

LIMEIRA, T. M. Administração das Comunicações de Marketing. In DIAS; S. R. (Org.). Professores do Departamento de Mercadologia da FGV - EAESP e Convidados. Gestão de marketing. São Paulo: Saraiva, 2005.

LINDENMANN, W. K. An effectiveness yardstick to measure public relations success. Public Relations Quarterly. v. 38, n. 1, p.7-10, spring 1993.

LODA, M. et al. Sequence matters: a more effective way to use advertising and publicity. Journal of Advertising Research. v. 45, Issue 4, p. 362-372, Dec. 2005. 
LOSHIN, D. Developing information quality metrics. DM Review. v. 15, n. 5, p. 24-27, May 2005.

MADDOX, K. Measurement calls for more resources. B to B. v. 91, n. 4, p. 1-69, 3/4/2006a.

Assessing DVRs' impact on TV ads. B to B. v. 91, n. 4, p.16-16, 3/4/2006b.

MALHOTRA, K. N. Pesquisa de marketing: uma orientação aplicada. 3. ed. Porto Alegre: Bookman. 2006.

MATTAR, F. N. Pesquisa de marketing. 4. ed. São Paulo: Atlas, 2008.

MARCONI, M. de A.; LAKATOS, E. M. Fundamentos de metodologia científica. 7. ed. São Paulo: Atlas, 2010.

MARTENSEN, A. et al. Application of a model for the effectiveness of event marketing. Journal of Advertising Research. v. 47, Issue 3. 47, n. 3, p. 283-301, Sep. 2007.

MARTINS, R. Facebook ultrapassa Orkut em usuários no BR. 04/09/2011.Disponível em: http://blogs.estadao.com.br/rodrigo-martins/2011/09/04/facebook-ultrapassa-orkutem-usuarios-e-acaba-com-reinado-de-7-anos-no-br/.>. Acesso em 8/01/2012.

MATHES, J. So you've managed to generate branch traffic - now what? American Banker. v. 169, n. 20, 30/1/2004

McCARTHY, E. J. Basic marketing: a managerial approach. Homewwod, IL: Richard Irwin, 1960.

McDONALD, M.; MOUNCEY, P. Marketing de resultados: como medir e analisar a efetividade do marketing em sua organização. Rio de Janeiro: Elsevier, 2011.

McDONALD, M. et al. Key Account management: theory, practice and challenges. Journal of Marketing Management. v. 13, n. 8, p. 737-757, November 1997.

McKENNA, R. Marketing de relacionamento: estratégias bem-sucedidas para a era do cliente. Rio de Janeiro: Campus, 1993.

MEENAGHAN, T. Current developments and future directions in sponsorship. International Journal of Advertising. v. 17, p. 3-28, 1998.

Commercial sponsorship: the development of understanding. International Journal of Sports Marketing \& Sponsorship. v.1, n. 1, p. 19-31, 1999.

MILLER, R. K.; WASHINGTON, K. Direct Marketing. In MILLER, Richard K.; WASHINGTON, Kelli. Consumer behavior. Atlanta: Richard K. Miller \& Associates, 2011. Chapter 62, p. 350-353.

MILOSKI, W. Marketing's neo-renaissance: an opportunity for tomorrow's multichannel integrated marketer. Journal of integrated marketing communications. 2005. 
MINISTÉRIO DA CULTURA. Mecenato maiores incentivadores 2007 e 2008. [2011]. Disponível em: $<$ http://www.cultura.gov.br/site/?s=s\&cx=015263130529786204654\%3Aasoduglh86s\& cof=FORID\%3A11\&q=incetivadores+\&sa=\#1650 > Acesso em: 17/08/2011.

MINISTÉRIO DA FAZENDA. Economia Brasileira em perspectiva. Edição Especial ano 2010. Disponível em < http://www.fazenda.gov.br/portugues/docs/perspectivaeconomia-brasileira/edicoes/Economia-Brasileira-Em-Perpectiva-Especial-10.pdf > .

Acesso em: 22/11/2011.

MIR, I .Consumer attitude towards M-advertising acceptance: a cross-sectional study. Journal of Internet Banking \& Commerce. v. 16, n. 1, p. 1-22, April 2011.

MISMETTI, D. Ah, como era gostoso o meu leitinho. Folha de S.Paulo. 08/11/2008. Disponível em: 〈http://www1.folha.uol.com.br/fsp/vitrine/vi0811200807.htm>. Acesso em: 10/09/2011.

MIYAZAKI, A.; MORGAN, A. Assessing market value of event sponsoring: corporate Olympic sponsorships. Journal of Advertising Research. v. 41, n. 1, p. 9-15, 2001.

MOTTA, R. et al. Trade marketing: teoria e prática para gerenciar os canais de distribuição. Rio de Janeiro: Elsevier, 2008.

MOWEN, J. C., MINOR, M. S. Comportamento do consumidor. São Paulo: Prentice Hall, 2003.

MSI - Marketing Science Institute. Disponível em: < http://www.msi.org/research/index.cfm?id=43 >. Acesso em: 20/03/2010.

NAIK, P.; RAMAN, K. Understanding the impact of synergy in multimedia communications. Journal of Marketing Research. v. 40, n. 4, p. 375-388, November 2003.

NARVER, J.; SLATER, S. The effect of a market orientation on business profitability. Journal of Marketing. v. 54, n. 4, p. 20-35, 1990.

NEELY, A. D. Business performance measurement: theory and practice. Cambridge: Cambridge University Press, 2002.

NIEDERHOFFER, K. et al. The origin and impact of CPG new-product buzz: emerging trends and implications. Journal of Advertising Research. v. 47, n. 4, p. 420-426, December 2007.

NIELSEN BUZZ METRICS. Disponível em: < http://www.nielsenonline.com/products_buzz.jsp?section=pro_buzz>. Acesso em: 10/10/2011.

NUNES, P.; MERRIHUE, J. The continuing power of mass advertising. MIT Sloan Management Review. v. 48, n. 2, winter 2007. 
O'CASS, A. GRACE, D. Service brands and communication effects. Journal of Marketing Communications, v. 10, n. 4, p. 241-254, December 2004.

OGDEN, J.; CRESCITELLI, E. Comunicação integrada de marketing: conceitos, técnicas e práticas. 2. ed. São Paulo: Pearson Prentice Hall, 2007.

OZTURK, M. et al. Impact of sponsorship on companies that supported the 2002 Salt Lake City Winter Paralympics. International Journal of Sports Marketing \& Sponsorship. v. 5, n. 4, p. 282-295, March 2004.

PEPPERS, D., ROGERS, M. The one to one future: building relationships one customer at a time. New York: Currency Doubleday, 1997.

PERLOFF, R. M. The dynamics of persuasion. Hillside, NJ: Lawrence Erlbaum Associates, 1993 apud LODA, M. D.; COLEMAN, B. C. Sequence matters: a more effective way to use advertising and publicity. Journal of Advertising Research. v. 45, n. 4, p. 362-372, December 2005.

PHELPS, J. E. et al. Viral marketing or electronic word-of-mouth advertising: examining consumer responses and motivations to pass along email. Journal of Advertising Research. v. 44, n. 4, December 2004.

PHILLIPS, J. J et al. O valor estratégico dos eventos: como e por que medir ROI. São Paulo: Aleph, 2008.

POPAI - Point-Of-Purchase Advertising International. 2011. Disponível em: <www.popaibrasil.com.br/biblioteca/arquivos/o_que_e_o_merchandising.pdf >. Acesso em: 22/07/2011.

POWELL, G. R. Return on marketing investment: demand more from your marketing and sales investments. Atlanta: RPI Press, 2002.

PRICE, M. Using Facebook to measure marketing. ABA Bank Marketing. v. 43, n. 5, p. 26-29, June 2010.

QUELCH, J. A.; CANNON-BONVENTRE, K. Better marketing at the point of purchase. Harvard Business Review. v. 61, n. 6, p. 162-169, November/December 1983.

QUEIROZ, M. J. Métricas de desempenho em marketing em empresas brasileiras. São Paulo, 2008. Tese (Doutorado) - Programa de Pós-Graduação da Faculdade de Economia, Administração e Contabilidade da Universidade de São Paulo.

REICHHELD, F. F. Loyalty-based management. Harvard Business Review. v. 71, n. 2, p. 64-73, March 1993.

The one number you need to grow. Harvard Business Review. v. 81, n. 12, p. 46-54, 2003.

RICHARDSON, R. J. et al. Pesquisa social: métodos e técnicas. 3. ed. São Paulo: Atlas, 2008. 
RIES, A.; TROUT, J. Positioning: the battle for you mind. New York: McGraw-Hill, 2001.

ROSENWALD, P. J. Accountable marketing: otimizando resultados dos investimentos em marketing. São Paulo: Pioneira Thomson Learning, 2005.

ROCHA, T. et al. O marketing de relacionamento e a construção da fidelidade do cliente. Um estudo de caso em uma empresa brasileira de seguros. In: SEMINÁRIOS EM ADMINISTRAÇÃO - SemeAD, VII; 2004, São Paulo. Anais... São Paulo: FEA/USP, 2004.

RUSSELL, C. A. Investigating the effectiveness of poduct placements in television shows: the role of modality and plot connection congruence on band memory and attitude. Journal of Consumer Research. v. 29, n. 3, p. 306-318, December 2002.

RUSSELL, C. A.; STERN, B. B. Consumers, characters, and products. Journal of Advertising. v. 35, n. 1, p. 7-21, 2006.

RUST, R. et al. O valor do cliente: o modelo que está reformulando a estratégia corporativa. Porto Alegre: Bookman, 2002.

SAMPIERI, R. H et al. Metodologia de pesquisa. 3. ed. São Paulo: McGraw-Hill, 2006.

SANTANDER.

Disponível

em:

<http://www.santander.com.br/portal/wps/script/templates/GCMRequest.do?page $=6140$ \&utm_source $=$ google\&utm_medium $=$ cpc\&utm term $=$ Santander\&utm campaign=bran ding\&gclid=CMXx-8WdyK0CFUOQ7Qod1D-SjA > . Acesso em: 21/08/2011.

SARGEANT, A.; WEST, D. C. Creative briefing. Direct \& Interactive Marketing. v. 8, p. 299-333, 2001.

SCHMITT, B. H. Experiential marketing. New York: The Free Press, 1999.

SCHULAKA, C. Looking for leads? Try these marketing methods. Practice Management Solutions. p. 8-9, May/June 2010.

SCHULTZ, D. E. et al. The new marketing paradigm: integrated marketing communications. Illinois: NTC Business Books, 1993.

SCHULTZ, D. E.; BARNES, B. Campanhas estratégicas de comunicação de marca. Rio de Janeiro: Qualitymark, 2001.

SCHULTZ, D. E.; SCHULTZ, H. F. IMC the next generation: five steps for delivering value and measuring returns using marketing communication. New York: McGrawHill, 2003.

SCHULTZ, D. E. Two profs prove real value of media integration. Marketing News. v. 38 , n. 1, p.6-7, Jan/15/2004a. 
SCHULTZ, D. E. Marcom metrics require a much more holistic methodology. Marketing News. v. 38, n. 7, April 15 2004b.

SENNA, P.V. Meu caro anúncio. São Paulo: Saraiva, 2003.

SELLTIZ, C. et al. Métodos de pesquisa de relações sociais. São Paulo: EPU, 1975.

SEVIN, C. H. Marketing productivity analysis. New York: McGraw-Hill, 1965 apud CLARK, B. Marketing performance measure history and interrelationship. Journal of Marketing Management. v. 15, p. 711-732, 1999.

SHAW, R., MAZUR, L. Marketing accountability: improving business performance. London: Financial Times, Retail and Consumer Publishing, 1997.

SHETH, J. N.; SISODIA, R. S. Feeling the heat-part I. Marketing Management. v. 4, n 2, p. 9-23, fall 1995.

SHIELDS, R. Orange finds tablets are cannibalising TV consumption. Advertising Age. 2011. Disponível em: <http://www.nma.co.uk/news/orange-finds-tablets-arecannibalising-tv-consumption/3032289. article>. Acesso em: 02/12/2011.

SHIMP, T. A. Propaganda e promoção. 5. ed. Porto Alegre: Bookman, 2002.

SLATER, S.; NARVER, J. Market orientation, customer value, and superior performance. Business Horizons. v. 37, Issue 2, p. 22-28, Mar./Apr. 1994.

Market orientation and the learning organization. Journal of Marketing. v. 59, Issue 3, p. 63-74, July 1995.

SMITH, B. G. Beyond promotion: conceptualizing public relations in integrated marketing communications. International Journal of Integrated Marketing Communications. v. 2, n 1, p. 47-57, spring 2010.

SMOLIANOV, P.; SHILBURY, D. Examining integrated advertising and sponsorship in corporate marketing through televised sport. Sport Marketing Quarterly. v. 14, Issue 4, p. 239-250, 2005.

SNOAD,L. Breaking into Brazil. MarketingWeek. 9 February 2012. Disponível em: $<$ http://www.marketingweek.co.uk/3033886.article?cmpid=MWE07\&cmptype=newslet ter\&ern=E168B1F52BD79718320DCE04D52BE420\&email=true>. Acesso em: 09/02/2012.

SOLOMON, M. R. O comportamento do consumidor: comprando, possuindo e sendo. $7^{\text {a }}$ edição, Porto Alegre: Bookman, 2008.

SPONSORMAP. 2011. Disponível em: 〈http://www.sponsormap.com/about/>. Acesso em: $15 / 07 / 2011$.

SRINIVASAN, S. et al. Mind-set metrics in market response models: an integrative approach. Journal of Marketing Research. v. 47, p. 672-684, August 2010. 
SRINIVASAN, S.; HANSSENS, D. M. Marketing and firm value: metrics, methods, findings, and future directions. Journal of Marketing Research. v. 46, n. 3, p. 293$312,2009$.

STERN, C.; STALK JR., G. Estratégia em perspectiva: the Boston Consulting Group. Rio de Janeiro: Campus, 2002.

STEWART, D.; PAVLOU, P. A. From consumer response to active consumer: measuring the effectiveness of interactive media. Journal of the Academy of Marketing Science. v. 30, Issue 4, p. 376-396, fall 2002.

STOTLAR, D. Sponsorship in North America: a survey of sport executives. Artigo apresentado na IV Conferência Anual da Associação de Gestão de Esportes da Austrália e New Zealand, Gold Coast, Australia, 1998.

SUN T. et al. Online Word-of-Mouth (or Mouse): An exploration of Its Antecedentes and Consequences, Journal of Computer-Mediated Communication, v.11, n.4, 2006.

SURMANEK, J. Media planning: a practical guide. 3rd Edition. Illinois: NTC Business Books, 1995.

TAO, S. et al. Online word-of-mouse: an exploration $f$ its antecedents and consequences. American Academy of Advertising Conference Proceedings. p. 27, 2005.

TARGET GROUP INDEX BRASIL. Mídia. Ago2010-Jan. 2011.

TAYLOR, C. P. Psst! How do you measure buzz? Adweek. v. 46, n. 41, p. 26-28, Oct. 2005.

TEDLOW, R. S. Keeping the corporate image: public relations and business, 19001950. Greenwich, CT: JAI Press, 1979.

THE ECONOMIST. Product placement: lights, camera, brands. October, 29, 2005, 81. Disponível em; <http://www.economist.com/node/5088577>. Acesso em: 15/09/2011.

THE SOUND OF MUSIC - CENTRAL STATION ANTWERP. 2011. Disponível em <http://www.youtube.com/watch?v=7EYAUazLI9k>. Acesso em: 20/06/2011.

TINBERGEN, J. Econometrics. Philadelphia: The Blakiston Company, 1951 apud CLARK, L.; DIRKSEN, C. J., Journal of Marketing. v. 16, n. 2, October 1951.

TOFFLER, B.; IMBER, J. Dictionary of marketing terms. New York: Barron's Education Series. 1994.

TOLEDO, G. L. Marketing bancário: análise, planejamento, processo decisório. São Paulo: Atlas, 1978.

THOMASCH, P. Product placement spending seen up 30\% in '07. Reuters. Mar. 14, 2007. Disponível em: <http://uk.reuters.com/article/2007/03/14/advertising-placementidUKN1429868020070314>. Acesso em: 25/09/2011. 
TSAI, M. et al. The effects of subliminal advertising on consumer attitudes and buying intentions. International Journal of Management. v. 24, n. 1, p. 3-14, March 2007.

UNCLES, M. Marketing metrics: a can of worms or the path to enlightenment? Journal of Brand Management. [S. 1.], v. 12, n. 6, p. 412-418, August 2005.

VALLES, M. S. Técnicas cualitativas de investigación social: reflexión metodológica y prática professonal. Madrid: Sintesis, 1997. apud GODOI, C. K.; MATTOS, P. L. C. L. Entrevista qualitativa: instrumento de pesquisa e evento diálogo. In GODOI, C. K.; BANDEIRA-DE-MELLO, R.; SILVA, A. B. (Org.). Pesquisa qualitativa em estudos organizacionais: paradigmas, estratégias e métodos. São Paulo: Saraiva, 2006.

VAN HEERDE, H. J. et al. Decomposing the sales promotion bump with store data, Marketing Science. v. 23, n. 3, p. 317-334, summer 2004.

VAN REIJMERSDAL, E. A. Brand placement prominence: good for memory! Bad for attitudes? Journal of Advertising Research. p. 151-153, June 2009.

VAVRA, T. G. Marketing de relacionamento: aftermarketing. São Paulo: Atlas, 1993.

VENKATRAMAN, N.; RAMANUJAM, V. Measurement of business performance in strategy research: a comparison of approaches. Academy of Management Review. v. 11, n. 4, p. 801-814, 1986.

VRANICA, S. Getting buzz marketers to fess up. The Wall Street Journal. p. B9, 2005.

WEBSTER, F. E. Rediscovering the marketing concept. Business Horizons. v. 31, p. 29-39, May/June 1988.

WILLIAMS et al. Product placement effectiveness: revisited and renewed. Journal Of Management \& Marketing Research, v. 7, p. 1-24, march 2011.

WILSON, J. et al. How valuable is word of mouth? Harvard Business Review. v. 85, n.7/8, p. 23-25, July/August 2011.

WOHLFEIL, M.; WHELAN, S. Consumer motivations to participate in eventmarketing strategies. Journal of Marketing Management. v. 22, n. 5/6, p. 643-669, July 2006.

WOLD, H.; JUREEN, L. Demand analysis: a study in econometrics. New York: John Wiley \& Sons 1953 apud BOSCHAN, P. Demand analysis: a study in econometrics. Journal of Marketing. v. 18, n. 2, p. 211-212, October 1953.

WOMMA - Word of Mouth Marketing Association. Disponível em < http://womma.org/main/>. Acesso em 03/08/2011.

WOTRUBA, T. R. The evolution of personal selling. Journal of Personal Selling \& Sales Management. v. 11, n. 3, p.1-13, summer 1991. 
YIN, R. K. Estudo de caso: planejamentos e métodos. 3. ed. Porto Alegre: Bookman, 2005.

YOUTUBE. 2011. Disponível em: <http://www.youtube.com/watch?v=X3yGSJE53kU>. Acesso : 3/12/2011.

ZEITHAML, V. A. Service quality, profitability and the economic worth of customers: what we know and what we need to learn. Journal of the Academy of Marketing Science. v. 28, n. 1, p. 67-85, 2000.

ZEITHAML, V.; BITNER, M. J. Marketing de serviços: a empresa com foco no cliente.2. ed. Porto Alegre: Bookman, 2003

ZIGMOND, D.; STIPP, H. Assessing a new advertising effect. Journal of Advertising Research, v. 50, n. 2, p. 162-168, June 2010. 


\title{
APÊNDICES
}

\section{APÊNDICE 1 - ROTEIRO DE ENTREVISTA}

\section{Roteiro de Entrevista}

\author{
i) Empresa: \\ ii) Nome do entrevistado(a): \\ iii) Cargo: \\ iv) Envolvimento com decisões de comunicação de marketing \\ v) Qual o objeto da comunicação de marketing em que está envolvido(a) - produto, \\ institucional. Se produto, qual(is) produto(s)?
}

\section{Ações Offline}

1) Quais são as ações de comunicação offline adotadas pelo banco?

2) Quais as ações de comunicação offline mais significativas ?

3) O banco avalia os resultados destas ações de comunicação offline?

4) Caso afirmativo, de quais destas ações de comunicação offline o banco avalia os resultados?

5) Como o banco avalia os resultados?

6) Se o banco não avalia os resultados, sabe dizer os motivos?

7) Há outras áreas e/ou profissionais envolvidos em comunicação offline? Caso afirmativo, em qual ação de comunicação offline estão envolvidos? Poderia indicar áreas e pessoas responsáveis por estas ações e contato?

8) Sabe responder se o banco avalia os resultados das demais ações de comunicação offline e como avalia?

9) Se o banco não avalia as demais ações de comunicação offline, sabe dizer por quê?

\section{Ações online}

10) Quais são as ações de comunicação online adotadas pelo banco?

11) Quais as ações de comunicação online mais significativas ?

12) O banco avalia os resultados destas ações de comunicação online?

13) Caso afirmativo, de quais destas ações de comunicação online o banco avalia os resultados?

14) Como o banco avalia os resultados destas ações de comunicação online? 
15) Se o banco não avalia os resultados, sabe dizer os motivos?

16) Há outras áreas e/ou profissionais envolvidos em comunicação online? Caso afirmativo, em qual ação de comunicação online estão envolvidos? Poderia indicar áreas e pessoas responsáveis por estas ações e contato?

17) Sabe responder se o banco avalia os resultados das demais ações de comunicação online e como avalia?

18) Se o banco não avalia as demais ações de comunicação online, sabe dizer por quê?

\section{Comparação}

19) A empresa compara os resultados de comunicação offline com comunicação online?

20) Caso afirmativo, como a empresa compara os resultados de comunicação offline com comunicação online?

21) $\mathrm{O}(\mathrm{A}) \mathrm{Sr}$ (a) tem alguma informação adicional ? 


\section{ANEXOS}

ANEXO 1 - 50 maiores instituições financeiras

ANEXO 2 - E-mail enviado para instituições 
ANEXO 1 - 50 maiores instituições financeiras

\begin{tabular}{|c|c|c|c|c|c|c|c|c|c|c|}
\hline & Instituiçöes & UF & Ativo total & $\begin{array}{c}\text { Ativo total (-) } \\
\text { intermediaçäo }\end{array}$ & $\begin{array}{c}\text { Depósito } \\
\text { total }\end{array}$ & $\begin{array}{c}\text { Patrimônio } \\
\text { liquido }\end{array}$ & $\begin{array}{l}\text { Lucro } \\
\text { líquido }\end{array}$ & $\begin{array}{c}\text { № de } \\
\text { agēncias }\end{array}$ & $\begin{array}{c}\text { Índice } \\
\text { de } \\
\text { Basikéia }\end{array}$ & $\begin{array}{c}\text { Índice de } \\
\text { imobilizas } \\
\text { äo }\end{array}$ \\
\hline 1 & BB & DF & 831.673.963 & 710.279.009 & 381.774.354 & 52.172.758 & 2.932.363 & 5.104 & 14,77 & 20,94 \\
\hline 2 & ITAU & SP & 750.525 .684 & 706.759 .868 & 218.286.318 & 64.785 .435 & 3.539 .423 & 3.780 & 16,11 & 37,85 \\
\hline 3 & BRADESCO & SP & 599.228.137 & 548.242 .993 & 204.711.972 & 51.477 .497 & 2.706 .930 & 3.659 & 15,33 & 47,74 \\
\hline 4 & BNDES & RJ & 538.114.697 & 538.114.697 & 21.217.682 & 75.602 .020 & 2.188 .930 & 1 & 23,55 & 0,34 \\
\hline 5 & CEF & DF & 432.165.196 & 402.546 .011 & 227.673.297 & 17.483.150 & 812.446 & 2.220 & 15,21 & 16,61 \\
\hline 6 & SANTANDER & SP & 391.388.905 & 387.878.907 & 119.721_.581 & 65.663.447 & 1.029 .050 & 2.408 & 28,9 & 38,58 \\
\hline 7 & HSBC & PR & 137.796.360 & 137.056 .045 & 73.744.275 & 7.960 .525 & $\mathbf{3 3 0 . 2 7 5}$ & 867 & 12,53 & 41,23 \\
\hline 8 & VOTORANTIM & SP & 115.568.061 & 107.365.511 & 24.945.282 & 8.678.627 & 384.979 & 34 & 12,45 & 1,57 \\
\hline 9 & SAFRA & SP & 77.199.212 & 68.910 .372 & 14.088 .339 & 5.858.934 & 238.061 & 102 & 16,08 & 21,16 \\
\hline 10 & CITIBANK & SP & 55.461 .045 & 55.461.045 & 15.697 .899 & 5.915 .895 & 100.935 & 128 & 12,17 & 14,83 \\
\hline 11 & BTG PACTUAL & RJ & 46.124.072 & 31.496 .630 & 10.829 .650 & 5.600 .882 & 208.289 & 5 & 17,73 & 10,7 \\
\hline 12 & BANRISUL & RS & 33.167.251 & 33.167.251 & 19.303.991 & 4.009 .935 & 211.335 & 439 & 15,4 & 7,69 \\
\hline 13 & DEUTSCHE & SP & 29.130 .605 & 28.553 .643 & 2.743 .024 & 968.273 & -22.274 & 2 & 13,23 & 2,67 \\
\hline 14 & CREDIT SUISSE & SP & 26.870 .021 & 26.066 .575 & 4.041.035 & 3.117_.391 & 135.148 & 2 & 16,36 & 12,86 \\
\hline 15 & BNB & CE & 24.708.141 & 24.671.980 & 8.720 .610 & 2.268 .750 & 75.685 & 186 & 17,64 & 4,23 \\
\hline 16 & BNP PARIBAS & SP & 24.608.835 & 23.609 .007 & 5.452 .854 & 2.268 .321 & 53.744 & 11 & 20,6 & 16,09 \\
\hline 17 & VOLKSWAGEN & SP & 21.220 .512 & 21.220 .512 & 6.233.989 & 1.942 .289 & 84.643 & 1 & 12,59 & 6,72 \\
\hline 18 & BIC & SP & 17.142.246 & 17.097 .385 & 8.899 .365 & 2.013 .629 & 83.236 & 37 & 15,64 & 2,96 \\
\hline 19 . & JP MORGAN CHASE & SP & 16.413.045 & 13.982 .030 & 336.415 & 1.706.217 & 44.803 & 6 & 19,49 & 3,67 \\
\hline 20 & BANSICREDI & RS & 13.898 .690 & 9.514.055 & 6.652 .480 & 316.471 & 11.130 & 5 & 13,93 & 16,25 \\
\hline 21 & PANAMERICANO & SP & 13.439.311 & 13.439 .311 & 5.028 .390 & 1.586 .568 & 78.726 & $\mathbf{1}$ & 13,45 & 7,92 \\
\hline 22 & SOCIETE GENERALE & SP & 13.370.157 & 13.370 .157 & 1.367 .440 & 1.057 .922 & -40.591 & 3 & 16,4 & 47,16 \\
\hline 23 & BMG & MG & 11.687.686 & 11.687 .369 & 5.754 .613 & 2.156.111 & 45.346 & 16 & 14,14 & 1,93 \\
\hline 24 & ALFA & SP & 11.355.338 & 10.836.033 & 1.960 .517 & 1.819.624 & 28.154 & 9 & 19,7 & 11,14 \\
\hline 25 & BANCOOB & DF & 11.354.798 & 10.667 .600 & 7.386 .062 & 296.643 & 12.076 & 8 & 12,66 & 18,82 \\
\hline 26 & FIBRA & SP & 9.979.571 & 9.950 .932 & 5.312 .131 & 875.830 & 1.138 & 14 & 13,01 & 25,1 \\
\hline 27 & ABC-BRASIL & SP & 9.821.381 & 9.821 .381 & 2.970 .683 & 1.384 .340 & 56.680 & 7 & 15,65 & 3,77 \\
\hline 28 & DAYCOVAL & SP & 9.780 .155 & 8.971.507 & 3.490_.949 & 1.791.180 & 43.426 & 32 & 18 & 9,61 \\
\hline 29 & CRUZEIRO DO SUL & SP & 9.676 .348 & 9.613.703 & 4.075 .027 & 1.151.134 & 41.030 & 6 & 18,89 & 7,14 \\
\hline 30 & MERCANTIL DO BRASI & MG & 9.676.237 & 8.832 .902 & 5.881 .672 & 727.937 & 13.199 & 155 & 12,98 & 14,82 \\
\hline 31 & BTMUB & SP & 9.628.149 & 9.536.178 & 456.043 & 377.159 & 1.485 & 2 & 25,25 & 1,54 \\
\hline 32 & PINE & SP & 9.415 .948 & 9.415.948 & 3.050 .394 & 878.549 & 31.450 & 8 & 17,12 & 1,81 \\
\hline 33 & RABOBANK & SP & 9.183.917 & 8.314.315 & 252.666 & 658.496 & 4.830 & 15 & 16,67 & 0,68 \\
\hline 34 & BANESTES & ES & 8.912.743 & 7.845 .778 & 5.361 .949 & 811.724 & 32.301 & 133 & 18,22 & 18,99 \\
\hline 35 & MERCEDES-BENZ & SP & 8.864.635 & 8.864 .635 & 45.299 & 1.045 .018 & 29.791 & 1 & 13,64 & 0,24 \\
\hline 36 & BASA & PA & 8.812.997 & 8.812 .997 & 2.338 .549 & 1.939 .848 & 5.870 & 111 & 22,01 & 4,92 \\
\hline 37 & MERRILL LYNCH & SP & 8.178.334 & 8.178.334 & 58.768 & 1.239 .381 & 42.223 & 1 & 35 & 1,15 \\
\hline 38 & BRDE & RS & 7.847.949 & 7.847.949 & 0 & 1.187.484 & 24.056 & 3 & 17,41 & 1,7 \\
\hline 39 & BRB & DF & 7.838 .800 & 7.513 .980 & 5.968 .687 & 772.381 & 48.746 & 62 & 16,23 & 13,7 \\
\hline 40 & BES & SP & 7.408.145 & 7.408 .145 & 2.207.191 & 480.465 & 3.943 & 0 & 12,83 & 22,83 \\
\hline 41 & BANCO GMAC & SP & 7.106.287 & 7.106.287 & 2.084 .415 & 1.192 .396 & 30.500 & 1 & 12,1 & 24,61 \\
\hline 42 & SOFISA & SP & 5.598 .390 & 5.598 .390 & 2.356.941 & 777.370 & 13.063 & 18 & 18,38 & 31,77 \\
\hline 43 & CLASSICO & RJ & 5.357.158 & 5.357 .158 & 117 & 4.010 .799 & 5.244 & 2 & 66,33 & \\
\hline 44 & BVA & $\mathbf{R J}$ & 5.233 .487 & 5.233 .487 & 3.435 .128 & 588.067 & 25.403 & 6 & 13,43 & 30,38 \\
\hline 45 & BARCLAYS & SP & 4.582.476 & 4.482 .876 & 606.997 & 724.550 & 29.332 & $\mathbf{1}$ & 50,49 & 2,47 \\
\hline 46 & FIDIS & MG & 4.462.276 & 4.462 .276 & 2.974.237 & 384.361 & 6.103 & 2 & 13,01 & 0,74 \\
\hline 47 & RURAL & MG & 4.420.799 & 4.420 .799 & 3.170 .399 & 447.286 & 1.637 & 28 & 12,27 & 20,18 \\
\hline 48 & INDUSVAL & SP & 4.346.871 & 3.859 .342 & 1.663 .190 & 563.731 & -54.464 & 10 & 23,68 & 2,22 \\
\hline 49 & LAGE LANDEN & RS & 4.305.385 & 4.305.385 & 70.062 & 461.659 & -35.584 & $\mathbf{1}$ & 13,42 & 0,61 \\
\hline 50 & MORGAN STANLEY & SP & 4.208.730 & 4.208 .730 & 1.125.868 & 1.356 .593 & 49.860 & 2 & 35,82 & 0,68 \\
\hline
\end{tabular}

Fonte: BACEN (2011) 
ANEXO 2 - E-mail enviado para instituições

Prezado xxxx,

Sou aluna do doutorado em Administração da USP. Estou concluindo minha tese cujo tema é "métricas de comunicação de marketing offline e online".

A amostra são bancos que invistam numa variedade de ações de comunicação offline e online. O objetivo é saber como os bancos medem os resultados dos investimentos em comunicação e se é feita uma comparação entre os resultados das ações offline e online.

Não serão solicitados valores investidos, nem resultados atingidos. As informações fornecidas serão analisadas conjuntamente, garantindo confidencialidade.

A entrevista é curta, em torno de 30 minutos e poderá ser feita pessoalmente ou por telefone, conforme conveniência do entrevistado.

Agradeço se puder ajudar-me na marcação desta entrevista com o diretor de marketing do XXXX.

Cordialmente,

Valéria Freundt 